Regina Egetenmeyer / Monica Fedeli (eds.)

\title{
Adult Education and Work Contexts: International Perspectives and Challenges
}

Comparative Perspectives from the 2017 Würzburg Winter School

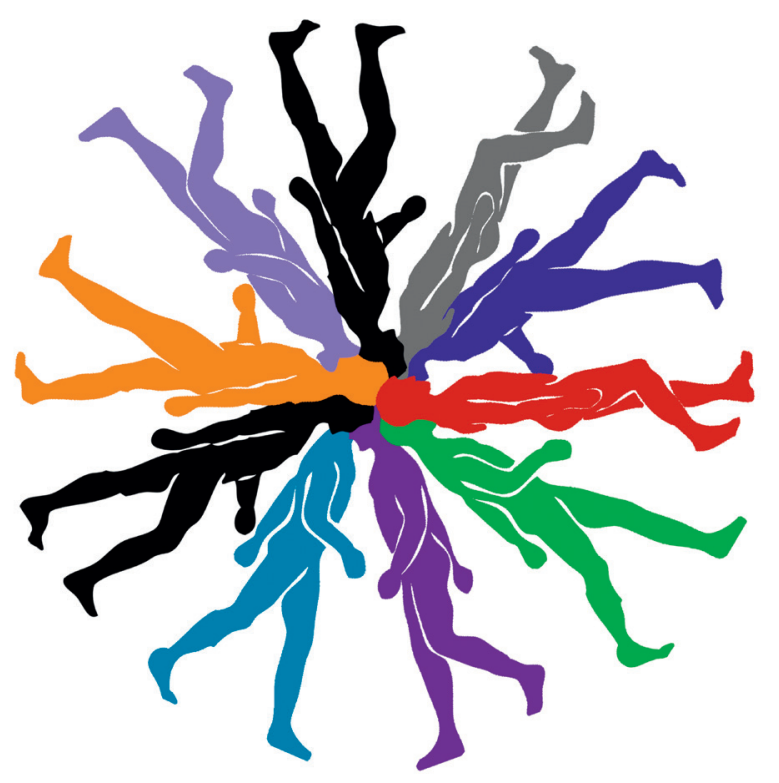


Regina Egetenmeyer / Monica Fedeli (eds.)

\section{Adult Education and Work Contexts: International Perspectives and Challenges}

Adult education has deep connections with employment contexts. This volume discusses interrelations within transnational contexts studied during the Würzburg Winter School on Comparative Studies in Adult Education and Lifelong Learning (COMPALL). The book shows that adult education and work contexts are influenced by international and transnational developments. The findings are presented in three chapters: Lifelong Learning Policies Targeting Employment Contexts; Transnational Perspectives on Lifelong Learning Policies; Employment Perspectives and Professionalisation in Adult Education.

\section{The Editors}

Regina Egetenmeyer is Professor of Adult and Continuing Education at the University of Würzburg/Germany.

Monica Fedeli is Associate Professor of Teaching and Learning Methods in Adult Education at the Università degli Studi di Padova/Italy. 
Adult Education and Work Contexts:

International Perspectives and Challenges 


\section{STUDIES IN PEDAGOGY, ANDRAGOGY AND GERONTAGOGY}

Founded by Franz Pöggeler

Edited by Bernd Käpplinger and Steffi Robak

VOLUME 72 
Regina Egetenmeyer / Monica Fedeli (eds.)

\section{Adult Education and Work Contexts: \\ International Perspectives and Challenges}

Comparative Perspectives from the 2017 Würzburg Winter School 


\section{Bibliographic Information published by the Deutsche Nationalbibliothek}

The Deutsche Nationalbibliothek lists this publication in the Deutsche Nationalbibliografie; detailed bibliographic data is available in the internet at http://dnb.d-nb.de.

\section{Library of Congress Cataloging-in-Publication Data}

A CIP catalog record for this book has been applied for at the Library of Congress.
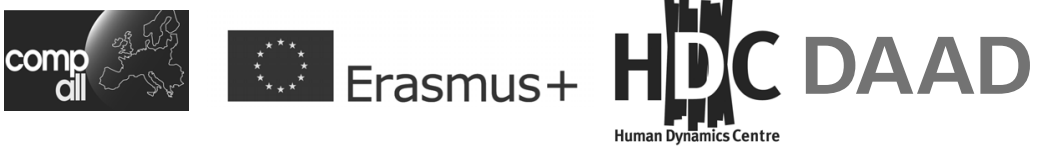

This project is funded with support from the European Commission within the ERASMUS+ Strategic Partnerships (project number: 2015-1-DE01-KA203-002203). This communication reflects the views only of the author, and the Commission cannot be held responsible for any use which may be made of the information contained therein.

Proofreading: Carsten Bösel (consult US)

Graphic at cover illustration: Dr. Andreas Rauh, Human Dynamics Centre

ISSN 0934-3695

ISBN 978-3-631-73702-6 (Print)

E-ISBN 978-3-631-73703-3 (E-PDF)

E-ISBN 978-3-631-73704-0 (EPUB)

E-ISBN 978-3-631-73705-7 (MOBI)

DOI $10.3726 / \mathrm{b} 12114$

\section{PETER LANG

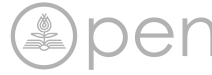

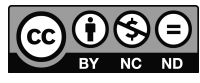

Open Access: This work is licensed under a Creative

Commons Attribution NonCommercial NoDerivatives 4.0 unported license.

To view a copy of this license, visit https://creativecommons.org/licenses/by-nc-nd/4.0/

(C) Peter Lang GmbH

Internationaler Verlag der Wissenschaften

Frankfurt am Main 2017

Peter Lang Edition is an Imprint of Peter Lang GmbH.

Peter Lang - Frankfurt am Main · Bern · Bruxelles · New York ·

Oxford $\cdot$ Warszawa $\cdot$ Wien

This publication has been peer reviewed. 


\section{Table of Contents}

Bernd Käpplinger \& Steffi Robak

Adult Education for work and beyond

Regina Egetenmeyer \& Monica Fedeli

Adult learning and employability: International research and practice

\section{Lifelong Learning Policies Targeting Employment Contexts}

Jan Schiller, Sabine Schmidt-Lauff \& Fabio Camilloni

Comparing temporal agendas of policies and institutions in

(work-related) adult education

Arunima Chauhan, Hyejin Bak, Shreelakshmi Subbaswamy \&

Vijay Kumar Dixit

Lifelong learning and skill development policies and programmes: A

comparison between India and South Korea

Shalini Singh, Leonardo Silveira \& Janiery da Silva Castro

Comparing the Continuing Vocational Education and Training

Policies of Italy, Brazil, and India: What could be compared

and what could not be compared, and why?

\section{Transnational Perspectives on Lifelong Learning Policies}

Reinhard Lechner, Mari Liis Räis, Nitish Anand,

Ahmet Murat Yetkin \& Paula Guimarães

The influence of PIAAC results on (inter-)national adult education policy:

A critical discussion of Austria and Estonia

Lisa Breitschwerdt \& Vicheth Sen

Implementing National Qualifications Frameworks:

Difficulties in Cambodia and Germany

Vanna Boffo, Azeez Babatunde Adebakin \& Carlo Terzaroli

Supporting entrepreneurship in higher education for young adults'

employability: A cross-border comparative study.... 


\section{Employment Perspectives and Professionalisation in Adult Education}

Christin Cieslak, Rute Ricardo, Jenny Fehrenbacher,

Bharti Praveen \& Kira Nierobisch

Between educating and teaching: The professional identity of adult

educators. A transnational comparison between Portugal,

India, and Germany

Gaia Gioli, Nicoletta Tomei, Ashok Kumar \& Sunita Sijwali

The development of employability skills in higher education curricula:

A transnational comparison

Robert Jjuuko, Zahia Alhallak \& Concetta Tino

Learning and work: Efficacy of university internships for syrian

and ugandan education students

Bolanle C. Simeon-Fayomi, Elizabeth A. Ajayi,

Nikola Koruga \& Geetanjali Baswani

Enhancing employability through innovative teaching methods in adult learning and education: A comparative study of Nigeria and India

Authors

Reviewers 


\section{Bernd Käpplinger \& Steffi Robak}

\section{Adult Education for work and beyond}

Adult education is often closely connected to processes of modernisation (Salling Olesen, 2014; Schrader, 2014). That is why it is also reasonable to explain adult education with the help of modernisation theories, although modernity is and must nowadays also be viewed critically, as modernisation often produces negative outcomes in many respects. The individual in particular might have the feeling of being lost in such big transitions and threatened by a loss of their identity. Economic development is often achieved at the cost of pollution and a lack of sustainability. The so-called first world is exporting production and pollution to the so-called third world. It would be naive to think of modernisation only in terms of improvement. Societies undergoing significant changes caused by technological, political, or social reasons have a greater need for adult education. People cannot be prepared for such changes solely by 'front-loading' in school and initial training. Who would have expected 20 years ago that the world would look the way it does now? There are huge limits and challenges in preparing for the unknown future. Education has to prepare for the unknown, and it has to have a wide scope beyond immediate needs, although the actions and decisions of political and economic leaders are often short-sighted.

It has become popular to perceive adult education within a framework of employability and related policies. Being flexible and able to adapt seems to be the only required ability. The lifelong learning agenda from cradle to grave has something offensive and oppressive. It is not by accident that many people feel resistance and annoyance when it comes to learning. Nobody is ready to learn everything all the time. Retraining can be highly stressful. Adult education researchers and practitioners in particular should be aware of that and think critically of employability policies with their implied ideal of flexible women and men. There is a rich tradition of such critical approaches in adult education, which are aware that learning is not something exclusively positive. There is awareness in the discipline that the individual is not always ready to learn and that this reluctance is often absolutely legitimate and has to be respected. Adults should be free to decide if they want to learn or not.

Thus, it is very helpful that this volume makes such intensive reference to policies. Scholars in adult education have to be aware of policies, because their work is highly influenced by them in many respects. At the same time, they have 
to look beyond such policies and think critically about whether such policies really give serious consideration to the individual or collective points of view of learners and professionals. In many countries, there is presently strong criticism that policy-makers focus not enough on the people and their situations. Adult education, with its traditional focus on learners, bottom-up movements, and enlightenment, could play a key role in promoting different views in contrast to human resources management theories and top-down policies. The multi-layered system of adult education (cf. Schrader, 2014) cannot be governed top-down. This is only assumed by governments and administrations that overestimate their own influence and power.

The potential of adult education research and practice in offering different perspectives is far from being explored yet. This also means relating to one root of adult education, namely that in the labour movement. Educated workers also have to learn how to influence and shape their working conditions in relation to their own needs and interests. Adapting to the supposed needs of governments or big businesses is not enough. It would mean to lose a lot of the creativity and resources of workers, who often know much better than administrations what is needed in order to improve work results. Work nowadays should be organised beyond Taylorism and Neo-Taylorism, although work is very different in different parts of the world despite globalisation. It is very interesting to study the comparative approaches presented in this book. This book and the connected international Würzburg Summer School is a highly recommendable activity, one that is truly comparative. It enables us to learn more about each other. The Danish scholar Henning Salling Olesen wrote in 2014 (p. 54): 'We may most productively see modernisation as an infinite process that is still dependent on human efforts and choices on individual, as well on global level.' Considering the world's present situation, it is important to remind us that we have to do something to avoid the end of modernisation by returning to oppressive neotribalist structures with their fraud and clientilism. Modernisation and democracy are no given, ever-lasting achievements but ongoing projects that require the global engagement and exchange of politicians, policy-makers, scholars, students, practitioners, and learners. This volume is a small but stimulating contribution to this endeavour.

\section{References}

Salling Olesen, Henning: "Adult Education in the Danish Modernisation Process". In: Käpplinger, Bernd / Robak, Steffi (eds.): Changing Configurations in 
Adult Education in Transitional Times. Peter Lang: Frankfurt a.M. et al. 2014, pp. 39-56.

Schrader, Josef: "Strategies of Modernisation and their Effects on Configurations of Adult Education”. In: Käpplinger, Bernd / Robak, Steffi (eds.): Changing Configurations in Adult Education in Transitional Times. Peter Lang: Frankfurt a.M. et al. 2014, pp. 57-72. 
Regina Egetenmeyer and Monica Fedeli - 978-3-631-73704-0

Downloaded from PubFactory at 01/11/2019 10:08:46AM

via free access 


\title{
Regina Egetenmeyer \& Monica Fedeli ${ }^{1}$
}

\section{Adult learning and employability: International research and practice}

\begin{abstract}
Adult education has deep connections with employment contexts. This chapter outlines interrelations within transnational contexts studied during the 2017 Winter School on Comparative Studies in Adult Education and Lifelong Learning (COMPALL). The paper shows that adult education and work contexts are influenced by international and transnational issues.
\end{abstract}

\section{Introduction}

Adult education and employment have long been understood as oppositional contexts in society. Whereas adult education seems to follow pedagogical principles designed to develop people according to their individual abilities and interests, employment contexts seem to primarily follow economic principles of profit maximisation. This dichotomy is quite difficult to uphold in today's heterogeneous societies, in which individual interests and lives are interdependent with various societal contexts. Whereas school education, in principle, offers pupils a protected space to develop away from real life for several years, adult education is traditionally much more embedded into 'real life' and people's Lebenswelt. Adult education offerings have shorter time perspectives (sometimes just a few hours), and there is often an immediate interest in transferring skills to life and work. Likewise, financial resources frequently show the need for making links. This is already evident in the first studies on adult education participation in Germany (Strzelewicz, Raapke, \& Schulenberg, 1966). Furthermore, employment contexts are rather diverse. The economic sector is not the only employment context. Public bodies and civil society also provide employment contexts (for adult education in Germany, see Autorengruppe wb-personalmonitor, 2017).

The chapters in this book focus on the interdependencies between adult learning and education on the one hand and employment contexts on the other. The internationally comparative focus of all papers shows how these interdependencies are interrelated with international developments and their transnational contexts. Employment contexts and employability are the focus of policies of international

1 The two authors have made equal contributions to this chapter. 
stakeholders (e.g. European Union, 2012; see chapters in this volume). Adult and continuing learning and education - besides other educational fields - seem to be understood as an activity promoting the employment opportunities of adults on the one hand and supporting the development of competences required by the employment market on the other hand. Adult and continuing learning and education are not only essential because of the ongoing development of technologies, innovations, and societies. They also become essential because of demographic developments. Education can no longer be understood under the perspective of a 'normal biography' (Kohli, 1985) - birth, education, and employment - as it was seen in several European countries. Moreover, individuals experience a range of options but also new pressure to develop their own life. Migration within and between countries and continents challenges people to adapt to new situations. Adult people migrating to find employment are faced with huge learning projects (Tough, 1971) when trying to adapt to the needs of the new employment contexts. But besides the perspectives on individuals and society at large, the contributions from India in this volume in particular show the political focus on skill development, which can be understood as a call from policy makers to adults to develop the skills needed by the economy.

From a transnational perspective, the papers in this volume analyse similarities and differences in adult education and their related developments. Besides all differences, the papers outline similarities in the terminology related to adult education and employment contexts: Terms such as skill development, soft skills, qualification framework, entrepreneurship, employability, and professional identity seem to be used in different international, national, and transnational contexts. The data in this volume only allow for formulating assumptions regarding these interdependencies, and one should be careful to identify an internationally implicit hegemonic development, as is frequently found in the 'soft law' discourse (Marcussen, 2004; Bieber \& Martens, 2011) concerning the role of international organisations. Political scientists stress that international organisations do not have policies of their own (Klatt, 2014). Moreover, the policies of international organisations represent the agreements of national governments and stakeholders. This means that organisations do not develop policies contradicting those of national governments, and neither do they act as superordinate bodies to national governments. But in contrast to national developments, the development of international policies seems to be less transparent and less accessible compared to national discourses. One may ask if international educational policies can be understood as being above national agreements, or if they represent an agreement of some powerful members of international organisations. The Bologna Process, 
as well as the comparative analysis of educational policies performed outside of the COMPALL Winter Schools (Egetenmeyer 2016; Egetenmeyer, Schmidt-Lauff, \& Boffo, 2017), indicate that international educational policies have an influence going way beyond member states. This can raise the question of an internationally hegemonic influence of international policies, but it can also raise the question whether international agreements are an expression of the cross-national developments indicated above. Maybe both developments reinforce each other and can even be analysed at the same time.

The contributions in this volume indicate that the employment contexts of university graduates in adult education are framed by international developments: National and international policies frame learning times (Schiller, Schmidt-Lauff, \& Camilloni, in this volume). National governments develop qualification frameworks targeting the development of transparency with respect to international concepts (Breitschwerdt \& Sen, in this volume). Results of the Programme for the International Assessment of Adult Competencies (PIAAC) serve as a reference for developments in national educational policies (Lechner et. al., in this volume). These few examples support the argument that the employment opportunities of people working in adult education are not only contextualized locally but also influenced by international developments. Besides these developments in the context of international policies, employment contexts in adult education have also become more international as a result of the internationalisation of societies and thereby through the international background of participants and through the development of an international market for continuing education (Egetenmeyer, forthcoming). This supports the argument that the employment contexts of university graduates in adult education are highly interwoven with international developments.

\section{Employment contexts from the perspective of comparative adult education}

The present volume is a result of the comparisons started by participants during the $4^{\text {th }}$ International Winter School on 'Comparative Studies in Adult Education and Lifelong Learning' ${ }^{2}$ at the University of Würzburg. Based on the experiences of the first two winter schools, a consortium of seven European partner universities is developing a joint module as part of the ERASMUS+ Strategic Partnership Comparative Studies in Adult Education and Lifelong Learning (COMPALL)

2 Cf. International Winter School homepage: www.lifelonglearning.uni-wuerzburg.de. 
(Egetenmeyer, Guimarães, \& Németh, forthcoming). The consortium includes the universities of Aarhus/Denmark, Florence/Italy, Lisbon/Portugal, Padua/Italy, Pécs/Hungary, Würzburg/Germany, and Helmut Schmidt University in Hamburg/ Germany. The COMPALL Winter School enrols international students from the partner universities. The 2017 programme brought together more than 90 participants from Europe, Asia, Africa, and America. Participation in the COMPALL Winter School is open to master's and doctoral students studying subjects linked to adult education and lifelong learning. In 2017, around half of the participants were doctoral students. They received the possibility to work further on the comparisons they started during the COMPALL Winter School and to publish a paper in this volume. All papers in this volume have successfully passed a peer review process supported by international experts in adult education.

The COMPALL Winter School is designed to promote the development of comparative adult education, which differs from comparative education (Egetenmeyer, 2016). For that reason, the comparative perspective is developed from the research interests of international experts in adult education. International experts in adult education serve as moderators in comparative groups composed of eight to ten students from three to five different countries. In preparation for the Winter School, the experts develop short reports in which they present their research interests for a comparative approach. To that end, they develop comparative research questions for the COMPALL Winter School comparative group work to pursue. The questions are linked to the contexts in which they are being researched. Transnational developments such as those found in adult education (see above) do not necessarily have countries as units of comparison, as it is often the case in comparative education research. Through its links to school systems, comparative education is linked much closer to national or regional structures. Adult education, by contrast, has much broader reference units than countries and/or regions. Adult education programmes offered by Catholic adult education providers in different countries may have more in common than adult education programmes offered by a Catholic adult education provider and a university-based continuing education centre in the same country or region. As a consequence, countries or regions are not the context of comparisons in all comparative groups; other units such as universities or cities also play a role. In this sense, international developments cannot always be attributed to national or regional policies or local contexts but also directly, without national intervention. By defining contexts for comparison, comparative cases studies are developed, which are prepared in advance in transnational essays by each participant of the comparative groups 
during the COMPALL Winter School. Each participant acts as a representative of his or her case and country.

Categories of comparison - called tertium comparationis in comparative education - do not form a starting frame of comparative research in adult education. Moreover, they have to be developed during the process of juxtaposition - the side-by-side placing of the selected cases (comparative units). The juxtaposition clearly shows which category is relevant for all cases and which can lead to a meaningful analysis of similarities and differences. The development of a meaningful tertium comparationis can be understood as an important result of comparative research in adult education. It creates a terminology for generating links between adult education in different countries. The tertium comparationis in adult education is called 'comparative categories' for the working process during the COMPALL Winter School. These categories are communication results for comparative research.

This argument should not restrict the call of Charters and Hilton (1989) to go beyond juxtaposition to work on the interpretation of the similarities and differences of phenomena in adult education. But it stresses the fact that the tertium comparationis is not deductively available in adult education, as frames of adult education differ from context to context. With this perspective, this volume is full of developed comparative categories which are analysed as meaningful in the research contexts. Several (but not all!) comparative categories are more connected to employment and policy contexts than to adult education: qualification frameworks, the influence of PIAAC results, entrepreneurship, or soft skills. The question arises whether categories outside of adult education may be more meaningful for the comparative analysis of adult education than adult education itself. Or whether they are simply easier to identify. The deep and dynamic adaptation of adult education to societal change may make adult education understandable only in its interrelations.

As in previous COMPALL Winter School publications, the authors experience the interpretation of their juxtaposition as the most challenging part of their comparisons: It is quite challenging to formulate assumptions on why similarities and differences occur in different contexts. A theoretical analysis may help to find arguments for similarities in particular (e.g. by globalisation theories, transnational theories, or policy analysis). Differences seem to be more difficult to understand and interpret. Therefore, the cases seem to need framing, and the question arises what is important for understanding the case (e.g. the reaction to PIAAC results in Estonia compared to reactions in Austria). The COMPALL consortium will 
further work on the development of the case framing for generating interpretation anchors for explaining the differences in adult education juxtapositions as well.

\section{Overview of the book}

With this perspective in mind, the book is divided into three chapters, which take into account specific interrelations between adult education and learning on the one hand and transnational contexts and employment on the other hand.

\section{Lifelong learning policies targeting employment contexts}

The first part provides three contributions analysing lifelong learning policies targeting employment contexts.

Schiller, Schmidt-Lauff, and Camilloni analyse temporal agendas in lifelong learning policies in Germany and Italy. The authors find diverse influences of national structures as well as international influences. Time for adult education is identified as a resource and an educational investment besides financial needs. Aside from all policy influences, the paper encourages readers to think about the general influence of the human resource management approach, which is present outside of national and international policies as well.

Chauha, Subbaswamy, Bak, and Dixit analyse lifelong learning and skill development policies and programmes in India and South Korea. The authors identify the countries' different approaches towards lifelong learning and skill development. These approaches are also highly influenced by differences in national employment contexts, the development of initial education, the different political organisations and systems, the differences in the size of the two countries, and the size of the population. The paper impressively shows how a seemingly subnational idea such as lifelong learning needs to be closely adapted to the diversity of contextual influences for realising lifelong learning.

Singh, Silveira, and da Silva Castro compare continuing vocational education and training policies in Italy, Brazil, and India and discuss the selection of units of comparison for comparative studies in scientific research. The authors identify the differences between the countries as comparable units and focus on two research questions. The first question concerns the way continuing vocational education and training policies are formulated in Italy, Brazil, and India, including primary influences on policies, actors, policy objectives, and target groups. The second question emerges from the first question and concerns the reasons for the formulation of continuing vocational education and training policies in Italy, Brazil, and India. Interesting implications and practices are discussed. 


\section{Transnational perspectives on lifelong learning policies}

In the second part, the authors analyse transnational perspectives on lifelong learning policies. Specifically, they analyse the reactions and interventions of national stakeholders in response to activities in the educational policies of international organisations.

Lechner, Räis, Anand, Yetkin, and Guimarães analyse the influence of PIAAC results on adult education policies in Austria and Estonia. Although the authors find an overall influence of human resource management guidelines in national policies, they also identify differences between the reactions in Austria and Estonia. These differences are tentatively explained by the different country contexts of Austria and Estonia (e.g. language needs, country/population size, geographical position in Europe).

Breitschwerdt and Sen analyse difficulties in the implementation of national qualification frameworks in Cambodia and Germany. To that end, the authors refer to Young's (2009) framework on challenges regarding the implementation of qualification frameworks. Aside from several similarities in the implementation, differences mainly refer to the political and educational structure in the two countries. These refer to historical developments, which are highly challenged by transnational and international qualification frameworks.

Terzaroli, Adebakin, and Boffo perform a comparative analysis of theoretical aspects and policy statements concerning entrepreneurship in the Italian and Nigerian higher education systems. The authors analyse the development of entrepreneurial education, concluding that both countries share common values. They therefore recommend making entrepreneurship one pillar of future university development. The analysis focuses on the best higher education models for the development of global citizens, taking into account the strategic challenge of work and employment.

\section{Employment perspectives and professionalisation in adult education}

Part three focuses on the interrelation between employment perspectives and professionalisation in adult education.

Cieslak, Ricardo, Fehrenbacher, Praveen, and Nierobisch present a comparative, transnational reflection on the main theories and concepts of academic professionalisation and the development of a professional identity, as an individual or as a profession. They provide an overview of the concepts and theories of professional identity, followed by a comparison of these concepts in India, Germany, and Portugal. Adult education in India is dominated by an endeavour to foster literacy and numeracy, whereas in the German academic context, professional development 
takes precedence. Portugal, however, emphasises the political and emancipatory aspects of adult education. The overview is followed by a transnational comparison of the different concepts and developments of professional identities in the three countries. Finally, the study presents the core dimensions of professional identity in adult education and points out potential issues to be tackled.

Gioli, Tomei, Kumar, and Sijwali compare the structure of the Italian and Indian master's degree curricula in education and the ways in which soft skills are developed during these programmes, creating a theoretical framework for comparison. The study shows how strategies and practices in higher education promote the employability and soft skills of young adults enrolled in master's degree courses in education in Italy and India. The authors also identify the most important soft skills for employability in the two countries and the ways in which master's degree curricula support the development of soft skills, for instance in courses, lectures, and workshops, or in an implicit or explicit way.

Jjuuko, Alhallak, and Tino analyse the relation between learning and work in educational studies in two universities in Syria and Uganda. For that purpose, they analyse the integration of internships in teacher education programmes at a university in Damascus and in adult education programmes in Kyambogo in Uganda. Although the academic programmes, employment contexts, and current situations in these two countries are very different, the authors find several similarities. The paper implicitly provides an insight into the expectations of two doctoral students towards their studies, which may differ from a European perspective. Universities are implicitly expected to provide close guidance in the search for internships, whereas European universities tend to put a stronger emphases on developing students' self-organisation skills.

Simeon-Fayomi, Ajayi, Koruga, and Baswani present a study based on the theory of andragogy, examining innovative teaching methods in adult education in Nigeria and India and presenting the life stories of ten adults. Based on their findings, the authors analyse different teaching methods in the two countries and conclude that innovative self-directed, experiential, and active strategies can be used in formal, non-formal, and informal contexts to promote employability in educational contexts.

\section{International employment context of graduates in adult education}

Whereas the analysis of the research perspectives in this volume provides insights to understand employment contexts as part of international and transnational developments, this can also be illustrated using the concrete employment situation 
of graduates of the COMPALL Winter School. As part of the ERASMUS+ Strategic Partnership and the COMPALL project, participants were asked about the impact of their participation 14 to 15 months after the Winter School. For that purpose, an external evaluation (mid-term evaluation) was done in collaboration with the German Institute for Adult Education (Lattke \& Egetenmeyer, not published). Within the limitations of an online survey (65 answers), the data show the high impact of participation concerning labour market entrance, networking activities, and academic perspectives.

Participants who were already employed at the time of the mid-term evaluation stress that their work involves international perspectives (around two-thirds), but even more (around 80\%) state that they are very motivated to engage with international issues in the future as part of their employment. This also includes cross-border mobility for employment purposes. That is why they think it is crucial to understand 'adult and lifelong learning in adult education', to which they think their participating in the COMPALL Winter School has made a strong contribution. The most highly valued competencies are interacting with people from a different cultural background, which the Winter School has also supported tremendously, according to participants. Further contributions are seen in the development of comparative research methods, which participants also view as highly valuable in their career perspectives.

Whereas these perspectives seem to be standard in other disciplines (Alves \& Guimarães, forthcoming), they have to be understood as very new perspectives for students and graduates in adult education. Adult education is typically a very national discipline. In study programmes at German universities, international and/or comparative perspectives on adult education frequently seem to be discussed only in single lectures or seminars. This means that the COMPALL Winter School closes a gap in academic adult education offerings in Europe: It integrates international and comparative perspectives in a broad way into adult education studies. One result of the Winter School is that participants feel integrated into an international network of adult education professionals and that they have the impression that they can contact several people in the field.

The mid-term evaluation also seems to indicate that the COMPALL Winter School has an impact on participants' academic perspectives. Around two-thirds of the participants included or will include international perspectives in their master's or doctoral thesis. Several of these projects involve travel abroad. Participants who did not include international perspectives because they already have a concrete plan or offer for their thesis argue the same way. According to participants, the highest value of including an international perspective in their 
thesis is gaining a more differentiated view on their own topic but also encouraging others to adopt an internationally comparative perspective.

\section{Conclusion and acknowledgments}

The results of this volume are based on strong collaboration with international researchers in adult education. Researchers in adult education designed comparative working groups, guided participants in the preparation of transnational essays, served as moderators in the comparative groups, and supervised the writing process of doctoral students preparing articles for this volume. Thank you very much to all moderators of the comparative groups: Prof Natalia Alves (University of Lisbon), Prof Vanna Boffo (University of Florence), Dr Tino Concetta (University of Padua), Prof Soeren Ehlers (Aarhus University), Prof Monica Fedeli (University of Padua), Dr Daniel Frison (University of Padua), Dr Gaia Gioli (University of Florence), Prof Paula Guimarães (University of Lisbon), Prof Marcella Milana (University of Verona), Prof Balasz Németh (University of Pécs), Dr Kira Nierobisch (University of Education in Ludwigsburg), Prof Hajo Petsch (University of Würzburg), Prof Sabine Schmidt-Lauff (Helmut-Schmidt-University in Hamburg), and Prof Bolanle Simeon-Fayomi (Obafemi Awolowo University in Ile-Ife).

Thank you very much to all the reviewers named at the end of this volume. Thank you to the colleagues at the Professorship of Adult and Continuing Education at Julius-Maximilian University in Würzburg. Special thanks to the coordinator of the COMPALL Winter Schools, Stefanie Kröner. Thank you very much to Jenny Fehrenbacher and Monika Staab for their support during the COMPALL project. Thank you to Clara Kuhlen, Lisa Breitschwerdt, Reinhard Lechner, Jutta Rüttger, and all student assistants at the professorship for their support.

\section{References}

Autorengruppe wb-personmonitor: Das Personal in der Weiterbildung. W. Bertelsmann: Bielefeld. 2017.

Bieber, Tonia / Martens, Kerstin:"The OECD PISA study as a soft power in education? Lessons from Switzerland and the US". European Journal of Education, 46(1) 2011, pp. 101-116.

Charters, Alexander / Hilton, Ronald (eds.): Landmarks in International Adult Education. Routledge: London, New York. 1989.

Egetenmeyer, Regina (ed.): Adult and Lifelong Learning in Europe and Beyond. Comparative Perspectives from the 2015 Würzburg Winter School. Peter Lang: Frankfurt a.M. et al. 2016. 
Egetenmeyer, Regina / Schmidt-Lauff, Sabine / Boffo, Vanna (eds.): Adult Learning and Education in International Contexts: Future Challenges for its Professionalisation. Comparative Perspectives from the 2016 Würzburg Winter School. Peter Lang: Frankfurt a.M. et al. 2017.

Egetenmeyer, Regina: "Comparative Studies in Adult Education and Lifelong Learning: The Joint-Module Methodology and its Context". In: Egetenmeyer, Regina / Guimarães, Paula / Németh, Balázs (eds.): Joint Modules and Internationalisation in Higher Education. Reflections on the Joint Module "Comparative Studies in Adult Education and Lifelong Learning". Peter Lang: Frankfurt a.M. et al. 2017, pp. 127-141.

Egtenmeyer, Regina: "What to Compare? Comparative Issues in Adult Education." In: Slowey, Maria (ed.) Comparative Adult Education. Authors and Texts. Firenze University Press: Florence. 2016, pp. 79-116.

Lattke, Susanne / Egetenmeyer, Regina: External Evaluation COMPALL. Midterm Survey 2017 of Former Participants of the International Winter School. Unpublished draft report. German Institute for Adult Education: Bonn. 2017.

European Union (EU): Council conclusions of 26 November 2012 on education and training in Europe 2020 - the contribution of education and training to economic recovery, growth and jobs (2012/C 393/02). Official Journal of the European Union: Brussels. 2012, retrieved 30.7.2017, from http://eur-lex. europa.eu/LexUriServ/LexUriServ.do?uri=OJ:C:2012:393:0005:0007:EN:PDF.

Klatt, Malgorzata: "Understanding the European Union and its Political Power". In: Milana, Milana / Holford, John (eds.): Adult Education Policy and the European Union. Theoretical and Methodological Perspectives. Sense: Rotterdam. 2014, pp. 53-71.

Kohli, Martin: "Die Institutionalisierung des Lebenslaufs. Historische Befunde und theoretische Argumente". Kölner Zeitschrift für Soziologie und Sozialpsychologie 37(1) 1985, pp. 1-29.

Marcussen, Martin: "OECD Governance through Soft Law“. In: Mörth, Ulrika (ed.): Soft Law in Governance and Regulation. An Interdisciplinary Analysis. Edward Elgar: Northampton. 2004, pp. 103-126.

Strzelewicz, Willy / Raapke, Hans-Dietrich / Schulenberg, Wolfgang: Bildung und gesellschaftliches Bewusstsein. Kohlhammer: Stuttgart. 1966.

Tough, Allen: The Adult's Learning Projects: A Fresh Approach to Theory and Practice in Adult Learning. Toronto: OISE. 1971.

Young, Michael F. D.: Implementing National Qualifications Frameworks: Problems and Possibilities. In: Maclean, Rupert / Wilson, David (eds.): International Handbook of Education for the Changing World of Work. Springer Netherlands, 2009, pp. 2917-2933. 
Regina Egetenmeyer and Monica Fedeli - 978-3-631-73704-0

Downloaded from PubFactory at 01/11/2019 10:08:46AM

via free access 


\section{Lifelong Learning Policies Targeting Employment Contexts}


Regina Egetenmeyer and Monica Fedeli - 978-3-631-73704-0

Downloaded from PubFactory at 01/11/2019 10:08:46AM

via free access 


\title{
Jan Schiller, Sabine Schmidt-Lauff \& Fabio Camilloni
}

\section{Comparing temporal agendas of policies and institutions in (work-related) adult education}

\begin{abstract}
Policies of the European Union contain a certain temporal agenda based on a conception of functionalistic, manageable, and abstract time. The text shows how this agenda has significant but different influences on national strategies (Italy and Germany) in the field of (work-related) adult education, such as the historicity or distribution of time and participation.
\end{abstract}

\section{Introduction}

At a first empirical glance, time is understood - similar to money - as a resource. Time seems to be one of the important factors of conceptualisation and even participation in lifelong learning in modern societies. As recent statistics show, the main reason for non-participation in adult education - formal or non-formal all over the OECD countries seems to be a lack of time (OECD, 2014, Tab. C6.5, and 2016). Different duties and learning activities in our accelerating world (Rosa, 2005) are in a state of constant competition over the scarce time resources of each individual lifetime. To solve this time conflict individually, innovations in competent time balancing are seen as a solution for combining adult learning with other time-related aspects of adult life, such as work, family, and recreation. This conception of time strongly resembles a functionalistic, management-type paradigm. That leads to the central question: How did this management-driven paradigm of time and learning become the leading temporal paradigm in (European) adult education?

In a first step, a short recapitulation of certain contemporary conceptions of time shall be laid out. Secondly, the role given to adult education in this setting is analysed. In the third step, the temporary paradigm and some phenomena are analysed in comparative terms and described via national laws, regulations, and social partners in Germany and Italy. Both countries have unique adult education systems that are influenced directly or indirectly by European policies. Whereas the German system strongly relies on institutions (time 'rulers' such as trade unions), the Italian system is guided mainly by laws (time regulations). In the last step, selected PIAAC data on (1) the distribution of time between formal and non-formal education and (2) the motivation for (non-)participation in adult education is presented in comparative terms to point out these differences. 


\section{Towards 'modern times' in contemporary capitalism}

Citing Norbert Elias' conception of time as a social dimension that is dependent on its own historicity, Leccardi (2013, p. 252) states that our understanding of time is the result of an evolutionary route, tending more and more towards an abstract conception of time (which means measured time) as the complexity of society grows. The question would arise how and in what direction contemporary capitalism has modified the temporal coordinates of early modernity. The sociologist David Harvey gives a thorough account of the impacts of postmodern production on society: New technologies in production and flexible accumulation, vertical disintegration intensifying the labour process and the need for reskilling to meet new labour needs, a shift in consumption from goods to services, and the dematerialisation of money (to name a few examples) lead to an overall instantaneity, a temporariness that is described as an intensified time-space compression (Harvey, 1990, pp. 284-286, 297). In a similar vein, Leccardi states that earlier understandings of space and time have been altered through the means of electronic communication technologies: As they accelerate the economy and society alike, the temporal profundity of one's life is replaced by a succession of instants. As a result, simultaneity functions as a new normative ideal. On top, globalisation creates a single (global) temporal system, whose core is instantaneousness (Leccardi, 2013, p. 253). The question is: What does that mean for everyday life and work in general, and adult education in particular?

As the world 'gets smaller', significant changes in the temporal structure of work and life in general can be seen. Alhadeff-Jones, Lesourd, Roquet, and Le Grand (2011, p. 397) state that in every moment one knows what is happening on the other side of the world and, depending on one's work, has to constantly adjust to it. This changes the individual's relationship to past, present, and future. AlhadeffJones et al. see a key challenge for adults in the development of the capacity to pilot the temporalities and rhythms of their own life, meaning to be able to connect their own past, present, and future to negotiate changes and transformations in life (ibid.). This explicitly does not only mean learning time management but learning how one relates to time. Following Nowotny, what we experience is an 'extended present', as constant change and time pressure decrease our temporal horizon. We have to focus on the 'now' in the 'real-time' moment (ibid.). Harvey calls it 'playing the volatility right' (Harvey, 1990, p. 286), Leccardi talks about 'projectuality' (2013): being highly adaptable, flexible, and fast moving instead of relying on (now) difficult long-term planning. 
Given the emphasis on the present to near future, adult education becomes the role, and lifelong learning becomes an instrument to cope with the constant need to adapt to transformation in modern Western society - in a purely functionalistic and affirmative way. As Schmidt-Lauff and Bergamini (2017, p. 99) critically state, lifelong learning is often the answer to the erosion of temporal structures: 'Learning over the lifespan emerges as an example of a successful (educational) biography'. Lifelong learning thus becomes a norm, matching the ideal of simultaneity or individual managerialism.

\section{Movements in-between adult education and the economy}

The above-mentioned functionalistic approach to lifelong learning can also be found in its supposed role for economic prosperity in European policies. Lima and Guimarães (2011, pp. 25-27) describe a policy shift from the welfare state to the neoliberal state starting in the 1970s; humanistic and social democratic policies were abandoned in favour of a new capitalistic configuration inspired by what they call managerialism. Economically, a transition from the post-war model of full employment supported by the welfare state towards a knowledge-based society produces constant transformations. Thus, constant fundamental change stresses the need for lifelong adaptation. Ideologically, a shift from state-centred welfare to market-centred individual responsibility took place that shows strong similarities to the postmodernist condition described by Harvey above. The relations between education, learning, and employment changed along with that shift: '[E]ducation is reconfigured as a form of knowledge that makes it possible to decide on the future of work, the organisation of knowledge institutions, and the way society will be in the future.' (Lima \& Guimarães, 2011, p. 27)

According to Lima and Guimarães (2011, p. 29), UNESCO was particularly important in developing adult education as a public policy segment. A main reason for the commitment to lifelong education and the combination of formal, non-formal, and informal types of education lays in the fact that since at least World War II, many countries' education systems failed to fulfil the expectation of upward social mobility through traditional formal education systems. As UNESCO-published research like R. H. Dave's Foundations of Lifelong Education (1976) shows, the promotion of lifelong education to overcome 'the dead end of equality of opportunity' (p. 150) and to cope with the 'changing requirements of the system' (p. 151) paralleled the neoliberal economic turn of Western societies.

In 2016, Lima, Guimarães, and Touma combined the description of shifting state priorities concerning adult education into a framework that depends mainly on three idealised models: the democratic-emancipatory model, the modernisation 
and state control model, and the human resources management model. The latter one strongly resembles aspects of the postmodernist condition and its effects mentioned above in the context of lifelong learning. It 'stresses the withdrawal of the state that is justified with the internationalisation of the economy, global competition, and diminishing public resources' (Lima, Guimarães, \& Touma, 2016, p. 39). In the human resources management model, learning, especially seen as lifelong adaptation to labour needs, is a responsibility of the individual. Accordingly, the model focuses on the acquisition of competencies in the context of employment, contradicting the modernisation and state control model's focus on formalised education aimed at qualification (ibid., p. 36).

At this point, we can summarise that the contemporary economic configuration and its concept of education require lifelong adaptation to transformations in all parts of life, especially focused on employment. Adaptation most often translates into gaining specific competences, which leads to a temporal pronunciation of the (extended and accelerated) present in favour of the past and distant future in the context of learning. As we want to show, this functionalistic conception of time can be traced in European and national educational policies, promoting a functionalistic concept of education named 'lifelong learning'.

Nowadays, the EU concept of lifelong learning incorporates aspects of various earlier models: Whereas OECD's 1970s concept of 'recurrent education' mainly focused on alternating phases of (mostly formal) education or training and work (Trappman \& Draheim, 2009, p. 534), and UNESCO's visionary and emancipatory 'lifelong education', as laid out in the 1973 Faure report, proposed 'learning to be' in a learning society (Faure et al., 1973), lifelong learning combines both the employment focus of OECD and the temporal simultaneity of UNESCO, in an ever accelerated condition. In addition, the described shift from public to personal responsibility described by Lima et al. requires 'lifetime flexibility' (Greenwood \& Stuart, 2006, p. 115). Lifelong learning thus refers to both Leccardi's simultaneity as well as Harvey's temporariness in a space-time-compressed environment, including a 'biographical dimension' (Trappman \& Draheim, 2009, p. 534) through individual temporal responsibility. In the Memorandum on Lifelong Learning, the Commission of the European Communities laid out its picture of a future Europe: Redrawing the changes to society described above, the document defines them as an 'overall transition to a knowledge society, whose economic basis is the creation and exchange of immaterial goods and services. In this kind of social world, up-to-date information, knowledge and skills are at a premium' (EC, 2000, p. 7). 


\section{Temporal strategies of lifelong learning}

The adult education systems of Germany and Italy are the product of their respective history. Both systems are directly influenced by European policies (Lima \& Guimarães, 2011; Lima et al., 2016). But as complex as the national systems are, the effects of EU influence are the same. Accordingly, the following sections will give a small insight into major strategies concerning temporalities (e.g. historicity, functionalisation and explicitly of learning time, future shaping of lifelong learning strategies) of each country to introduce the respective paradigms considering 'Europeanisation' factors.

\section{Historical developments (laws and social partners)}

The EU concept of lifelong learning has undoubtedly had a strong impact on the German adult education sectors. Two main reasons can be identified: First, the adult education sector in Germany is traditionally highly diverse, and thus hard to reform as a whole. Second, the strongly corporatist character of policy-making includes many stakeholders, which often follow their own agendas. A 'Europeanisation' of German lifelong learning policies in the way of a 'central penetration of national systems of governance' (Olsen, 2002, p. 923), meaning 'domestic impacts of European-level institutions' (ibid., p. 932) occur, if at all, fractional. The fact that the states have jurisdiction over education in Germany has produced 16 different, sometimes similar laws covering adult education. Many of them originally date back to the 1970s by referring to the ILO C140 Convention, concerning free learning time via Paid Educational Leave (ILO, 1974). The federal adult and continuing education laws provide for a legal foundation of the highly diverse and heterogeneous system of adult education and training in Germany (institutions, programmes, financing, target groups, learning time, etc.).

Historically, the development of adult education laws in Italy started (like in Germany) in the 1970s. The national law 300/1970 art. 10 and many national collective agreements of 1973 define and declare the right to study for workers. The law promotes the education of workers, who are entitled to a certain number of paid hours off work (maximum 150 hours per year, but up to 250 for employees who need to obtain a basic level of compulsory education) to attend any kind of institution or certified organisation offering courses related or not related to their professional activities. Learning time - as hours per year - are clearly defined and therefore triable. Art. 10 also defines the number of individuals who can be absent from the company to attend courses at the same time. Further agreements of paid (or unpaid) education for workers are described in national workers' agreements, 
trade union agreements, and the individual job contract. Workers who are enrolled in any formal educational courses (such as a bachelor's or a master's degree) have the right to a paid day off to take exams (see below).

Different and not easily compulsory, was the development of the 'Quaternary Segment: Adult Education' in Germany: The political struggle over the future shape of vocational education and continuous training was and is strongly influenced by important stakeholders, especially the 'social partners' (trade unions, their associations, and the employers' associations). The managerialist approach of the EU lifelong learning concept does not go unchallenged by those institutions. Temporal and formal/non-formal aspects of learning and working play a major role in this struggle, too. Both policy-makers and the social partners rely strongly on scientific analyses to strengthen their point.

In the Italian context, concepts such as adult education and lifelong learning are still not common and sometimes confused. Adult education is defined as 'an educational offer, both formal and non-formal, aimed at and designed for adults (Italians and migrants)' (La Marca, n. d.) and is considered a responsibility of the state (policy). It is possible to divide offerings into two macro-categories: first, adult instruction, or Istruzione degli Adulti, which concerns literacy skills or the achievement of a formal diploma (e.g. high school diploma); it is entrusted to the Ministry of Education. It is accompanied by professional training, or Formazione Professionale, which is administrated by the regions and provinces (in partnership with other entities) (Gallina, 2016). The first category, as will become clear in the next paragraph, targets people who are unemployed and people with a gap in their education. The second macro-category concerns continuous training, or Formazione Continua. It refers to activities connected to professional development and employee requalification (ISFOL, 2016). In 1997, the Italian ministerial decree 455/97 represented the first step towards the concretisation of adult education (first category). Nowadays, after years of evolution and reforms, the main protagonists (for formal education) of adult education are the 'Provincial Centres for Adult Education' (Centri provinciali per l'istruzione degli adulti CPIA). Most of the adults who attend formal courses there have special needs regarding time (e.g. due to their job). The full-week courses offered by the centres are organised in the evenings to be more accessible to potential learners to earn the desired formal diploma. CPIA offerings are not limited to primary, secondary, or upper secondary school, they also include functional literacy courses (literature, foreign languages, IT, etc.) and literacy and social integration courses for foreigners (Gallina, 2016). 


\section{Learning-time regulations}

For Germany, an overall regulation about learning-time (as the 150 hours of learning per year in Italy) does not exist. But the concept of paid educational leave includes the 'Länder Regulations', which deal with educational leave (Bildungsurlaub, Bildungs- und Freistellungsgesetze). Fourteen out of sixteen German states have these legislative options. Every employee has the option to request approximately five days of paid leave per year to participate in specifically accredited courses on differing topics (mostly vocational but also language courses, study trips, political topics, etc.). The instrument's primary objective is to grant employees time off to participate in learning outside the work environment in something outside of their employability focus. Some states have further instruments (e.g. educational vouchers or Bildungsscheck) to encourage adults to take learning time by means of financial stimuli.

In some aspects comparable to the above-mentioned German situation, the Italian Law 53/2000 Art. 5 regulates learning times. Most of the initiatives are directed in a human resources management model view, which focuses on the empowerment of individuals and their competences to support the economic view of new public management: the market orientation. Law 53/2000 Art. 5 re-regulates the time aspect regarding workers, who can ask time off work for educational purposes that must be related to the work context. Individuals who have accumulated five years of seniority in the same company or organisation can request up to 11 (unpaid) months, consecutive or not, with respect to the whole work-related lifetime. The training leave concerns only the training activities and education activities not organised by the employee. Article 6 of the same law, incorporating the 5th as its evolution, declares the right to education and training, including the right to leave for continuous training, employed or not, to develop professional knowledge and competence. The training, in this case, can be proposed by the employee and be granted together by the employer and social partners. The regions and autonomous provinces (Trento and Bolzano) are responsible for funding the project - with funding received from individuals or organisations (companies, NGOs, associations, training bodies, etc.) - and for communicating the data and prospective developments.

To communicate and reflect on the data for a supporting concept in Germany, the closing report of the 'Independent Expert Commission on Funding Lifelong Learning' (Unabhängige Expertenkommission zur Finanzierung Lebenslangen Lernens (UEK), 2004) was published as a strategic paper. It defines objectives to 'propose funding suggestions that are suitable to promote innovation, economic growth and social cohesion' (UEK, 2004, p. 12). Knowledge and learning are seen 
as key factors for economic development; Bildung as an investment in human capital (p. 18), which, through innovation, promotes economic growth. The impact of knowledge expansion is estimated to be higher the faster new knowledge is created (p. 17). The key resources for this investment in the individual and collective future of a knowledge-based economy and society are time and money (p. 33). The report thoroughly presents the many different possibilities in which way the temporal and financial costs of this 'investment' can be shared between state institutions, companies, social partners, and individuals. The expert commission recommends a set of instruments that divide the overall costs between these stakeholders. For job-related learning, the resources are provided by employers (learning during work-time, financial costs) and individuals (learning during nonpaid work time and leisure time) (p. 187). This division follows the basic rationale that companies, on the one hand, should be responsible for vocational education and training investments, but that individuals, on the other hand, should contribute adequately to the costs (p. 182). From the commission's viewpoint, workrelated learning agreements should become a standard paragraph in employment contracts (p. 235). Learning-time accounts are seen as a suitable instrument and should be further developed (p. 236).

\section{Partnerships - to the future of lifelong learning - struggling between general adult education and vocational education and training}

The national government started to stimulate partnerships and networking in Italy in 2001 with Directive no. 22/01, which declared that there should be an integrated system of institutions and organisations responding to the educational and instructional needs of the population, referring also to their culture and the level of education. Formal adult education, as explained before, is not only about literacy and instruction. Professional training, which is more connected to the Ministry of Labour, is the other side of the coin, fostering the possibilities for people who do not have any certification or diploma giving them access to a profession. It is strongly connected to adult instruction; it relates to basic competences and knowledge in formal certificate/diploma courses, designed to transmit professional skills for middle- and low-qualified jobs. Professional training is organised in collaboration with the region or the province and other entities, such as regional professional training bodies, universities, public technical and professional institutions, and companies.

After six years, not least because of the influence of the EU agenda aims and the goals of the European Social Fund (ESF), an Italian financial law (269/06, art. 632) was passed describing the duties of the whole national system with respect to 
regions, local entities, and the aims imposed by the EU. Adult education direction has been shaped with the European aim to increase educational attainment. Since the beginning, the EU has played a central role because of the strong financial subsidies for courses and activities, mostly for professional training and continuous training. As a consequence, the EU and the ESF started to play a central role influencing the providers.

The situation is similar for the non-formal education side, where associations, non-profit organisations, training bodies, and third-age universities are engaged in the same search for funds. Each entity coordinates the design of its programmes and courses in cooperation with the region and the province to be able to obtain funds that allow the entity to offer courses for individuals. One of the most important laws defining and giving a protocol to lifelong learning and hence adult education is law 92/2012. Before that law was passed, a direct definition of lifelong learning, as connected to formal, non-formal, and informal education did not exist; neither was there a focus on learning as the most important principle for personal, civic, social, and professional growth. It is clear how the definition and inspiration refers to the Memorandum on Lifelong Learning (EC, 2000). The law was introduced by the Ministry of Economic Development in collaboration with the Ministry of Education, University, and Research, and the Ministry of Labour and Social Policy. The law took effect in 2013 with the national administrative order number 13, which underlines the right to lifelong learning of every individual.

To underline the German context and its conceptualisation of lifelong learning as vocational education, two examples of governance partnerships should be presented here: The trade union pamphlet 'Education is not a Commodity' (Bildung ist keine Ware, Bayer et al., 2006) and the trade union campaign 'My Life - My Time' (Mein Leben - Meine Zeit, IG Metall, 2015).

The trade union pamphlet 'Education is not a commodity' (Bayer et al., 2006) focuses on the effects of employment on the employed but covers the same considerations. The authors acknowledge there is a broad consensus in society to implement lifelong learning in everyday work relations (p. 84). The process of doing so, on the other hand, seems to be far from completed (p. 84). From their viewpoint, the vocational education system is facing a crisis (p. 2) rooted in the accelerated pace of economic development. To solve this crisis, they recommend a list of objectives that the trade unions should fight for. Lifelong learning should provide individual ways of access, shared responsibility (of employers and employees), and reliable regulations. The authors acknowledge that investing in society's human capital (such as lifelong learning), as demanded by politicians, today also includes self-responsibility, meaning the privatisation of costs (p. 84). They argue that the 
promised benefits for the individual from personal investment into continuing education and training are highly questionable. They state that new allocation patterns emerge in practice, which in general foster individual responsibility for indirect costs, mainly through temporal resources (p. 85). Contributing time can evoke 'temporal conflicts' between different qualities of time, meaning different responsibilities that require one's time. The risk of time conflicts is not equal for all employees, relating to individual conditions of income and life in general (p. 85), and different time responsibilities in detail: family, side jobs, overtime hours, to name a few. The general shift towards individual responsibility for adaptation gets formalised in time-sharing agreements between the companies and the employees. The new 'allocation patterns' require time contribution by the employees not only in self-initiated learning but also in learning that is directly required by the job (p. 88). From the trade unions' point of view, this trend is the result of a shift of power between employers and employees - and it is the responsibility of the state to reverse it, mainly by taking up extensive financial responsibility for continuing education, which to this date is not the case (p. 89).

Launched in 2015, the trade union campaign 'My life - my time' (IG Metall, 2015) showcases a number of steps the trade unions believe have been achieved since the 2006 pamphlet. One of the key points are regulations concerning the shared investment of temporal resources into work-related learning: the so-called 'educational part time'. Since 2015, agreements have been made with different economic sectors (employers' associations) to regulate the contribution of time (and financial resources) to qualification arrangements for employees. The unions' rather strong position is evident from the fact that these arrangements concern self-initiated learning, that is, learning not necessarily directly required by the current employment. Learning directly required for the job should be the sole responsibility of employers. 'Educational part time' could mean vocational qualification and upper secondary or tertiary education, for example. Employees gain the right to reduce working time in favour of learning time for up to seven years while remaining eligible to return to full-time employment afterwards. Learning time can be full time or part time (next to the job), whilst retaining at least 50 per cent of wage payments. Employees can increase their earnings during educational part time by regular payments into educational accounts. Moreover, they can invest financial (special payments, savings) and temporal resources (e.g. overtime hours) to increase wage payments during the learning phase up to a targeted 70 per cent of the former full-time payment. 


\section{Empirical view on learning times: Comparative PIAAC data analysis}

In the following section, the effects of both systems are 'temporally' traced again, empirically within the PIAAC data (Programme for the International Assessment of Adult Competencies) collected by the OECD.

\section{Temporal resources for learning}

The PIAAC data on Germany (OECD, 2016) provide empirical background that clearly shows the challenges or even disparities between political policies and the reality of adult education and training (AET). Focussing here only on time-related data, a trend of mostly non-formal education at the workplace versus formal education outside of employment arrangements can be reconfirmed by looking at the contribution of temporal resources:

Table 1: Distribution of time between formal and non-formal education with employed interviewees.

\begin{tabular}{|l|l|l|l|l|}
\hline & \multicolumn{2}{|c|}{ Germany } & \multicolumn{2}{c|}{ Italy } \\
\hline & $\begin{array}{l}\text { Formal } \\
\text { Education }\end{array}$ & $\begin{array}{l}\text { Non-formal } \\
\text { Education }\end{array}$ & $\begin{array}{l}\text { Formal } \\
\text { Education }\end{array}$ & $\begin{array}{l}\text { Non-formal } \\
\text { Education }\end{array}$ \\
\hline Working hours only & $17.2 \%$ & $53.3 \%$ & $4 \%$ & $49 \%$ \\
\hline Mostly working hours & $10.9 \%$ & $13.6 \%$ & $5 \%$ & $14 \%$ \\
\hline Mostly in non-working hours & $13.1 \%$ & $5.8 \%$ & $19 \%$ & $8 \%$ \\
\hline Non-working hours only & $58.8 \%$ & $27.4 \%$ & $72 \%$ & $29 \%$ \\
\hline
\end{tabular}

Source: OECD (2016), own arrangement (Variables B_Q10b; B_Q15b), ISFOL. (2013). PIAAC-OCSE - Rapporto nazionale sulle Competenze degli Adulti. ISFOL.

For Germany, we can see that the highest rate (58.8\%) of learning occurs in the formal AET segment but outside of the workplace (formal learning during 'non working hours only'). At the same time, 53.3 per cent of learning as non-formal education takes place during 'working hours only'. All in all, 50.3 per cent of employed interviewees participated in formal or non-formal AET for job-related reasons in the 12 months before the interview (without table). What is more, 43.7 per cent participated in non-formal education for job-related reasons (only 7.5\% for non-job related reasons).

For Italy, the PIAAC data show fairly similar proportions. Whereas formal AET is mainly done in an 'out of the office' setting ( $72 \%$ of formal learning during 
'non-working hours only'), non-formal AET takes place mainly at work (49\% during 'working hours only' versus $29 \%$ during 'non-working hours only').

Table 1 clearly shows that the temporal resources for formal education are mainly invested outside of working hours - both in Italy and Germany. Temporally, this provokes the 'competent time balancing management paradigm' in modern lives, as pointed out in the introduction. On the one hand, it seems problematic that workplace-related demands (skills and knowledge) - which are available via formal learning activities - compete strongly with private time, individual personal or social/family time, recreation, and so forth. On the other hand, the individual responsibility for formal qualification seems to be very strong. By adding monetary aspects to the PIAAC data for Italy, we can find that most non-formal education in Italy is fully or partially paid for by the employer $(50 \%$; cf. ISFOL, 2013, pp. 146-161). And most of the formal education is paid for by employees (31\%); the majority (61\%) of learners had to pay for it completely in order to be able to get the job they were looking for (ISFOL, 2013). Although the emphasis in both countries is on non-formal education during working hours, and formal education outside of working time, the values show slightly different pronunciations: While in Germany much more people take part in formal education during work time, those approx. 13 per cent are placed in strictly non-work time hours in Italy. But more research and reflection on the data is needed to connect it to the described struggle of the social partners in Germany described above. Do 'time-sharing' investments between employers and employees already work in Germany?

\section{Temporal reasons for non-participation}

For both countries, the reasons given for non-participation in any learning activity confirm the prominent meaning of temporal resources (Table 2). In Italy, 38 per cent of the non-participants reported the educational activity was in conflict with their working time; in Germany 31.3 per cent reported the same conflict. Another 18 per cent in Italy and nearly 14 per cent in Germany did not have time because of family reasons. Concerning gender (no table), family reasons were the main obstacle for women (the main reasons for men concerned work) in both countries. Whether this would be different with so-called 'time-management' or 'work-life balance' schemes in place could not be answered with this data (for a critical analysis, cf. Schmidt-Lauff \& Bergamini, 2017). Nonetheless, we propose a critical view here, which reflects structural problems and cultural phenomena as well, in the specific 'functional conception of time' in modernity, as pointed out above. 
Table 2: Distribution of the reasons for non-participation in educational/training activities.

\begin{tabular}{|l|l|l|}
\hline Motivation for non-participation & Germany & Italy \\
\hline Not required & $1.9 \%$ & $3 \%$ \\
\hline Too expensive & $10.1 \%$ & $16 \%$ \\
\hline Not supported by employer & $9.8 \%$ & $3 \%$ \\
\hline Too busy with work & $31.3 \%$ & $38 \%$ \\
\hline Too far, or not at a good time & $15.1 \%$ & $6 \%$ \\
\hline Did not have time because of family reasons & $13.6 \%$ & $18 \%$ \\
\hline Unexpected commitment & $2.6 \%$ & $3 \%$ \\
\hline Other & $13 \%$ & $13 \%$ \\
\hline
\end{tabular}

Source: OECD (2016) (Variable B_Q26b); ISFOL. (2013). PIAAC-OCSE - Rapporto nazionale sulle Competenze degli Adulti, pp. 159-160, authors' arrangement.

The obstacle of accessibility (geographic and temporal) is nearly three times higher in Germany than in Italy (15\% versus 6\%). This is surprising, because the infrastructure as well as the number of providers or the wide range of courses seems to be extraordinary in Germany (e.g. more than 905 Volkshochschulen; DIE, 2014). Likewise, the difference between employer support ('not supported by employer') is three times higher in Italy than in Germany ( $9.8 \%$ vs. $3 \%$ ), which is surprising for us. For Germany, there seems to be a distinct disparity between the political discourse on work-related learning or lifelong learning and reality. This disparity could be interpreted as a sign of political development that has not yet come to an end.

\section{Conclusion}

When comparing the situation in Italy and Germany, it becomes clear that the EU policies' influence on national (work-related) adult learning and education is much more diverse than policies assume. Historically grown systems follow national structure (e.g. the federal system in Germany) as well as international influences (the ILO Paid Educational Leave as an orientation for Italian laws and German regulations). Nonetheless, transformations in both countries are orientated towards the European perspective of highly dynamic economies and accelerated times in general. Time becomes more and more a (countable) resource, politically and economically hard-fought and challenged between human wants, personal interests, family needs, and employers' interests (production, profit). Different stakeholders, according to their respective historicity, struggle to shape the 
future of the lifelong learning system. Whereas in politically corporatist Germany, the social partners have a strong influence next to the rather diverse state laws, the policy influence in Italy proves to be much higher.

However, the centre of both the German and the Italian stakeholders' attention is on dividing the shares of financial and temporal resources in 'educational investments' (Schmidt-Lauff, 2003). The human resources management model's individual responsibility for personal qualification clearly shows in the time investment of individuals. 'Playing the volatility right' seems to be not only a question of personal disposition but also of labour politics in an accelerative modern society.

\section{References}

Alhadeff-Jones, Michel / Lesourd, Francis / Roquet, Pascal / Le Grand, Jean-Louis: "Questioning the Temporalities of Transformative Learning in a Time of Crisis". In: Alhadeff-Jones, Michel / Kokkos, Alexis (eds.): Transformative Learning in Time of Crisis. Individual and Collective Challenges. Proceedings of the 9th International Transformative Learning Conference. Teachers College, Columbia University \& The Hellenic Open University: New York \& Athens, Greece 2011, pp. 394-407.

Bayer, Mechthild / Faulstich, Peter / Jaich, Roman / Heimann, Klaus / Brügmann, Wolf-Gunter (eds.): Bildung ist keine Ware. Wie wir morgen arbeiten, leben und lernen wollen. Eine Streitschrift zur beruflichen Bildung. IG Metall/Verdi: Berlin / Frankfurt am M. 2006.

Dave, Ravindra H. (ed.): Foundations of Lifelong Education. Pergamon Press: Oxford et al. 1976.

DIE Trendanalyse: Trends der Weiterbildung. W: Bertelsmann: Bielefeld 2014.

European Commission: A Memorandum on Lifelong Learning. Commission staff working paper SEC (2000) 1832. 2000, retrieved from http://pjp-eu.coe.int/ documents/1017981/1668227/COM_Sec_2000_1832.pdf/f79d0e69-b8d348a7-9d16-1a065bfe48e5.

European Commission: Education and Training Monitor 2016 - Italy. European Union: Brussels 2016.

Faure et al.: Learning to Be. The World of Education Today and Tomorrow. UNESCO: Paris 1973.

Gallina, Vittoria: Educazione in età adulta: una opportunità e una scommessa per il sistema educativo italiano. EPALE 2016, retrieved from https://ec.europa.eu/ epale/sites/epale/files/educazione_in_eta_adulta_articolo_vgallina-epale.pdf. 
Greenwood, Ian / Stuart, Mark: "Employability and the Flexible Economy. Some Considerations of the Politics and Contradictions of the European Employment Strategy. In: Alonso, E. L. / Martinez Lucio, M. (eds.): Employment Relations in a Changing Society. Assessing the Post-Fordist Paradigm. Palgrave Macmillan: Basingstoke 2006, pp. 104-119.

Harvey, David: The Condition of Postmodernity. An Enquiry into the Origins of Cultural Change. Blackwell: Malden et al. 1990.

IG Metall: Mein Leben - meine Zeit. Arbeit neu denken. 2015, retrieved from https://www.igmetall.de/arbeitszeit.htm.

ILO International Labour Organisation: Convention concerning Paid Educational Leave. 1974, retrieved from http://www.ilo.org/dyn/normlex/en/f?p=NORML EXPUB:12100:0::NO::P12100_ILO_CODE:C140.

ISFOL: PIAAC-OCSE - Rapporto nazionale sulle Competenze degli Adulti. ISFOL 2013.

ISFOL: XIV Rapporto di monitoraggio delle azioni formative realizzate nell'ambito del diritto-dovere. ISFOL 2016.

La Marca, Teresa: Adult Education in Italy. (n.d.) retrieved from http://www. infonet-ae.eu/country-overviews/italy.

Leccardi, Carmen: "Temporal Perspectives in De-standardised Youth Life Courses". In: Schroer, Wolfgang / Stauber, Barbara / Walther, Andreas / Böhnisch, Lothar / Lenz, Karl (eds.): Handbuch Übergänge. Beltz: Weinheim \& Basel 2013, pp. 251-269.

Lima, Licinio C. / Guimarães, Paula: European Strategies in Lifelong Learning. A Critical Introduction. Budrich: Opladen et al. 2011.

Lima, Licinio C. / Guimarães, Paula / Touma, Nathalie: "Adult Learning and Education Policies in Germany, Portugal and Sweden: An Analysis of National Reports to CONFINTEA VI". In: Egetenmeyer, Regina (ed.): Adult Education and Lifelong Learning in Europe and Beyond. Comparative Perspectives from the 2015 Würzburg Winter School. Peter Lang: Frankfurt 2016.

OECD: Education at a Glance. OECD Publishing: Paris 2014, retrieved from https://www.oecd.org/edu/Education-at-a-Glance-2014.pdf.

OECD: “PIAAC Data on Germany”. Public Use File, 2016, retrieved from http:// vs-web-fs-1.oecd.org/piaac/puf-data/SPSS/.

Olsen, Johan P.: “The many faces of Europeanization”. Journal of Common Market Studies 40 (5), 2002, pp. 921-950.

Rosa, Hartmut: Beschleunigung. Suhrkamp: Frankfurt a.M. 2005.

Schmidt-Lauff, Sabine: "Betriebliche Lernzeitstrategien - Empirische Studien zur Umsetzung von Weiterbildung in Betrieben”. Europäische Zeitschrift für 
Berufsbildung 29, 2003, pp. 71-79 (translated into English, French, Spanish and Portuguese), retrieved from http://www2.cedefop.europa.eu/etv/Upload/ Information_resources/Bookshop/349/29_en_SchmidtLauff.pdf.

Schmidt-Lauff, Sabine / Bergamini, Roberta: "The Modern Phenomenon of Adult Learning and Professional Time-Sensitivity. A Temporal, Comparative Approach Contrasting Italy and Germany". In: Egetenmeyer, Regina / SchmidtLauff, Sabine / Boffo, Vanna (eds.): Adult Learning and Education in International Contexts. Future Challenges for its Professionalization. Peter Lang: Frankfurt a.M. et al. 2017, pp. 98-107.

Trappmann, Vera / Draheim, Susanne: "Lebenslanges Lernen: Gewerkschaften und Kompetenzentwicklung im aktivierenden Sozialstaat". WSI Mitteilungen 10, 2009, pp. 533-539, retrieved from https://www.boeckler.de/wsimit _2009_10_trappmann.pdf.

Unabhängige Expertenkommission zur Finanzierung Lebenslangen Lernens: $A b$ schlussbericht. Der Weg in die Zukunft. UEK: Bonn 2004, retrieved from http:// www.koop-son.de/fileadmin/user/Dokumente/2008/schlussbericht_kommiss ion_lll.pdf. 


\title{
Arunima Chauhan, Hyejin Bak, Shreelakshmi Subbaswamy \& Vijay Kumar Dixit \\ Lifelong learning and skill development policies and programmes: A comparison between India and South Korea
}

\begin{abstract}
In the era of knowledge-based economies, vocational education and skill development activities have gained a central place on global and national agendas. The paper tries to throw light on the development of vocational education and skill development policies and programmes in India and South Korea.

The comparison is made in terms of the concept of vocational education, the actors involved, the target group, and the evolution of policies and programmes. The paper also highlights the interdependencies of the vocational education and the employment context in both countries.
\end{abstract}

\section{Introduction}

The world is changing at a greater pace in social, cultural, economic, technologi$\mathrm{cal}$, and environmental domains; as a consequence, there is rapid change in human affairs worldwide, which necessitated a revision of adult education and its reconfiguration as lifelong learning. According to Shah (2015), India's interest in lifelong learning has been greatly influenced by the global discourse on lifelong learning, especially the advocacy by transnational actors like UNESCO and the European Union. The idea of lifelong education is not new - the concept has been expressed by philosophers and educators throughout the centuries - but the importance given to the lifelong education has varied over time and place. The global discourse of lifelong learning initiated by UNESCO, especially after the publication of Learning: The Treasures Within (1996) and the Memorandum of Lifelong Learning of the Commission of the European communities (2000), played a crucial role in shaping India's lifelong learning policy. While UNESCO worked with government officials and tried to influence the national adult education policy, the European Commission made systematic attempts to promote lifelong learning through universities. The European specialists persuaded the University Grants Commission to formulate lifelong learning policy and programmes at Indian universities (Shah, 2015). 


\section{Lifelong education and learning}

denotes an overall scheme aimed both at restructuring the existing education system and at developing the entire educational potential outside the education system in such a scheme where men and women are the agents of their own education, through continual interaction between their thoughts and actions; education and learning, far from being limited to a period of attendance at school, should extend throughout life, include all skills and branches of knowledge, use all possible means, and give opportunity to all people for full development of the personality; the educational and learning processes in which children, young people and adults of all ages are involved in the course of their lives, in whatever form, should be considered as a whole. (UNESCO, 2005, pp. 70-71)

It is unfortunate to say that the richness of the concept of lifelong learning has not been translated into policies and programmes in the countries; in the Indian context, for example, we can see that lifelong learning is often used as an umbrella term to cover basic literacy, post literacy, continuing education, and extension programmes of different organisations, refresher/continuing courses of professional bodies, private institutions and business houses; but not conceived as an overarching framework of learning. The Global Monitoring Report 2015/2016 (World Bank Group \& International Monetary Fund, 2016) makes a remark on the present status of lifelong learning in the world by reporting that the aims of lifelong learning have not been fully achieved. In the globalised world, countries are interested in growing their economies at a greater pace. Knowledge is the major driving force of the economy, and thus more attention is paid to knowledge and skill acquisition. This rising demand for knowledgeable and skilled personnel has alarmed the countries to make skill development and human resource development activities the top priority on national policy agendas.

The concept of skill development, vocational education, and its activities has far-reaching meanings and orientations. Skills development enhances both people's capacities to work and their opportunities at work, offering more scope for creativity and satisfaction at work. The future prosperity of any country depends ultimately on the number of persons in employment and on how productive they are at work. On the one hand, skills are one of the major factors for economic production and growth; on the other hand, skills have a great influence on personal development, learning, the standard of living, and social participation. A skilled and productive workforce more efficiently produces higher standards of goods and services, which in turn forms the basis for faster economic growth and rising living standards. Countries across the world have embraced the concept of skill development differently. For some countries like China and India, professional development, up-skilling, and soft skills are the main focus in skill development 
activities, whereas for some countries, including South Korea, basic vocational skills are the focus (Mohanty, 2007).

In the present scenario, skill development is at the forefront of national agendas and policies. In India, the Ministry of Skill Development and Entrepreneurship was established on 9 November 2014 to coordinate all skill-related initiatives (Ministry of Skill Development and Entrepreneurship, 2017). Skill development activities vary by countries due to historical, socio-economic, and political developments. In complex societies, the employment context is influenced by the economy, the public, and civil society. The emergence of skill development and vocational education policies and programmes over time serves as a window for understanding the interdependency of skill development policies and vocational education policies with the employment context. This paper aims to answer the following questions:

1. How has skills training in lifelong learning emerged and developed in both countries?

2. Who are the providers of skills training in both countries?

3. What are the differences and similarities in skills training and vocational education in both countries?

The paper not only identifies the need for vocational skills development in India and South Korea but also explores the evolution of skill development and vocational policies. Towards the end, the policies are compared in terms of aims, actors, targets, and their interdependency with the employment context.

\section{The Indian context}

India is a South Asian country with a population of 1.3 billion. It has a diverse socio-cultural context and widely varying demographic and socio-economic conditions. India is a developing country and one of the youngest nations in the world, with more than 54 per cent of the total population aged below 25 years. India's workforce is the second largest in the world (MHRD, 2016). 62 per cent of India's population lies in the working age group (15-59 years), and 90 per cent of its workforce works in the unorganised sector (Ministry of Skill Development and Entrepreneurship, 2015). The term 'unorganised sector' refers to enterprises owned by individuals or self-employment workers and engaged in the production or sale of goods or services of any kind. If such an enterprise employs workers, their number is fewer than ten (Ministry of Law and Justice, 2008). The working age group (15-59 years) can produce the desired result if they are adequately skilled. 


\section{What is a skill?}

Skill means the ability to apply knowledge and use know-how to complete tasks and solve problems. Skills are described as cognitive (involving the use of logical, intuitive and creative thinking) or practical (involving manual dexterity and the use of methods, materials, tools and instruments). (Government of India, 2013, p. 1)

\section{Need for skill development in India}

India has had a need for skill development since the times it was ruled by the British. The need intensified with independence, as there was a huge demand for skilled workers in the labour market due to globalisation, technological change, and innovation - key factors that influenced the kind of work done and the way of doing it. In recent times, the economic growth of any country is driven by the knowledge and skills of its population. 'India is in transition to a knowledge based economy and its competitive edge will be determined by the abilities of its people to create, share and use knowledge more effectively. (Goel, 2011, p. 1). For a smooth transition, it is necessary that India make its workers more adaptable and skilled.

Employment opportunities are affected by supply- and demand-side issues. On the supply side, professionals entering the job market are lacking in required skills, and on the demand side, there are not enough job opportunities. India's restrictive labour laws are partly responsible for discouraging growth in industry and employment. For instance, labour laws restrict units that employ more than 100 workers from firing employees (Skilling India, 2010). A study report released by the Ministry of Skill Development estimated an incremental human resource demand of 109.73 million by 2022 (MSDE, 2016). On the other hand, only 2 per cent of the total workforce in India has presently undergone skills training. This shows that there is a large section of the working population who are to be skilled for jobs (FICCI, 2015).

Skill development of the unskilled is one issue; the employability and productivity of those entering the labour market is another. As per the 2015 India Skills Report, conducted by Wheebox, India's leading online talent assessment company, only 37.22 per cent of the people surveyed were found employable. The National Sample Survey Office (2010) showed that only 10.1 per cent of the labour force had received vocational training, with only 25.6 per cent of them receiving formal vocational training. India is ranked last among 60 countries on labour productivity (GOI, 2010).

In India, there is a large skill gap as well as a skill shortage. In simple terms, a skill gap can be defined as the difference between the skills needed for a job 
versus the skills possessed by a prospective worker. Two types of skill gap can be observed: first, a low-educated, unskilled labour force entering the labour market and second, an educated labour force unable to find jobs matching their qualification due to their lack of technical and soft skills. A survey of 303 employers across the country by the Federation of Indian Chambers of Commerce and Industry (FICCI) in 2010 found that a majority of graduates lacked adequate 'soft skills' to be employed in the industry. The Federation of Indian Chambers of Commerce and Industry survey found that only 26 per cent of employers are satisfied with their employees' ability to communicate in English, 'the most widely used professionally communicated language'.

Skilling and upskilling is imperative for the country's economic development and its ability to compete with other economies in the knowledge-driven society. Various policies and programmes have been launched by the Government of India to become the most productive workforce in the world.

\section{Development of skill development policies and programmes in India}

Skill development and vocational education have existed in India since ancient times, when people did all kinds of work on their own. Back then, skills were usually transferred from father to son. Over time, the idea of skill development has changed in the country. During pre-independence time, the British needed technicians in various areas, hence technical and vocational colleges were started in the country. During this phase, the education system in India was bookish and focused more on literacy; much less energy was devoted to vocational skill development. In response, many commissions and committees were formed to design strategic plans for setting up a vocational education system in India.

\section{Pre-independence}

Officially, vocational education was advocated and planned by the Abbot-Wood Report in 1936-37. This report recommended a hierarchy of vocational and training institutions to be run parallel at the institutions imparting general education (Government of India, 1967). In the pre-independence period, the Central Advisory Board of Education (1943), the Sargent Committee (1944), and the Sarkar Committee (1945) were put in action to plan various aspects of technical education and vocational education in the country. India won independence in 1947, and the country had to address lots of problems like poverty, unemployment, literacy, and so on. In order to address these problems and improve its economy, providing vocational training to its citizens was imperative. 


\section{Post-independence}

After independence, the Secondary Education Commission (1952-53) called for introducing craft and vocational education in secondary schools, and the Kothari Commission (1964-66) suggested providing students with vocational courses at the school level to develop their interest, skills, and capacities in various vocational fields. It also suggested that students should be given the opportunity to get admission to industrial training institutes and polytechnic institutions. The National Education Policy (1986) envisaged vocational training to counter the mismatch in the demand and supply of skilled manpower. The National Institute of Open Schooling (NIOS) was given the task of providing vocational education and training programmes to general and prioritised groups (Goel, 2011, p. 9). There were also organisations like the National Renewal Fund (1991-2000), which aimed at providing a safety net to employees affected by modernisation and technological advancements. It provided training as well as funds for self-employment (GK Today).Vocational education in India is associated with the formal education system, from the secondary education level to the higher education level. Skill development programmes are programmes separate from the formal education system.

After independence, skill development programmes focused on the rural population, the illiterate, neo-literates, women, and the disadvantaged. Some examples of the programmes are: Support to Training and Employment Programme for women (1986), established to give women the competencies and skills to become self-employed/entrepreneurs; Gramin Vikas Trust (1992), established for vocational skill training of rural youth and adults; Jan Shikshan Sansthans, created to meet the educational and vocational training needs of illiterates and neo-literates in the age group of 15-35 (Jaganatthan, 2013).

\section{Towards the establishment of the Ministry of Skill Development and Entrepreneurship}

In its 11th Five-Year Development Plan (2007-2012), India became serious about skill development; as a result, a series of steps were taken for skill education and training. There was a vast expansion of industrial training centres, polytechnics, vocational schools, and skill development centres to provide youth and adults with access to vocational training. The 11th Plan gave a very high priority to higher education. Initiatives such as establishing 30 new central universities, 5 new Indian Institutes of Science Education and Research (IISER), 8 Indian Institutes of Technology (IIT), 7 Indian Institutes of Management (IIM), 20 Indian Institutes of Information Technology (IIIT, and the like were taken to meet the challenge of skill development (Skill Development and Training, 2010). During the 11th 
Five-Year Plan, various councils and bodies were created. First, the National Skill Development Council (NSDC) was set up to coordinate various schemes provided by various ministries; second, the National Skills Development Board (NSDB) was set up to coordinate 17 relevant ministries; third, the National Skill Development Corporation (NSDC) was created to operate in a public-private partnership mode (PPP) involving industry associations and industry representatives to upgrade training institutions and deliver vocational training; fourth, Sector Skills Councils were set up for about two dozen sub-sectors involving various interested industrial associations to identify skills gaps and enhance skills training in each sub-sector. Also during this period, India's first National Skill Development Policy was brought out in 2009, and subsequently, the National Skill Development Mission was launched in 2010 .

The National Policy on Skill Development covered institution-based skill development training, formal and informal apprenticeships, and other types of training by enterprises, training for self-employment, adult learning, training of retired or retiring employees and lifelong learning, non- formal training by civil society organisations, e-learning, web-based learning, and distance learning.

In 2010, the first national manufacturing policy was issued with an emphasis on skills development as a strategy to strengthen India's manufacturing sector. It also emphasised skill development for minimally educated workers in the unorganised sector. And as a result of this policy, the Modular Employable Skills (MES) scheme was started, and trainees were awarded certificates for the skills they learned. In 2013, India came up with the first National Skills Qualification Framework (NSQF). It is a competency-based framework that organises all qualifications according to a series of levels of knowledge, skills, and aptitude. These levels, graded from one to ten, are defined in terms of learning outcomes that the learner must possess, regardless of whether they were obtained through formal, non-formal, or informal learning. Under the NSQF, learners can acquire certification for competencies needed at any level through formal, non-formal, or informal learning (National Skill Qualification Framework, 2013). NSQF was followed by the National Vocational Education Qualification Framework (NVEQF) in 2013, which provides guidelines for a nationally recognised qualification system to standardise training contents, set national standards, and recognise the skills learned at schools, vocational training institutes, and higher education institutions. The NVEQF has led to the close collaboration and partnership of the government with industry to develop courses, curricula, assessment, certification, and placement (MHRD, 2013). 
In spite of all these developments, the 12th Five-Year Plan observes that the skill development programmes in the past had no sufficient connection to market demand, revealing poor collaboration with the labour market (GOI, 2013). Against this background, the government created a Ministry of Skill Development and Entrepreneurship.

The main role of the ministry includes coordination, development of frameworks, mapping of skills and certification, institute-industry linkages, and other tasks. The ministry works primarily through the National Skill Development Corporation (NSDC), the National Skill Development Agency (NSDA), and the Directorate of Training (DT). Projections show that 500 million people need to be skilled by 2020 . Out of the 500-million target, the National Skill Development Corporation (NSDC) was directed to skill 150 million, whereas the Directorate General of Employment and Training (DGET), under the Ministry of Labour and Employment, was mandated to skill 100 million. Figure 1 shows the increase in the number of trained people by NSDC. Currently, there over 20 different government bodies implementing over 70 skill development schemes at the state and central levels (MSDE, 2016).

Figure 1: Persons trained by the National Skill Development Corporation (NSDC).

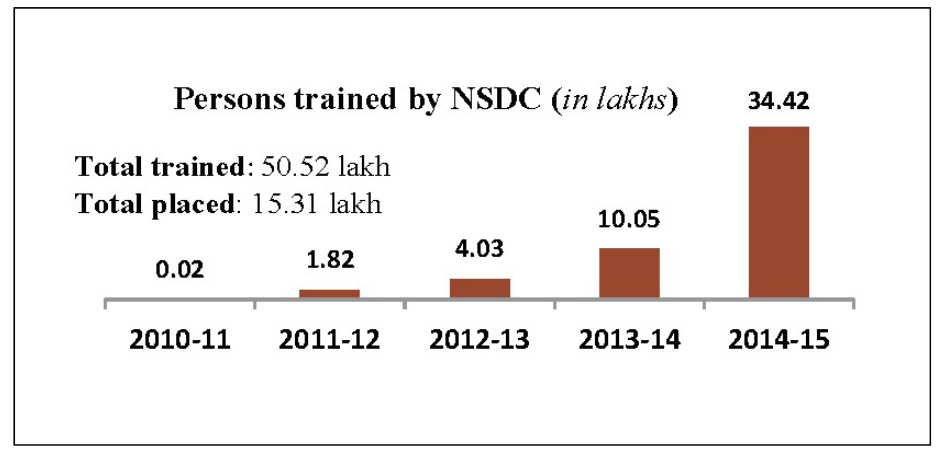

Source: Ministry of Skill Development and Entrepreneurship (2016)

The most recent development in the skill development area is the launch of a National Policy for Skill Development and Entrepreneurship in 2015, aiming to accelerate the skilling activities in a high-quality and sustainable manner. Designed to align all skilling activities with the demand side, the policy focuses on increasing capacity and synergies among the existing schemes, promoting global partnership and inclusivity, streamlining entrepreneurship in the education system, improving the ease of doing business, and providing access to funding. 
India has the potential to produce a skilled workforce not only within the country but also to fulfil the expected shortage in the ageing developed world. The 2015 National Policy for Skill Development and Entrepreneurship emerged as an umbrella term covering all the skilling activities in the country. It also identified the overall institutional framework to reach the expected outcome. The responsibility is to be shared among government, the entire spectrum of the corporate sector, community-based organisations, outstanding highly qualified individuals, and others (Ministry of Skill Development and Entrepreneurship, 2015).

To sum up, the government of India has taken a series of steps, by establishing ministries and departments, to make its working-age population skilled enough to enter the labour market. The post-independence skill development policy and programme targeted mainly the rural population, the illiterate, and women, but in recent times, the target group has been expanded to include rural, urban, skilled, and unskilled populations, neo-literates, women, youth, and adults. In the past, skill development activities were mainly undertaken by the government. The present policy adopts a public-private partnership (PPP) model for skill development activities, in which the government collaborates with private agencies working in the field of skill development to provide large-scale skill development training throughout the country. This has helped to mobilise resources and create links to the labour market. Whereas skill development programmes in the past had poor linkages with the labour market and industries, at present there is an increasing linkage and partnership with the labour market at both the local and global levels through the PPP model. NSDC has 203 training partners under its PPP model, including for-profit as well as non-profit entities. In the last four years, these training partners have trained over two million people in more than 25 sectors, at 2500+ fixed and mobile centres, in over 350 districts across the country (Skill Development in India, 2015). There is sea change in governmental strategies from providing opportunities for employment to emphasising entrepreneurship. The concepts

of soft skill development, upskilling, sustainability of skills, and entrepreneurship have gained a central place on the national agenda and policy documents. Above all, the skill development policies and activities in India are mainly demand-based and hugely dependent on the labour market.

\section{The South Korean context}

South Korea is officially called the Republic of Korea. It is a sovereign state in East Asia. The population is $51,732,586$ with a population of $43,735,000$ above 15 years (Statistics Korea, 2017). South Korea is a technologically advanced and developed country driven by a highly educated and skilled workforce. 
The main concept of vocational education and skill development in South Korea is 'National Human Resources Development'. Human resources include human abilities and qualities including knowledge, skills, and attitudes that are necessary for individual, societal, and national development (NHRD, 2011).

\section{The concept of Human Resources Development (HRD)}

The concept of human resources development refers to the overall activities of central and local governments, education institutions, research institutes, and corporations that cultivate, allocate, and leverage human resources and develop relevant social norms and networks - in short, activities related to developing human capital and social capital (NHRD, 2011).

Human capital: the ability to increase productivity and wealth through economic activities using the knowledge, skills, and capability embedded in individuals.

Social capital: intangible assets that create social cohesion and trust, including a sense of morality, cooperation, and social norms.

\section{The concept of National Human Resources Development (NHRD)}

NHRD means comprehensive efforts at the national and societal level to develop and efficiently manage human capital and social capital in order to promote knowledge creation, utilisation, and distribution for individual development and national competitiveness (NHRD, 2011).

\section{The need for National Human Resources Development}

In South Korea, human resources were relatively immobile. They gained importance with respect to strategy, policy, and programmes due to globalisation, which increased the free flow of capital, technology, and information across borders. In other words, the development and dissemination of technology and the globalisation of information increased the importance of not technology or information in themselves but of quality human resources that can absorb, develop, and utilise them (NHRD, 2011).

The advent of the lifelong learning society required sustainable and systematic training of human resources. As knowledge is spreading rapidly and changing fast, time- or space-restricted education can no longer meet the learning and knowledge needs of managing an advanced economy. Thus, there was a dire need for the creation of sustainable human resource development in the country and a robust education system (NHRD, 2011). 
National competitiveness and socioeconomic restructuring are ultimately sustained by the restructuring of human resources. Thus, government ministries and offices made collective efforts to support continuous learning and education training for individuals (NHRD, 2011).

The increased importance placed on human resources development in the world has made it easier for government ministries and offices to introduce human resources development and management as major policy area in their overall policy (NHRD, 2011).

\section{The development of vocational education policies and strategies in South Korea}

As mentioned earlier, vocational education and skill development come under the umbrella of National Human Resource Development, which is managed by the Korea Research Institute for Vocational Education and Training (KRIVET) (Lee, 2016). Steady investment in human resource development has triggered the driving force of development, including economic growth in South Korea. In the early 1960s, human resource development was promoted in the Five-Year Economic Development Plan to recognise the importance of resources and to pay attention to its development and application (Lee, 2004). In this section, we will briefly consider how vocational education policy changed after the 1960s, and then moves to explore how vocational education is classified as a part of lifelong learning (LLL), and how it is emphasised. Lastly, the direction of vocational education and training is contemplated through the research and project directions of KRIVET, which is a national research institute about Korean vocational education.

\section{The shift of vocational education priorities in the past}

In 1945-1960, promoting technical and vocational education was a policy in order to cultivate skills and attitudes for practical life, with an emphasis on the one-man, one-skill principle (Song, Min, \& Seong, 2009).

In 1960-1970, the system of vocational education was promoted. From 1962, vocational education saw innovative change due to the Five-Year Economic Development Plan. During this time, vocational high schools began to be fostered under the education policy aiming to nurture industrial manpower while the industrialisation policy was executed (Song, Min, \& Seong, 2009).

From the mid-1970s to the 1980s, vocational education policy focussed on meeting the demand of industrial manpower for economic development. The 1970s focus on training technicians for efficiency shifted to a higher educationcentred focus on training advanced engineers to prepare for industrial 
advancement in the 1980s. Then, the framework of the education structure was established as 'demand-centred education' for political and social reasons (Song, Min, \& Seong, 2009).

\section{Enacting the Lifelong Education Act}

Meanwhile, in the early 1990s, as public demand for education reform increased, the Education Reform Committee was established as a presidential advisory body to systematically promote education reform in 1993. And the Education Reform Commission legislated the Lifelong Education Act, which replaced the existing social education law in 1999 (Kim et al., 2010a).

Likewise, it means that the previous concept of 'supply-centred social education' converted into the concept of 'demand-centred lifelong education' in order to build the lifelong learning system, which allows everyone to have and keep their education anywhere and at any time (Kim et al., 2010a).

The second Lifelong Education Act was enacted by the Korean government in 2007. The act reinforced lifelong education support policies for the educationally underprivileged and supported education for diploma achievement, basic adult literacy, vocational capacity-building, liberal arts, culture and arts, and education on civic participation beyond traditional formal education (MEST \& NILE, 2009). In terms of vocational education, the act promoted structured learning activities in the workplace and activated vocational lifelong learning (Lee, 2010). It also granted employees paid or non-paid study leaves and payment for study expenses (e.g. book purchases) and research (Lee, 2010).

\section{Vocational competency education in the Korean Lifelong Education Programme Classification Scheme (KLPCS)}

KLPCS means 'Korean Lifelong Education Programme Classification Scheme', and it includes six large categories and three sub-categories for each large category. The six large domains of the programme are classified similarly to the legal classification of Lifelong Education: 'Basic Literacy Education', 'Schooling Complementary Education, 'Vocational Competency Education,' 'Culture \& Arts Education,' $\mathrm{Hu}$ manities \& General Education', and 'Citizen Participatory Education' (Kim et al., 2010b, pp. 224-225; NILE, 2013, cited in Han \& Park, 2015, p. 999). 
Table 1: Vocational competency education in KLPCS.

\begin{tabular}{|l|l|l|}
\hline \multirow{4}{*}{$\begin{array}{c}\text { Vocational } \\
\text { Competency } \\
\text { Education }\end{array}$} & $\begin{array}{l}\text { Professional } \\
\text { Preparation } \\
\text { Programme }\end{array}$ & $\begin{array}{l}\text { Hoping to get a job in a specific career and new } \\
\text { knowledge necessary for successful entrepreneurship, } \\
\text { information, technology, and programmes to help } \\
\text { acquire the functionality to prepare the relevant } \\
\text { conditions systematically }\end{array}$ \\
\cline { 2 - 3 } & $\begin{array}{l}\text { Expertise necessary to perform particular career duties, } \\
\text { Pkills, functions, programmes that help you to reach } \\
\text { a certain level of certification for certain qualified } \\
\text { institutions }\end{array}$ \\
\cline { 2 - 3 } & $\begin{array}{l}\text { Continuing } \\
\text { Professional } \\
\text { Development } \\
\text { Programme }\end{array}$ & $\begin{array}{l}\text { This is for incumbent workers to acquire the knowledge } \\
\text { and information needed for the development of work } \\
\text { performance and programmes to help you learn and } \\
\text { acquire the relevant technology and features }\end{array}$ \\
\hline
\end{tabular}

Source: Han \& Park (2015), p. 999; Kim et al., 2010b,) pp. 224-225

In the Vocational Competency Education domain, there are three functional elements: 'Professional Preparation Programme, 'Qualification and Licenses Programme', and 'Continuing Professional Development Programme' (Kim et al., 2010b, pp. 224-225). Table 1 contains a description of each function element.

As Table 1 shows, it seems that vocational education is no longer part of supporting industrial society, nor does it focus on basic skills. Instead, it is realistic and future-oriented for 'pre-', 'in-'and 'continuous-'education for vocational necessities and purposes.

The actions taken by the government have increased the participation of paid workers in education and training. Figure 2 shows that the education and training participation of paid workers has increased by 21 per cent over the past five years, from 32.2 per cent in 2010 to 53.2 per cent in 2015.

At this juncture, it is worth mentioning the research and project directions of KRIVET, because these directions substantially reflect the prevailing practical vocational education and training trend in South Korea. Some of the directions of KRIVET strengthen research on future human resources development policy, intensify research on lifelong career education policy, strengthen research on employment and skills development policy, consolidate support for the establishment of a competency-based society, and reinforce global cooperation in HRD (KRIVET, 2016). First, Korean vocational education and training might be regarded as investment-oriented and future-oriented. That is because at present, the education system is designed to prepare workers for the concept of 'human 
resources', whereas in the past, the focus was on providing the necessary workforce to meet the demand of industry and society.

Figure 2: Rate of education and training participation of paid workers in South Korea.

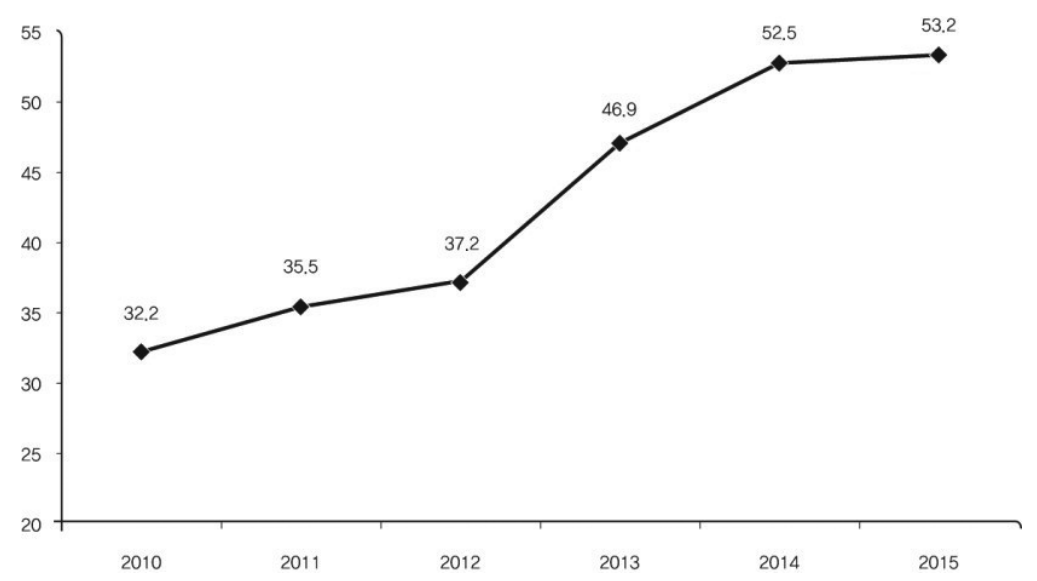

Source: KRIVET (2016), p. 14

Besides, vocational education aims at increasing 'potential' as much as improving ability, enabling workers to acquire and develop any skill, in line with the concept of 'competency', instead of simply acquiring and advancing a certain skill.

Moreover, current vocational education and training is promoted and supported at all levels - individual, corporate (where the individual belongs), and national. And it seems to aim at reflecting both local and global situations, whereas domestic industries and society were the primary reference for education in the past.

Therefore, it seems that Korean vocational education policy seeks to emphasise 'long-term' sustainability, unlike previous policies, which were relatively 'short-term'.

\section{Conclusion}

The conceptualisation of vocational education and skill development differs in India and South Korea. In the case of South Korea, vocational education and skill development focuses on the overall development of an individual, whereas in India, it is focused more on developing the skills that make an individual employable. South Korea has a Lifelong Learning Act dedicated to imparting skills, whereas 
such an act is missing in the Indian context. However, in both countries, improving people's skills for economic development has become the major concern of the state. A comparison makes the differences visible. In India, skill development focuses on basic vocational skills in a vast range of fields. Previously, skill development programmes targeted rural populations, women, and youth; at present, it targets the jobless, college and school dropouts, and educated persons from rural and urban areas. In South Korea, under the umbrella of Vocational Competency Education, all professional preparation programmes, continuing professional development, and in-service professional development are carried out. In both countries, the policies and programmes have led to increased participation in skill development activities. As in South Korea, vocational education is part of the lifelong learning continuum, and all the involved ministries work together. India also involves numerous ministries as well as various public and private players in skill development activities, but coordination between ministries is not as strong as in South Korea. The analysis of the governance of vocational and skill development activities shows that India, in spite of its centralised governmental regulations, has decentralised skill development activities and involved private partners in the implementation. In South Korea, strong governmental regulation is seen in vocational education policies and practices. In South Korea, skills training is mostly covered by the Lifelong Learning Act, whereas India has numerous policies in place which contribute to the formulation of skill development policies. Structurally, we can say that India has a more decentralised system than South Korea in terms of imparting skills.

Finally, both countries focus on developing people's skills to compete in the knowledge economy. In both countries, vocational education and skill development policies are interconnected with the employment context, although the level of interdependency in each country varies. The concepts, policies, strategies, and practices with regard to skill development and vocational education have varied over time, depending on the political system, history, demographics, and the country's socioeconomic development. The skill development field is young in India and has only become prominent in the recent past. In South Korea, by contrast, skill development and vocational education have been emphasised since the 1940s, and the field has taken various shapes and now is a major part of the country's lifelong learning system. There are also research institutes developing the knowledge base in the field for further improvement.

Comparing policies, strategies, and programmes helps each country develop innovative and robust vocational education systems. Each country's skill development system has its own origin and evolution, and it is influenced by the 
history, political system, socio-economic conditions, and demographics. Hence the development of skill development and vocational education systems can be compared but not replicated. Furthermore, the discussion has opened up ways to seek opportunities for cross-country collaborations to learn from each other and understand different ways of developing policies and strategies. However, in India, the focus is on basic vocational skill development, and it is a challenge to move towards lifelong learning, unlike in South Korea, where vocational education is part of human resource development and the lifelong learning continuum.

\section{References}

Chowdhury, Kavita: "Young India Lacks Soft Skills: Survey". Indiatoday, 10.04.2011, retrieved 18.06.2017 from http://indiatoday.intoday.in/story/a-survey-findsa-majority-of-graduates-lack-adequate-soft-skills-to-be-employed/1/134857. html.

Commission of the European Communities: A Memorandum of Lifelong Learning. European Commission: Brussels 2000.

CRISIL Centre for Economic Research: Skilling India. The Billion People Challenge. A report by CRISIL Centre for Economic Research. CRISIL: Mumbai, 2010, retrieved 27.06.2017 from https://www.crisil.com/pdf/corporate/skillingindia_nov10.pdf.

Federation of Indian Chambers of Commerce and Industry: Skilling India. A Look Back at the Progress, Challenges and the Way Forward. KPMG in India: New Delhi 2014.

GK Today, no date, retrieved 15.06.2017 from https://www.gktoday.in/.

Goel, Vijay P.: Technical and Vocational Education and Training (TVET) System in India for Sustainable Development. UNEVOC: Bonn 2011.

Government of India, Ministry of Human Resource Development: National Policy on Educatin 1986. New Delhi 1998.

Government of India, Ministry of Human Resource Development: Education Commissions and Committees in Retrospect. Report of the Education Commision, Comments \& Reactions. A Study. New Delhi 1967, retrieved 15.06.2017 from, http://www.teindia.nic.in/mhrd/50yrsedu/g/w/16/0w160301.htm.

Government of India: Report on Employment and Unemployment Survey. GIO: Chandigarh 2010.

Government of India: Twelfth Five-Year Plan 2012-2017. SAGE: New Delhi 2013 Han, Sang-Hoon (한상훈) / Park, Myeung-Sin (박명신): "An analysis of the AHP of the Lifelong Education Program based on the six classification scheme". 
Journal of the Korea Academia-Industrial Cooperation Society 16(2), 2015, pp. 995-1005.

India Skills Report 2015, retrieved 22.06.2017 from https://wheebox.com/logo/ India\%20Skills\%20Report2015.pdf.

Jaganatthan, Shanti: “Skill development: Promises, approaches in developed countries and emerging economies". ADB Briefs (19) 2013, pp. 1-8.

Kim, Jong Seo (김종서) / Kim, Shinil (김신 일) / Han, Soong Hee (한숭희) / Kang, Dae Joong (강대중): Introduction to Lifelong Education. Revised edition. Paju: Kyoyookbook 2010a.

Kim, Jin-Hwa (김진화). / Ko, Young-Hwa (고영화). / Kwon, Jae-Hyun (권재 현)./ Jeong, Min-Ju (정민주).: "Development of Korean classification scheme system for lifelong education program". Journal of Lifelong Education 16(3) 2010b, pp. 211-236.

Konrad Adenauer Stiftung: Skill Development in India. 2015, retrieved 19.06.2017 from http://www.kas.de/wf/doc/kas_42848-1522-2-30.pdf?151016072126.

Korea Research Institute for Vocational Education and Training: Research \& Project Directions in 2016. KRIVET: Seoul 2016, retrieved 24.06.2017 from http:// www.krivet.re.kr/eng/eu/ea/euGEADs.jsp.

Lee, Jung Eun (이정은): Implementation of Lifelong Learning Policies in South Korea: A World Society Perspective. Adult Education Research Conference. Kansas State University Libraries New Prairie Press: Sacramento 2010, retrieved from http://newprairiepress.org/aerc/2010/papers/45.

Lee, Ki Sung (이기성): "Implication for policy direction for the Human Resources Development (HRD) through current situation of vocational education and training for adults". Interdisciplinary Journal of Adult \& Continuing Education 7(2), 2004, pp. 43-70.

Lee, Yong-Soon (이용순): President's Message. KRIVET: Seoul 2016, retrieved 24.04.2017 from http://www.krivet.re.kr/eng/eu/ea/euGAADs.jsp.

Ministry of Education, Science and Technology \& National Institute for Lifelong Education: National Report on the Development and State of the Art of Adult Learning and Education. National Institute for Lifelong Education: Seoul 2009.

Ministry of Human Resource Development: Annual Report 2011-2012. MHRD: New Delhi 2013.

Ministry of Finance: Notification. to be published in the Gazette of India. MF: New Delhi 2013, retrieved 16.05.2017 from http://mhrd.gov.in/sites/upload_files/ $\mathrm{mhrd} /$ files/upload_document/NSQF- NOTIFICATION.pdf.

Ministry of Human Resource Development: Annual Report 2014-2015. MHRD: New Delhi 2016. 
Ministry of Law and Justice: The Unorganised Workers Social Security Act. MLJ: New Delhi 2008, retrieved 20.06.2017 from http://labour.tripura.gov.in/sites/ default/files/The_Unorganised_Workers_Social_Security_Act_2008.pdf.p. 2.

"Ministry of Skill Development and Entrepreneurship", Wikipedia, no date, retrieved 25.06.2017 from https://en.wikipedia.org/wiki/Ministry_of_Skill_Deve lopment_and_Entrepreneurship.

Ministry of Skill Development and Entrepreneurship: National Policy for Skill Development and Entrepreneurship. MSDE: New Delhi 2015, pp. 1-2

Ministry of Skill Development and Entrepreneurship: Human Resources and Skill Requirements in the Education and Skill Development Sector. MSDE: New Delhi 2016.

Ministry of Skill Development and Entrepreneurship: National Skills Qualification Framework. MSDE: New Delhi, no date, retrieved 22.05.2017 from http://www. skilldevelopment.gov.in/nsqf.html.

Mohanty, S.: Lifelong and Adult Education. APH Publishing Corporation: New Delhi 2007.

National Sample Survey Organisation: Employment and Unemployment Situation in India (66th Rounds). Ministry of Statistics and Plan Implementation, Government of India: New Delhi 2010.

National Human Resources Development 2011, retrieved 22.04.2017 from https:// www.nhrd.net/index.do? menuCd=DOM_000000107001000000.

Planning Commission Government of India: Eleventh Five Year Plan 2007-2012. Skill Development and Training. Oxford University Press: New Delhi 2008, retrieved 18.06.2017 from http://planningcommission.gov.in/plans/planrel/ fiveyr/11th/11_v1/11th_vol1.pdf.

Shah, S.Y.: Lifelong Learning in India: A Policy Perspective, Aarhus University: Aarhus n.d., retrieved 17.06.2017 from http://asemlllhub.org/policy-briefs/ lifelong-learning-in-india-a-policy-perspective/.

Song, Chang Yong (송창용) / Min, Joo Hong (민주홍)/ Seong, Yangkyoung (성 양경): “The Present Condition and Policy Trends of Vocational Education" (직 업교육의 현황과 정책동향, self-translated). The HRD Review, 12-55, 2009, retrieved 29.06.2017 from https://www.nhrd.net/board/view.do?dataSid=177 30\&boardId=BBS_0000002\&menuCd=DOM_000000102001000000.

Statistics Korea: 2017 May Employment Trend. Statistics Korea: Seoul 2017, retrieved 30.06.2017 from http:kostat.go.kr/portal/korea/kor_nw/2/3/2/index. board.

United Nations Educational Scientific and Cultural Organisation: Toward Knowledge Societies. UNESCO Publishing: Paris 2005, retrieved 18.05.2017 from http://unesdoc.unesco.org/images/0014/001418/141843e.pdf. 
United Nations Educational Scientific and Cultural Organisation: Education for All 2000-2015: Achievements and Challenges. UNESCO Publishing: Paris 2015. World Bank Group / International Monetary Fund: Global Monitoring Report 2015/2016. Development Goals in an Era of Demographic Change. International Bank for Reconstruction and Development / The World Bank: Washington, DC 2016, retrieved from http://pubdocs.worldbank.org/en/503001444058224597/ Global-Monitoring-Report-2015.pdf. 
Regina Egetenmeyer and Monica Fedeli - 978-3-631-73704-0

Downloaded from PubFactory at 01/11/2019 10:08:46AM

via free access 


\title{
Shalini Singh, Leonardo Silveira \& Janiery da Silva Castro
}

\section{Comparing the Continuing Vocational Education and Training Policies of Italy, Brazil, and India: What could be compared and what could not be compared, and why? ${ }^{1}$}

\begin{abstract}
This paper explores how the continuing vocational education and training policies in Italy, Brazil, and India are embedded in the economic context along the lines of productivity, labour market, and employability. It also reflects on countries as units of comparison in research.

Italy, Brazil, and India are sovereign countries and members of UNESCO. While Italy is a member country of the European Union, Brazil and India are BRICS countries, categorised as newly industrialized countries and known for their high growth rates. However, merely being a predefined geographical unit (countries) or political unit (sovereign states, UNESCO members) might be insufficient for scientific comparisons in the current transnational context.

In this paper, we compare the continuing vocational education and training policies in Italy, Brazil, and India and reflect on the selection of units of comparison for comparative studies in scientific research.
\end{abstract}

\section{Defining continuing vocational education and training}

The most widely used definition of continuing vocational education and training (hereafter CVET) in research and policy is the one by Cedefop (2014), which defines CVET as

education or training after initial education or entry into working life, aimed at helping individuals to improve or update their knowledge and/or skills; acquire new skills for a career move or retraining; continue their personal or professional development (Cedefop \& Tissot, 2014, p. 51).

1 The authors thank Professor Søren Ehlers (University of Aarhus), Professor Regina Egetenmeyer (Julius-Maximilian University of Würzburg), Professor Natália Alves (University of Lisbon), and Professor Paula Guimaráes (University of Lisbon) for their intellectual input while conceiving this article. 
Cedefop (2015) specifies that CVET can take place in formal, non-formal, and informal settings (Cedefop, 2015, p. 22). Cedefop (2015) refers to adult learning outcomes connected to professional development (vocational education) as 'continuing' only after an individual enters the labour market (Cedefop 2015, p. 23).

Cedefop defines CVET as a 'way to improve participation of adults in lifelong learning, reinforce their employability and increase employment in Europe' (Cedefop, 2015, p. 18). By contrast, for the OECD, entering the labour market is not the criterion to decide whether a VET programme is initial or vocational (OECD, 2015, p. 5). If the individual has received VET at a level in the European Qualification Framework, VET at the next level will be called continuing (OECD, 2015, p. 49). Therefore, for the OECD, the complexity of the function and the required competencies in VET are the criteria to decide whether it is initial or continuing VET (OECD, 2015, p. 49).

CVET is neither defined nor used by UNESCO. UNESCO uses the term 'technical vocational education and training' (TVET), ignoring the differentiation between initial and continuing VET. It defines TVET as

those aspects of the educational process involving, in addition to general education, the study of technologies and related sciences and the acquisition of practical skills, attitudes, understanding and knowledge relating to occupation in various sectors of economic life (UNESCO, 2017, online resource). ${ }^{2}$

Unlike Cedefop or OECD, it focuses more on soft skills and employability (McQuaid \& Lindsay, 2005; King 2009).

The operational definition of CVET for this paper is based on the definition adopted by Cedefop due to the clear distinction between initial and continuing VET. We therefore define CVET in this article as the

learning process of an individual in formal, non-formal and in-formal settings, within and outside the work environment, after entering and before retiring or finally leaving the labour market to improve professional knowledge, skills and competencies (International Winter School, 2017, personal communication). ${ }^{3}$

2 Unesco: TVETpedia, retrieved 15.05.2017, from http://www.unevoc.unesco.org/ go.php?q=TVETipedia+Glossary+A-Z\&term=Technical+and+vocational+educatio $\mathrm{n}+$ and +training.

3 This definition was agreed upon at the International Winter School, Comparative Studies in Adult Education and Lifelong Learning on 6-17 February 2017 in Würzburg, Germany, during the group work on lifelong learning and national/regional CVET policies with researchers from Portugal (Natália Alves), Italy (Beatrice Galligani), Brazil (Leonardo Silveira and Janiery da Silva Castro), and India (Donika Arora and Shalini 


\section{Research questions}

We focus on two research questions in this paper. The first research question discusses the way CVET policies are formulated in Italy, Brazil, and India, including primary influences on policies, actors, policy objectives, and target groups. The first research question is therefore:

\section{How is CVET policy (not) formulated in Brazil, Italy, and India?}

The second question builds on the first question, enquiring about the reasons why CVET policies were formulated in Italy and Brazil but not in India. The question is:

\section{Why are CVET policies (not) formulated in Brazil, Italy, and India?}

The question focuses on the context of comparison and investigates the linkages between the provisions, providers, target groups, and the societal sectors influencing CVET in the three countries.

\section{Analytical framework}

1. The 'relationship model for comparative research in adult education' for choosing the focus of research, designing the contexts, and formulating categories of comparison (Fig. 1): Egetenmeyer (2017) argues that the focus of research comparing adult education in different countries should be replaced by a comparison of contexts owing to the diverse range of providers, levels and modes of learning' in adult education, which could not be restricted to the boundaries of states and are rather transnational in nature (pp. 80-81). Egetenmeyer argues for designing contexts of comparison according to what is relevant for answering a particular research question rather than using predefined contexts (like states) as categories for comparison (p. 81). She argues to go beyond the predefined, traditional, hierarchical, or vertical structural arrangements and theoretical paradigms; politically driven empirical data sets (with categorisation) provided by transnational actors; and even the discipline of education to adopt an inter-disciplinary approach (p. 94).

Singh). The authors acknowledge the intellectual input from these researchers that informs this article. 
2. Figure 1: Relationship model for comparative research in adult education.

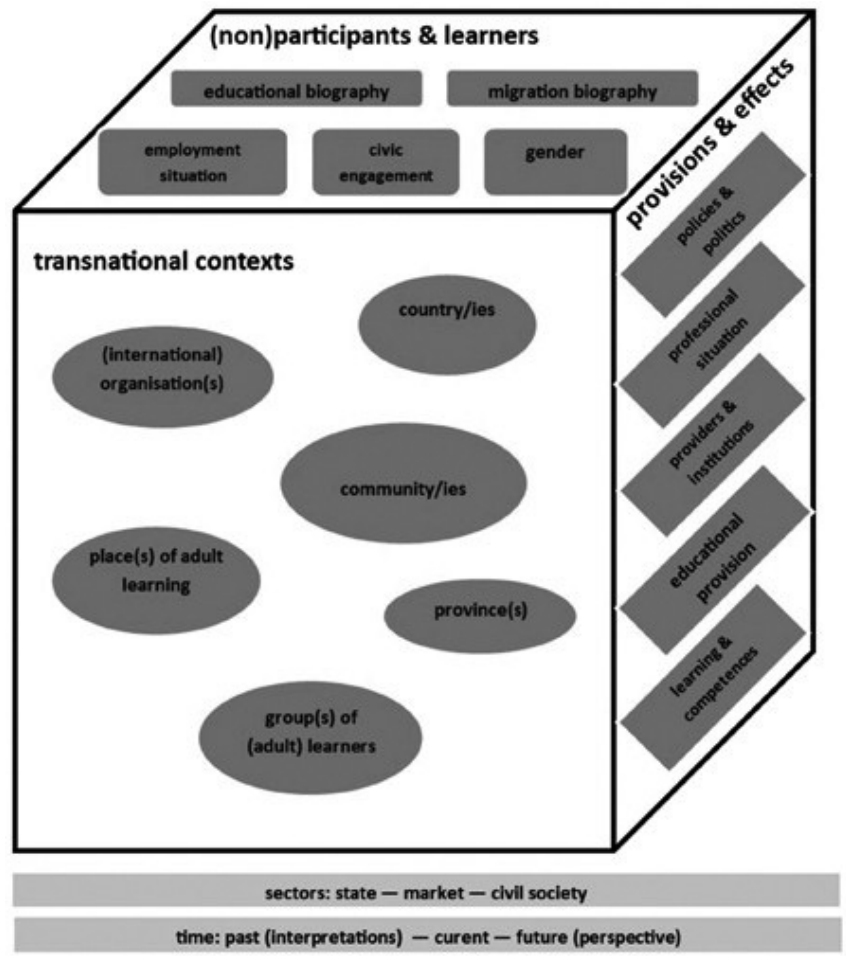

Source: Egetenmeyer's 'Relationship model for comparative research in adult education' (Egetenmeyer, 2017, p. 85)

In her model, Egetenmeyer proposes three dimensions of comparison that comprise the context of comparison:

a. provision \& effects

b. (non)participants \& learners

c. transnational contexts

Egetenmeyer argues that comparative research in adult education should be focused on 'provision \& effects' or the practices and the underlying phenomena in adult education. She suggests studying the linkages of these provisions and effects (policies, professional situation, providers and institutions, educational provision and/or learning and competencies) across the 'transnational contexts' in relation 
to '(non) participants and learners', embedded in time and the 'relevant societal sector (state, market, civil society)' (pp. 84-85).

We use the insights from Egetenmeyer's model and focus on the comparison of CVET 'policies' as 'provision \& effects' in the contexts of Italy, Brazil, and India, analysing the (non)existence of transnational contexts (transnational/national policy influences and providers) on the policies in question, the 'employment situation', 'civic engagement', and 'educational biographies' of '(non) participants and learners', embedded in the relevant societal sectors.

2. Analytical policy models for adult education to describe contexts in a structured manner: Lima and Guimarães (2011) propose to analyse policies along the following dimensions:

a) 'Political-administrative orientations': Policy formulation apparatus or legislative apparatus including 'laws, rules and norms'.

b) 'Political priorities': Objectives, target groups, and resource allocation.

c) 'Organisational and administrative dimensions': Policy implementation apparatus or bureaucratic apparatus.

d) 'Conceptual elements': Policy orientations.

(Lima \& Guimarães, 2011, pp. 39-66)

We use the four dimensions used by Lima and Guimarães (2011) as categories of comparison to compare CVET policies.

3. The 'box model' to understand whether the chosen units of comparison could be used for scientific comparison (Fig. 2): Ehlers (2006) argues that there are only four ways in education to understand totality: the ways of thinking (or approaches) in 'practice,' 'profession', 'science', and 'policy'. Ehlers emphasises that thinking in one way or box is not completely compatible with the thinking in another way or box (pp. 10-11).

Figure 2: Ehlers' box model. Source: Ehlers, 2006, pp. 10-11.
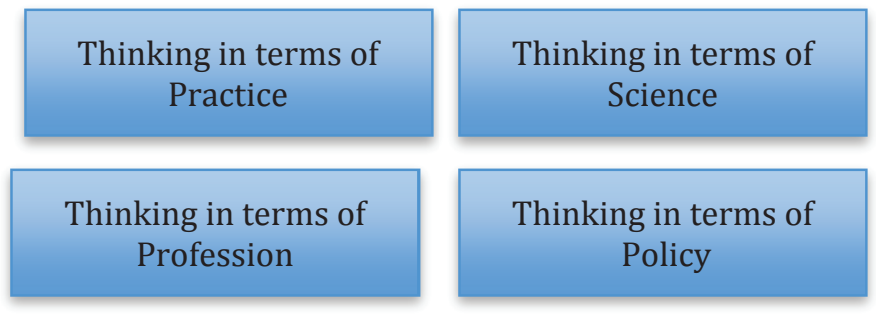
We use the model to analyse whether it is scientifically appropriate to consider India as a unit of comparison using a scientific approach, which is different from CVET policies and practice in the three countries.

\section{Review of scientific literature}

Perkin (2007) describes CVET as a phenomenon of post-industrial society or the late twentieth century with the inclusion of services as a product, followed by competitive trends to acquire the most advanced skills and expertise through intense specialisation of the workforce (Perkin, 2007, p. 41)

Alves (2007) describes CVET as essential for 'employability', making individuals more productive in the labour market (Alves, 2007, p. 60). She points out that CVET also signifies the transfer of responsibility from the state to the individual, from employment to employability, subsequently influencing economic growth (p. 59).

Heyes (2007) and McCowan (2015) analyse how CVET is becoming increasingly important in the policies of transnational actors, such as the EU and the OECD (Heyes, 2007, p. 1; McCowan, 2015, p. 3). Trampusch and Eichenberger (2012) and McCowan (2016) highlight the increasing role of non-state actors in decision-making regarding CVET because of their involvement in various settings: formal, non-formal, and informal ${ }^{4}$ (Trampusch \& Eichenberger, 2012, p. 2; McCowan, 2016, p. 506).

Trampusch and Eichenberger (2012) suggest that, apart from the market, the state and civil society are equally interested in CVET, owing to the dynamic nature of the economies since the 1990s. Thus, there currently are far-reaching consequences that underlie the relationships between the different structures and agents regarding CVET (Trampusch \& Eichenberger, 2012, p. 1).

Even though CVET has been quite popular in recent years, there are critics. Frigotto (2013, p. 390) emphasises the difference between education and qualification, claiming that education for people coming from disadvantaged backgrounds generally the focus of CVET policies - should go beyond professional training, as the latter is subordinate to the interests of the market and not those of society. Alves (2007) also claims that professional education in general is governed by the interests of capital and has been reinforcing the status quo rather than promoting real opportunities for social mobility among people coming from disadvantaged

4 This is an important feature of CVET, because unlike other education-related topics in which education may be analysed entirely within the formal framework, in this case it transcends the boundaries of formal qualifications and environment. 
backgrounds. On the other hand, Cedefop (2014) and Heyes (2007) characterise CVET policies as a requirement for engaging these groups in the economy and that it is the real key to unleash the potential of economies and build prosperous societies. Whilst presenting the case studies, it will be part of this paper to understand the conceptual foundations of CVET policies in each country: even though the terms may sound similar, a conceptual foundation based on employability can be considerably different from one based on compensatory education, just like national or provincial state-driven policies may differ in theory and practice from the rhetoric of international organisations. It will be possible to observe that in the next section, as we move on to the case studies.

\section{Case studies}

\section{CVET in Italy}

Since 1958, Italy has been a democracy, divided into 20 regions and 110 provinces. The CVET system in Italy is quite complex, organised through the state, which has exclusive legislative powers over most issues related to education. The regions have specific competences for social care and other legislative powers, but they have no authority on education and vocational training, except in projects involving the European Union (Ulicna et. al., 2013, p. 170; Refernet Italy, 2011, p. 7). The understanding of CVET in Italy is thus quite close to Cedefop's understanding of CVET. In Italy, CVET refers to training as a permanent process embedded in environments, acquired formally or informally, both inside and outside of the workplace. Therefore, it is understood as an opportunity for lifelong learning, employment and corporate innovation, career guidance, development of occupational identity, autonomy, adaptability and career management skills of the individual (Cedefop, 2015).

Italian laws (Laws 53, 107, 196, 388, and Ministerial Directive 22; Decree 13) provide further clarity on CVET provisions aiming at high employability for individuals and high productivity for the economy. The target groups for CVET policies in Italy are individuals who enter the labour market and the providers of CVET. The CVET reform integrated the vocational and academic training system with higher education and employment. CVET is essential for the evaluation of competences, non-formal and informal learning, and included in the minimum standards of service described in the national system for the certification of competencies. Italian policies favour lifelong learning and thus promote employability and social cohesion through different modalities including CVET. CVET policies 
in Italy aim to make the population employable in the entire European Union rather than just in Italy.

CVET is financed by the state (through the Ministry of Education, the regions, and the local authorities), the market (public and private agencies), and social partners apart from the EU. Joint inter-professional funds for continuing training strengthen CVET policies in Italy. Consequently, the institutional jurisdiction in the programming, management, and evaluation of the actions regarding CVET is highly specialised. Primary providers of CVET services in Italy include employers and professional associations, non-accredited training and guidance structures, universities and research institutes, upper secondary schools in collaboration with other training bodies, job centres, non-governmental organisations, and voluntary associations. CVET offerings are managed by the Ministry of Labour and Social Policies, and coordinated by regions and provinces at the local level. Some primary CVET initiatives in Italy include:

Sectoral training funds (Fondi Paritetici interprofessionale per la formazione continua) coordinated by social partners (associations and trade unions) under the supervision of the Ministry of Labour and Social Policies. The regions and provinces offer CVET.

Technical education and higher technical training is offered by the regions to (un)employed youth as a compensation for their social exclusion, aiming at their inclusion.

First and second-cycle adult education within the educational system is provided by adult education centres in public schools or autonomous educational institutions.

Apart from this, private companies provide non-formal training to their employees. However, many beneficiaries of CVET in Italy end up financing their courses on their own (ISFOL, 2009|10, p. 58). The ISFOL (Istituto per lo Sviluppo della Formazione Professionale dei Lavoratori) - now called a state institution for research, work, and social policy under the Ministry of Labour and Social Policy - which aims to promote professional qualification, social inclusion, and local development and the Leonardo da Vinci Programme, which aims at meeting the needs of education and training (run by ISFOL), are worth mentioning in the Italian context, as they form the core of CVET policy implementation mechanisms in Italy.

\section{CVET in Brazil}

Brazil is the largest Latin American country with approximately 200 million inhabitants and 26 provinces. The official language is Portuguese. The country has 
widespread social inequality, and some of the marginalised groups even lack basic citizenship and education rights. Due to the high rate of illiteracy among youth ( $8.6 \%$, i.e. 13 million people), adult education is compensatory in Brazil.

Most of the initiatives are state-driven without any engagement of the market (potential employers). In legislation, the terms 'employability' or 'competence' are rarely found. 'CVET' in not used in Brazilian policy documents, whereas 'technical vocational education and training' (TVET) and 'continuing education' are used by the Ministry of Education, similar to UNESCO's position regarding TVET.

Haddad (2007) states that the recognition of EJA (Young and Adult Education) as a right for millions of marginalised people without opportunities to complete their basic education has existed since the mid-twentieth century but that it was not until 1988 that it was legally formalised as a duty of the Brazilian state and reaffirmed in $1996 .{ }^{5}$ However, it was not integrated into policies or programmes. Sporadic initiatives based on Paulo Freire's methodology existed initially before he was extradited from Brazil during the military dictatorship period (1964-1986).

The policies regarding EJA in Brazil are still inconsistent and exclusive, benefitting only certain sections of society, leaving the needs of marginalised populations unaddressed and rendering the EJA law unfulfilled.

In the late 1990s and the early 2000s, EJA and vocational education started evolving as concrete realities in Brazil. In 1996, the national curricular guidelines for technical professional education were designed and adopted, while the National Curricular Reference Levels, approved in 2000, structured the required pedagogical details (BRASIL, 2000). This was accompanied by a wave of reforms, starting in 1995, regarding vocational education in the country to increase productivity through CVET.

In 2004, initial and continued training of youth and adults was integrated with formal high school non-technical/academic education and professional technical education.

Table 1 summarises the provision, objectives, and the key programmes identified:

5 This was reaffirmed by the 1996 Law of Guidelines and Bases of National Education. 
Table 1: Major CVET initiatives in Brazil. Source: Authors' own, based on current legislation

\begin{tabular}{|c|c|c|c|}
\hline Programme & Summary & Funding & Provision \\
\hline $\begin{array}{l}\text { Solidarity Literacy } \\
\text { Program }\end{array}$ & $\begin{array}{l}\text { Reduce illiteracy of } \\
\text { young adults }\end{array}$ & $\begin{array}{l}\text { Federal government } \\
\text { and private } \\
\text { companies }\end{array}$ & $\begin{array}{l}\text { Schools, universities, } \\
\text { city halls }\end{array}$ \\
\hline $\begin{array}{l}\text { Brazil Literate } \\
\text { Programme }\end{array}$ & $\begin{array}{l}\text { Social and } \\
\text { professional } \\
\text { inclusion of } \\
\text { historically excluded } \\
\text { individuals }\end{array}$ & $\begin{array}{l}\text { Government } \\
\text { (federal, provincial, } \\
\text { and municipal) }\end{array}$ & State-managed \\
\hline ProJovem & $\begin{array}{l}\text { Massive vocational } \\
\text { education training } \\
\text { programme for } \\
\text { the social and } \\
\text { professional } \\
\text { inclusion of people } \\
\text { under } 30\end{array}$ & $\begin{array}{l}\text { Primarily } \\
\text { government } \\
\text { (federal, provincial, } \\
\text { and municipal) } \\
\text { and private } \\
\text { organisations (e.g. } \\
\text { employers) }\end{array}$ & $\begin{array}{l}\text { Industries, selected } \\
\text { government- } \\
\text { related foundations } \\
\text { and educational } \\
\text { organisations }\end{array}$ \\
\hline ProEJA & $\begin{array}{l}\text { Massive vocational } \\
\text { and basic education } \\
\text { training programme } \\
\text { to integrate } \\
\text { professional } \\
\text { education with } \\
\text { literacy }\end{array}$ & Government & $\begin{array}{l}\text { Primarily schools } \\
\text { and universities }\end{array}$ \\
\hline Pronatec & $\begin{array}{l}\text { Technical and } \\
\text { technological } \\
\text { education } \\
\text { programme for } \\
\text { intermediate skills } \\
\text { training and IVET/ } \\
\text { CVET }\end{array}$ & $\begin{array}{l}\text { Federal government } \\
\text { and private } \\
\text { companies }\end{array}$ & $\begin{array}{l}\text { Industries, selected } \\
\text { government- } \\
\text { related foundations } \\
\text { and educational } \\
\text { organisations }\end{array}$ \\
\hline
\end{tabular}

\section{CVET in India}

With reference to the definition agreed upon in this paper, there is no concrete policy in India regarding CVET. Neither is there a concrete difference between initial and continuing VET at the policy level.

However, related or similar policy terms are used in policy documents, reports, and official papers, but they usually refer to initial VET (IVET) (Government of India, 2016, pp. 82-85). 
Goel (2011) differentiates between technical and vocational education in India, stating that whereas technical education refers to postsecondary education with practical training, vocational education requires a lower level of qualification and does not add to the qualifications of an individual (Goel, 2011, p. 3)

The term 'continuing' is used in combination with 'education' in policies to refer to VET offered as part of the literacy programmes in India to motivate nonliterates to join these programmes. Continuing education programmes in India are a temporary answer to the question 'Literacy for what?', a social policy and expenditure. They are non-formal, there is a lack of provision and providers, and there is no focus on learning outcomes or professional acknowledgement.

CVET in India, however, does exist in practice. Possibilities exist for individuals in the labour market to stop working, take up CVET, and then work again (something similar to recurrent education); to take up CVET with part-time work; to get trained by the employer (on-the-job training or in-service training) (World Bank, 2007, pp. 61-67); to be sent by the employer to a provider (refresher courses); or to go for job rotation. However, no concrete macro data is available regarding CVET in India. The lack of social security policy in the labour market except in the public sector creates no need for the collection of such data. In fact, such data might prove to be politically disastrous, just like the existing data regarding VET, labour market, and employability, which point alarmingly towards policy failure (Sharma, 2016; 2017).

CVET is ignored in the policy agenda in India due to several reasons. With only 2.3 per cent of the population receiving VET in the first place (City \& Guilds, 2015 , p. 2), it is difficult to imagine a policy regarding CVET, which refers to the advanced phase in VET.

International Labour Organisation (2017) data reveal that with an unemployment rate of 3.4 per cent, India has 17.8 million unemployed people, a figure likely to increase in the future (ILO, 2017, p. 39). Also, ILO (2016) and official Indian government data reveal that 92 per cent of the total employed population in India fall under the category of informal employment. Furthermore, 48.9 per cent of people in the labour market are employed in the primary sector, contributing only 15.4 per cent of the GDP (indicating low productivity levels and a high rate of disguised unemployment), whereas 32.3 per cent are employed in vulnerable jobs (ILO, 2016, pp. 2-3; Reserve Bank of India, 2016). The skills gap is enormous, and there is a mismatch between supply and demand in the labour market, almost on the verge of turning the Indian demographic dividend to a demographic disaster (Singh, 2015, pp. 250-255; Mehrotra, Gandhi, \& Sahoo, 2014, pp. 1-36; Rengan, 2012, pp. 171-178). 
Consequently, policy priorities include expanding the formal sector, promoting sectorial transition in the economy, and providing employment to larger number of people rather than CVET, which is left to the market and civil society by an overburdened state unable to reduce the non-development expenditure due to political reasons. Hence the focus of policies in India is quantitative rather than qualitative, and to a very large extent, CVET is a qualitative policy choice.

Since India has a large informal sector and employment opportunities for specialists are fewer compared to those for generalists and multi-takers, the return on investment on CVET is low for employers who have possibilities to hire inexpensive, inexperienced individuals rather than highly specialised professionals demanding hefty remuneration. Working conditions are not regulated for informal employees, and there is less incentive and more pressure to take up CVET with the burden of costs lying usually on the individual (except in the public sector and high-profile private sector firms and institutions, where the cost of CVET is paid by the employer).

Vocational and technical education courses are designed for IVET rather than CVET, without any acknowledgement for recognition of prior learning or even formal experiential learning. The absence of any policy or mechanism to support CVET even in combination with part-time work or short-term leave from work to acquire CVET makes it difficult and less attractive even in practice.

CVET in India is therefore not on the policy agenda, lacks macro-level data due to political and economic reasons, and is less attractive for individuals in practice due to the costs involved.

Table 2: CVET policies of Italy, Brazil, and India.

\begin{tabular}{|l|l|l|l|}
\hline $\begin{array}{l}\text { Categories of } \\
\text { comparison (based } \\
\text { on Lima and } \\
\text { Guimaries (2011) }\end{array}$ & Brazil & Italy & India \\
\hline $\begin{array}{l}\text { Political- } \\
\text { administrative } \\
\text { orientations }\end{array}$ & $\begin{array}{l}\text { Policies are } \\
\text { formulated by the } \\
\text { state with UNESCO } \\
\text { as a guiding factor }\end{array}$ & $\begin{array}{l}\text { The EU, particularly } \\
\text { Cedefop, provides a } \\
\text { framework within } \\
\text { which policies are } \\
\text { formulated and } \\
\text { implemented by } \\
\text { the state and social } \\
\text { partners }\end{array}$ & $\begin{array}{l}\text { No special CVET } \\
\text { policy; policies } \\
\text { regarding VET } \\
\text { (more focused on } \\
\text { IVET). }\end{array}$ \\
\hline Political priorities & $\begin{array}{l}\text { Compensatory } \\
\text { programmes for } \\
\text { social inclusion }\end{array}$ & $\begin{array}{l}\text { Employability and } \\
\text { productivity }\end{array}$ & Not applicable \\
\hline
\end{tabular}




\begin{tabular}{|l|l|l|l|}
\hline $\begin{array}{l}\text { Categories of } \\
\text { comparison (based } \\
\text { on Lima and } \\
\text { Guimaries (2011) }\end{array}$ & Brazil & Italy & India \\
\hline $\begin{array}{l}\text { Organisational } \\
\text { and administrative } \\
\text { dimensions }\end{array}$ & $\begin{array}{l}\text { Primarily state, } \\
\text { participation }\end{array}$ & $\begin{array}{l}\text { State, market, civil } \\
\text { society }\end{array}$ & Not applicable \\
\hline $\begin{array}{l}\text { Conceptual } \\
\text { elements }^{*}\end{array}$ & Social & Economic & Not applicable \\
\hline
\end{tabular}

* These rows represent dimensions relating to policies rather than practice and cannot be used to describe data from practice.

Source: Created by authors based on a cumulative analysis of information available from different sources used in this paper.

Table 2 shows the dimensions of the case studies according to the policy analysis framework by Lima and Guimarães (2011). Evidently, there are far more differences than similarities between the case studies. When it comes to the politicaladministrative dimension, there are three different types of CVET policies: one as part of a national strategy and not particularly described (India), another one led by the government with transnational influences but also not explicitly identified as CVET (Brazil), and one that responds to a transnational discourse (Italy). These differences also affect the following dimensions, especially the political priorities of CVET policies. In India, the other dimensions are not applicable due to the characteristics of the policy analysis when applied in that context. This shows a direct connection with Egetenmeyer's (2017) transnational contexts dimension of what should be considered when analysing policies. The Brazilian context of focusing adult education on compensatory initiatives also has a role in its political priorities, as the main argument is to enable social inclusion. In Italy, the policies are aligned with Cedefop (2014), using the same vocabulary.

The last two dimensions complete the consistent difference between the three countries analysed. Whilst Indian policies remain non-applicable to the comparative framework, Brazil's CVET policy argument is more social-driven and led by the state, whilst Italy has a more economically driven strategy featuring a higher level of collaboration among different stakeholders. 


\section{Discussion}

The context for comparing how CVET policies are (not) formulated in Italy, Brazil, and India is the economy and particularly, the labour market, the employment situation, and the nature of economic activities. Below is a summary of our findings.

\section{How is CVET policy (not) formulated in Brazil, Italy, and India?}

Transnational influences are evident only in the case of Italy, whereas in Brazil and India, the primary role of the national government in policy formulation is evident. In Brazil, the state is the primary provider; in India, the market and civil society are active; whereas in Italy, all three sectors - state, market, and civil society -are active. There is a huge gap in India between policy and practice, because even though CVET policy is non-existent, CVET does exist in practice.

In Italy, CVET is an economic policy, as in most other European Union member states, whereas in Brazil, it is a social policy. The focus in Brazil is on input or curricula whereas in Italy, the focus is on learning outcomes. In the case of India, the practice of CVET leads to a focus on learning outcomes as well, thus making it fundamentally different from educational provisions that focus on input and are a primarily a part of social policy.

CVET is not used as a policy term in Brazil and India. It is a transnational policy term and has been used by the European Union, particularly Cedefop, influencing Italian policies. Although there are mentions of TVET - a clear influence of UNESCO - in Brazil, the idea of continuing and initial VET, as referred to in this paper, is not truly recognisable in this case or in the Indian case.

\section{Why are CVET policies (not) formulated in Brazil, Italy, and India?}

CVET is used by the European Union and Cedefop to describe and formulate policies regarding the specialisation and optimisation of the productive capability of the invested resources (including the workforce) because of the European Union's highly structured and organised economy. Italy follows the model to harness the vast opportunities for growth, employment, and employability but at the same time, it monitors the quality of CVET through benchmarking and an open method of coordination to keep it from dropping below a certain level. In the cases of Brazil and India, transnational influences are limited. Consequently, there is neither an imposing framework within which the two countries formulate policies nor any check to prevent the absence of policy mechanisms for optimised productivity and overall development through CVET. Italy is more integrated 
transnationally, driven by economic considerations, whereas Brazil and India, for political reasons, adhere to a stronger nation-state model.

As a consequence, policy priorities and contexts are different in Italy, Brazil, and India, resulting in advanced CVET policies in Italy, a weak CVET policy Brazil, and no policy in India. As a consequence, Italy has a higher level of productivity with mobility opportunities across the EU, whereas Brazil and India are struggling with low productivity and the wastage of resources.

\section{Conclusion}

The discussion leads us to some scientific reflections about the choice of units for comparison. The authors chose the three countries to initiate a deep discussion about the units of comparison. The arguments by Ehlers (2006) and Egetenmeyer (2017) make it clear that adhering to pre-defined categories cannot qualify India as a unit of comparison for comparative studies in scientific research. Neither are predefined comparative categories relevant for all research questions.

Even though CVET exists in practice in India, it lacks a specific policy. It would therefore be scientifically inappropriate to include India as a unit of comparison. Policy cannot be equated with practice from a scientific perspective. Policy is different from practice in terms of objectives, scope, nature, process, outcomes, and most importantly, approach.

This discussion is more methodological and refers to the difference between what could be compared and what could not be compared scientifically. The assumption that the units of comparison should be similar enough to be compared and to be similar or different (Singh, 2017, pp. 298-299) underlines the fact that India is not scientifically comparable regarding CVET policies.

The comparability of Indian policies might increase in the future as it gets more integrated into the global economy. The problem of low productivity in India and Brazil raises questions about the lack of CVET policies in India and the social orientation of CVET policies in Brazil. Both need to reconsider and change their stance. However, whether Brazil and India follow the EU model or develop their own competitive models as BRICS countries or individual states cannot be predicted at this time.

For comparing provisions different or similar, designing suitable contexts to answer research questions and formulating categories of comparison accordingly make comparative studies more systematic, scientific, and fruitful. 


\section{References}

\section{Scientific references}

Alves, Natália: "E se a melhoria da empregabilidade dos jovens escondesse novas formas de desigualdade social?" Sísifo. Revista de Ciências da Educação, 2, Instituto de Educação: Lisboa 2007, pp. 59-68.

Bray, Mark / Thomas, R. Murray: "Levels of comparison in educational studies. Different insights from different literatures and value of multilevel analysis". Harvard Educational Review 65(3), 1995, pp. 472-490.

Cedefop. Tissot, Phillipe: Terminology of European Education and Training Policy. Publications Office of the European Union: Luxembourg 2014, pp. 1-247.

Cedefop. CVET in Europe. The way ahead. Cedefop Reference Series. Publications Office of the European Union: Luxembourg 2015, pp. 1-120.

Charters, Alexander N./ Hilton, Ronald J. (eds.): Landmarks in International Adult Education. A Comparative Analysis. Routledge: London 1989.

Egetenmeyer, Regina: "What to Compare? Comparative Issues in Adult Education" In: Slowey, Maria (ed.): New Perspectives on Comparative Adult Education. Florence University Press: Florence 2017, pp. 89-126.

Ehlers, Søren: "Four Danish Strategies Towards Adult Learning”. In: Ehlers, Søren (ed.) Milestones Towards Lifelong Learning Systems. Danish University of Education Press: Copenhagen 2006, pp. 1-17.

Frigotto, Gaudencio: "Fazendo pelas mãos a cabeça do trabalhador. O trabalho como elemento pedagógico na formação professional". Cadernos de Pesquisa (47), 2013, pp. 38-45.

Gadotti, Moacir: História das ideias pedagógicas. 8th edition. Série Educação: São Paulo 1979.

Goel, Vijay P.: Technical and Vocational Education and Training (TVET) System in India for Sustainable Development. UNESCO-UNEVOC International Centre for Technical and Vocational Education and Training: Bonn 2011, p. 3, retrieved 14.05.2017 from http://www.unevoc.unesco.org/up/India_Country_Paper.pdf.

Haddad, Sérgio: "A ação de governos locais na educação de jovens e adultos". Revista Brasileira de Educação 12(35), 2007, pp. 197-211.

Heyes, Jason: "Training, social dialogue and collective bargaining in Western Europe". Economic and Industrial Democracy 28 (2), 2007, pp. 239-58.

King, Kenneth: A Technical and Vocational Education and Training Strategy for Unesco. Background paper prepared for Unesco, United Kingdom 2009, retrieved 15.05.2017 from http://www.unevoc.unesco.org/fileadmin/user_up load/docs/A_Technical_and_Vocational_Education_and_Training_Strategy_ for_UNESCO._Background_Paper_by_Kenneth_King.pdf. 
Lima, Licinio C. / Guimarães, Paula: European Strategies in Lifelong Learning. A Critical Introduction. Budrich: Leverkusen 2011.

McCowan, Tristan: "Should universities promote employability?" Theory and Research in Education 13(3), 2015, pp. 267-285.

McCowan, Tristan: "Universities and the post-2015 development agenda. An analytical framework". Higher Education 72(4), 2016, pp. 505-523.

McQuaid, Ronald W. / Lindsay, Colin: “The concept of employability”. Urban Studies 42(2), 2005, pp. 197-219.

Mehrotra, Santosh / Gandhi, Ankita / Sahoo, Bimal K.: "Is India's TVET System Responding to the Challenge of Rapid Economic Growth?” In: Mehrotra, Santosh (ed.): India's Skill Challenge. Reforming Vocational Education and Training to Harness the Demographic Dividend. Oxford University Press: New Delhi 2014, pp. 1-36.

Perkin, Harold: “The history of universities." In: Forest, James J.F. / Altbach, Philip G. (eds.): International Handbook of Higher Education. Springer: London 2007, pp. 159-205.

Refernet Italy: Italy: VET in Europe.Country Report 2010. Publications Office of the European Union: Luxembourg 2011.

Rengan, Venkatram: "Vocational Education and Training System (VET) in India." In: Pliz, Matthias (ed.): The Future of Vocational Education and Training in a Changing World. VS Verlag für Sozialwissenschaften: Germany 2012, pp. 171-178.

Singh, Shalini: "India Towards a Knowledge Economy. Alternatives for the Global Demographic Challenge and Inclusive Development in India”. In: Egetenmeyer, Regina (eds): Adult Education and Lifelong Learning in Europe and Beyond: Comparative Perspectives from the 2015 Würzburg Winter School. Peter Lang: Frankfurt a.M. et al. 2015, pp. 237-260.

Singh, Shalini: "Transnational Comparative Studies as Sources for Research," Conference Proceedings, 6th ISCAE Conference at Julius-Maxilian University Würzburg 15-18 February 2017, Julius-Maximilian University of Würzburg: Germany 2017, pp. 289-300.

Trampusch, Christine / Eichenberger, Pierre: "Skills and industrial relations in coordinated market economies. Continuing vocational training in Denmark, the Netherlands, Austria and Switzerland". British Journal of Industrial Relations 50(4), 2012, pp. 644-666.

Ulicna, Daniela / Curth, Annette: “Country Report Italy". In: Ulicna, Danlie / Curth Annette: Study on Quality Assurance in Continuous VET and on Future Development of EQAVET. ICF GHK: Brussels 2013, pp. 170-175. 


\section{Empirical references}

Constituição da República Federativa do Brasil. Brasília, DF: Senado 1988.

Ministry of Education: Referenciais Curriculares Nacionais da educação Profissional de Nível Técnico. Brasília: PROEP 2000.

Cedefop: CVET in Europe. The Way Ahead. Publications Office of the European Union: Luxembourg 2015.

City \& Guilds Group: The Economic Benefits of Vocational Education and Training in India. City \& Guilds Group: London 2015, retrieved 14.5.2017 from https:// www.cityandguildsgroup.com/ /media/CGG\%20Website/Documents/CG GroupIndia\%20pdf.ashx.

Italian Decree 13 of 16.01.2013: "Definition of general rules and essential performance levels for the identification and validation of non-formal and informal learning and the minimum standards of service of the national certification system." Gazzetta Ufficialen 39, 2013

Government of India: National Policy on Education 2016. Report of the Committee for Evolution of the New Education Policy. Ministry of Human Resource Development 30.4.2016, pp. 82-85.

ILO: India Labour Market Update. ILO Country Office for India: New Delhi, 2016, pp. 2-3, retrieved 14.5.2017 from http://www.ilo.org/wcmsp5/groups/public/--asia/---ro-bangkok/---sro-new_delhi/documents/publication/wcms_496510.pdf.

ILO: World Employment Social Outlook. Trends 2017. International Labour Office: Geneva 2017.

ISFOL (2015) XVI Rapporto sulla Formazione continua, Annualità 2014-2015.

ISFOL (2009|10)."Structures of Education and training systems in Europe: Italy". In: Italian Eurydice Unit: Florence.Law 236 of 19|06|1993.,"Urgent interventions in support of employment " published in: GazzettaUfficiale, n.203 of 30-8-1993 - Ordinary Supplement n. 82.

Konrad Adenauer Stiftung / FICCI: "Policy Frameworks". In: Skill Development in India 2015, pp. 6-8, retrieved 14.5.2017 from http://www.kas.de/wf/doc/ kas_42848-1522-2-30.pdf?151016072126.

Italian Law 196 of 24.07|.1997, Article 17: "Employment promotion standards". Gazzetta Ufficiale 154, 1997.

Italian Law 53 of 08.03.2000: "Provisions for the support of maternity and paternity, for the right to care and training and to coordinate city hours". Italian Republic, General Series No. 60 of 13.3.2000, pp. $3 \mathrm{ff}$.

Italian Law 388/00, Article 118: "Interventions in the field of vocational training as well as provisions on activities carried out in Community funds and the European Social Fund". Gazzetta Ufficiale 302, 2000. 
Italian Law 107 of 13.07.2015: "Reform of the national education and training system and delegation for the reorganization of existing legislative provisions". Gazzetta Ufficiale 162, 2015.

Ministerial Directive 22 of 06.02.2001: “On Adult Education”. Italian Republic 123, 2001. Ministry of Education No. 455 of 29|.07.1997, Adult education - education and training.

Ministry of Education: Lei no. 9.394, de 24 de dezembro de 1996. Estabelece as Diretrizes e Bases da Educação Nacional. Legislação Básica. 2a ${ }^{a}$ Ed. Brasília: PROEP 1996.

OECD: OECD Skills Strategy Diagnostic Report: Portugal. OECD: Paris,2015, pp. $1-180$.

Reserve Bank of India: “Table 163: Employment Situation in India - per 1000 Distribution of Usually Employed by Broad Groups of industry for Various Rounds". In: Reserve Bank of India (ed.): Handbook of Statistics on Indian Economy 2015-16. Reserve Bank of India: New Delhi 2016, retrieved 14.5.2017 from https://rbidocs.rbi.org.in/rdocs/Publications/PDFs/TABLE163C9C46 E9900DF49B6AF55D6BBE4384291.PDF.

The World Bank: Skill Development in India. The Vocational Education and Training System. The World Bank: Washington, D.C. 2007, pp. 61-67.

Sharma, Jeevan Prakash: "PM's Skill India initiative scores low on placements". Hindustan Times, 1.6.2016, retrieved 14.5.2017 from http://www.hindustan times.com/india/pm-s-skill-india-initiative-scores-low-on-placements/story0oU24Izpqb7JHSCjpudXUJ.html.

Sharma, Jeevan Prakash: "Govt's Skill India programme off to a dodgy start; possible fraud enrolment". Hindustan Times 2.3.2017, retrieved 14.5.2017 from http://www.hindustantimes.com/india-news/govt-s-skill-india-programmeoff-to-a-dodgy-start-possible-fraud-enrolment/story-UCzLsPJjplQg5jlg WOBuPP.html.

\section{Websites}

Brazilian Ministry of Education: Current EJA legislation, retrieved 01.05.2017 from http://www.ceeja.ufscar.br/legislacao-vigente-para-a-eja.

Brazilian Ministry of Education: Archive of files and legislation, retrieved 29.04.2017 from http://portal.mec.gov.br/cne/arquivos/pdf/CEB011_2001.pdf.

Brazilian Ministry of Education: Current EJA programmes, retrieved 23.04.2017 from http://portal.mec.gov.br/secretaria-de-educacao-basica/programas-eacoes? id=17462. 
Regina Egetenmeyer and Monica Fedeli - 978-3-631-73704-0

Downloaded from PubFactory at 01/11/2019 10:08:46AM

via free access 


\section{Transnational Perspectives on Lifelong Learning Policies}


Regina Egetenmeyer and Monica Fedeli - 978-3-631-73704-0

Downloaded from PubFactory at 01/11/2019 10:08:46AM

via free access 
Reinhard Lechner, Mari Liis Räis, Nitish Anand, Ahmet Murat Yetkin \& Paula Guimarães

\title{
The influence of PIAAC results on (inter-)national adult education policy: A critical discussion of Austria and Estonia
}

\begin{abstract}
This article compares and analyses the results of the Programme for the International Assessment of Adult Competencies (PIAAC) in Austria and Estonia, as well as the reaction to these results in national adult education policies and in the scientific community. By the comparison, tendencies of an international influence can be recognised, namely the influence of human resources management guidelines in national policies.
\end{abstract}

\section{Introduction}

In 2012, the Organisation for Economic Cooperation and Development (OECD) performed several rounds of surveys of the Programme for the International Assessment of Adult Competencies (PIAAC). 23 European countries took part in this evaluation of adults' (16-65-year-olds) basic functional learning skills for workplace and everyday problem-solving in literacy, numeracy, and information and communication technology. The results fostered political discussions in these countries' national political institutions, and adult education scholars responded to the ranking of competencies.

Stressing policy on the national and European level, this article analyses and compares the results of the PIAAC surveys carried out in Austria and Estonia. After presenting and discussing selected data on the socio-economic background of the two countries, we compare the results and their impact in Austria and Estonia concerning policy reactions and reactions by adult education scholars. Given the similarities and differences of the two countries, the research question is: How has PIAAC influenced adult education policy in Austria and Estonia?

To answer the question and to accomplish a comparison, it is important to understand the main idea behind the OECD's development goals concerning adult education policy. As a second step, we address some methodological aspects about comparisons. Further, we take account of the methodological conditions of comparison concerning cultural similarities and differences of adult learning in different countries. We then present and compare selected PIAAC results from 
Austria and Estonia and discuss responses of relevant parties. As a conclusive statement to these results, we point out some discursive and methodological aspects of PIAAC that need to be researched further.

\section{Lifelong learning according to the OECD}

The OECD aims at promoting the economic and social well-being of people around the world (OECD, 2017). It is primarily concerned with economic policy. However, education has taken on increasing importance within that mandate: education has been reframed as central to national economic competitiveness and linked to an emerging 'knowledge economy' (Grek, 2009, p. 24). The success of OECD in shaping the public discussion on education policies in Europe can be assessed through surveys in national education systems and the international comparison of their results, such as PIAAC, even if national differences can be noticed (Jakobi, 2012). According to Jones (2007, p. 94), '[s] ince the middle of the last century, international organisations have been increasingly playing an influential role as "purveyors of ideas" and as leading participants in the struggle over education policy content'. One of the main ideas brought to the political discussion by international organisations like OECD is lifelong learning (Field, 2006). In recent definitions, the term stresses the role of the individual, who is primarily responsible for his or her education and training. Additionally, individuals have to learn over the whole life span in order to be able to participate in the everyday workplace and social life and to cope with fast changes (Field, 2001).

Lifelong learning was first adopted by the OECD in the 1990s (Rubenson, 2015), and in 2002, education and training became the main issue of a separate directorate. Since then, strategies to influence education and training policies have been made more visible, for instance with the Programme for International Student Assessment (PISA). The Survey of Adult Skills of the Programme for the International Assessment of Adult Competencies (PIAAC) is an initiative of the directorate, designed to assist governments in assessing, monitoring, and analysing the level and distribution of skills among their adult populations. It is referred to as 'an unparalleled source of evidence for policy makers' (OECD). PIAAC is directed at providing internationally comparable data on key skills under three domains: numeracy, literacy, and problem solving in technology-rich environments. It allows for comparing statistical data on adult education for many different countries. Up until now, PIAAC includes three rounds of data collection: 2008-2013, 2012-2016, and 2016-2019.

As critics point out, the OECD has favoured an economistic approach to lifelong learning (Rubenson, 2015). National education and training systems are 
understood as crucial factors in improving economic growth as well as the prosperity of individuals and society. PIAAC helps to find key cognitive skills and workplace skills based on the idea that there can be a mismatch between education and training and the needs of the economy, thereby pushing nations into policy reforms for the attainment of desired results. Therefore, PIAAC allows more accurate measurement of the stocks of human capital than standard and traditional indicators of educational attainment, years of work experience, and occupational classifications. In this sense, PIAAC may help to identify areas where the greatest growth returns are likely to be had for different overall education and training investment strategies. As such, it can be understood as 'governing by numbers' (Ozga \& Lingard, 2007, p. 69) in order to foster competitiveness and growth of the economy (Grek, 2010).

\section{Theoretical framework for analysis and comparison}

The analysis and the comparison of PIAAC results in Austria and Estonia will be discussed according to three social policy analytical models referred to by Lima and Guimarães (2011). The first model - the democratic emancipatory model - is based on polycentric education and training systems in a framework of participatory democracies characterised by a range of social struggles and conflicts. Policies tend to favour decentralisation and bottom-up dynamics, to the detriment of top-down ones. State programmes prefer local support for self-governing and self-managed projects and activities, promoted by civil society organisations, particularly non-profit ones, and social movements. The priorities of adult education policies are to construct more inclusive, just, egalitarian, democratic, and participatory societies, in which all the action of all the social actors matters. Social, economic, and political change is an essential purpose; education and training are regarded as empowering processes, mechanisms for social emancipation and basic social rights.

The second model - the modernisation and state control model - includes guidelines that are geared towards valuing education and training as support for social and economic modernisation. In this context, the state is a key player in defining and providing education, and its intervention in ensuring free education for all is essential. These guidelines set out to plug the gaps and social and educational needs of people singled out by various government departments. In addition, adult education and lifelong learning, especially the basic and vocational components, help to train citizens and workers, fostering social, civic, and political participation within the framework of formal public authorities and labour organisations. The policy priorities emphasise basic education projects and initiatives, namely 
functional literacy, adaptive literacy, and second chance education (such as evening courses for adults).

Finally, in a third model - the human resources management model - profitmaking organisations are central and the individual is seen as a rational, strategic actor. The policy priorities preferred in this model are driven by economic growth through increased productivity, competitiveness, and employability of working adults, since education and training are at the service of the development of human capital. Adult education is concerned with social, economic, and educational adaptation, where citizens are regarded as enjoying freedom of choice and being responsible for their education and training options. Education and training (in formal, non-formal, and informal forms) are gaining market value since they can be translated into investments with an economic return.

\section{Comparing PIAAC results in Austria and Estonia}

\section{Methodological considerations}

With a population of 8.6 million and 1.3 million, respectively, Austria and Estonia belong to the smaller members of the European Union. Both countries have several qualities in common and hence can be compared internationally (Reischmann, 2008): Both are rather small countries belonging to the European Union with developed, albeit differing adult education systems. Additionally, Austria and Estonia are active members of the OECD in the sense that they are some of the fastest growing skill-based economies with well-developed adult educations systems and high rates of lifelong learning participation (Eurostat 2017). Considering adult education policy commonalities and differences in the developments of the two countries, we therefore aim to describe the instances where PIAAC has been part of policy development and to provide explanations for the differences in the countries' responses.

Having in mind that 'care is needed in reading reports of international surveys' (Evans, 2014) and considering the difficulties and problems of international comparison, the research question is directed at identifying and interpreting similarities and differences in terms of how the PIAAC results influenced Austria's and Estonia's adult education policy and how these results reflect characteristics of the analytical models. We hypothesise that there are tendencies of an international influence of PIAAC on adult education policy. We will try to show this using methodological guidelines proposed by Reischmann and Bron Jr (2008). Accordingly, the comparison should focus on interpreting lifelong learning and adult education in a way in which one or more aspects in two or more countries 
are compared' (Reischmann, 2008, p. 9). The criteria established for our analysis with an emphasis on comparison include: a) main conclusions from the PIAAC results from a national (Austrian and Estonian) point of view; b) national political reaction referring to the definition and development of lifelong learning and adult education policies and programmes; c) reception by researchers, including the discussion that developed based on the PIAAC results at the national level. These criteria were established due to their relevance for understanding the influence of PIAAC results in Austria and Estonia.

Data were collected separately for the two countries, using written sources such as policy documents, research reports, and public statements of officials in the media; the main criterion for data collection was their relevance to the PIAAC study or its results. The gathered data had to be either in English or in the official languages of the countries. The selected data was analysed using content analysis, a research technique that 'seeks to analyse data within a specific context in view of meanings someone attributes to them' (Krippendorf, 1989, p. 403). Thereafter, the two countries are compared by highlighting the similarities and differences in their education policies to show tendencies of an international influence of PIAAC and the extent to which characteristics of the abovementioned policy analytical models apply.

\section{Data discussion}

\section{Austria}

For the analysis of Austria's results, a main database was the Statistik Austria report (Statistik Austria, 2013). Its data as well as public documents and research papers were analysed according to the three models (Lima \& Guimarães, 2011).

The most important PIAAC results were: Austrian adult learners showed above average competences in daily life mathematics; they are under average in literacy tasks and average in dealing with digital competence (Statistik Austria, 2013, p. 71). The results showed that persons with low formal education, especially non-native speakers of German, unemployed people and older people had lower basic and workplace competences and did not take part in adult education as frequently (Gruber \& Lenz, 2016, p. 88). These results confirmed a status quo of Austrian adult education and problems still to solve. A closer view showed some in-depth results (ibid.): Only 8.4 per cent of adults in Austria reached the highest levels of literacy competence in PIAAC. At 11.8 per cent, the OECD average was significantly higher. About one million adults in Austria had problems reading and understanding different kinds of texts. About 11.4 per cent scored low in all of the 
three tested competencies. This risk group included especially older people and women, who presented deficits in basic mathematics and in digital competencies.

The political reaction in Austria to the PIAAC results was on the one hand optimistic, as Austria's numeracy results were above the OECD average and its digital skills were average. On the other hand, it was concerned, as Austria's literacy skills were below average. Schmied, Austrian's minister of education in 2013, stated that Austria was on track with reforming the national education system towards a more comprehensive system that fosters lifelong learning. She emphasised the importance of early interventions in language learning at kindergarten and elementary school, the expansion of all-day schools, the provision of basic skills for migrants and educationally disadvantaged people, and the possibility to improve educational attainment through adult education (Bundesministerium für Bildung, 2015).

Since 2011, Austria has followed a 'Strategy to Support Lifelong Learning in Austria - LLL: 2020' (Knett, 2014,p. 104), which includes goals of modernisation and state control as well as human resources management guidelines (Lima \& Guimarães, 2011). The strategy was approved by the federal government, and the ministries were entrusted with its implementation. Some of the action items from this lifelong learning strategy are similar to the OECD's 'central approaches for policy-making' (Knett, 2014, p. 108). With the present PIAAC results, it became clear that many of the OECD policy approaches related to PIAAC were also central for LLL: 2020. New tasks to be performed involve the following: a comprehensive school system of lifelong learning; the transfer of learning results to the economy; accessible further education opportunities for educationally disadvantaged people; and the recognition of non-formal knowledge (Knett, 2014, p. 108). From the ministry's reaction to PIAAC and the adjustment of the LLL strategy, it is evident that Austria's adult educational policy follows an economistic approach based on human resources management characteristics (Lima \& Guimarães, 2011).

Researchers voiced a more pessimistic view on PIAAC. Titelbach criticised the validity of the results, stating that literacy skills - in terms of writing and interaction - could hardly be researched using standardised international surveys like PIAAC (Titelbach, 2014, p. 45). He also noted the restricted validity of PIAAC in terms of measuring the individual and collective economic outcome of a country, especially when comparing it to another.

For Schmid, Tölle, Steinklammer, and Lichtblau (2014), PIAAC was a warning sign for Austria to take its problems with illiteracy and basic competencies more seriously (p. 114). As the results showed, about one million people had trouble reading a text and understanding its content. Furthermore, many of these 
people only had a lower school degree, a low income and tended to be older people, women, and migrants (p. 114). Schmid et al. underline the necessity to start literacy in kindergarten; furthermore, they argue that primary schools need to do more team teaching and literacy intervention; adult education needs to offer more low-threshold classes for educationally disadvantaged people to cope with the problem.

Knett points to the ongoing international competitiveness of Austria's companies, asking whether PIAAC really matters for them. Nevertheless, he stressed the importance of the PIAAC key competences for shaping a sustainable knowledgebased society and economic prosperity. He also believes that Austria's strategy LLL: 2020 is a good base to be implemented courageously (Knett, 2014, p. 104). Regarding the three analytical models, the criticism by Austria's researchers reveals a more humanistic view towards a democratic model on adult education policy.

\section{Estonia}

Estonia's results for functional literacy and numeracy (both above OECD average) were found to be satisfactory, but problem-solving in ICT-rich environments was somewhat disappointing (Halapuu \& Valk, 2013, p. 8), especially considering the importance of such competences for the labour market following a human resources management trend (Lima \& Guimarães, 2011). Altogether, two major issues were raised in response to the results: ICT proficiency and a skills mismatch among older adults. ICT skills are seen as important basic skills for participation in Estonian society, because the country has some of the most advanced Internet-based systems for interacting with public and private institutions. From this perspective, it is very worrisome that large parts of the population lack these ICT skills (Halapuu \& Valk, 2013, p. 130), reflecting concerns related also to the modernisation and state control model characteristics (Lima \& Guimarães, 2011).

Another problematic issue was the loss of skills over time. While young people perform very well on the literacy and numeracy tests, older people tend to 'lose' the skills over time. This is related to the fact that Estonia also ranks high in overeducation, especially among older adults. A likely cause for this are the sweeping changes in the labour market since re-independence, which have made some previously widespread occupations (and the related education) redundant. Therefore, the critical issue is mismatch between skills and labour market needs, which could be addressed by increasing adult education and training for these groups, revealing human resources management concerns (Lima \& Guimarães, 2011). PIAAC also showed that Estonians wish to participate in adult education more often than the OECD average (Saar, Unt, Lindemann, Reiska, \& Tamm, 2014). 
Based on a review of the major news outlets at the time, the reaction to the publication of these results was modest. The PIAAC results were mainly promoted and discussed by the ministry itself. The ministry also tendered research reports based on the PIAAC data, which are available to all on the ministry's website (see also Ministry of Education and Research, 2015). The results were presented publicly at a conference in 2015 and it was broadcast over the Internet (Postimees, 2015), but no significant public discussion followed. This can be attributed to the mostly uncontroversial nature of the results.

Since the publication of first results in 2013, a number of policy documents have been put into action. The most important of these is the Lifelong Learning Strategy 2020, which guides the entire field of educational policy. The influence of PIAAC is clearly visible in the recent documents, even though there are few direct references. The clearest link can be seen in how well the aims of the lifelong learning strategy and its programmes are in concordance with the OECD (and $\mathrm{EU})$ guidelines and aims in accordance to human resources management orientations (Lima \& Guimarães, 2011). The main priorities of the current LLL strategy include (Estonian Government, 2014):

1. change in the approach to learning,

2. competent and motivated teachers and school leadership,

3. the concordance of lifelong learning opportunities with the needs of the labour market,

4. a digital focus in lifelong learning,

5. equal opportunities and increased participation in lifelong learning.

The strategy is accompanied by programmes that specify the actions to be taken. The strategy's programmes for achieving the main goals of adult education (Estonian Minister for Education and Research, 2016b) are all in line with the EU's general target to increase participation in adult education by including disadvantaged groups and increasing access to different types of education. The programme references PIAAC directly, saying that the PIAAC study showed that people who do not speak the official language have less security on the labour market and need to develop vocational skills alongside language skills (ibid, p. 8).

The programme for the concordance of labour market needs and education includes the target of participating in the next round of the PIAAC survey to assess the results of the LLL strategy programmes (ibid, p. 13), thereby indicating human resources management characteristics (Lima \& Guimarães, 2011). The programme text also states that participation in the survey must be followed by indepth analysis along with policy recommendations that address skills, education, and their use on the labour market. The programme for competent and motivated 
teachers is also based on the PIAAC input, as mentioned in a previous thematic analysis of teachers' skills according to PIAAC (Valk, 2013, p.1).

The influence is likely wider than can be deduced from public documents: it cuts across multiple policy fields (labour market, education, and communications) and is often implicit rather than explicit. Multiple ministries are involved in providing adult education in specific fields with the clear aim to a) increase participation in adult education and training and b) increase the supply of specific skills needed on the labour market (Estonian Minister of Education and Research, 2016; Estonian Minister of Economic Affairs, 2015). This can all be linked to the international influences as well as to the PIAAC results. It is difficult to distinguish the influence of the OECD agenda from the EU influence on policy development, but there is no doubt that it has been significant.

Figure 1: Main PIAAC results for Estonia and Austria.

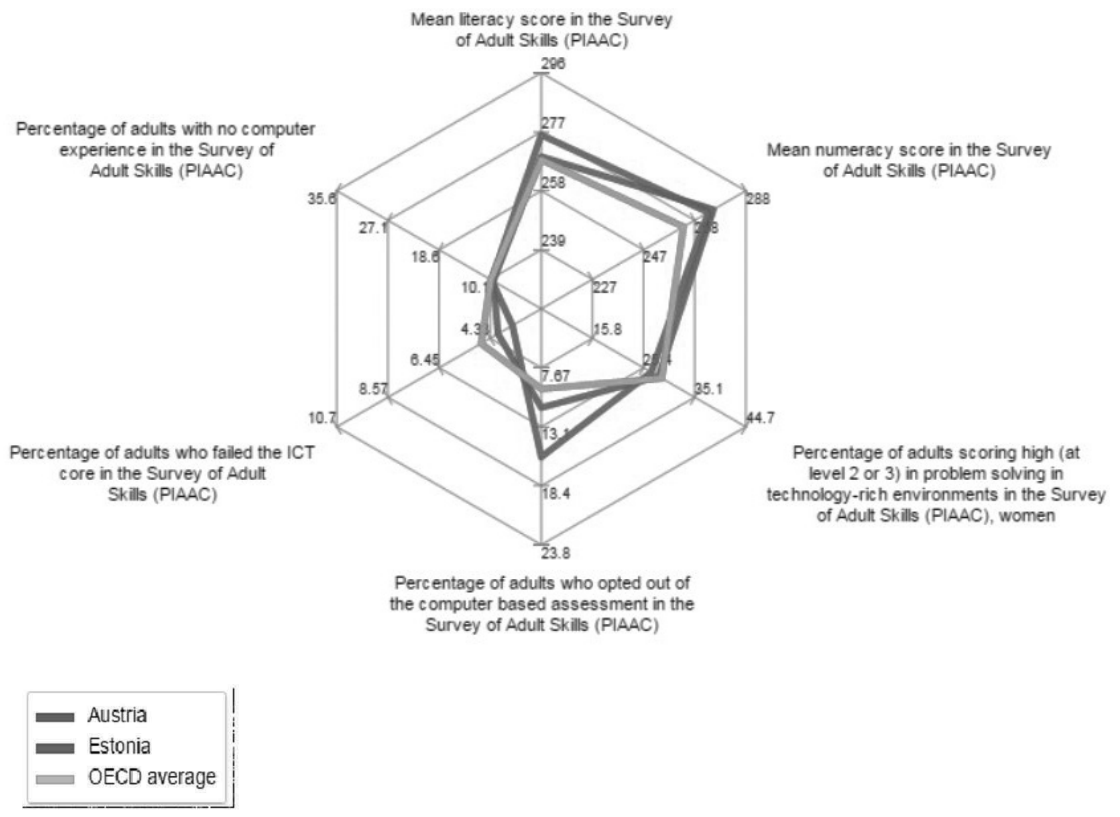

Source: OECD Education GPS, 2017, compiled by authors 


\section{Comparison}

\section{Similarities}

Both Austria and Estonia have elaborate systems of adult education, which are partly state-financed and guided by scientific principles. The systems cooperate with the national ministries, the universities, and business organisations, and they are responsive to the European Union's education policy guidelines. As EU members, both countries follow the European Commission's Programmes of Lifelong Learning, which have guidelines that can be easily related to OECD and PIAAC aims (Bieber \& Martens, 2011).

In PIAAC, both Austria and Estonia ranked above the OECD average. Although Austria reached good results in numeracy and satisfying results in digital literacy, the national results in literacy were disappointing. Estonia was satisfied with adults' performance in literacy and numeracy but disappointed with results in ICT skills. After PIAAC, the countries put efforts into reframing their existing education policies according to these results. A common consequence was the emphasis on adult education in the national LLL 2020 strategy goals. Both Austria and Estonia focused on a human resources management strategy stressing a) the need for concordance between school education and labour market needs, b) better support of disadvantaged groups like migrants or older people, c) development of a comprehensive system of lifelong learning, and d) the need for making informal learning results more visible.

In Austria and Estonia, the PIAAC results were mainly promoted by the ministries of education, which dictated the public discussion around the subject. Both ministries ordered research reports based on the PIAAC data, showing great interest in the practical use of this data. In Austria, Statistik Austria was responsible for the report (Statistik Austria, 2013). In Estonia, reports were prepared by researchers at public and private research institutions as well as compiled by the ministry itself. Although the official reaction was quite positive in both countries, the researchers asked some critical questions about what was being measured (Halapuu \& Valk, 2013) and highlighted the analytical limitations of the data (Anspal, Järve, Jürgenson, Masso, \& Seppo, 2014, p. 87; Titelbach, 2014, p. 45).

Both countries also lacked a significant public discussion, as the main economic actors and other interest groups remained silent. This can in part be attributed to the ambiguity and versatility of the adult education field, where it is difficult to identify the 'responsible' parties. Although the PIAAC results showed important tasks for Austria to be developed in the future - tasks that also concern the job market - there were no reactions from the business community. One possible 
reason might be Austria's nevertheless satisfying economic growth, which gives companies a feeling of safety (Knett, 2014, p. 105).

Currently, attention has been turned towards disadvantaged groups in both systems (e.g. migrants in Austria; older people and non-Estonian speakers in Estonia). Different target groups require special attention to their specific skills deficits. With this task in mind, both countries are working towards improving their adult education systems (Estonian Minister for Education and Research, 2016b; Schmid et al., 2014).

\section{Differences}

Like the OECD, Austria and Estonia consider skills and competencies to be systematically learnable, measurable, and of high practical use, which is why they are of importance for the labour markets in both countries. From among our analytical models, human resources management seems to be dominant here (Lima \& Guimarães, 2011). Aligning people's skills and the needs of the labour market has become a high priority. However, differences in the reactions in policy and the programmes being implemented have to be stressed. In Estonia, this can be seen through the importance given to it in the Lifelong Learning Strategy 2020, which includes an entire programme for enhancing the concordance between education and labour market-relevant competencies. The Ministry of Economic Affairs, which coordinates the area of ICT, has in fact directed $€ 8.5$ million (in the years 2014-2020) to support organisations and enterprises in increasing the digital literacy' and ICT skills of the working population (Estonian Minister of Economic Affairs, 2015). In Austria, this is evident from the fact that the country now holds a lively discussion about how to provide adult learners with ICT skills and that it develops training programmes. For example, 'EBMOOC' (Adult Education Massive Open Online Course) is a six-week online school offered by CONEDU, an Austrian service provider for adult education (Aschemann, 2017, p. 91). The curriculum, which includes a digital tools programme for adult educators, contains different tasks in adult education training and management; participants receive a certificate and ECTS points.

Estonia and Austria also differ markedly in their response to PIAAC due to the differing conditions in the countries. Austria's performance in literacy, unlike Estonia's, was disappointing. Just 8.4 per cent of Austrian adults reached 'good' or 'satisfying' results in literacy, which means that a lot of people have difficulties in understanding texts of any kind; they only understand information if it is explicit and if the grammar is simple. These people with lower literacy skills are massively disadvantaged at the workplace and in everyday life (Gruber \& Lenz, 2016, p. 88). 
A call for action may involve an extended and free offer of adult literacy classes through the 'Adult Education Initiative', a nationwide programme, financed by the state and the regions (Schmid et al., 2014,p. 116), reflecting a modernisation and state control strategy (Lima \& Guimarães ,2011).

Estonia faces problems with ICT skills and widespread insecurity in dealing with computers. This is seen as a serious barrier to participation in society. For this reason, the importance of ICT skills has been given even more importance, and the goals of teacher education and training have been modified to make certain that all teachers have the necessary competences to educate the younger cohorts and to be able to work in the changing economy (Estonian Government, 2014). Unlike in Austria, little attention has been paid to literacy and numeracy, because mass immigration has not (yet) affected Estonia, hence there are few illiterate people.

Another aspect in which the countries differ is the number of follow-up studies. Especially in Austria, researchers have reacted with further studies to analyse in depth the weak results in literacy and to provide some advice for national adult education policies. Lassnigg, Steiner, and Vogtenhuber (2014) identified a large group of adults who have to be provided with basic literacy offers through the 'Adult Education Initiative' (p. 95). The study revealed a strong uneven distribution of this group according to demographic characteristics. While gender was no strong factor for belonging to this group, age was significant: Among 6-24-yearolds, 12.9 per cent belonged this group, which is relatively low compared to 27.6 per cent among 55-64-year-olds (p. 94). These results can be seen as a first marker to improve the national situation in terms of teaching literacy skills. In Estonia, there have been no large-scale follow-up studies so far, but Estonia has made it a goal to keep participating in the PIAAC studies.

Another notable difference between the countries was in the critical response of the scientific community. In Austria, the scientific critique gained a lot of attention and included discussions on the lack of methodological validity and the difficulties that come with researching skills and competencies of national labour markets in standardised international surveys (Knett, 2014). Estonian researchers were more reserved in this regard, and there was no public critique of the methodology, although researchers working with the data were aware of its limitations (see e.g. Anspal et al., 2014; Halapuu \& Valk, 2013).

\section{Final remarks: Results and reflections on the comparison}

In recent years, international organisations have become prominent actors in lifelong learning and training policy. It is believed that transnational adult education might improve the competitiveness of national economies with regard to the 
wealth of nations. Therefore, adult education now matters for decision-making in international settings (Grek, 2010), as international organisations are considered to be 'key agencies for change' (Evans, 2014). These matters are dealt with by a wide set of tools, including processes of 'soft law' performed by the OECD (Marcussen, 2004; Bieber \& Martens, 2011) and benchmarks set by the European Union (i.e. the lifelong learning participation rate). Owing to these reasons, adult education policies are currently being developed on a transnational scale, following mainly human resources management guidelines. Increasing globalisation phenomena and competitive economic environments are forcing national governments to seek a competitive advantage, which is defined through evaluating the performance of national education and training systems according to international standards.

As Rubenson (2015) points out, PIAAC is strongly related to this trend, as many of the survey questions concern activities such as learning undertaken for jobrelated reasons. The PIAAC guidelines fall in between a human resources management model and the modernisation and state control model. The guidelines claim the need to adjust workers to the job, to promote adaptability and productivity growth. As a result, education and training in all forms gain market value, since adult learning can be translated into investments with an economic return. Complementarily, following OECD aims and according to several authors, even without having a direct impact, PIAAC results influence policy-making, because they stress the need to develop the education and training system for economic modernisation and the production of skilled labour (Jones, 2007; Grek, 2009). The influence of PIAAC in national (Austrian and Estonian) adult education policies was made clear in this article. Our research has shown that PIAAC survey results have had an impact on national policy discussions, on official documents, and/ or on research in the field of adult education. This influence was similarly visible in both Austria and Estonia.

On a national and a transnational level, PIAAC encourages participating countries to work on standardised areas and goals of adult education. Taking international best practices into account is an important part of improving future policies on both levels. But we have also seen that harmonisation through standardisation does not necessarily mean strong convergence - as different national and local situations imply the need for differing approaches.

In Austria and Estonia, current adult education policies emphasise aims that follow human resources management guidelines, combined with modernisation and state control ones (Lima \& Guimarães, 2011). These aims have the purpose of making the two countries' economies competitive on a transnational scale. As stated by Rubenson, with the aim of 'promoting the relationship between lifelong 
learning and economic and social prosperity as a production function' (Rubenson, 2015), PIAAC had a relevant influence on the definition of national policy programmes. This influence was and is directed at improving adults' knowledge by upskilling them for current and future labour market requirements.

Questions regarding the process of including international evaluations in national policy making and public discussions remain pertinent. Although we identified influences that were written down, we did not focus on behind-the-scenes processes. Another question worth exploring is how and/or how much the PIAAC influences real changes in (adult) education practice. In addition to this, another question concerns the validity and the comparison of the results: The development of the survey methodology remains an open issue.

\section{References}

Anspal, Sten / Järve, Janno / Jürgenson, Anne / Masso, Märt / Seppo, Indrek: Oskuste kasulikkus tööturul. PIAAC uuringu temaatiline aruanne $\mathrm{nr}$ 1. Estonian Ministry of Education and Research: Tallin 2014, retrieved 20.04.2017 from https://hm.ee/sites/default/files/jarelevalve/oskuste_kasulikkus.pdf.

Aschemann, Birgit: "Die digitale Bereitschaft der Erwachsenenbildung. Der EBmooc für ErwachsenenbildnerInnen". Magazin erwachsenenbildung.at 30, 2017, pp. 85-94, retrieved 14.03.2017 from http://erwachsenenbildung.at/ magazin/17-30/meb17-30.pdf.

Bieber, Tonia / Martens, Kerstin: "The OECD PISA study as a soft power in education? Lessons from Switzerland and the US". European Journal of Education 46(1), 2011, pp. 101-116.

Evans, Jeff: "New PIAAC results: Care is needed in reading reports of international surveys". Adults Learning Mathematics: An International Journal 9(1), 2014, pp. 37-52.

Field, John: "Lifelong education". International Journal of Lifelong Learning 20, 2001, pp. 3-15.

Field, John: Lifelong Learning and the New Educational Order. Trentham Books: Stoke on Trent 2006.

Grek, Sotiria: "Governing by numbers. The PISA 'effect' in Europe". Journal of Education Policy 24(1) 2009, pp. 23-37, retrieved 9.6.2017 from http://www. research.ed.ac.uk/portal/files/14608705/Governing_by_Numbers.pdf.

Grek, Sotiria: "International organisations and the shared construction of policy 'problems'. Problematisation and change in education governance in Europe". European Educational Research Journal 9(3), 2010, pp. 396-406, retrieved 9.6.2017 from http://journals.sagepub.com/doi/pdf/10.2304/eerj.2010.9.3.396. 
Gruber, Elke / Lenz, Werner: Erwachsenen- und Weiterbildung Österreich. Bertelsmann: Bielefeld 2016.

Halapuu, Viivika / Valk, Aune: Täiskasvanute oskused Eestis ja maailmas. PIAAC uuringu esmased tulemused. Estonian Ministry of Education and Research: Tallin 2013, retrieved 20.04.2017 from https://www.hm.ee/sites/default/files/ piaac_esmased_tulemused.pdf.

Jakobi, Anja: "International organisations and policy diffusion. The global norm of lifelong learning". Journal of International Relations and Development 15, 2012, pp. 31-64.

Jones, Phillip W.: "Education and world order". Comparative Education 43(3), 2007, pp. 325-337.

Krippendorff, Klaus: “Content Analysis". In: Barnouw, Erik / Gerbner, George / Schramm, Wilbur / Worth, Tobia L ./ Gross Larry (eds.): International Encyclopedia of Communication, Vol. 1. Oxford University Press: New York 1989, pp. 403-407, retrieved 3.07.2017 from http://repository.upenn.edu/asc_ papers/226.

Knett, Hannes: "Does the PIAAC really matter? Schlussfolgerungen aus Sicht der Wirtschaft und der Unternehmen". Magazin erwachsenenbildung.at 23, 2014, pp. 103-112, retrieved 14.03.2017 from http://erwachsenenbildung.at/magazin/ 14-23/meb14-23.pdf.

Lassnigg, Lorenz / Steiner, Mario / Vogtenhuber, Stefan: "Nutzung von PIAAC für Zielwerte in der Erwachsenenbildungspolitik. Neue Schätzungen über die Zielgruppengröße der Initiative Erwachsenenbildung". Magazin erwachsenenbildung.at 23, 2014, pp. 90-102, retrieved 17.03.2017 from http://erwachsenen bildung.at/magazin/14-23/meb14-23.pdf.

Lawn, Martin / Grek, Sotiria: Europeanizing Education: Governing a New Policy Space. Symposium Books: Providence 2012.

Lee, Moosung / Friedrich, Tom: "Continuously reaffirmed, subtly accommodated, obviously missing and fallaciously critiqued. Ideologies in UNESCO's lifelong learning policy". International Journal of Lifelong Learning 30(2), 2011, pp. 151169, retrieved 9.6.2017 from https://www.eduhk.hk/apclc/dowloadables/Public ations/2011/Continuously\%20reaffirmed,\%20subtly\%20accommodated,\%20 obviously\%20missing\%20and\%20fallaciously\%20critiqued\%20Ideologies $\% 20$ in\%20UNESCO\%27s\%20lifelong\%20learning\%20policy.pdf.

Lima, Licinio C. / Guimarães, Paula: European Strategies in Lifelong Learning. A Critical Introduction. Budrich: Opladen 2011.

Marcussen, Martin: “OECD Governance Through Soft Law”. In: Mörth, Ulrika (ed.): Soft Law in Governance and Regulation. An Interdisciplinary Analysis. Edward Elgar: Northampton 2004, pp. 103-126. 
Ozga, Jenny / Lingard, Robert: "Globalisation, Education Policy and Politics". In: Lingard, Bob / Ozga, Jenny (eds.): The Routledge Falmer Reader in Education Policy and Politics. Routledge: London 2007, pp. 65-82.

Reischmann, Jost: “Comparative Adult Education: Arguments, Typology, Difficulties". In: Reischmann, Jost / Bron Jr, Michal (eds.): Comparative Adult Education 2008. Examples and Experiences. Peter Lang: Frankfurt am Main et al. 2008, pp. 19-32.

Reischmann, Jost / Bron Jr, Michal: "Introduction". In: Reischmann, Jost / Bron Jr, Michal (eds.): Comparative adult education 2008. Examples and experiences. Peter Lang: Frankfurt am Main at al. 2008, pp. 9-16.

Rubenson, Kjell: "Framing the Adult Learning and Education Policy Discourse. The Role of the Organisation for Economic Co-operation and Development". In: Milana, Marcella / Nesbit, Tom (eds.): Global Perspectives on Adult Education and Learning Policy. Palgrave Macmillan: London 2015, pp. 179-193.

Saar, Ellu / Unt, Marge / Lindemann, Kristina / Reiska, Epp / Tamm, Auni: Oskused ja elukestev õpe: kellelt ja mida on Eestl oskuste parandamiseks õppida? PIAAC uuringu temaatline aruanne $n r 2$. Estonian Ministry for Education and Research: Tartu 2014.

Schmid, Gabriele / Tölle, Michael / Steinklammer, Elisabeth / Lichtblau, Pia: "Politische Folgerungen zu den PIAAC-Ergebnissen". Magazin erwachsenenbildung.at 23, 2014, pp. 113-122, retrieved 23.04.2017 from http://erwachsenen bildung.at/magazin/14-23/meb14-23.pdf.

Titelbach, Robert: "Umbauten auf einem Schiff auf hoher See. Ein Aufruf zur Diskussion methodischer Innovationen im Rahmen von PIAAC". Magazin erwachsenenbildung.at 23, 2014, pp. 41-51, retrieved 23.04.2017 from http:// erwachsenenbildung.at/magazin/14-23/meb14-23.pdf.

UNESCO: Global Report on Adult Learning and Education. UNESCO Institute of Lifelong Learning: Hamburg 2009.

Valk, Aune: Õpetajate oskused PIAAC andmete baasil. Estonian Ministry of Education and Research: Tallin 10.12.2013, retrieved from https://www.hm.ee/sites/ default/files/6petajate_oskused_piaac.pdf.

\section{Other documents cited}

Bundesministerium für Bildung: "Bildungsministerin Schmied: 'PIAAC zeigt: Bildungsreform entschlossen fortsetzen"' Bundesministerium für Bildung: Wien, 8.10.2013, retrieved 25.04.2017 from https://www.bmb.gv.at/minister ium/vp/2013/20131008.html.

Department of Education and Science: Learning for Life: Paper on Adult Education. Stationery Office: Dublin 2000. 
Estonian Government: The Estonian Lifelong Learning Strategy 2020. Estonian Government: Tallinn 13.02.2014, retrieved 12.01.2017 from https://www. $\mathrm{hm}$. ee/en/estonian-lifelong-learning-strategy-2020.

Estonian Minister of Education and Research: Adult Skills. Their Use and Usefulness in Estonia, Summaries of Thematic Reports on the PIAAC Study. Thematic Reports on the PIAAC. Estonian Government: Tallinn 2015, retrieved 20.04.2017 from https://www.hm.ee/sites/default/files/inglise_sisu_veebi_14okt.pdf.

Estonian Minister for Education and Research: Tööturu ja õppe tihedama seostamise programm 2016-2019. Estonian Government: Tallinn 2016a, retrieved 12.01.2017 from https://www.hm.ee/sites/default/files/lisa_3_tooturu_ja_ oppe_tihedama_seostamise_programm_2016-2019.pdf.

Estonian Minister for Education and Research: Täiskasvanuhariduse programm 2016-2019. Estonian Government: Tallinn 2016b, retrieved 12.01.2017 from https://www.hm.ee/sites/default/files/lisa_9_taiskasvanuhariduse_prog ramm_2016-2019.pdf.

Estonian Minister of Economic Affairs: Ministri käskkiri 07.01.15 nr 15-0004. Toetuse andmise tingimused digitaalse kirjaoskuse arendamise toetamiseks. Estonian Government: Tallinn, 07.01.2015, retrieved 20.04.2017 from https:// $\mathrm{mkm}$.ee/sites/default/files/diko_kaskkiri_06.01.15.pdf.

Estonian Minister of Education and Research (23.03.2016): Ministri käskkiri 23.03.2016 $n r$ 1.1-2/16/75. Estonian Government: Tallinn 23.03.2016, retrieved 20.04.2017 from https://hm.ee/sites/default/files/ministri_kaskkiri _23.03.2016_nr_1.1-2_6_75.pdf.

Eurostat: Lifelong Learning Statistics. Eurostat: Luxembourg 2017, retrieved 23.04.2017 from http://ec.europa.eu/eurostat/statistics-explained/index.php/ Lifelong_learning_statistics.

OECD: Better Policies for Better Lives. OECD: Paris 2011, retrieved 26.04.2017 from https://www.oecd.org/about/47747755.pdf.

OECD: Education GPS, retrieved 20.04.2017 from http://gpseducation.oecd.org

Postimees: "Postimees teeb ülekande rahvusvahelise täiskasvanute oskuste uuringu konverentsilt.” Postimees Online 10.6.2015, retrieved 20.04.2017 from http:// arvamus.postimees.ee/3220847/postimees-teeb-ulekande-rahvusvahelisetaiskasvanute-oskuste-uuringu-konverentsilt.

Statistik Austria: Schlüsselkompetenzen von Erwachsenen. Erste Ergebnisse der PIAAC-Erhebung 2011/12. Statistik Austria: Wien 2013. 
Regina Egetenmeyer and Monica Fedeli - 978-3-631-73704-0

Downloaded from PubFactory at 01/11/2019 10:08:46AM

via free access 


\title{
Lisa Breitschwerdt \& Vicheth Sen
}

\section{Implementing National Qualifications Frameworks: Difficulties in Cambodia and Germany}

\begin{abstract}
Drawing on Young's (2009) framework on difficulties during the implementation of qualifications frameworks, this contribution compares the difficulties of implementation in Cambodia and Germany. The main problem in Germany is translating the framework into practice at the professional level, whereas in Cambodia, implementation is being hampered by fragmentation and competition among the involved ministries and institutions.
\end{abstract}

\section{Introduction}

Qualifications frameworks have been increasingly adopted by countries throughout the world since the 1980s, rendering it a global phenomenon (Young, 2003). Countries such as the United Kingdom, New Zealand, Australia and South Africa are among the pioneers in designing qualifications frameworks. Largely driven by 'powerful political and economic forces' and underpinned at the core by the 'debates about the nature and purposes of education and training' (Young, 2003, p. 236), this popularity has intensified in the past several years, with more than 100 countries now considering, developing, or implementing qualifications frameworks (Allais, 2011; UNESCO, 2015).

State governments are interested in having their own qualifications framework because they see them as a tool for making educational institutions 'more accountable' and for comparing their education system to those of other countries (Young, 2003, p. 228). Qualifications frameworks have been considered a useful policy instrument to improve the relationships between labour markets and education and training institutions (Allais, 2011). They also provide a mechanism that enables governments to recognise prior learning and to 'validate non-formal and informal learning' (Bohlinger, 2012, p. 282). They encourage lifelong learning by functioning as a mechanism to integrate initial and ongoing education and training, higher education, and non-formal and informal learning into a unified system (ibid.). In a nutshell, qualifications frameworks offer several benefits: 'the modernisation of education and training systems and programmes, the promotion 
of labour market mobility and transnational cooperation and the promotion of all forms of lifelong learning' (Bohlinger, 2012, p. 283).

Although there is a common idea of perspectives and benefits, the realisation of a national qualifications framework cannot be based on a uniform concept. The specificity of every country's circumstances and parameters plays an important role in this. The authors of this paper expect that these country-specific contextual disparities lead to different problems and challenges when it comes to the question of implementing qualifications frameworks. The paper aims to answer the following question: What difficulties do Cambodia and Germany face during the implementation of their qualifications frameworks? What are similarities and differences? The countries were selected because of their different geographical location and societal structures. This allows for determining whether there are similar difficulties despite different contexts. Both countries face linkage needs to regional qualifications frameworks (EU and ASEAN), and both are currently in the process of its implementation.

Therefore, the paper first outlines the main characteristics of the national qualifications frameworks of Cambodia and Germany and identifies comparative categories concerning difficulties in implementing qualifications frameworks. Afterwards, difficulties in implementing qualifications frameworks in both countries, and the commonalities and differences between the two cases will be analysed. Finally, the paper summarises the different difficulties in implementing qualifications frameworks in both contexts and provides an outlook on further research questions.

\section{Characteristics of national qualifications frameworks in Cambodia and Germany}

\section{Cambodian Qualifications Framework}

The Cambodian Qualifications Framework was born out of a policy process that aims to promote a highly competitive and economically integrated Association of Southeast Asian Nations (ASEAN). In recognition of the varying developmental states and levels of qualifications frameworks of its member states, ASEAN has its own policies and processes for the mutual recognition of qualifications granted by its member states and other associated member states. The process towards the ASEAN Economic Community in 2015 was accompanied by various policy instruments. The ASEAN Qualifications Reference Framework, for instance, was developed to 'enable comparisons of qualifications across ASEAN Member States', 
focusing on education and training and lifelong learning (Association of Southeast Asian Nations, 2015, p. 4).

Within this regional context, the Cambodian Qualifications Framework aims to ensure that qualifications within Cambodia and in the region can be compared in terms of equivalence (Royal Government of Cambodia, 2012). The Royal Government of Cambodia considers the Cambodian Qualifications Framework a crucial instrument for the country to standardise its system of education and training, so that its citizens are able to attain qualifications comparable in quality to the regional standard (RGC, 2012). It aims to provide recognition of prior learning and flexible pathways to academic and technical and vocational education and training; promote lifelong learning; encourage the provision of quality education and training relevant to the labour market needs; promote national and international recognition of qualifications attained in Cambodia; and facilitate the regional flow of skilled labour (RGC, 2012).

There are four core elements: levels of qualifications, credit hours, learning outcomes, and study pathways (RGC, 2012, pp. 2-7). There are eight levels of qualifications for technical and vocational education and training; the first four levels lead to a vocational certificate, and technical and vocational certificates 1,2, and 3 , all of which are equivalent to the secondary education standard. For higher education, there are four levels of qualifications. For the Cambodian Qualifications Framework, 15 hours for 1 credit is a measure of the amount of instruction. For teaching activities that involve laboratory work or workshops, 1 credit equals 30 hours. And for fieldwork or internship training activities, 1 credit equals 45 hours.

Learning outcomes are organised into two sets of competence: basic and core competence, both divided into five major areas: (i) knowledge, (ii) cognitive skills, (iii) psychomotor skills, (iv) interpersonal skills and responsibility, and (v) communication, information technology and numerical skills. The five areas of learning outcomes apply to all programmes in technical and vocational education and training. For higher education, only four areas are applicable to all programmes; a fifth area, psychomotor skills, applies to only some programmes. By means of regulations on the accumulation and transfer of credits and the accreditation of prior learning acquired through formal, non-formal, and informal learning, the Cambodian Qualifications Framework provides study pathways that enable individuals to move between technical and vocational education and training and higher education. As of this time of writing, the Cambodian Qualifications Framework has yet to be implemented. 


\section{German Qualifications Framework for Lifelong Learning}

In Germany, the development and implementation of a qualifications framework is strongly guided by the European processes and goals, beginning with the Bologna Declaration of 1999 and the Lisbon Strategy of 2000. The main aim of these strategies was to make the European Union a competitive and dynamic economic zone, based on knowledge and including education and training for living and working in this society (European Parliament, 2000, no. 26). The idea was to define the necessary and important areas of knowledge and skills for each educational level to have a quick overview of the workforce and make educational levels comparable across Europe. This was set within the development of the European Qualifications Framework in 2008.

In Germany, two coordination bodies were established in 2007 to generate the German Qualifications Framework. The 'Federal/State Coordination Group' (Bund-Länder-Koordinierungsstelle) is composed of government bodies (e.g. ministries); the 'German Qualifications Framework Working Group' (Arbeitskreis Deutscher Qualifikationsrahmen, AK DQR) consists of representatives of all relevant areas of society (e.g. education, economic organisations, scientists, and practitioners). The aim of developing a National Qualifications Framework for Germany was to link the German qualification levels to the European levels and take account of the exceptions in the German education system.

According to the recommendation of the EU, Germany developed its framework and linked it to the European Qualifications Framework by the end of 2010, assigned the qualifications, and documented national qualifications and European qualifications levels on national certificates by the end of 2012 (Eckelt, 2016, p. 101). The final framework was officially implemented on 1 May 2013, and since 2014 the process of assigning formal qualifications to the levels of the German Qualifications Framework has been underway. For formal qualifications, an obligatory procedure assignment was introduced, whereas the assignment of non-formal and informal competencies has not taken place yet, but there is a suggestion about the criteria and procedures.

Similar to the European Qualifications Framework, the German Qualifications Framework is structured in eight consecutive levels (starting with level 1 on the bottom) describing the necessary learning outcomes. Levels 5 to 8 are compatible with the German Higher Education Qualifications Framework. Unlike in the European Qualifications Framework, the described outcomes are segmented into four pillars of competence areas, covering 'professional competence', subdivided into 'knowledge' and 'skills', and 'personal competence', subdivided into 'social competence' and 'autonomy' (Arbeitskreis Deutscher Qualifikationsrahmen, 
2011, p. 5). Methodological competence does not appear in the framework as it is considered a part of all other competencies.

In the German Qualifications Framework, the concept of competence encompasses all learning outcomes. With this focus on competencies, especially personal competencies, the framework tries to refer to the characteristics of the German education system, which is particularly based on the term Bildung and the related idea of the possibility of enlightening and developing each person through education. This understanding also becomes visible in the definition of competence in the German Qualifications Framework as the ability and willingness of every individual to use knowledge and skills, and also personal, social and methodological abilities and to act deliberately, individually and socially accountably' (AK DQR, 2011, p. 4).

\section{Categories for comparison}

There are different contextual circumstances for the implementation of National Qualifications Frameworks, which refer to the characteristics of the nation. Nevertheless, it is not unusual for problems to occur when implementing big structural reform projects like a National Qualifications Framework (Young, 2009). In this paper, Young's (2009) comparative categories are used for the discussion of difficulties in implementing national qualifications frameworks. In his overview of implementation problems, Young (2009) distinguishes between three areas or levels of problems: political, administrative, and technical/professional.

By political difficulties, firstly, Young (2009) refers to the fact that the responsibility for developing and implementing a national qualifications framework involves more than one government department (e.g. ministries or departments of education, labour, and trade). This presents major difficulties for a smooth process of implementing a national qualifications framework, simply because each department has its own agenda. Secondly, administrative difficulties refer to problems that accompany the development of new instruments of structure and regulation (e.g. quality assurance, standard setting, and assessment) in the process of national qualifications framework implementation. The main difficulties at this level concern the uncertainty of responsibilities that these new agencies are to perform and the difficulties for them to recruit staff members with appropriate skills and knowledge to perform the tasks in the implementation process (Young, 2009). Finally, Young (2009) understands technical or professional difficulties as problems concerning the concrete realisation of new activities (e.g. assessment, new language standards, and defined criteria) connected with the focus on learning outcomes. These difficulties arise from the fact that the descriptions 
for different levels of learning outcomes and for different qualifications are often jargon-laden and prove to be challenging for non-specialists or people outside of a particular sector to understand and relate to. Also connected to this is the question of what knowledge is and how it is acquired and assessed, which presents another layer of difficulties in implementing a national qualifications framework. Besides offering this classification of difficulties, Young also points out that one overall problem of the system of national qualifications frameworks is that the people who are working in the system increasingly become disconnected from it (Young, 2009, pp. 2917-2918).

\section{Comparison of the difficulties in implementing national qualifications frameworks}

The goals and objectives of implementing a national qualifications framework are quite similar in Cambodia and Germany: to simplify and support the transparency of qualifications and make them comparable internationally. It should improve and strengthen the overall perspective of the labour market. Nevertheless, there are minor differences, owing to the countries' different socio-economic status. In Cambodia, the focus lies on the provision of high-quality education, the connectivity to international standards, and the improvement of access to education and training. As a country emerging from prolonged civil armed conflict, Cambodia's current state of educational development is still in its initial stage and is confronted with many issues that are not present in countries such as Germany. In contrast, Germany is more focused on topics of improving overall permeability in its education and training system and strengthening the orientation on learning outcomes, including the recognition of non-formal and informal acquired qualifications.

These similarities and differences are also shown in the structure of the national qualifications framework outlined in Table 1. Both qualifications frameworks contain eight levels and are divided into the areas of general, higher, and vocational education, with Cambodia explicitly outlining technical training in their vocational education area. Both countries place the bachelor's, master's, and doctoral degree at levels 6,7, and 8. In Germany, there is no qualification at level 5 (transition between general and higher education), because the general higher education entrance qualification is assigned to level 4. In Cambodia, the higher education system is divided into academic (or higher education) and technical and vocational education and training. Both streams offer the highest degree programme at the doctoral level. 


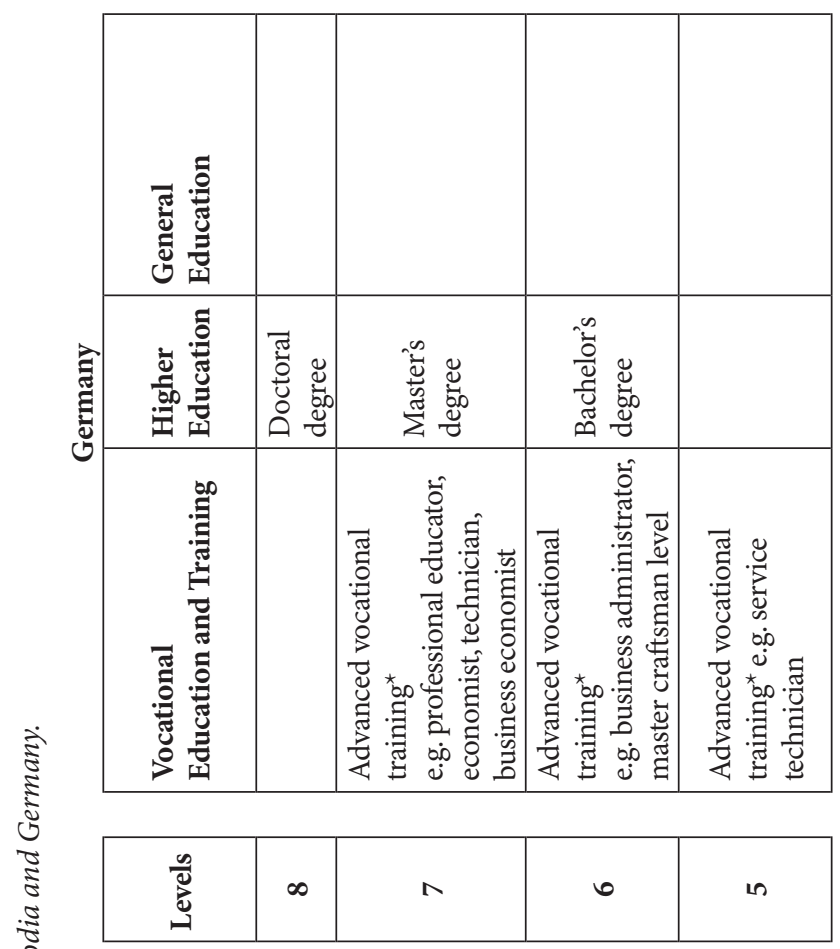

ई

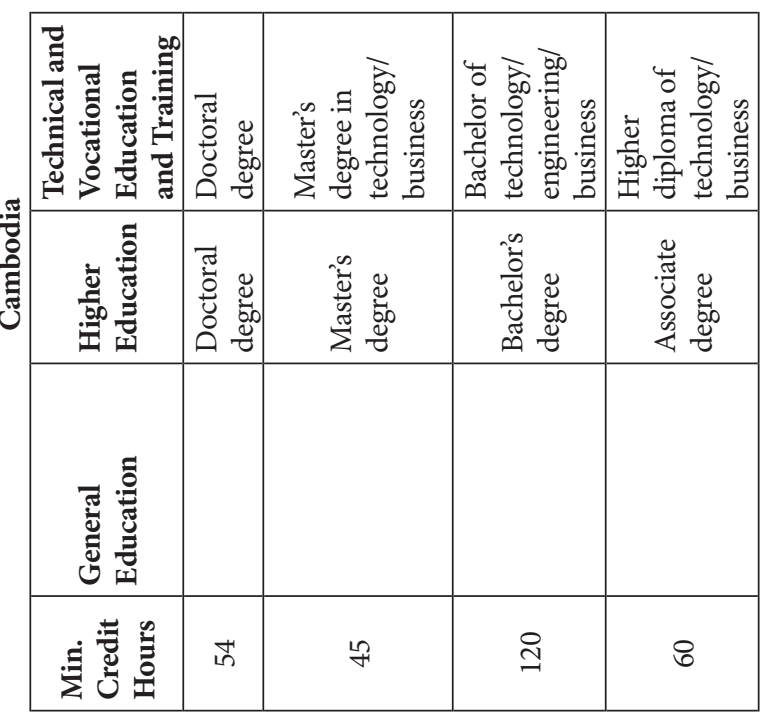

Regina Egetenmeyer and Monica Fedeli - 978-3-631-73704-0 Downloaded from PubFactory at 01/11/2019 10:08:46AM 

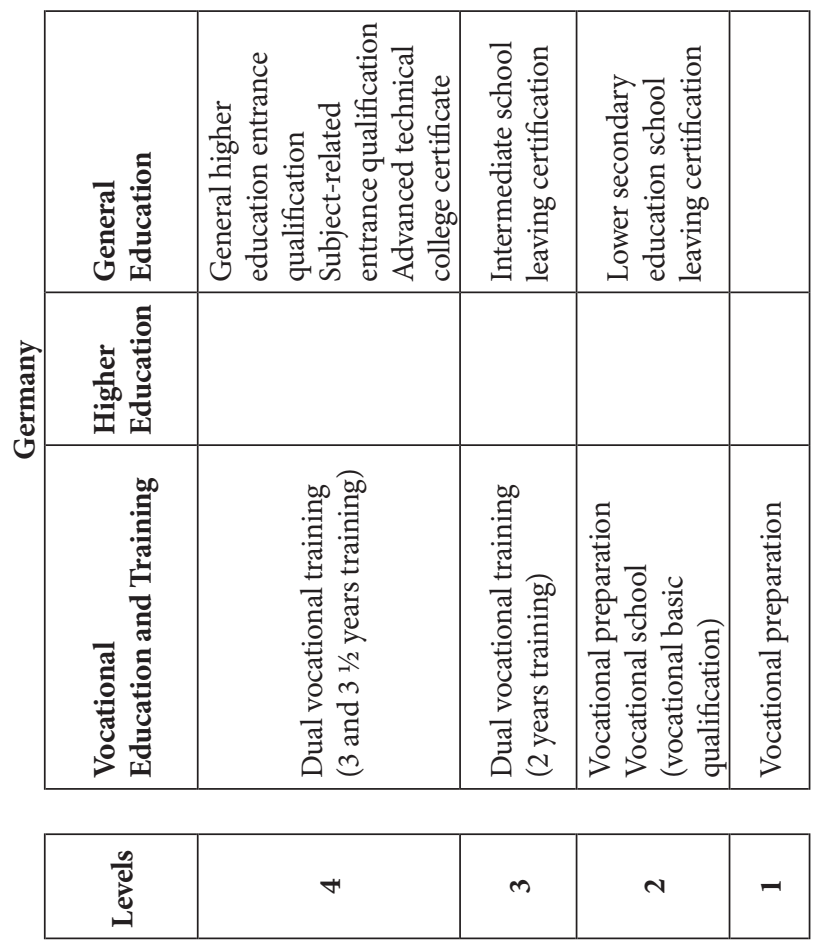

के

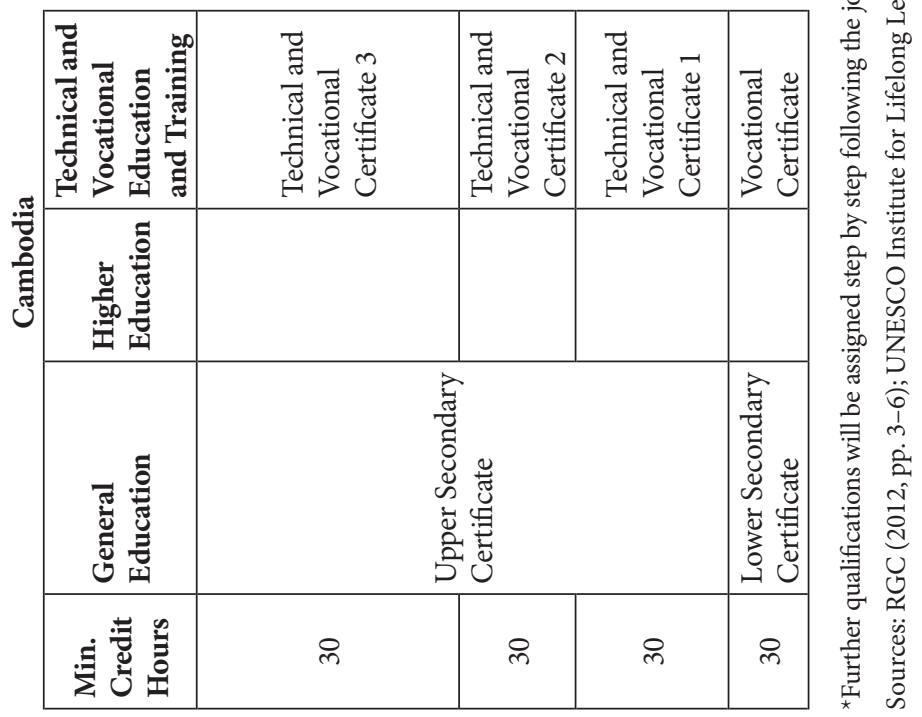

Regina Egetenmeyer and Monica Fedeli - 978-3-631-73704-0

Downloaded from PubFactory at 01/11/2019 10:08:46AM 
Although the levels are the same, there are some differences in the definition of categories of learning outcomes. Both the categories of knowledge and skills and the aspects of personal factors are important. But while the Cambodian framework goes deeper into defining the skills needed in a globalised world, such as information technology skills, Germany is more general and focuses on the translation of skills into practice by using the concept of competencies.

As expected in the beginning, a detailed look at the national qualifications frameworks shows some differences. That is why it is not surprising that there are also some major differences when it comes to the question of implementation difficulties. Based on Young's (2009) categories of difficulties in implementing national qualifications frameworks, the following commonalities and differences can be outlined.

\section{Political difficulties}

\section{Cambodia}

In the current context of Cambodia's higher education system, the multiplicity of authorities governing higher education creates major political difficulties that potentially challenge the implementation of the Cambodian Qualifications Framework. Although numerous reform efforts have been made to improve the governance of the system, it continues to be fundamentally fragmented (Chet, 2006; Dy, 2015; Sen, 2013, forthcoming; Sen \& Ros, 2013; Un \& Sok, 2014). The higher education institutions are under the supervision of a wide range of parent ministries/institutions. According to the 2016 Education Congress Report (MoEYS, 2016), there were 118 higher education institutions located in 19 provinces and the capital; 46 of these were public higher education institutions and 72 private higher education institutions. These higher education institutions were supervised by 15 different parent ministries/institutions. In particular, these supervisory ministries/institutions very often have competing interests and do not necessarily come to common terms, especially in the areas of policies and regulations (Sen, forthcoming). For example, there exists a high degree of competition and a lack of cooperation between two of the main ministries responsible for education and training in Cambodia; namely, the Ministry of Education, Youth, and Sport (MoEYS) and the Ministry of Labour and Vocational Training (MoLVT) (United Nations Development Program, 2011).

Moreover, although the MoEYS is mandated to formulate policies and plans to evaluate the education sector and to improve the quality of education (RGC, 2009), it has the same legal status and jurisdiction as the other supervising ministries/institutions; that is why its authority at inter-ministerial meetings with 
other ministries to discuss cross-sectoral issues related to education and training is mainly limited to non-policy discussions (Sen \& Ros, 2013). An effort to address this power competition among parent ministries/institutions through the establishment of a national coordination body (the Supreme National Council of Education) proves to be a failed attempt. Although stipulated to be established in the 2007 Education Law (RGC, 2007), a decade later the Supreme National Council of Education has not yet materialized.

Although the Cambodian Qualifications Framework is yet to be implemented, this contextual landscape in relation to the political environment in Cambodia's current education system presents fundamental difficulties for a successful implementation of the framework. Any implementation of a national qualifications framework will definitely involve inter-ministerial or inter-departmental coordination and collaboration. The current governance structure of Cambodia's education system does not lay a stable foundation for an effective implementation of the country's national qualifications framework.

\section{Germany}

In Germany, the idea of developing a qualifications framework was supported strongly by federal policy. As a consequence, many difficulties in its implementation lay, and still lie, in the administrative process of developing the German Qualifications Framework. The decision to include a huge variety of stakeholders with different interests in the implementation process necessitated many consensusbuilding discussion sessions between them.

As a consequence, when the German Qualifications Framework was enacted on 22 March 2011, a rough concept of the competence levels and categories was fixed, but the qualifications of the German education system had not yet been assigned to the eight levels. In addition, it was unclear at this time how to include non-formally and informally acquired competencies in the qualifications framework, which was one of the goals. Overall, several compromises were made to reconcile the interests of different actors in the process of enacting the German Qualifications Framework. Sometimes these compromises were hard to understand. For example, the former representative of the Ministry of Education and Research demanded that the competence category 'self-competence' be changed to 'autonomy', although the task force had worked with the first term for about two years. To make the concept easier to understand for citizens, the term was changed and did no longer conform to the underlying concept of an overall 'action competence' (Odenwald, 2012, p. 202). 
Consequently, even though there was the shared political intention to implement a German Qualifications Framework, there were, and still are, many points of discussion, arising not least from the inclusion of so many actors in the process. Especially after the official enactment of the German Qualifications Framework in 2013, further problems and discussions arose concerning its realisation.

\section{Comparison}

Cambodia and Germany face political difficulties at different levels. In both cases, the main difficulty is the clash of competing interests that have to be negotiated. While in Cambodia the final implementation and practical realisation of the Cambodian Qualifications Framework is still prevented by the issues of system fragmentation and communication between the involved ministries and institutions, in Germany, where the German Qualifications Framework has been successfully implemented, this problem arises again in the ongoing development process, preventing the finalisation of the Qualifications Framework. In Cambodia, it is more about the governance structure of the education system in the first step of implementation; in Germany, there is the challenge of including the educational needs of the different parts of a highly divisive education system in the second step of implementation.

\section{Administrative difficulties}

\section{Cambodia}

Administrative difficulties in implementing the Cambodian Qualifications Framework are another major challenge rooted in the current quality assurance system. If the implementation of the Cambodian Qualifications Framework were to be undertaken under the same structure and regulation of quality assurance, a wide range of administrative difficulties would be imminent, particularly the capacity of the quality assurance body (Sen, 2016, forthcoming; Sen \& Ros, 2013). Established in 2003, the Accreditation Committee of Cambodia (ACC) plays a central role in accrediting education programmes offered at higher education institutions, both academic and technical and vocational, across the country (RGC, 2003).

However, the ACC has not moved beyond accrediting the foundation-year programmes at most higher education institutions (Dy, 2015; Un \& Sok, 2014; Touch, Mak, \& You, 2013), although it was led by qualified individuals. The question of the quality of higher education in Cambodia remains a major issue (Dy, 2015; International Labour Organization and Asian Development Bank, 2015; MoEYS and the World Bank, 2015; Sen, forthcoming; Un \& Sok, 2014). This issue 
may be attributed to the rapid and uncontrolled expansion of the number of higher education institutions over the past 15 years, which has overwhelmingly exhausted the capacity of the ACC to sufficiently carry out its tasks (Dy, 2015; Sen, forthcoming). In particular, it was and remains challenging to recruit and train assessors with relevant knowledge and expertise (Un \& Sok, 2014). Coupled with these challenges is the shortfall of funding (Dy, 2015; Sen, 2013; Sen \& Ros, 2013).

It remains to be seen how the new instruments of structure and regulation in relation to quality assurance, standards setting, and assessment for the implementation of the Cambodian Qualifications Framework will be developed. However, lessons from the existing quality assurance mechanism have shown that there are numerous challenges in doing this. There is a need to rethink the organisational structure and approaches at the administrative level in the context of Cambodia.

\section{Germany}

Eckelt (2016) states that a lot of the problems in the German process of implementation are grounded in the type of administrative procedure chosen, for example the dominance of vocational training and the precarious position of the field of continuing education (Eckelt, 2016, p. 107). In the years after the German Qualifications Framework came into force, the interest groups discussed a lot about the assignment of formal qualifications and have not even reached a partial agreement now. For example, there is continuing discussion and disagreement about the position of general and vocational education in the framework. The general qualification for university entrance should be assigned to level 5 , whereas the assignment of occupations varies from level 3 to 5 . This means the school leaving examination has a higher value than a vocational training programme, which lasts for three or three and a half years. This was criticised sharply by the trade unions and the economic representatives, resulting in a long gridlock until general school leaving qualifications were finally assigned in March 2017 (Bundesministerium für Bildung und Forschung, 2017). In addition, there were discussions about the formulation of learning outcomes, such as the nature of the scientific problemsolving competence, which was perceived as too vague by the higher education sector as compared to the field of vocational education from the perspective of its representatives (Böllert, 2010, p. 96). Representatives of continuing education in particular currently criticise the previous procedure of assignment, which they say neglects the value of informal education by focussing on formal qualifications first. The idea of a comprehensive understanding of education in which formal, non-formal, and informal education stand side by side equally was so far ignored in this process (ibid, p. 97). 
Next to these problems of assignment and formulation there are difficulties caused by the adoption of foreign models with too little reflection or without creating own models during the implementation process. One example is the establishment of accreditation agencies based on the Anglo-Saxon model, which are responsible for the quality assurance of German study programmes (Immer, 2013, p. 3). Recently, there was a resolution of the Federal Constitutional Court (Bundesverfassungsgericht, 2016) concerning study programs in the state of North Rhine-Westphalia, stating that the process of accreditation conflicts with the right to academic freedom in Germany, as it intervenes directly into the formation and contents of scientific teaching. As a result, legislators have to pass a new law by 31 December 2017 showing that the steps of developing their own structures and rules as part of the fast-paced implementation process must not be neglected by the responsible authorities (ibid., pp. 3-6).

\section{Comparison}

In both cases, the common challenge at this level concerns the uncertainties about the roles and responsibilities of the accreditation agencies. While in Cambodia the existing accreditation agency does not have a good history of having adequate capacity to carry out its tasks, the case of Germany involves the role of accreditation agencies, in particular in the context that these agencies are established based on foreign models without sufficient attention paid to adapting them to the country's own system. Moreover, in Germany, the administrative procedure adopted for the implementation of the German Qualifications Framework creates tension between higher education and vocational education in terms of assigning certifications. In Cambodia, in contrast, this kind of tension between the Ministry of Education, Youth and Sport, and the Ministry of Labour and Vocational Training is present at the political level; however, it is highly likely that it trickles down to the administrative level when the implementation of the Cambodian Qualifications Framework commences.

\section{Technical or professional difficulties}

\section{Cambodia}

The main challenge to implementing the Cambodian Qualifications Framework at the technical or professional level involves the fact that Cambodia's higher education institutions, both academic and technical and vocational, are severely underfunded. In general, Cambodia's higher education institutions are basically teaching-based institutions and support themselves through tuition fees (Ahrens 
\& McNamara, 2013; MoEYS \& World Bank, 2015; Peou, 2015; Sam \& Dahles, 2017). Teaching itself is largely lecture-based and rarely informed by research (MoEYS \& World Bank, 2015). While 80 per cent of the revenue for public higher education institutions is privately funded (Ahrens \& McNamara, 2013), all private higher education institutions do not receive government funding and rely almost totally on tuition fees (Sam \& Dahles, 2017; Sen \& Ros, 2013). Government funding for public higher education institutions is mainly to cover the institutions' basic operational costs (Sen, forthcoming).

The academics at both public and private higher education institutions engage in heavy teaching because there is no funding source for research for them to apply for and engage in research activities (MoEYS \& World Bank, 2015). Within this contextual reality, both public and private higher education institutions find it extremely challenging to respond to the new demands of the Cambodian Qualifications Framework, particularly in relation to developing a new language of standards, units, and levels that defines assessment criteria applicable to the learning outcomes of the Cambodian Qualifications Framework. In this context, where lecturing and marking exams is the predominant aspect of higher education instruction, responding to the kinds of assessment required by different levels of learning outcomes in the new Cambodian Qualifications Framework would prove to be a major challenge for the stakeholders concerned at the higher education institution level.

Added to this series of challenges is the fact that research is virtually nonexistent at Cambodia's higher education institutions. So the question related to different types of learning and knowledge acquisition might not even be considered by the actors involved at this level of implementation. Although this may not be necessarily a challenge to implementing the Cambodian Qualifications Framework, the lack of discussion on this issue among the concerned actors may in fact present a cause of concern over the lack of critical evaluation of the outcomesbased qualifications framework.

\section{Germany}

After enactment, the most challenging step of implementation lies ahead: educational practice. The change of focus from learning contents to learning outcomes requires educators to rethink the practice of teaching and learning. There are no valid statements about the acceptance of the German Qualifications Framework in German educational practice yet.

First surveys and interviews of people involved in the implementation process indicate that the German Qualifications Framework is accepted as an important 
instrument that generates opportunities for the modern and international education system (Neß,2009). There are differences in acceptance between the various areas of education, which are partially justified by the state of assignment of the formal qualifications in the German Qualifications Framework and their relevance to practice. For example, the representatives of school education have reservations because of the continuous assignment of its formal degrees, whereas representatives of vocational education and training are encouraged by the visibility of their field in the far advanced process of assigning degrees (Eckelt, 2016, pp. 364-365). In contrast, estimating the extent to which the German Qualifications Framework is accepted and realised in the field of continuing education, which does not work with formal degrees, is difficult, because a system for the assignment of non-formal and informal competencies does not yet exist. In other cases, providers in the area of continuing education nevertheless are quite interested in using the German Qualifications Framework and started to assign the non-formal qualifications they offer to the different levels (ibid., p. 370). This comparison shows that it is important to include the actors working in the field of education in the further process of implementation (Neß,2010, p. 37). Furthermore, it is necessary to inform and educate the personnel about the new approach of qualifications frameworks and the implementation of new wordings, concepts, and understandings relating to it (Fuchs, 2011, p. 7).

\section{Comparison}

The two countries face similar difficulties in the sense that the introduction of national qualifications frameworks represents a shift from content-based to outcomes-based learning. This will require rethinking in terms of teaching, learning, and assessment. However, a major challenge for Germany concerns the uncertainties regarding a system of assigning competencies in the areas of general, vocational/technical, and continuing education. On the contrary, while Cambodia may face the same challenge, one important challenge for Cambodia is that the country's higher education institutions are teaching-intensive institutions and follow a traditional model of assessment, that is, examinations as the primary assessment of learning. Therefore, implementing the new qualifications framework, which requires a move towards a new model of assessment based on learning outcomes, presents a significant challenge. This is particularly so in the Cambodian context, where higher education institutions are severely underfunded by the government. 


\section{Conclusion}

It could be shown that there are several challenges in implementing qualifications frameworks, and that Germany and Cambodia face different challenges. There may be many reasons for that. First, the differences can be attributed to the large disparities in the education systems. In Germany, there already is a highly standardised education system with standardised training programmes for teachers, compulsory education until ninth grade, and various fixed pathways for students. The implementation of a standardisation instrument like the qualifications framework can build on these qualities of the Germany education system, which now asks for more international transparency. Furthermore, Germany could gather experiences with standardisation processes when it implemented the Bologna Process and the three cycles of the Higher Education Qualifications Framework relating to it. The Cambodian system, in contrast, although characterised by high centralisation in its educational system at the governmental level, has few nationally standardised structures at the local level, which is one result of prolonged civil armed conflict in recent history. This means the country is facing the challenge of implementing a system of standardisation for its whole education system without having any experience in that regard. This becomes visible in the fragmentation of Cambodia's governing authorities. Furthermore, the differences can be caused by the structure of management and participating stakeholder groups. Whereas Germany's educational system is broadly linked to governmental funding and control, Cambodia's is characterised by stronger private engagement in education, with the government's role rather focused on passing and implementing laws and quality regulations.

But in addition to the differences, the two countries, although they are very different from each other, also face similar difficulties. By implementing a national qualifications framework, both countries follow the global trend of more standardisation and transparency in qualifications. Their shared goal is to adjust to global needs, as laid down in the respective regional qualifications frameworks, develop their education and training system, and strengthen the labour market. Given their long history of national education systems, influenced by changing political, societal, and cultural circumstances, both countries now face the challenge to reconcile the call for international transparency with the particular needs of their local education system.

Although the overall goal of transparency is widely accepted and the implementation of different national qualifications frameworks is underway, there also has to be further reflection on the importance and influence of this development in general. Especially when looking at the importance of the historically grown 
national educational systems, it is important to note that some aspects of the global rise of qualifications frameworks also give reasons for concern regarding the direction this development is taking. Noticeably, the general idea of improved transparency, efficiency, and mobility is linked to the ideas of neoliberalism and human resource management, which focuses on the improvement of qualifications first but not necessarily on human beings themselves. In this context, Lauder (2011) warns against the global orientation taking place in the world of business and employment, which is linked to the increasing development of national qualifications frameworks. Based on key trends in the global economy, like the the reducing of costs of knowledge work, which results from the global rise in the supply of graduates, one may raise 'fundamental questions about the nature of knowledge and skills' (Lauder, 2011, p. 213) in general, and national qualifications frameworks in particular. Therefore, a suggestion for further research would be to compare the extent to which qualifications frameworks may be contributing to promoting an individualistic, private consumption of education rather than the dimension of education as a public good.

Implementing a national qualifications framework is not only about fulfilling the requirements of an international context on paper; it also has an important influence on the national educational system and labour market and requires sensitivity from all concerned stakeholders. Therefore, further research about the processes and difficulties in implementing national qualifications frameworks is needed to increase reflection on the reasons for the implementation and the factors and circumstances which accompany the whole implementation process. This means observing and analysing countries like Cambodia and Germany in the further process, especially because they are facing problems on very different levels within the implementation process.

\section{References}

Ahrens, Luise / McNamara, Vincent: "Cambodia: Evolving Quality Issues in Higher Education". In: Symaco, Lorraine P. (ed.): Education in Southeast Asia. Bloomsbury Academic: London 2013, pp. 47-69.

Arbeitskreis Deutscher Qualifikationsrahmen (2011): Deutscher Qualifikationsrahmen für lebenslanges Lernen. Verabschiedet vom Arbeitskreis Deutscher Qualifikationsrahmen (AK DQR) am 22. März 2011, retrieved 11.01.2017 from http://www.dqr.de/media/content/Der_Deutsche_Qualifikationsrahmen_fue_ lebenslanges_Lernen.pdf. 
Allais, Stephanie: "The impact and implementation of national qualifications frameworks. A comparison of 16 countries". Journal of Education and Work 24(3-4), 2011, pp. 233-258.

Association of Southeast Asian Nations: ASEAN Qualifications Reference Framework: Referencing Guidelines. ASEAN: Jakarta October 2015, retrieved 15.01.2017 from http://kkni-kemenristekdikti.org/asset/pdf/2-AQRF_Refere ncing_Guidelines_revised.pdf.

Bohlinger, Sandra: "Qualifications frameworks and learning outcomes. Challenges for Europe's lifelong learning area”. Journal of Education and Work 25(3), 2012, pp. 279-297.

Böllert, Karin: "Entwicklungen und Herausforderungen des Deutschen Qualifikationsrahmens (DQR)". Erziehungswissenschaft. Mitteilungen der Deutschen Gesellschaft für Erziehungswissenschaft (DGfE) 21(41), 2010, pp. 93-100.

Bund-Länder-Koordinierungsstelle: Liste der zugeordneten Qualifikationen. Aktualisierter Stand: 1. August 2016, retrieved 05.05.2017, from https://www. dqr.de/media/content/2016_DQR_Liste\%20der\%20zugeordneten\%20Qualifik ationen_01.08.16.pdf.

Bundesministerium für Bildung und Forschung: German EQF Referencing Report, 2013, retrieved 07.01.2017 from https://ec.europa.eu/ploteus/sites/eac-eqf/ files/German_EQF_Referencing_Report.pdf.

Bundesministerium für Bildung und Forschung et. al.: Vereinbarung zum weiteren Vorgehen beim Deutschen Qualifikationsrahmen (DQR) vom 23.03.2017, retrieved 09.06.2017 from https://www.dqr.de/media/content/Vereinbarung_ BR_KMK_WMK_SP_WO_Stand_23032017.pdf.

Bundesverfassungsgericht: Wesentliche Entscheidungen zur Akkreditierung von Studiengängen muss der Gesetzgeber selbst treffen. Resolution of 17 February 2016. Retrieved 04.05.2017 from https://www.bundesverfassungsgericht.de/ SharedDocs/Pressemitteilungen/DE/2016/bvg16-015.html.

Chet, Chealy: "Cambodia". Higher Education in Southeast Asia. UNESCO Asia: Bangkok 2006, pp. 13-33.

Dy, Samsideth: "Higher Education. Trends, Issues and Policy Options". In: Khieng, Sothy / Madhur, Srinivasa / Chhem, Rethy (eds.): Cambodia Education 2015: Employment and Empowerment. Cambodia Development Resource Institute: Phnom Penh 2015, pp. 31-56.

Eckelt, Marcus: Zur sozialen Praxis der Berufsbildungspolitik. Theoretische Schlüsse aus der Rekonstruktion der Entwicklung des Deutschen Qualifikationsrahmens. Bertelsmann: Bielefeld 2016.

Esser, Friedrich Hubert: "Die Entwicklung des DQR: Bildungspolitische Rückschau und Positionierung". In: Büchter, Karin / Dehnbostel, Peter / Hanf, Georg 
(eds.): Der Deutsche Qualifikationsrahmen (DQR). Ein Konzept zur Erhöhung von Durchlässigkeit und Chancengleichheit im Bildungssystem? Bertelsmann: Bielefeld 2012, pp. 23-32.

European Parliament: Lisbon European Council 23 and 24 March 2000. Presidency Conclusions. Retrieved 14.01.2017, from http://www.europarl.europa.eu/summ its/lis1_en.htm.

Fuchs, Sandra: "Der Deutsche Qualifikationsrahmen. Auswirkungen auf die Erwachsenenbildung und Volkshochschulen. Das Projekt EU-Transfer". Magazin Erwachsenenbildung.at 14, 2011, retrieved 04.05.2017 from http:// erwachsenenbildung.at/magazin/11-14/meb11-14.pdf.

Immer, Daniel: Rechtsprobleme der Akkreditierung von Studiengängen. Universitätsverlag: Göttingen 2013.

International Labour Organization and Asian Development Bank: Cambodia: Addressing the Skills Gap. Employment Diagnostic Study. Asian Development Bank: Manila 2015.

Lauder, Hugh: "Education, economic globalisation and national qualifications frameworks". Journal of Education and Work, 24(3-4), 2011, pp.213-221, retrieved 11.05.2017 from doi: 10.1080/13639080.2011.584683.

Ministry of Education, Youth and Sport / World Bank: Stocktaking Report of Higher Education Quality and Capacity Improvement Project (Development and Innovation Grants). MoEYS: Phnom Penh 2015.

Ministry of Education, Youth and Sport: Education Congress: The Education, Youth and Sport Performance in the Academic Year 2014-2015 and Goals for the Academic Year 2015-2016. MoEYS: Phnom Penh 2016.

Neß, Harry: "Empirische Erhebungen zu den Erwartungen an den Europäischen und Deutschen Qualifikationsrahmen”. In: Dehnbostel, Peter / Neß, Harry / Overwien, Bernd (eds.): Der Deutsche Qualifikationsrahmen (DQR). Positionen, Reflexionen und Optionen. GEW: Frankfurt a.M. 2009, pp. 91-102.

Neß, Harry: "EQR und DQR im Bildungs- und Beschäftigungssystem". REPORT 33(1), 2010, pp. 21-38.

Odenwald, Stephanie: "DQR - quo vadis? Europäisierung der Bildung braucht gewerkschaftliche Einflussnahme". In: Büchter, Karin / Dehnbostel, Peter / Hanf, Georg (eds.): Der Deutsche Qualifikationsrahmen (DQR). Ein Konzept zur Erhöhung von Durchlässigkeit und Chancengleichheit im Bildungssystem? Bertelsmann: Bielefeld 2012, pp. 199-212.

Peou, Chivoin: "On Cambodian higher education and skills mismatch: Young people choosing university majors in a context of risk and uncertainty". Journal of Education and Work, 30(1), 2015, pp. 26-38, retrieved 03.02.2016 from doi $: 10.1080 / 13639080.2015 .1119258$. 
Royal Government of Cambodia: Royal Decree on Accreditation of Higher Education. RGC: Phnom Penh 2003.

Royal Government of Cambodia: Education Law. RGC: Phnom Penh 2007.

Royal Government of Cambodia: Sub-decree on Organization and Functioning of Ministry of Education, Youth and Sport. RGC: Phnom Penh 2009.

Royal Government of Cambodia: Cambodia Qualifications Framework. RGC: Phnom Penh 2012.

Sam, Chanphirun / Dahles, Heidi: "Stakeholder involvement in the higher education sector in Cambodia". Studies in Higher Education, 42(9), 2017, pp. 1764 1784, retrieved 30.08.2017 from doi:10.1080/03075079.2015.1124851.

Sen, Vicheth: "Cambodia's higher education structure and the implications of the 2015 ASEAN Economic Community". CDRI Annual Development Review 2012-13, 8, 2013, pp. 24-32.

Sen, Vicheth: "Hybrid governmentality. Higher education policymaking in postconflict societies. A perspective on Cambodia". Paper presented at the Annual Conference of the Comparative and International Education Society, Vancouver, British Columbia, Canada, 2016.

Sen, Vicheth: "Cambodian Higher Education. The Constraining Effects of Traditional Values. Issues and Reforms in Higher Education's Socio-cultural and Political Order". In: Chhem, Rethy / McNamara, Vincent (eds.), Education in Cambodia. Springer, forthcoming.

Sen, Vicheth / Ros, Soveacha: Anatomy of Higher Education Governance in Cambodia. Working Paper \#86. Cambodia Development Resource Institute: Phnom Penh 2013.

Touch, Visalsok / Mak, Ngoy / You, Virak: "Governance Reforms in Higher Education. A Study of Institutional Autonomy in Cambodia”. In: Varghese, N. V. / Martin, Michaela (eds.): Governance Reforms in Higher Education. A Study of Institutional Autonomy in Asian Countries. International Institute for Educational Planning, UNESCO: Paris 2013, pp. 51-68.

Un, Leang / Sok, Say: "Higher Education Governance in Cambodia”. In: Bergan, Sjur / Egron-Polak, Eva / Kohler, Jürgen / Purser, Lewis / Spyropoulou, Athanassia (eds.): Leadership and Governance in Higher Education: Handbook for Decision-makers and Administrators. Raabe: Berlin 2014, pp. 71-94.

UNESCO Institute for Lifelong Learning: Global Inventory of Regional and $\mathrm{Na-}$ tional Qualifications Frameworks. Volume II: National and Regional Cases. UNESCO: Hamburg 2015, retrieved 20.03.2017 from: http://www.cedefop.europa. $\mathrm{eu} / \mathrm{de} /$ publications-and-resources/publications/2213-0. 
United Nations Development Program: Human Capital Implications of Future Economic Growth in Cambodia. Elements of a Suggested Roadmap. UNDP: Phnom Penh 2011.

Young, Michael F. D.: "National qualifications frameworks as a global phenomenon. A comparative perspective". Journal of Education and Work 16(3), 2003, pp. 223-237, retrieved 11.5.2017 from doi:10.1080/1363908032000099412.

Young, Michael F. D.: "Implementing National Qualifications Frameworks: Problems and Possibilities". In: Maclean, Rupert / Wilson, David (eds.): International Handbook of Education for the Changing World of Work. Springer: Dordrecht, Netherlands 2009, pp. 2917-2933. 
Regina Egetenmeyer and Monica Fedeli - 978-3-631-73704-0

Downloaded from PubFactory at 01/11/2019 10:08:46AM

via free access 


\title{
Vanna Boffo, Azeez Babatunde Adebakin \& Carlo Terzaroli
}

\section{Supporting entrepreneurship in higher education for young adults' employability: A cross-border comparative study}

\begin{abstract}
This paper presents a comparative analysis of theoretical aspects and policy statements concerning entrepreneurship in Italian and Nigerian higher education. It analyses the development of entrepreneurial education and concludes that both countries share common values. It therefore recommends integrating entrepreneurship as one pillar of future universities.
\end{abstract}

\section{Introduction}

The issue we discuss in this paper concerns an unaddressed aspect of adult education courses at the higher education level. It is traditionally closely related to economics and generally not so popular. Entrepreneurship represents a relevant aspect of young adults' educational process. The patchiness depends on the specific context in which the country is situated: we are fully aware, for example, that Italy does not have a culture of entrepreneurship at the higher education level, and that such a culture is still very young in Nigeria.

The policy statements of the European Commission nevertheless clearly say:

To bring Europe back to growth and create new jobs, we need more entrepreneurs. The Entrepreneurship 2020 Action Plan is the Commission's answer to challenges brought by the gravest economic crisis in the last 50 years. It is a blueprint for action to unleash Europe's entrepreneurial potential, remove existing obstacles and revolutionise the culture of entrepreneurship in the EU. It aims to ease the creation of new businesses and to create a much more supportive environment for existing entrepreneurs to thrive and grow. (European Commission, 2017, p. 3)

Following the analysis that focuses on the best higher education models for the development of global citizens, we should take into account the strategic challenge of work. We should not be simply interested in the issue of educational offerings. In fact, we know that higher education is everywhere involved in an improvement process to foster graduation rates; at the same time, we also recognise that employability is increasingly becoming a key issue for the reflection on university courses, especially in countries with high youth unemployment rates. As a matter 
of fact, both problems generate issues of social exclusion that impact on society and on young people's transition to adulthood as well.

Discussing social inclusion and citizenship for the quality of our future societies, demands that these categories be translated into human actions (Arendt, 1958) that identify the sense of being part of the same world. Adult education directly relates to human formation and, in this sense, entrepreneurship could represent one of its specific features, because it is an issue of education and its most effective application is at the higher education level. Even before discussing business, we should focus on entrepreneurship as a personal capability, as a skill (or soft skill) to be acquired to increase the quality of individual and social human life.

The Ancient Greeks already suggested the importance of self-formation. We could be able to understand self-formation changes, transformation, and evolutions in past centuries (Hadot, 2002). Nowadays, it is possible to talk about selfentrepreneurship as one aspect of being capable of self-formation in the same way that philosophy has provided self-wisdom 'guidelines'. What does self-formation mean? It denotes the ability to self-orient and self-guide, to identify goals; it means to be flexible and able to understand others; it means the sense of time and place in which you operate; it means to be capable to mentalise and anticipate context and institutional needs and the needs of people involved in them (Boffo, Del Gobbo, Gioli, \& Torlone, 2017). These elements represent the soft skills that employers seek during job interviews and the same life skills identified in many adult education studies (Epale, 2017). Soft skills can be learned, and they can be taught. However, university courses still don't know how to effectively teach the 'rare bird' of transdisciplinary skills.

Entrepreneurship is one key element of self-formation. We could consider it an element of higher education but also the final outcome of education itself. Anyhow, the close connection between disciplines, entrepreneurship, and education could be considered the first axis for the comparative study we elaborate in this paper. The second axis is represented by the conviction of the strong link between entrepreneurship and learning. You learn to become an entrepreneur, to understand the importance of undertaking work and doing so during your whole life (Federighi, 2013). Perhaps the university has lost sight of this last aspect. Who can become this driving force today? It is a crucial topic, especially in this age of uncertainty and liquidity, where barriers and new walls are erected to separate us from our neighbours, from migrants and, in general, from ourselves, too. These two axes guide the research on a marginalised category, which has been traditionally conceived as belonging only to the market field but is, conversely, directly related to the self, life, and work dimensions. That's why it is a key topic: 
because it concerns our students' and graduates' future lives. If we want to create an appropriate educational offer at the higher education level, we should be able to know also about entrepreneurship and its multifaceted variants, starting with self-entrepreneurship.

A glance at the European Commission's definition could provide a clear outline of this perspective: 'Entrepreneurship is an individual's ability to turn ideas into action. It includes creativity, innovation, risk taking, ability to plan and manage projects in order to achieve objectives.' (European Commission, 2006, p. 8).

The definition is a standpoint for higher education that considers employability part of the curriculum. In fact, universities are increasingly asked to support the development of those skills to bolster students' capability of navigating multidimensional working pathways with a renewed sense of entrepreneurship.

\section{Employability and entrepreneurship: Concepts and clarifications}

There are two basic approaches currently being adopted in the research on employability. One is the employment-centred approach; the other is the competence-centred approach (European Commission, EACEA, \& Eurydice, 2014). The employment-centred approach can broadly be defined as focused on the ability to gain employment and to maintain it. This definition only considers the outcome of getting a job, with no attention to the personal and professional development of the individual. On the other side, the competence-centred approach focuses on the skills and competence that students could develop during their higher education studies.

Clearly, employability implies something about the capacity of the graduate to be functional and productive in a job and is not to be confused with the acquisition of a job (Yorke, 2006). This standpoint is derived from the scientific work of Lee Harvey ${ }^{1}$, Mantz Yorke ${ }^{2}$, and the Higher Education

1 Lee Harvey is a former director of the Centre for Research and Evaluation at Sheffield Hallam University. He is currently a visiting professor at Copenhagen Business School. He cooperated with the UK's Higher Education Academy in many research programmes.

2 Mantz Yorke is Honorary Visiting Professor at Lancaster University. His research interests are predominantly connected to students' experiences of higher education, covering areas such as student success, employability, assessment, and retention. He worked at the UK's Higher Education Academy for many years. 
Academy ${ }^{3}$. They propose two interesting understandings of the concept, based on the importance of the university in the development of students' employability.

The definition by Harvey (2001) emphasises both individual and institutional roles in employability. On the individual side, employability could relate to 'the propensity of students to obtain a job' (Harvey, 2001, p. 98). On the institutional side, employability is a responsibility of higher education itself (Harvey \& Knight, 1996). Harvey clearly underlines that

in some institutions or parts of institutions, this employability-development is explicit and integral to the education provided and in others it is not. Medicine, nursing, social work and initial teacher training have programmes of study closely linked to learning in practice settings that are directly related to future employment. (Harvey, 2001, p. 99)

From this perspective, employability is a matter of learning (Taatila, 2010) and not just a simple indicator of employment.

In the same perspective, Yorke (2006) illustrates this point clearly. He defines employability as 'a set of achievements - skills, understandings and personal attributes that make graduates more likely to gain employment and be successful in their chosen occupations, which benefits themselves, the workforce, the community and the economy' (Yorke, 2006, p. 8). Overall, Yorke suggests focusing not only on the gain of employment but on a broader perspective that considers the successful contribution to the labour market, the economy, and the community. Hence, from a pedagogical perspective, it opens new pathways (such as the design of innovative university curricula and new specific educational programmes with the study courses) for the research on employability linked to the formative process of the subject.

It is necessary to clarify exactly what is commonly meant by entrepreneurship. In this sense, entrepreneurship is a matter of employability since it occurs in any worker, regardless of sector and specific content. In detail, it describes the ability of finding opportunities to create value through innovation (Moreland, 2006). That is why entrepreneurship could be understood as a key competence for students' employability, enabling them to act effectively in different contexts and to manage personal and professional challenges. In this sense, it is directly linked to specific skills (Kucel, Róbert, Buil, \& Masferrer, 2016) that could be bolstered at the higher education level.

3 The Higher Education Academy started working on employability in 2006 with a paper series. The works comprised Professor Peter Knight (Open University), Professor Lee Harvey (Sheffield Hallam University), Professor Stephen McNair (Surrey University), Dr Brenda Little (CHERI), Professor Kate Purcell (University of the West of England), Mike Hill (Graduate Prospects), and Val Butcher from the Higher Education Academy. Regina Egetenmeyer and Monica Fedeli - 978-3-631-73704-0 
Moreover, entrepreneurship continues to attract interest from both academics and policy makers, so much so that many universities now include entrepreneurship studies as part of their curricula. Similarly, empirical studies exploring the extent to which entrepreneurial education influences the decision to become an entrepreneur are steadily increasing (Peterman \& Kennedy, 2003).

Entrepreneurship is the act of risk-taking in the production of goods and services for profit maximisation. This process goes beyond ideation but also conceptualisation, enterprise creation, commercialisation, and business growth (Dionco-Adetayo, 2014). In Osemeke (2012), entrepreneurship refers to the process of enhancing entrepreneurial skills and knowledge through structured training and institution-building programmes. Maigida, Saba, and Namkere (2013) describe entrepreneurship as an ability to think creatively and become an effective problem solver. They believe that entrepreneurship is the practice of consistently converting goods and ideas into productive and profitable commercial ventures. According to Klaipeda Business School (2009), entrepreneurship is defined as the main skill necessary to conform to the conditions of the ever-changing knowledge and information society. This means that entrepreneurship is about the acquisition of skills relevant to the contemporary needs of the dynamic society.

Table 1: Perspectives on the nature of entrepreneurship.

\begin{tabular}{|l|l|}
\hline Creation of Wealth & $\begin{array}{l}\text { Entrepreneurship involves assuming the risks associated with the } \\
\text { facilitation of production in exchange for profit. }\end{array}$ \\
\hline Creation of Enterprise & $\begin{array}{l}\text { Entrepreneurship entails the founding of a new business venture } \\
\text { where none existed before. }\end{array}$ \\
\hline Creation of Innovation & $\begin{array}{l}\text { Entrepreneurship is concerned with unique combinations of } \\
\text { resources that make existing methods or products obsolete. }\end{array}$ \\
\hline Creation of Change & $\begin{array}{l}\text { Entrepreneurship involves creating change by adjusting, } \\
\text { adapting, and modifying one's personal repertoire, approaches, } \\
\text { and skills to meet different situations and demands. }\end{array}$ \\
\hline Creation of Jobs & $\begin{array}{l}\text { Entrepreneurship is concerned with employing, managing and } \\
\text { developing the factors of production, including the labour force. }\end{array}$ \\
\hline Creation of Value & $\begin{array}{l}\text { Entrepreneurship is a process of creating value for customers by } \\
\text { exploiting untapped opportunities. }\end{array}$ \\
\hline Creation of Growth & $\begin{array}{l}\text { Entrepreneurship is defined as a strong and positive orientation } \\
\text { towards growth in sales, income, assets, and employment }\end{array}$ \\
\hline
\end{tabular}

Source: Onwuka, Ugwu, \& Kalu (2014, p. 274)

Bassey and Archibong (2005) state that the goal of entrepreneurship education is to empower graduates (irrespective of their areas of specialisation) with skills 
that will enable them to engage in income-yielding ventures if they are unable to secure formal jobs. This is a reorientation from job seeking to job creation. Likewise, Cheng and Chan (2009) point out that entrepreneurship training increases entrepreneurial self-efficacy, self-employment, and a risk-taking attitude in the entrepreneur. It also creates enormous business opportunities and trains people with innovative enterprise skills to grasp the opportunities for starting new entrepreneurial activities (Cheng \& Chan, 2009).

The role of higher education institutions (HEIs) in solving problems of development through the production of skilled labour has received serious contributions in recent time across the world. HEIs are expected to become responsive to the demands of the labour market, in the context of an increasingly competitive, complex, and globalised knowledge economy. Postigo, Lacobucci, and Tamborini (2006) acknowledge the significance of higher education and the role it plays in entrepreneurial activity, stating that it is critical to attract young adults to entrepreneurship, especially as current industrial trends are towards a knowledge-based environment. However, since many of the factors that could unlock the employment potential of young adults are also on the demand side of the labour market, private sector development, including entrepreneurship and entrepreneurial activities, can be part of the solution (Brixiová \& Kangoye, 2014). This may, however, be achievable through vigorous entrepreneurial skills development and training especially in the context of higher education.

To facilitate an evolving understanding of entrepreneurship, continued research efforts that investigate the skills required by entrepreneurs are essential. This is because skills acquisition involves the development of a new skill, practice the way of doing things usually gained through training or experience. Studies have shown that skill acquisition is the most critical factor in the utilisation of entrepreneurship opportunities for self-employment (Ekpe, Razak, \& Mat, 2012). More importantly for economic prosperity in the twenty-first century, in which the entire world has become private sector-driven, possession of entrepreneurial skills is required to function productively.

\section{Cross-border comparison of innovation and entrepreneurial learning}

The execution, implementation, and practices of entrepreneurship education are observed to vary across regions and institutions. This paper therefore provides experiences in terms of implementation and practices from European (Italy) and African (Nigeria) perspectives. The choice of these countries was informed by the in-depth knowledge of the education system in the two countries, where the 
authors practise as researchers and teachers and engage in community services. Indeed, the authors shared their perspectives during the International Winter School that took place in Würzburg in February 2017. In this sense, the comparison is the joint effort to analyse and compare theoretical aspects and policy actions in both countries.

The implementation of a national strategy for entrepreneurship in Italy is strongly supported by the European Commission. The Entrepreneurship 2020 Action Plan, published in 2013, stresses the challenge of new and innovative entrepreneurs for Europe (European Commission, 2013) in the context of an economic downturn, started in 2008, which severely affected the global and continental economy. In this direction, the European Union tried to face these structural changes through incentives for competitiveness and growth (European Commission, 2013). Entrepreneurship represents one of the pillars of the Europe 2020 Strategy. As a matter of fact, an effective strategy for entrepreneurship 'creates new companies and jobs, opens up new markets, and nurtures new skills and capabilities' (European Commission, 2013, p. 3). The Entrepreneurship 2020 Action Plan identifies three areas for intervention:

1. entrepreneurial education and training to support growth and business creation;

2. strengthening framework conditions for entrepreneurs by removing existing structural barriers and supporting them in crucial phases of the business lifecycle; and

3. dynamising the culture of entrepreneurship in Europe: nurturing the new generation of entrepreneurs (European Commission, 2013, p. 5).

In detail, the plan intends to: 'unleash Europe's entrepreneurial potential; remove existing obstacles and to revolutionise the culture of entrepreneurship in Europe; ease the creation of new businesses; and create a much more supportive environment for existing entrepreneurs to thrive and grow' (European Commission, 2013, p. 5). Unfortunately, Italy has not completely adopted the Action Plan yet. Starting from school education, which provides the medium-term perspective on which entrepreneurship is rooted, there is still no national strategy for the development of an entrepreneurial mind-set in primary and secondary school (European Commission, EACEA, \& Eurydice, 2016). This is particularly important for creating a stimulating entrepreneurial environment, because

whether or not they go on to found businesses or social enterprises, young people who benefit from entrepreneurial learning, develop business knowledge and essential skills and attitudes including creativity, initiative, tenacity, teamwork, understanding of risk and a sense of responsibility' (European Commission, 2013, p. 6). 
In this sense, entrepreneurship is not just 'being an entrepreneur', but developing the capability to transform ideas into actions that increase employability, too (Komarkova, Gagliardi, Conrads, \& Collado, 2015).

The Italian government just adopted, at the national level, the definition of the entrepreneurship competence defined in the European Reference Framework for Key Competences in Lifelong Learning. The key competence is described as follows:

[A] sense of initiative and entrepreneurship refers to an individual's ability to turn ideas into action. It includes creativity, innovation and risk-taking, as well as the ability to plan and manage projects to achieve objectives. This supports individuals, not only in their everyday lives at home and in society, but also in the workplace in being aware of the context of their work and being able to seize opportunities, and is a foundation for more specific skills and knowledge needed by those establishing or contributing to social or commercial activity. This should include awareness of ethical values and promote good governance. (European Communities, 2007, p. 11)

At the higher education level, the Ministry of Education, University and Research (MIUR) and the Ministry of Economic Development (MISE) developed in 2012 a joint policy report called Restart, Italia! aimed at creating a stimulating learning environment for university students and bolstering the entrepreneurial and innovation culture. Among the policy proposals, the report suggests intervening on students' awareness about future trends and opportunities. The statement is based on the importance of interdisciplinarity (Morin, 2015) in the world of work. Thus, the report proposes two actions:

- the realisation of activities, programmes, and initiatives aimed at promoting and spreading the culture of innovation and entrepreneurship in schools ${ }^{4}$ and universities;

- the creation of Contamination Labs (C-Lab), as special learning environments for students, researchers, and young professionals from different study fields who desire to improve their own entrepreneurial ideas (Fusacchia et al., 2012).

Indeed, unlike the traditional incubators and accelerators, the C-Lab intends to create a space for creative thinking and innovative project design. The report also stated that 'the initiative could be regarded as a "step back", since it aims primarily to build a network that allows to gather the human capital needed for highly innovative projects' (Fusacchia et al., 2012, p. 107). From this perspective, the C-Lab is an experimental didactical project for higher education institutions.

4 As stated above, the strategy in school education has not been implemented yet. 
The implementation of Contamination Labs at Italian universities was supported by a public announcement of the Ministry of Education, University and Research (MIUR) allocating one million euros for the realisation of such labs at universities situated in poorly developed regions. Four C-Labs were established in 2014 (Mediterranean University in Reggio Calabria, Calabria University in Cosenza, University of Catania, and University of Naples 'Federico II'). In addition to these subsidised initiatives, four more C-Labs started at the University of Cagliari, University of Trento, Catholic University of Milan 'Sacro Cuore', and Polytechnic University of Marche Region in Ancona. The first cycle of the project (2015/2016) saw great success, with 635 participants and more than 1,000 candidates (Calenda, 2016) ${ }^{5}$. These students generated 17 projects that could be further developed. In 2016, the National Research Programme 2015-2020, published by MIUR, provided more funds for new C-Labs and a new public announcement that opened in December 2016 for implementation during the current year.

In Nigeria, the gloomy unemployment rate has brought about the introduction of entrepreneurship education at universities; a course meant to encourage undergraduates to try self-employment, self-reliance, and self-sustenance through enterprise skills. This is currently high on the country's national agenda, with the hope that it will provide alternative channels of employment for young adults. Entrepreneurship education at universities is a way of alleviating the challenges of unemployment. It is one of the most important drivers of job creation and economic growth. It is crucial for the development of vibrant small and mediumsized enterprises (SMEs) and an informal business sector with multiplying effects on the national economy.

The introduction of entrepreneurship training in higher education is a purposeful intervention by an educator in the life of the learner to impart entrepreneurial qualities and skills to enable the learner to survive in the world of business. Entrepreneurship training could be the most effective method to facilitate labour market placement for the graduate population. Studies in this area have indicated that such training could identify responsible individuals and transform them into job creators, or confront risky individuals and create work challenges for them (Urbano, Aponte, \& Toledano, 2008; Dionco-Adetayo, 2014; Akintola, 2014). Through such strategies, the unemployment rate and the rate of job placement failures could be reduced. Entrepreneurship training basically includes the philosophy of self-reliance through structured and formal conveyance

5 The data refers only to C-Labs financed by the Italian Ministry of Education and Research. There is no data available for the other projects. 
of entrepreneurial competencies, concepts, skills, and mental awareness, such as creating a new productive environment and promoting new sets of attitudes that are central to developing entrepreneurial culture (Alberti, Sciscia, \& Poli, 2004; Arogundade, 2011). The skills and competencies acquired in the process of this training should be for developing individuals' growth-oriented ventures. This is a reorientation from job-seeking to job creation.

However, the observed underlying problem in Nigeria is the fact that the training that young adults receive has not been fully successful in equipping them with desirable skills and competencies required for job creation, self-employment, and self-reliance, as evident in the high rate of unemployment in the country. The Federal Government of Nigeria (2004) in National Policy on Education, section 8, sub-section 59(d), emphasises the acquisition of both physical and intellectual skills to prepare prospective graduates to be self-reliant and useful members of the society. The actualisation of this goal, as reported by Owusu-Ansah and Poku (2012), has been largely determined by theoretical knowledge acquisition without functional skills. This implies that the structure and content of formal education in most developing economies, including Nigeria, is designed to prepare young adults for corporate jobs without emphasising creativity and entrepreneurialism (Ikpesu, 2014). Meanwhile, this negates the drive for economic development in a nation such as Nigeria.

To make up for the inadequacies of addressing the unemployment problem, various governmental and non-governmental organisations have initiated policy programmes through support agencies such as the National Office for Technology Acquisition and Promotion (NOTAP)-1979, National Directorate for Employment (NDE)-1987, Raw Materials \& Development Council (RMDC)-1987, National Poverty Eradication Programme (NAPEP)-2001, and Small and Medium Enterprises Development Agency (SMEDAN)-2003. More recently, the Youth Enterprise with Innovation in Nigeria (YouWIN)-2011, the Subsidy Reinvestment and Empowerment Programme (SURE-P)-2012 and the Graduate Internship Scheme (GIS) programmes were introduced to promote entrepreneurship skills and address the challenges of unemployment among Nigerian young adults.

However, Ebiringa (2012) argues that many of these policy interventions aimed at stimulating entrepreneurship development via small and medium-scale enterprises in Nigeria have always failed and calls for a more inclusive approach. To this end, the National Universities Commission (NUC) in 2004 organised a workshop on 'Entrepreneurship for Nigerian Universities' for all federal universities in the country with the aim of inculcating an entrepreneurial spirit and mind-set in undergraduate students, improving the capacity of youths, developing positive 
independent and innovative thought, and stimulating future graduates towards venture and wealth creation.

The NUC workshop produced a draft curriculum on entrepreneurial studies for Nigerian universities. The Federal Government of Nigeria (FGN), through the Ministry of Education (MoE) in conjunction with NUC, consequently approved the establishment of Entrepreneurship Study Centres (ESCs) at all federally owned universities across the country, to be funded by the Education Trust Fund (ETF). The ministry also approved the establishment of a project implementation committee to fast-track the institutionalisation of entrepreneurship education at the nation's universities (Pulka, Rikwentishe, \& Ibrahim 2014). The primary role of the ESCs is to stimulate entrepreneurial competencies among students, staff, and the community.

Based on the established structures, many universities have initiated entrepreneurship education programmes to reverse the graduate unemployment trend by giving students the needed training in entrepreneurial skills, enabling them to set up businesses and to consider self-employment as a viable career option.

The policy projection for the first four years (2006-2010) of establishing entrepreneurship programmes at Nigerian universities was that at least 50,000 graduates would complete entrepreneurship training with sufficient entrepreneurial skills. Out of the projected 50,000 trainees, it was equally presumed that at least 10,000 graduates would be self-employed and possibly provide employment opportunities (Akintola, 2014). But today, there is no substantial data to reflect the exact number of students who were either self-employed or created jobs as employment opportunities for others. In no small measure, this leaves much to be desired about the efficacy of the programme at Nigerian universities.

Table 2: Comparison between entrepreneurship in Italy and Nigeria.

\begin{tabular}{|l|l|l|}
\hline Category & Italy & Nigeria \\
\hline $\begin{array}{l}\text { Labour } \\
\text { Market/Employment } \\
\text { Rate }\end{array}$ & $\begin{array}{l}\text { High level of Youth } \\
\text { Unemployment Rate }\end{array}$ & $\begin{array}{l}\text { High level of Youth } \\
\text { Unemployment Rate }\end{array}$ \\
\hline Aims & $\begin{array}{l}\text { Self-Employment and Job } \\
\text { Placement }\end{array}$ & $\begin{array}{l}\text { Self-Employment and } \\
\text { Job Placement }\end{array}$ \\
\hline $\begin{array}{l}\text { Name of Entrepreneurial } \\
\text { Programme }\end{array}$ & Contamination Lab (C-Lab) & $\begin{array}{l}\text { Entrepreneurship Study } \\
\text { Centres (ESC) }\end{array}$ \\
\hline Year of implementation & 2012 & 2006 \\
\hline Institutional Promoters & $\begin{array}{l}\text { Ministry of Economic } \\
\text { Development and Ministry } \\
\text { of Education, University and } \\
\text { Research }\end{array}$ & Ministry of Education \\
\hline
\end{tabular}




\begin{tabular}{|l|l|l|}
\hline Category & Italy & Nigeria \\
\hline $\mathbf{N}^{\circ}$ Participants & $\begin{array}{l}635 \text { students/graduates in } \\
2015 / 2016^{1}\end{array}$ & $\begin{array}{l}50,000 \text { graduates } \\
(2006-2010)\end{array}$ \\
\hline Assessment of Results & $\begin{array}{l}\text { The Ministry of Economic } \\
\text { development registered 17 } \\
\text { projects developed by C-Labs in } \\
2015 / 2016^{2}\end{array}$ & $\begin{array}{l}\text { No substantial data } \\
\text { available }\end{array}$ \\
\hline Approach & $\begin{array}{l}\text { Learning-oriented and } \\
\text { Projectoriented }\end{array}$ & Learning-oriented \\
\hline
\end{tabular}

Source: Authors' own

\section{Analysis of differences and similarities}

In presenting the juxtaposition of situations in the two countries, some differences and similarities concerning the development of entrepreneurial education in Italy and Nigeria emerge. The unemployment rates of young adults in both labour markets represent the first common point. As a matter of fact, both countries started implementing an entrepreneurship strategy as an action for raising job opportunities. In this sense, the awareness about young adults' issues facing the transition from university to work is the basis for the design of specific measures in that field.

Equally, the aims of Italian and Nigerian strategies rely on the expected outcomes of fostering students' and graduates' employability. What both governments want to disseminate is a broad conception of entrepreneurship, directly linked to employability. Moreover, both C-Lab (Italy) and ESCs (Nigeria) are ambitious learning programmes aimed at spreading the culture of innovation, the development of entrepreneurial competencies, the capability to identify opportunities in different contexts, and the ability to elaborate new ideas for new start-ups and complex organisations.

These experiences present a different approach concerning the design and the structure of the institutional framework. On the one hand, the Italian C-Lab was a young project, created only in 2012 and offering at this point only two announcements for its implementation at universities. On the other hand, Nigerian ESCs started in 2006 and have already reached a well-established level of efficacy and dissemination. Indeed, the institutional promoters revealed some differences between the two strategies. In the Italian experience, the cooperation between the Ministry of Economic Development and the Ministry of Education, University and Research is a sign of new and innovative cooperation between the economic 
and educational approaches at the higher education level. This aspect could be underlined also in terms of participants and results.

Despite the dissimilar starting point of the two strategies, differences could be detected concerning the participation of students, revealing very divergent levels of dissemination at universities (50,000 former participants in five years of the Nigerian strategies against only 635 in the first Italian cycle). Moreover, the technical report elaborated by the Italian Ministry of Economic Development (Calenda, 2016), which gives strong attention to impact and results as opposed to the lack of substantial data in Nigeria, could illustrate the presence of two different standpoints. In fact, we hypothesise that these final elements symbolise two different approaches. The Italian approach is oriented towards both innovative learning pathways and project outcomes, whereas the Nigerian one is directly focused on learning and competencies, without specific measurement (Akintola, 2014) of the efficacy of the project, as measured by the creation of new companies, for example.

\section{Conclusions and implications for research, policy and practice}

At the end of this reflective and comparative activity, we reached a clear touch point. The relationship between the need to foster entrepreneurship learning pathways at the higher education level and the need to combine them with goals is directly linked to the world of work.

It seemed really interesting to identify synergies between adult education, employability, and entrepreneurship. As stated above, this relationship is not commonly analysed in scientific research and, moreover, educational policies and strategies do give it the emphasis it deserves. Even today, discussions about business inevitably call into question the pursuit of profit. It is a deeply rooted way of thinking that has characterised the Western world for most decades of the twentieth century. The current debate on enterprise, by contrast, suggests that we are going beyond the ideological barriers that triggered wars, divisions, barriers, mourning, and pain.

Entrepreneurship should be linked to the concepts of democracy and responsibility (Jonas, 1984); it cannot operate without the ethical principles that will allow us to look at the future, in Europe and in Africa as well. From the research point of view, therefore, the ethical imperative of the principle of responsibility is the main standpoint from which to explore the world, starting from civil and social conditions. The imperative of responsibility, as formulated by Jonas in the late 1970s, inspires the presence of entrepreneurship in Higher education. 
In fact, values share the comparative pathways more than the specific contents of learning.

Research can therefore be oriented towards: (1) the creation of alternative didactics capable of (2) generating ideas and (3) supporting the creativity of each student. Moreover, research should be capable of (4) identifying the perspectives of the educational programme by monitoring and evaluating graduates' careers, and of (5) providing solutions in line with local, national, and international needs. With regard to the relevance of entrepreneurship as a crosscutting and inter-disciplinary idea, a glance at the university of the future could summarise these points.

Practical activities have already been pointed out:

1. the creation of shared co-working spaces;

2. the presence of idea-generation laboratories;

3. the implementation of mentorship activities for single students or groups wishing to advance their business ideas;

4. the organisation of transversal courses aimed at understanding business models;

5. the statement of work as one of the pillar of university missions;

6. the valorisation of work as the result of study and research.

This second part should identify the idea that work is the driving force of higher education. If the university of the twentieth century became a mass university, and also a social elevator and a place of cultural growth, the university of the twentyfirst century must be developed as the space for future ideas. It must become the centre for elaborating human values and ideals that focus on shared work, but also on decent work for all people.

In conclusion, we focus on educational policy guidelines. Mainly in Europe, too little thinking is devoted to innovation, work generation, and job diversification. Looking at the economic downturn that involved the whole world, we notice that most countries have no effective solutions for youth unemployment, particularly in Southern Europe. In this sense, higher education has to do more and better to provide young adults with useful and applicable skills, to make life-planning a central aspect of each student's experience in our courses. Moreover, we must educate men and women able to engage in dialogue in a new world: As Edgar Morin has said, a new education is still possible (Morin, 2015). Since the university is a place of learning, the revolution of 'learning entrepreneurship' is a new target to be reached and improved as a goal for the future. 
Each teacher, as an actor of this new storytelling in the universities, should reinforce his/her disciplinary methods and contents to strengthen the transformation that is naturally inscribed in every educational process.

\section{References}

Akintola, Olugbenga A.: "Policy Thrust on Education in Entrepreneurial Education. Trends, Implementation Gaps and Remedies”. In: Emunemu, Benedict / Akinwumi Femi (eds.): Educational Management in Africa. The Department of Educational Management, University of Ibadan: Ibadan 2014, pp. 446-468.

Alberti, Fernando / Sciscia, Salvatore / Poli, Alberto: "Entrepreneurship Education. Notes on an Ongoing Debate". Proceedings of the 14th Annual International Entrepreneur Conference. University of Napoli Federico, Italy, 4-7 July, 2004.

Arendt, Hannah: The Human Condition. The University of Chicago Press: Chicago 1958.

Arogundade, Babatope B.: "Entrepreneurship education. An imperative for sustainable development in Nigeria". Journal of Emerging Trends in Educational Research and Policy Studies 2(1), 2011, pp. 26-29.

Bassey, Ubong U./ Archiving, Isreal A.: "Assuring quality graduate output through entrepreneurial oriented education in Nigeria universities". Nigerian Journal of Curriculum Studies 12(3), 2005, pp. 18-23.

Boffo, Vanna / Del Gobbo, Giovanna / Gioli, Gaia / Torlone, Francesca: "Employability Processes and Transition Strategies in Higher Education. An EvidenceBased Research Study". In: Boffo, Vanna / Fedeli, Monica / Lo Presti, Francesco / Melacarne, Claudio / Vianello, Michelangelo: Teaching and Learning for Employability: New Strategies in Higher Education. Pearson Italia: Milan-Turin, 2017, pp. 161-204.

Brixiová, Zuzana / Kangoye, Thierry: "Youth Employment in Africa: New Evidence and Policies from Swaziland”. In: Malo, Miguel / Sciulli, Dario (eds.): Disadvantaged Workers: Empirical Evidence and Labour Policies. Springer International: Cham 2014, pp. 85-125.

Calenda, Carlo: Relazione annuale al Parlamento sullo stato di attuazione e sull'impatto della policy a sostegno delle startup e delle PMI innovative. 2016, retrieved 18.04.2017 from https://goo.gl/PyEiOX.

Charters, Alexander N.: Comparative Studies in Adult Education - A review. Paper presented at the World Congress of Comparative Education, Prague, 8 June 1992, retrieved 10.01.2017 from http://files.eric.ed.gov/fulltext/ED351449.pdf.

Cheng, Min-Yuan / Chan, Wesley: “The effectiveness of entrepreneurship education in Malaysia". Education and Training 51, 2009, pp. 555-566. 
Dionco-Adetayo, Erlinda: Entrepreneurship Education: A Panacea to Graduate Unemployment? 269th Inaugural Lecture Series, Obafemi Awolowo University, Ile-Ife, Nigeria. OAU Press: Ile-Ife 2014.

Ebiringa, Oforegbunam T.: "Perspectives. Entrepreneurship development \& growth of enterprises in Nigeria". Entrepreneur Practice Review 2(2), 2012, pp. 31-35.

Ekpe, Isidore / Razak, Razli / Mat, Norsiah: "Loan access, skill acquisition, bonding and the moderating effect of self-confidence on women entrepreneurs' business performance. A case of Nigeria". International Journal of Business and Management Studies 4(1), 2012, pp. 77-85.

European Commission: Recommendation of the European Parliament and of the Council of 18 December 2006 on key competences for lifelong learning (2006/962/ EC), retrivied 08.09.2017, from http://eur-lex.europa.eu/legal-content/EN/ TXT/PDF/?uri=CELEX:32006H0962\&from=EN.

European Commission: Entrepreneurship 2020. Action plan reigniting the entrepreneurial spirit in Europe. Communication from the Commission to the European Parliament, the Council, the European Economic and Social Committee and the Committee of the Regions. COM (2012) 795 final, 2013, retrieved 17.04.2017,from https://goo.gl/WCmgGo.

European Commission: The Entrepreneurship 2020 Action Plan. 2017, retrieved 29.05.2017 from https://ec.europa.eu/growth/smes/promoting-entrepreneur ship/action-plan_it.

European Commission / EACEA / Eurydice: Modernisation of Higher Education in Europe: Access, Retention and Employability. Eurydice Report. Publications Office of the European Union: Luxembourg 2014.

European Commission / EACEA / Eurydice: Entrepreneurship Education at School in Europe. Eurydice Report. Publications Office of the European Union: Luxembourg 2016.

European Communities. The Key Competences for Lifelong Learning - A European Framework. Publications Office of the European Union: Luxembourg 2007.

Federal Government of Nigeria. National Policy on Education (4th ed.). National Education Research Development Council: Lagos 2004.

Federighi, Paolo: Adult and Continuing Education in Europe. Using Public Policy to Secure a Growth in Skills. Publications Office of the European Union: Luxembourg 2013.

Fusacchia, Alessandro / Di Camillo, Andrea / D'Elia, Annibale / Solda-Kutzmann, Donatella / Pozzi, Enrico / Carcano, Giorgio / Ragusa, Giuseppe / De Biase, Luca / Magrini, Massimiliano / Mariani, Mario / Barberis, Mario / Donadon, 
Supporting entrepreneurship in higher education for young adults' employability 139

Riccardo / Biffi, Selene. Restart, Italia! Why we Have to Restart from Youth, Innovation and Startups. 2012, retrieved 15.04.2017 from https://goo.gl/e3WMJ5.

Hadot, Pierre: Esercizi Spirituali, Einaudi: Turin 2002.

Harvey, Lee / Knight, Peter: Transforming Higher Education. The Society for Research into Higher Education and Open University Press: Buckingham 1996.

Harvey, Lee: "Defining and measuring employability". Quality in Higher Education 7(2), 2001, pp. 97-110.

Ikpesu, Oghenerukevwe: "Entrepreneurial human capital development and economic future of Nigerian graduates”. Developing Country Studies 4(12), 2014, pp. 193-198.

Jonas, Hans: The Imperative of Responsibility. University of Chicago Press: Chicago 1984.

Klaipeda Business School: Improvement of Entrepreneurial Skills in a Multicultural Environment. Erasmus Intensive Programme Project. 2009, retrieved 12.01.2016 from http://www.kvam.lt/erasmus-ip-projec.

Komarkova, Ivana / Gagliardi, Dimitri / Conrads, Johannes / Collado, Antonio: Entrepreneurship Competence: An Overview of Existing Concepts, Policies and Initiatives. Publications Office of the European Union: Luxembourg 2015.

Kucel, Aleksander / Róbert Péter / Buil, Màrian / Masferrer, Núria: "Entrepreneurial skills and education-job matching of higher education graduates". European Journal of Education 51(1), 2016, pp. 73-89.

Maigida, James / Saba, Thomas / Namkere, Udoudo: "Entrepreneurial skills in technical vocational education and training as a strategic approach for achieving youth empowerment in Nigeria". International Journal of Humanities and Social Science 3(5) 2013, pp. 303-310.

Moreland, Neil: Entrepreneurship and Higher Education. An Employability Perspective. The Higher Education Academy: York 2006.

Morin, Edgar: Insegnare a vivere. Manifesto per cambiare l'educazione. Raffaello Cortina: Milano 2015.

Onwuka, Ebele / Ugwu, Kenechukwu / Kalu, Arunsi:“The effect of policy measures on entrepreneurship development analysis of Nigeria's experience”. European Journal of Business and Management 6(23), 2014, pp. 270-276.

Osemeke, Monday: "Entrepreneurial development and interventionist agencies in Nigeria". International Journal of Business and Social Science 3(8), 2012, pp. 255-265.

Owusu-Ansah, Wilberforce / Poku, Kofi: "Entrepreneurship education. A panacea to graduate unemployment in Ghana". International Journal of Humanities and Social Science 2(15), 2012, pp. 211-220. 
Peterman, Nicole E. / Kennedy, Jessica: "Enterprise education. Influencing students' perceptions of entrepreneurship". Entrepreneurship: Theory and Practice 28(2), 2003, pp. 129-145.

Postigo, Sergio / Iacobucci, Donato / Tamborini, Maria: "Undergraduate Students as a Source of Potential Entrepreneurs. A Comparative Study between Italy and Argentina". In: Alian Fayolle / Heinz Klandt (eds.): International Entrepreneurship Education, Issues and Newness. Edward Elgar: New York 2006, pp. 218-240.

Pulka, Buba / Rikwentishe, Rimamnde / Ibrahim, Bello: “An evaluation of students' attitude towards entrepreneurship education in some selected universities in North East Nigeria". Global Journal of Management and Business Research 14(8), 2014, pp. 1-8.

Taatila, Vesa P.: "Learning entrepreneurship in higher education". Education + Training 52(1), 2010, pp. 48-61.

Urbano, David / Aponte, Marines / Toledano, Nuria: "Doctoral education in entrepreneurship. A European case study". Journal of Small Business and Enterprise Development 15, 2008, pp. 336-347.

Yorke, Mantz: Employability in Higher Education. What It Is - What It Is Not. The Higher Education Academy: United Kingdom 2006. 


\section{Employment Perspectives and Professionalisation in Adult Education}


Regina Egetenmeyer and Monica Fedeli - 978-3-631-73704-0

Downloaded from PubFactory at 01/11/2019 10:08:46AM

via free access 
Christin Cieslak, Rute Ricardo, Jenny Fehrenbacher, Bharti Praveen \& Kira Nierobisch

\title{
Between educating and teaching: The professional identity of adult educators. A transnational comparison between Portugal, India, and Germany
}

\begin{abstract}
Concepts of professional identity define the socialisation of adult educators, if only implicitly. This article presents a comparative, transnational discussion of the main theories and concepts of academic professionalisation and the emergence of a professional identity, as an individual or as a profession.
\end{abstract}

\section{Introduction}

Questions regarding personal professional identity are essential in the context of academic professionalisation. In andragogical settings, these are framed by different conditions and demands: by the curricular foundation, the institutional requirements, the expectations on the part of participants, and by how the role of an adult educator itself is understood. The understanding of learning and teaching plays a central role. Adult educators see themselves - according to their own transcultural and learning experiences and academic socialisation - as teachers, learning guides, consultants, or role models. These forms of identity correspond to each individual view of the profession and what it includes. This understanding of identities and roles, paired with different concepts of learning and teaching, biographic experiences, and theoretical discourses, also influences the identity development of students in adult education.

The article starts by providing an overview of the concepts and theories of professional identity, followed by a comparison of these concepts in India, Germany, and Portugal. We will show that adult education in India is dominated by an endeavour to foster literacy and numeracy, whereas in Germany, it is professional development in an academic context that takes precedence. Portugal, however, accentuates adult education in association with political-emancipatory aspirations, which will be presented through a current study. This is followed by a transnational comparison of the different concepts and development of professional identity in the three countries. In conclusion, we will present the core 
144 Christin Cieslak, Rute Ricardo, J. Fehrenbacher, Bharti P. \& Kira Nierobisch

dimensions of professional identity in adult education and point out potential issues to be addressed.

\section{Professional identity}

The concept of professional identity includes beliefs, behaviours, values, and motives through which a person defines himself or herself in a professional role. Bierema (2011) defines professional identity as a result of professional socialisation:

Professional socialisation involves building specialised knowledge and skills, incorporating a sense of occupational identity, internalising the norms of the profession, and adapting the values and norms into individual behaviour and self concept. (Bierema, 2011, p. 29)

Cooper and Olson (1996) point out that professional identity is multifaceted. Historical, sociological, psychological, and cultural factors may all influence the professional self-concept of adult educators. Professional identity in adult education takes two forms (Bierema, 2011, p. 30). The first is how one conceives individual professional identity as an adult educator. This includes individual identification with an adaptation to the field and the culture of adult education:

Since there are many types of adult education, you might be more inclined to identify yourself as a literacy teacher or health educator or human rights activist or human resource developer or instructional designer, rather than as an adult educator. (p. 30)

The second form of professional identity in adult education according to Bierema is how the field itself creates, maintains, and changes its professional identity. In other words, there is a public face with a relatively agreed upon discourse, research, and practice that has been established (p. 30). According to Cruess, Cruess, and Steinert (2016), professional identity includes five different dimensions: knowledge, competences, performance, action, and identity. Performance in particular demonstrates the behaviours expected of adult educators, and their identity consistently demonstrates the attitudes, values, and behaviours like a 'biographical mind set' (p. 181). Professional identity itself is always a combination of personal and social identity; it is a subjective effort of lifelong learning and identification in which individuals, with their life history, their gender, and so on, become able to perform an already existing task to some extent by acquiring already existing knowledge and using it to create their own practice and identity (Salling Olesen, 2001a, 2001b). From this perspective, professional identity can be described as the combined effort of learning processes and the ongoing struggle with the demands of a task - integrated into one's own general life experience. (Salling Olesen, 2006, p. 5). Professional identity, furthermore, may consist of many sub-identities that 
might conflict or align with each other (Mishler, 1999). According to Mishler, it is therefore better to recognise that a plurality of 'subidentities' exists in the definition of identity.

It has thus been shown that there are different dimensions, including socialisation, biography, knowledge, (inter)action, competences, and theoretical discourses, each of which influences the development of professional identity. Therefore, the developmental process is part of the professionalisation of adult educators and adult education itself.

Within the German discourse on professionalisation, three different terms are commonly used: Professionalität, Profession, and Professionalisierung. They are equivalent to the English terms professionalism, profession, and professionalisation. Against this background, profession is generally understood as an academic occupation, including successful completion of a university education. The term profession also includes dealing with a central social problem and the necessity to implement required knowledge systematically (Nittel, 2000, pp. 15-17). According to Schwendenwein, there are seven structural features of a profession: existence of professionally relevant research, a corresponding legal base, consideration and observation of job-specific key objectives, existence of a professional codex, existence of an intrinsic representation of professional interest, participation in continuing education by active members, and unrivalled exercise (Schwendenwein, 1990, p. 360). Further characteristics of a profession are to act within an occupation usually including a certain degree of autonomy. The term professionalisation (Professionalisierung), however, refers to the processes of occupationalisation, individual formation, and continuing education within a job. Furthermore, we can distinguish between collective professionalisation and individual professionalisation. Collective professionalisation includes interrelated process levels, such as the institutional expansion of continuing education or the academisation of adult education. Within the individual process, the focus is on the educational process as a personal change and maturing process. Professionalism (Professionalität) is understood as skilful occupational aspiration and as an indicator of high-quality work. This is the base for professional action: to use specific knowledge and competence to interpret and deal with unstructured situations. It means making situation-based and personalised use of knowledge and competence. Professionalism further includes the professional self with his or her values, goals, knowledge, and so forth. Furthermore, the term includes a wide pedagogical repertoire of actions to ensure the successful handling of work assignments (Nittel, 2000, pp. 15-17). 
In summary, all three terms include aspects of 'professional identity'. Profession refers to a professional code and the personal interest in further education. Within individual professionalisation, personal change and maturing processes are important issues. Professionalism includes the professional self and the connection between knowledge and skills (Schütz, 2009, pp. 81-92). Personal interest, the maturing process, personal development, and the professional self are in the focus of the discourse. This means that by thinking about professional identity in adult education, the discourse on professionalism seems to be an important starting point for further analysis and consideration.

\section{Adult education: Influential concepts and practices. Examples from Germany, India, and Portugal}

This following section adopts a qualitative research methodology based on the comparison of three case studies regarding professional identity in India, Germany, and Portugal. Besides the common main concept, each country adopted a 'way of work' and presented a different example within their case.

In the case of India, the country report took a historical and descriptive approach. In the case of Germany, after contextualisation and with the specific aim to analyse how professionalisation and especially professional identity is implemented in academic study programmes of adult education, three different module manuals were analysed. For Portugal, several basic concepts related to the professional identity of adult educators, functions, and competences were defined on the basis of an empirical study. These different approaches, concepts, and practices have an immense influence and impact on the core aspects of the professional identity of an adult educator. This difference between the three approaches is related to the qualitative methodology used; it is further related to the historical context and the development of each country. In the following, we present different aspects of adult education in India, Germany, and Portugal and shed light on the similarities and differences between the three countries.

\section{India}

In India, teachers, instructors, labour educators, human resource developers, and the like are considered adult educators. 'The scope of adult education is daunting in its many forms and contexts, making this work challenging' (Bierema, 2011, p. 22). Lifelong learning has been an integral part of Indian culture; however, India has yet to develop a comprehensive framework for lifelong learning (Shah, 2017). 
In ancient history, Indians seeking an education went to 'ashrams' - institutions roughly comparable to colleges. There, a guru functioning as teacher provided religious knowledge as well as ethical and moral values. However, adult education in modern India has been reformed. During the 1960s, reformers contributed to social change and brought down barriers for women and the poor to participate in education (Shah, 2017). Nowadays, India is still a country with strong beliefs in a religious approach to education, and the Indian majority therefore accepts sweeping change justified by religious reasoning. Grassroots projects and basic education are prevalent, aimed at enhancing the percentage of literate and numerate adults in India and resulting in efforts to educate a vast number of people and to support people-teach-people approaches. As Shah (2010, p. 56) points out, India is the second most populous country in the world with a population of 1,028 million, but the gross enrolment in higher education is only 10 per cent. The demographic data show that 68.9 per cent of the Indian population is below the age of 35 (Shah, 2010). Mainly because of these factors,

the focus of India's adult and lifelong learning programmes continues to be on adult basic literacy and continuing education for the younger age group. However, the scope of adult education policy and programmes in India is not limited to imparting basic literacy and post literacy to learners, but includes skills training, inculcation of civic values of national integration, environmental conservation, women's equality, and observance of the small family norm. (Shah, 2010, p. 81)

In spite of having the third-largest education system in the world with 358 universities, 153 research institutions, and 2,019 teacher-training colleges, and an increase in literacy rates from 52.11 per cent to 64.84 per cent during the decade from 1991 to 2001, there is a massive backlog of 304.11 million neol-iterates in the country, comprising nearly 30 per cent of global neo-literates (Shah, 2010). Moreover, it is estimated that there are 110 million neo-literates in the country:

Although the importance of lifelong learning was never overlooked in Indian education policy documents, and the policy statement on the National Adult Education Programme (1978) considered continuing education as an indispensable aspect of the strategy of human resource development and of the goal of creation of a learning society, there has been practically no shift from the exclusive emphasis on adult literacy. (Shah, 2010, p. 57)

Despite the changing concept of adult education from basic literacy to civic literacy, functional literacy and developmental literacy and various short-term programmes undertaken during the second half of the twentieth century, the thrust of the adult education programmes in India continues to be on the eradication of illiteracy among adults, Shah (2017) emphasises. 
As Shah (2010, p. 60) further points out, the prevalent tendency in adult and lifelong learning in India has been to design the different programmes as shortterm projects. It is assumed that such short programmes can be implemented with professionally trained staff, regular pay, and allowances. Hence, there has been hardly any serious thinking on the professionalisation of adult education. Indian adult educators have not yet carved a niche for themselves among the important professions. The majority of practitioners of adult education do not have a homogeneous professional background. There are no qualifying examinations to become an adult educator. 'Due to the voluntary nature of programmes, adult education as a profession is neither well-established nor well understood.' (Shah, 2010, p. 56) Therefore, Shah developed four categories of functionaries in adult education (Shah, 2010, pp. 60-61): Firstly, the teachers/instructors employed in university departments of adult education, academic staff at colleges, community colleges, and polytechnics or industrial training institutes. Secondly, trainers who were designated as programme coordinators and employed in state resource centres and NGOs. Thirdly, programme managers who are employed in governmental and non-governmental organisations, and, lastly, the 'grassrootslevel functionaries' working in continuing education centres. Hence, professional socialisation in India is also a developmental process of adult socialisation. This not only involves the recognition of an assumed identity by the outside world, it is also recognition of the identity within themselves and the non-deliberate projection of themselves in its terms referred to as internalisation and depicts the success of past socialisation, causing a new identity to emerge, much of which is formed through academic training (Bierema, 2010, p. 138).

\section{Germany}

The field and context of adult education in Germany is wide and diverse. Because of this heterogeneity, the discourse about professionalisation is intensive and long-lasting. Different research approaches are followed with regards to professionalisation in adult education, for example, evaluating the curricula of adult education graduation programmes and interviewing graduates of adult education programmes. (Egetenmeyer \& Schüßler, 2012, p. 7) A review of the most recent publications and the current discourse in adult education reveals research and discussions on professionalism, including professional identity and professional self. In the discussion on professionalisation, different approaches are pursued to define a competence-based framework for adult educators. Based on discussions during the 1990s, this framework includes personal competences, social competences, didactical competences, methodical expertise, as well as social 
and institutional competences (Bechtel 2008, p. 37), adapted or complemented (Rapold, 2006, p. 7).

In Germany, the economic sector in particular is strongly represented in the adult education field of practice. Especially within the last forty years, professional continuing education in Germany has been extensively discussed and thus gained importance. Demands on companies and opportunities in this sector have been growing. One reason for the increasing interest in professional continuing education is related to the motivation of the economy and employers, but it is also a highly discussed topic in politics (Bundesinstitut für berufliche Bildung, 2014, pp. 12-13). Adult educators in Germany are professionally active in a variety of fields. Various institutions such as the Volkshochschule (schools for adults providing continuing non-credit education) offer employment opportunities for adult educators in teaching, administration, and counselling positions. In addition, the consulting and services field for training and human resources has been developing and growing over the last decade. This is due to increased political interest in professional continuing education in the economic sector. Volkshochschulen were the starting point of a discourse on professionalisation in adult education. Nowadays, adult educators can work in various fields, as the profession is neither a clearly defined homogeneous social unit nor a standardised career model (Nittel, 2011, p. 487).

To find out how professionalisation and especially professional identity is implemented in academic study programmes of adult education, different module manuals were analysed. Three universities published their master's module manuals on their homepage. All three of the programmes analysed offer a four-semester master's programme with the same title, 'adult and continuing education'. The universities are public, and the programmes are research oriented. Different terms were identified in the manuals, including 'pedagogic professionalism,' 'professional pedagogical competence development,' 'professional pedagogical activity', and 'professional action competence.' However, the term 'identity' was not mentioned in any of the manuals. The following categories were found: professional codex and interest in further education, personal change and maturing process, professional self (professional knowledge, values, goals, techniques, professional languages, and professional responsibilities) and skills. This further shows that each university has its own thematic priority in its manual, such as values and ethics featuring strongly in seminar content, seminars and practical work on education research, or an emphasis on how to handle media content. All of the evaluated universities offered opportunities for optional internships. It was understood as an opportunity for students to gain practical experience, for instance through project 
work or by participating in research. The universities further emphasise self-study and independent, individual learning as part of their programmes, presumably to encourage and support students to follow their personal interests and motivations. This could be an important influential factor, enabling students to be more confident and certain of their chosen profession and to develop a professional identity.

\section{Portugal}

In Portugal, the fields of teaching and learning are understood in a broad sense. They include not only formal and non-formal education, meaning to learn within a structured and organised learning environment, but also the processes of development and learning in the context of work. In this sense, the phenomenon of adult education follows two principal approaches. Firstly, the approach defined by UNESCO (2009), characterised by the diversity and complexity of practices, participants, and organisations, and a second approach that is more visible in academic contexts.

Rothes (2003) points out that 'the expression 'educator (or trainer) of adults' [...] refers to a multitude of functions and new professional activities" (p. 56). Guimarães (2016) presents a variety of tasks and activities carried out by adult educators, which can be divided into two main dimensions. On the one hand, the technical-pedagogical and educational dimension involves monitoring, guidance and advice, the recognition and validation of skills, as well as support for the construction of the autobiography of adults (Guimarães, 2016). On the other hand, there is the dimension of organisation and procedural management. It includes primarily administrative activities (Guimarães, 2016). Because of the complexity and diversity of this profession, it is not yet possible to identify a strong professional identity (Carvalho \& Baptista, 2004).

To elaborate on the aforementioned points, the study Realities of Adult Educators in the South of Portugal (Ricardo \& Fragoso 2014) will be contextualized. One university in southern Portugal is following models of practice inspired by adult education principles. In this sense, content related to adult education makes a significant appearance in the curricular structure of this degree scheme (Educaçao Social). Critical educators such as Paulo Freire (1997), however, represent transversal references and an inspiration to social educators' training. By taking critical education or humanism as foundational paradigms for this programme of studies, the intentions are that professionals go beyond the old paradigms of social work (Ricardo \& Fragoso, 2014). Consequently, the study's main aim was to understand the professional situation of adult educators working in southern Portugal (Algarve), taking into consideration the perceptions of these professionals (graduated 
between 1998 and 2012). To that end, the study used a mixed method - a combination of an online survey (Ghiglione \& Matalon, 1997), 21 semi-structured interviews (Bogdan \& Biklen, 1994), and a focus group discussion. The different methods used in the research convey an idea of the main elements and categories that are related to the identity of the profession. The majority of the research participants were female (91\%) and young (56\% were between 25 and 30 years old). They had comparatively low salaries. 45 per cent earned between $€ 500$ and $€ 1000 ; 11$ per cent earned less than $€ 500$ per month, which they commented on by saying 'pockets empty, hearts full'. Generally, the educators surveyed claimed to be satisfied with their profession (even recognising that low salaries are an everyday problem). The main activities they performed were social diagnosis, designing and implementing processes, developing and guiding activities specifically designed for vulnerable groups, and psychosocial counselling. The educators surveyed indicated that they feel valuable to their institutions because of the characteristics of their global professional profile. Characteristics mentioned were the ability to work in multidisciplinary teams, to act as mediators, and to contribute to solving conflicts and to have a horizontal relationship with people (both individuals and communities), thus facilitating processes that aim to be empowering. It is important to stress that educators seem to try and do more in their work beyond providing simple assistance. Generally, they indicated that it is their professional duty to promote community participation through education and training and to help people to recognise their importance and abilities.

To perform their professional identity, educators needed to have several capacities and characteristics, both professional and personal. According to the survey and the interview analysis, the main personal characteristics of the adult educators were creativity ( $85 \%)$, autonomy $(73 \%)$, ability to plan ( $86 \%)$, humility (72\%), dynamic (93\%), and being a well-rounded person (74\%). The educators also indicated that some professional capabilities are empathy, the ability to listen, vocation, the ability to work with others in a team, good adaptability, problemsolving ability, and the ability to mediate.

\section{Comparison of the countries}

The following reflection will provide an insight into the developmental process of four core aspects affecting the identity of adult educators. These include the societal roots of adult education, the aim of adult education training and degrees, the different connotations of the terms educator and teacher, and the main fields of practice for adult educators. The objective of this activity was to work out potentially influential aspects that substantiate the identity of adult educators. The 
developed aspects were considered comprehensively in order to avoid limiting the discussion purely to the skills and competences of adult educators. They are intended to ensure a comprehensive view of adult educators' identity as well as the comparability of different countries.

During the first developmental phase, a preparatory report on each country was provided. The reports assured a general overview of the field of adult education professionals in each country. They gave a basic understanding of the cultural, structural, and functional differences in the field between Germany, India, and Portugal. The second developmental phase was conducted during a face-to-face working period in Würzburg, Germany. A subsequent in-depth reflection on the terminology used in the field of adult education professionals was carried out to further deepen the understanding of terminological nuances and to develop a comparative strategy. The analysis of the terminology used in Germany, India, and Portugal regarding adult education, adult learners, and adult educators, indicated profound differences in how the specific terms are understood and used in each country. Terms addressing or describing adult educators were used ambiguously and inconsistently. However, during the work session in Würzburg, it also became apparent that overlaps could be identified and further developed. This is the reason for the multitude of common terms examined. The examination based on the country reports provided an analysis of different publications on adult education and adult educators and a critical discourse within the consortium. Grouping together these terms showed how the used terminology not only failed to differentiate the affected professionals (e.g. learners, educators, politicians) but also the different levels of action (e.g. individual level, school level, national level). This indicated the necessity of incorporating a distinction between macro, meso, and micro levels and the assignment of terms to the respective levels. At the macro level, politics and policies were identified, as they provide the legal and financial basis of education and reach a level of generality in the field that other levels might not. Institutions and work contexts were determined to represent the meso level. They provide a certain compulsory frame for the individual involved, but follow the macro level regulations and standards. The micro level, therefore, stands for the individuals who are active in adult education, both inside and outside of organisations and institutions, since they represent the smallest unit in the field and are directly governed by the macro and meso levels. However, these levels should be understood as communicative and interactive, insofar as feedback is exchanged between them through means such as communiqués, surveys, and protests. In the final step, the developed generic terms were abstracted into components of a reference frame, providing a categorical model of comparison. 
By analysing the process and the results of the first and the second phase of the intensive workshops, four core aspects were identified. Parameters for the identification of these aspects were, amongst other things, the weighting and the impact in the countries compared. The four comparative core aspects are the societal roots of adult education, the aim of adult education training and degrees, the different connotations of the terms educator and teacher, and the main fields of practice for adult educators. After examining the roots and the position of adult education in Germany, India, and Portugal in each society, the view of adult education in each country became clearer, so that including this aspect into the analytical model was essential. In the process of analysing and discussing the terminology, it became evident that 'educator' and 'teacher' were transnationally the most frequently mentioned terms in the professional discourse and papers published on adult education. This indicated the necessity of clarifying the connotations of the terms 'educator' and 'teacher' in order to gain a comprehensive and comparable understanding of the adult education profession in Germany, India, and Portugal. Consequently, the aim of adult education training and degrees was seen as crucial to embedding the training of adult education professionals into its academic context in order to examine its identity-building potential. The main fields of practice for adult educators were included into the analytical model, as they provide some of the main indicators regarding the requirements in the adult education profession and, therefore, the professional identities potentially associated with them.

The following table summarises the application of the four comparative core aspects in keywords.

Table 1: Comparative model by categories and by country.

\begin{tabular}{|l|l|l|l|l|}
\hline & Roots & $\begin{array}{l}\text { Academic degree } \\
\text { in AE (main } \\
\text { goal) }\end{array}$ & $\begin{array}{l}\text { Terms: } \\
\text { Educator (E) \& } \\
\text { Teacher (T) }\end{array}$ & Fields of practice \\
\hline GERMANY & $\begin{array}{l}\text { Humanistic } \\
\text { Re-education }\end{array}$ & $\begin{array}{l}\text { Promotes } \\
\text { individualisation } \\
\text { and prioritisation } \\
\text { through the } \\
\text { student }\end{array}$ & $\begin{array}{l}\text { E: A person } \\
\text { working with } \\
\text { children or } \\
\text { adolescents; } \\
\text { development of } \\
\text { their personality } \\
\text { T: A person } \\
\text { spreading } \\
\text { knowledge in a } \\
\text { didactical setting }\end{array}$ & $\begin{array}{l}\text { Extensive, } \\
\text { ranging } \\
\text { from public } \\
\text { institutions such } \\
\text { as community } \\
\text { colleges to } \\
\text { corporate } \\
\text { environments }\end{array}$ \\
& & & & \\
& & & & \\
\end{tabular}


154 Christin Cieslak, Rute Ricardo, J. Fehrenbacher, Bharti P. \& Kira Nierobisch

\begin{tabular}{|c|c|c|c|c|}
\hline & Roots & $\begin{array}{l}\text { Academic degree } \\
\text { in } \mathrm{AE} \text { (main } \\
\text { goal) }\end{array}$ & $\begin{array}{l}\text { Terms: } \\
\text { Educator (E) \& } \\
\text { Teacher (T) }\end{array}$ & Fields of practice \\
\hline INDIA & Religion & $\begin{array}{l}\text { Enables } \\
\text { individuals to } \\
\text { work in AE and } \\
\text { social work }\end{array}$ & $\begin{array}{l}\text { E: A person } \\
\text { providing } \\
\text { instruction at a } \\
\text { basic level; follows } \\
\text { formal setting } \\
\text { T: A person } \\
\text { who teaches in a } \\
\text { formal learning } \\
\text { environment }\end{array}$ & 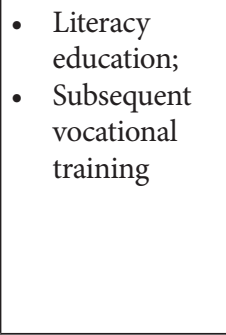 \\
\hline PORTUGAL & Humanistic & $\begin{array}{l}\text { Provides the } \\
\text { tools to develop } \\
\text { projects, research } \\
\text { and intervention }\end{array}$ & $\begin{array}{l}\text { E: A professional } \\
\text { whose work } \\
\text { is related to } \\
\text { humanistic } \\
\text { pedagogy; non- } \\
\text { formal education } \\
\text { T: A person who } \\
\text { teaches something } \\
\text { specific, e.g. a } \\
\text { certain topic, in } \\
\text { school } \\
\end{array}$ & 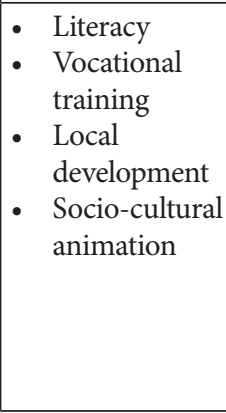 \\
\hline
\end{tabular}

Source: Authors' own

Based on the four core aspects, a comparison of Germany, India, and Portugal was conducted. A subsequent in-depth reflection on the terminology used in the field of adult education professionals was carried out with respect to the core aspects. The aim was to further deepen the understanding of terminological nuances and identify similarities and differences.

Adult education in India was found to have comparatively strong roots in religion, which mirrors Indian adult education. It is strongly driven by changes justified through religious morals and values. In Germany, the roots of adult education are highly influenced by a humanistic approach and the term Bildung. Although it is frequently translated as 'education', Bildung follows a more comprehensive approach, including aspects of an open mind and creativity. Adult education in Germany is defined by a wide variety of factors, such as the re-education programme after the Second World War. Compared to India, basic education in Germany is less prominent. Portugal is characterised by a humanistic approach as well. Marked by the dictatorship regime from 1926 to 1974, Portugal tried to rebuild itself with the support of associations and programmes like LEADER 
and EQUAL. These programmes, financed by the European Union, created some opportunities and projects that focused on participative methodologies, such as popular education, bottom-up approach, local development, and social intervention (Fragoso \& Guimarães, 2010).

Regarding the main goal of academic degrees in adult education, India strives to enable individuals to work in adult education and social work. As Indian adult educators primarily fight illiteracy and innumeracy, the fields of practice are mainly found in literacy education and subsequent vocational training. Academic degrees in adult education in Germany, however, are less narrow. Master's degree programmes include elective courses and internships, giving students more opportunities for individualisation and prioritisation. The possible fields of practice for adult educators are extensive, ranging from public institutions such as community colleges to corporate environments. Adult education graduates in Germany work as teachers, trainers, and in similar roles. In Portugal, adult education training generally provides the tools to develop and implement different projects, research and intervention. In this case, the framework of adult education intersects with community involvement, cultural animation, adult literacy, training of trainers, the recognition of acquired experience, and the management, organisation, and financing of training. Consequently, the goal of academic degrees in adult education in Portugal is more versatile than in India. Portugal supports a practiceoriented approach similar to that in Germany, enabling adult education graduates to individualise and prioritise through their studies. In Portugal, there are four main fields of practice: literacy (or second chance education), vocational training, local development, and socio-cultural animation (Canário, 1999). The fields are independent but can fit together, and interaction between them is possible.

The terms 'educator' and 'teacher' were identified as the most commonly used terms to name and address adult educators in the three countries. Although there is some overlap in the meanings of the terms, they refer to different characteristics and functions. In India, an educator is a person providing instructions at a basic level in a formal setting. In Portugal, an educator is primarily a professional whose work is related to humanistic pedagogy (Azevedo, 2011). In this sense, an educator would for the most part be engaged in non-formal education. In Germany, however, educators are mainly found working with children or adolescents supporting the development of their personality. In India, the term 'teacher' primarily refers to a person who teaches in a formal learning environment, such as a school. Although the same is applicable to the understanding of teacher in Germany, the term has a broader meaning and can be expanded to include any person spreading knowledge in a didactical setting. In Portugal, 'teacher' has a 
similar meaning, referring to a person who teaches something specific, such as a certain topic, in a specific context, such as a school. Looking at these distinctions between the meanings of educator and teacher, India is the country that shows the least differentiation between the two terms. This could also be understood in regards of illiteracy and innumeracy in this country and the need for strong literacy education, as the need for professionals prepared to work in basic literacy is mostly embedded in formal learning environments.

\section{Conclusions and outlook}

This study revealed a lack of systematisation regarding the characteristics and functions associated with adult educators in three countries, confirming that the application of 'competence profiles and standards for adult learning staff $[\ldots]$ differs considerably between institutional and regional levels' (Buiskool, Broek, van Lakerveld, Zarifis, \& Osborne, 2010). The description of skill sets and characteristics that were found differed with regards to the prevailing circumstances in each country and regarding the tasks and challenges in each chosen field of action. Accordingly, the study identified standardised terminology in adult education, used exclusively within the borders of one specific profession or regarding a particular target group, such as India's orientation towards basic literate and numerical education, the dual education system in Germany, and the socio-cultural orientation of the Portuguese education system.

It is indicated that a trans-sectorally consistent usage of terminology, primarily regarding education and training, knowledge, competences, and the characteristics of adult educators (Cruess, Cruess, \& Steinert, 2016) is required. In order to facilitate a fruitful dialogue that will provide the background for professional identity-building, further discussion on the lack of shared definitions and the establishment of a consistent and defined adult education terminology is necessary. This is specifically true for India, as its discourse on adult education professionals takes place on a comparatively small scale. However, for all three countries it is suggested to consider existing orientation frameworks and implement these in future publications more frequently, specifically those definitions provided at the supranational level (Buiskool et al., 2010).

The study did not find direct indicators that an institutionally initiated examination or reflection on identity-building was conducted during the education and training of adult education professionals. The evaluated sources did not provide concrete terminological guidance, no active support for identity formation for adult educators, nor an impulse for reflection on identity, missing out on the 'most meaningful source of knowledge that professionals acquire' (Hansman, 
2016, p. 35). Identity formation and self-reflection in adult education professionals during their education and training can support adult educators in establishing a reflective self-image and professional identity so that they more actively choose and shape their individual career paths. Therefore, it is further suggested to raise awareness regarding the multifariousness of adult education, encourage reflection on professional identity, and facilitate the development of professional identity. In this way, adult educators can be encouraged to form and improve the field of adult education in a 'Biermian sense'.

\section{References}

Bechtel, Mark: "Kompetenzprofile für Erwachsenenbildner". DIE-Zeitschrift für Erwachsenenbildung (4), 2008, pp. 36-38, retrieved 13.05.2017 from: http:// www.diezeitschrift.de/42008/kompetenz-03.pdf.

Bierema, Laura L.: "Professional identity". In: Kasworm, Carol E. / Rose, Amy / Ross-Gordon, Jovita M. (eds.): Handbook of Adult and Continuing Education. Sage: Thousand Oaks, CA 2010, pp. 135-146.

Bierema, Laura L.: "Reflections on the profession and professionalisation of adult education”. PAACE Journal of Lifelong Learning (20), 2011, pp. 21-36, retrieved 13.05.2017 from: http://www.iup.edu/ace/paace/v20-2011/.

Bogdan, Robert / Biklen, Sari: Investigação Qualitativa em Educação. Uma Introdução à Teoria e aos Métodos. Porto: Porto Editora 1994.

Buiskool, Bert-Jan / Broek, Simon D. / van Lakerveld, Jaap A./ Zarifis, Georgios K. / Osborne, Michael: "Key competences for adult learning professionals. Contribution to the development of a reference framework of key competences for adult learning professionals". Andragoške Studije (2), 2010, pp. 185-187, retrieved 15.05.2017 from http://www.as.edu.rs/pdf/articles/70.Bundesinstitut für berufliche Bildung: Datenreport zum Berufsbildungsbericht 2014. Informationen und Analysen zur Entwicklung der beruflichen Bildung. Bertelsmann: Bielefeld 2014.

Canário, Rui: Educação de Adultos. Um Campo, uma Problemática. Educa: Lisboa 1999.

Carvalho, Adalberto / Baptista, Isabel: Educação Social. Fundamentos e Estratégias. Porto Editora: Porto 2004.

Cooper, Karyn / Olson, Margret R.: “The multiple 'I's' of teacher identity”. In: Kompf, Michael / Bond, W. Richard / Dworet, Don / Boak, R. Tewance. (eds.): Changing Research and Practice: Teachers' Professionalism, Identities and Knowledge. The Falmer Press: London/Washington, DC 1996, pp. 78-89. 
Cruess, Richard / Cruess, Sulvia R. / Steinert, Yvonne: "Amending Millers pyramid to include professional identity formation". Academic Medicine 91(2), 2016, pp. 180-185, retrieved 13.05.2017 from http://journals.lww.com/academic medicine/Fulltext/2016/02000/Amending_Miller_s_Pyramid_to_Include_ Professional.17.aspx

Egetenmeyer, Regina / Schüßler, Ingeborg: Akademische Professionalisierung in der Erwachsenenbildung/Weiterbildung. Schneider: Baltmannsweiler 2012.

Fragoso, António / Guimarães, Paula: "Is there still a place for social emancipation in public policies? Envisioning the future of adult education in Portugal". European Journal for Research on the Educational and Learning of Adults, 1, 2010, pp. 17-31.

Freire, Paulo: Pedagogía del Oprimido. Siglo XXI de España Editores: Madrid 1997.

Ghiglione, Rudolphe / Matalon, Benjamin: O inquérito: Teoria e Prática. Celta: Lisboa 1997.

Guimarães, Paula: "Ocupações da educação de adultos e desafios à profissionalisação: Tarefas e atividades desenvolvidas em contexto de trabalho". Revista de Estudos Curriculares 7(2), 2016, pp. 57-81.

Hansman, Catherine. A.: "Mentoring and Informal Learning as Continuing Professional Education". In: Coady, Maureen (ed.): Contexts, Practices and Challenges: Critical Insights from Continuing Professional Education. John Wiley \& Sons: Hoboken 2016, pp. 31-42.

Mishler, Elliot G.: Storylines: Craft Artists' Narratives of Identity. Harvard University Press: Cambridge 1999.

Morgan, David L.: "Focus groups". Annual Review of Sociology 22, 1996, pp. 129152.

Nittel, Dieter: Von der Mission zur Profession? Stand und Perspektiven der Verberuflichung der Erwachsenenbildung. W. Bertelsmann: Bielefeld 2000.

Nittel, Dieter: "Der Erwachsenenbildner". In: Fuhr, Thomas / Gonon, Philipp / Hof, Christiane: Erwachsenenbildung - Weiterbildung: Handbuch der Erziehungswissenschaft. $4^{\text {th }}$ edition. Schöningh: Paderborn 2011, pp. 487-504.

Pinto, Luis: Sobre educação não-formal. Cadernos d'inducar. 1-7. 2005. Cadernos D'Inducar

Rapold, Monika: Pädagogische Kompetenz, Identität und Professionalität. Schneider: Baltmannsweiler 2006.

Ricardo, Rute / Fragoso, António: "Working in the third sector. A case study based on the perceptions of educators from Southern Portugal". In: ESREA Network on Between Global and Local: Adult Learning and Development. Institute of Education, University of Lisbon: Lisbon 2014, pp. 166-174. 
Rothes, Luis A.: "A formação de educadores de adultos em Portugal. Trajetos e tendências". Fórum 34, 2003, pp. 35-62.

Salling Olesen, Henning: "Professional Identities, Subjectivity and Learning. Be(com)ing a General Practitioner". In: West, Linden / Alheit, Peter / Anderson, Anders S. / Merrill, Barbara (eds): Using Biographical and Life History Approaches in the Study of Adult and Lifelong Learning: Perspectives from Across Europe. Peter Lang: Frankfurt/M. et al. 2006, pp. 125-141.

Salling Olesen, Henning: Professional Identities as Learning Processes in Life Histories. Paper for the ESREA conference on Biography and Life History Research, Roskilde, 2001a.

Salling Olesen, Henning: "Professional identities as learning processes". Life Histories. Journal for Workplace Learning 13 (7-8), 2001b, pp 290-97.

Schütz, Julia: Pädagogische Berufsarbeit und Zufriedenheit. Eine bildungsbereichsübergreifende Studie. W. Bertelsmann: Bielefeld 2009.

Schwendenwein, Werner: "Profession - Professionalisierung - Professionelles Handeln”. In: Alisch, Lutz-Michael / Baumert, Jürgen / Beck, Klaus (eds..): Professionswissen und Professionalisierung. Technische Universität Braunschweig: Braunschweig 1990, pp. 359-381.

Shah, S.Y.: "Lifelong Learning in India: A Policy Perspective". In: ASEM Education and Research Hub for Lifelong Learning. Aarhus University: Aarhus 2017, retrieved 13.05.2017 from: http://asemlllhub.org/policy-briefs/lifelong-learningin-india-a-policy-perspective/.

Shah, S.Y.: "Mapping the field of training in adult and lifelong learning in India": In: Egetenmeyer, Regina / Nuissl, Ekkehard: Teachers and Trainers in Adult and Lifelong Learning. Asian and European Perspectives. Peter Lang Verlag: Frankfurt/M. et al. 2010, pp. 55-76

Shah, S.Y.:"Teaching and training in adult and lifelong learning in India: Need for professionalisation". Indian Journal of Adult Education 71(4), 2010, pp. 80-100, retrieved 13.05.2017 from: http://www.iaea-india.org/journal/oct-dec10/syshah.html.

UNESCO: 2nd Global Report on Adult Learning and Education. Rethinking Literacy. UNESCO ILL: Hamburg 2007. 
Regina Egetenmeyer and Monica Fedeli - 978-3-631-73704-0

Downloaded from PubFactory at 01/11/2019 10:08:46AM

via free access 


\title{
Gaia Gioli, Nicoletta Tomei, Ashok Kumar \& Sunita Sijwali ${ }^{1}$ The development of employability skills in higher education curricula: A transnational comparison
}

\begin{abstract}
After defining employability and employability models with the aim of creating a theoretical framework for the following juxtaposition, the paper presents the strategies and practices developed at a higher education level in Italy and India for supporting the development of employability skills in young adults enrolled in master's degree courses in education.
\end{abstract}

\section{Definition of employability and employability models}

Work and the future of work are very fascinating subjects that play a central role in our life and our life plans. Indeed, work not only represents a tool to secure financial and economic independence from the home family, it is also a means to become active citizens, to be included and play a role in civil society as individuals. Therefore, it is very important that higher education reflects the profound changes affecting the world of work when planning the curricula that will help educate the future workforce.

Universities must tune an increasing proportion of their activity into the needs of students whose employability is at stake, and towards the needs of society at large. (World Employment Confederation, 2015, p. 35)

But what do we mean by the future of work, and how does it affect young people's employability?

According to the World Economic Forum, the 'future of work' represents all the changes occurring in the world of work, in terms of work capabilities, contracts, organisation, and regulations due to economic and technological change.

1 The paper is the result of joint work on the index, ideas for the paper, abstract, and references. However, the sections'Definition of employability and employability models' and 'Conclusion' can be attributed to Gaia Gioli, 'The case study of Italy' to Nicoletta Tomei, 'Soft skills approach in India' to Ashok Kumar, and 'The Indian higher education system and the master's degree curricula in education' to Sunita Swajli. 
[...] many occupations will undergo a fundamental transformation. They will change the skill sets required in both old and new occupations in most industries and transform how and where people work, leading to new management and regulatory challenges. (World Economic Forum, 2016, n. p.)

But what are the skills needs of employers when hiring a graduate? We cannot answer this question without considering that employers look for applicants with two skill sets: hard skills and soft skills. Hard skills (or technical skills, disciplinespecific skills) can change according to the economic field and specific work area, whereas soft skills (or common skills) are generally considered transversal or common to many different fields and workplaces. Moreover, we should reflect on the fact that no single word could summarise the things employers seek in a graduate. Some authors refer to assets, achievements, or attributes, although none of these terms really capture the hard work that graduates do to acquire what employers want. As suggested by Harvey and Knight (2003, p. 6), '[i]t is important to see attribute development as a process of learning and to insist that attributes are not collected like stamps'. Other researchers tried to summarise the main attributes/ skills/assets as follows.

Harvey, Moon, and Geall (1997) stress the attention on willingness to learn, self-management skills, adaptability, communication skills, team-working and interpersonal skills.

Stephenson and Yorke (1998) stress oral communication, workload management, team working, managerial skills, problem analysis, critical analysis, group problem-solving, stress resistance, commitment, flexibility, dependability, imagination/creativity, and willingness to learn.

Brennan, Johnston, Little, Shah, and Woodley (2001) highlight the importance of the ability to work independently, under pressure, oral communication skills, accuracy, attention to details, time management, adaptability, team working, taking responsibility and decisions, planning co-ordinating and organising.

It is difficult to identify a specific set that is common at a global level, yet multiple studies in the last decades have tried to do so. Most of them answered the question by linking the concept and definition of soft skills to that of employability and higher education, seeing it as the place to train graduates for future life from an academic perspective.

The term 'employability' has been extensively investigated in the past six decades, starting with the Robbins report (1963), which identified employability as one of the main goals of higher education institutions. From that moment on, the term had great diffusion and success, as it is very flexible. For example, it can be re-read through the lens of the capability approach, the lifecycle approach (Günter 
\& Markowitsch, 2010), entrepreneurship (Hall, 1996), or it can be applied to the context of higher education (Yorke, 2006). As a pedagogically oriented category, it was investigated by pedagogues and experts, especially from the UK (the most important publications are those published by the Higher Education Academy and ESECT, for example: Harvey, Locke, \& Morey, 2002; Harvey \& Knight, 2003; Pegg, Waldock, Hendy-Isaac, \& Lawton, 2012; Knight \& Yorke, 2004; Yorke \& Knight, 2006), who linked the term to the preparation of the transition from study to work, thus with the concept of placement. In this way, the term has had far-reaching consequences on the higher education system at a global level. The aim has been to modify higher education (Yorke, 2006; Boffo, Del Gobbo, Gioli, \& Torlone, 2017) in order to meet the needs of the labour market and the individual. In a certain way, to reflect on employability is to reflect on the ability of higher education to create educational paths that can 'build' professionals, their knowledge, and skills.

In the context of higher education, two authors must be mentioned: Peter Knight and Mantz Yorke, who spread a new way of studying employability and curricula and skills. Indeed, they were the first researchers who read curricula as a tool for the acquisition of employability and employability skills suitable for the labour market.

What do we mean by employability? The definitions of employability can be organised in two main groups. The first one relates to the abilities of students to get, retain and develop these employability skills on a job after graduation (Hillage \& Pollard, 1998, p. 3). The second one defines employability as:

A set of [...] skills, understanding and personal attributes - that make graduates more likely to gain employment and be successful in their chosen occupations, which benefits themselves, the workforce and the economy. (Yorke \& Knight, 2006, p. 3)

From this definition, it is particularly clear how the professional success of graduates in terms of employment is linked with the curricular activities undertaken during the studies, and how learning is intertwined with knowledge and all the skills that the labour market in a given world region and economic sector is looking for today and will be looking for in the longer term. As a matter of fact, we can assume that this outlook reflects the idea that higher education pays attention to the full development of human beings, as individuals and as future workers, following the lifecycle approach. Indeed, the labour market, social and cultural norms, and the economic situation can deeply affect graduates' current and future employment (Harvey, Locke,\& Morey, 2002; Pegg et al., 2012, p. 7).

The difference between the two groups of definitions is clear. The first definition stresses the career choice that students make after graduation and the career they will choose. 
The second definition has been implemented in the last twenty years in the UK with the involvement of businesses and employers in the construction of professional profiles of graduates. This approach - that we could call much more realistic than the first one -is intertwined with the ability of developing all those 'assets' (skills, knowledge, and personal attributes, such as values) that can support employment. These can be better explained by many important employability models that consider skills the basis of employability.

One of these models is the graduate employability model (Fig. 1) developed by Harvey, Locke, and Morey (2002), which focuses on the link between internal and external factors, that is, all the opportunities offered by higher education and the labour market for the development of employability, such as extracurricular experiences that can foster the acquisition of employability attributes, self-promotional skills, and willingness to self-development through work experience. This model is based on the involvement of engagement, pedagogy, self-reflection, and articulation as leading categories. The soft skills that are considered most important in this model are: self-promotional skills, the willingness to develop employability attributes, and the ability to reflect on them.

Figure 1: Graduate employability model.

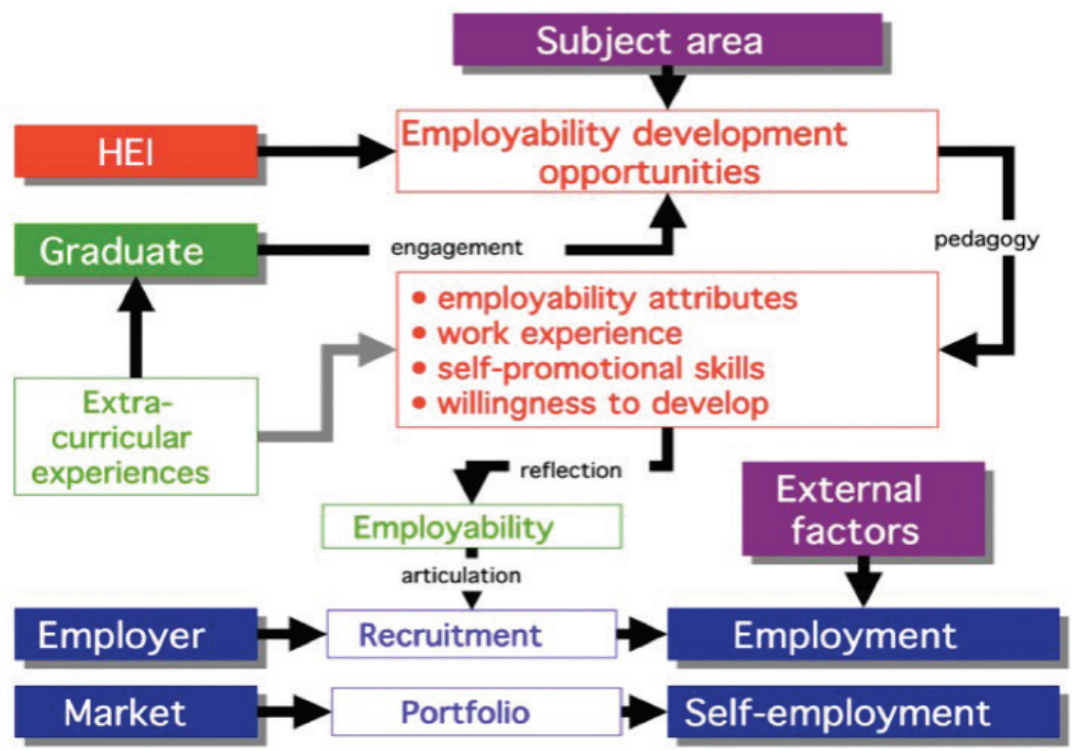

Source: Harvey, Locke,\& Morey (2002, p. 4) 
Shortly afterwards, the Higher Education Academy developed the USEM model (Fig. 2). In particular, the USEM model was developed by Knight and Yorke in 2004 and sees employability as the result of the interaction of 'four broad and inter-related elements': Understanding, Skilful practice, Efficacy beliefs, and Metacognition (Knight \& Yorke, 2004, p. 37).

Figure 2: USEM model.

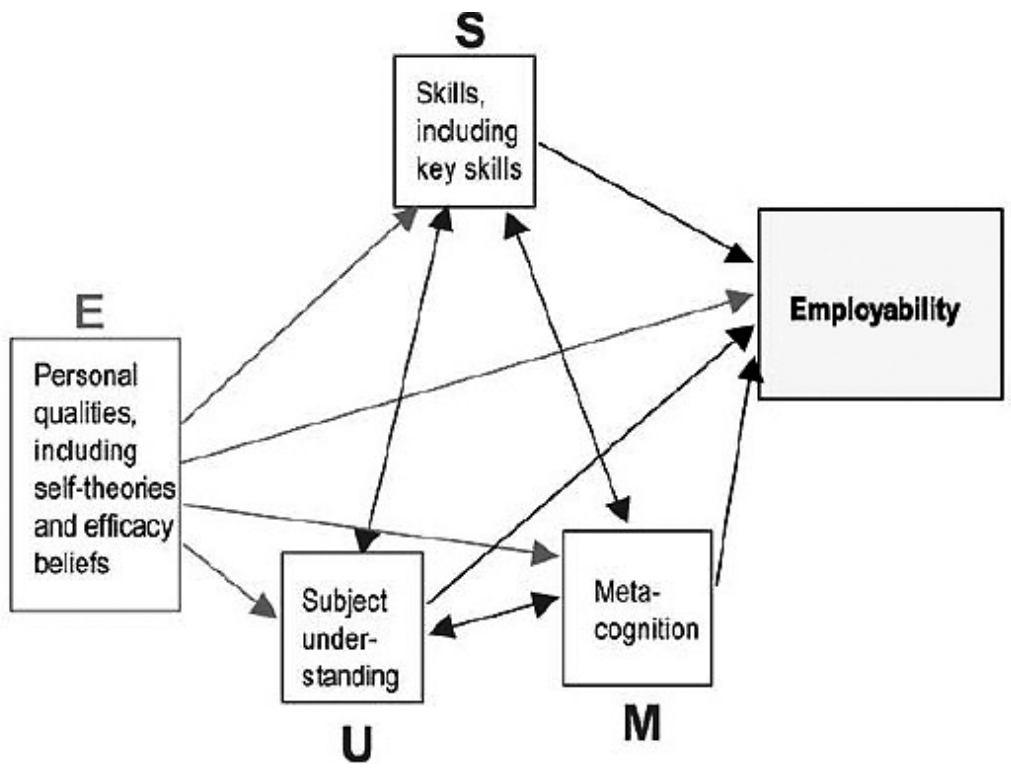

Source: Yorke \& Knight (2006, p. 4)

These categories are not only connected to the skills and knowledge that young people can acquire through curricular and extracurricular activities, they also represent the ability of academia to renew itself by offering students opportunities to develop self-reflectiveness and self-consciousness regarding their personal and professional identity, to develop a critical sense (metacognition), to acquire generic (skilful practice) and specific skills necessary for their future work and to be conscious of them (understanding), to guide themselves through life, and to learn how to learn and be able to read the contexts of life, situations, and events (efficacy beliefs) (Yorke \& Knight, 2006, p. 38).

The USEM model was created from empirical data to develop a commonly shared taxonomy in the scientific community. For this reason, it became the first famous employability model. Yet it was not the only one. Other important models 
are the DOTS model ${ }^{2}$ (Watts, 2006) and the CareerEDGE framework ${ }^{3}$ (Pool \& Sewell, 2007). The DOTS model stresses the attention on Self-awareness (the ability to identify and articulate motivations, skills, and personality as they affect career plans). Opportunity awareness (knowledge of opportunities and the ability to research these), Decision learning (being able to weigh personal factors to make a sound plan), and Transition skills (understanding of how to seek and secure opportunities) (Watts, 2006). The CareerEDGE framework stresses Career development learning, Experience (work and life), Degree subject, knowledge, understanding \& skills, Generic skills, and Emotional intelligence (Pool \& Sewell, 2007).

The conception of employability that underlies the above-mentioned models is very rich from a pedagogical perspective and can be thought of as the fundamental category to be used to rethink the structure of a study curriculum. Indeed, it is linked to a didactical approach and a renewal of higher education that sees all elements and persons working together towards the common goal of students' employability and the development of their skills.

According to Fallows and Steven (2000, p. 75), 'the academic curriculum is essentially a vehicle through which other attributes are delivered', and it includes information, discipline-specific, and generic skills. Generic (or soft) skills are different from discipline-specific skills because they can change according to the nature of the job and the specific workplace. Fallows and Steven also suggest that the modern workplace is so varied and constantly changing that academic education cannot hope to impact job-specific skills but should instead support the acquisition of soft skills and teach students how to learn new skills.

In the process, the institutional, organisational, and human dimensions of higher education should be involved. In the words of Knight and Yorke (2004, p. 269):

Program leaders and designers should be asking whether the approach to teaching and assessment is

- consistent with a rounded conception of employability;

- structured to encourage progressively higher levels of autonomy;

- appropriately balanced throughout the program (across contemporaneous units of study and across time);

- allowing those skills and qualities (that usually need longer than a study-unit to develop) the opportunity to grow progressively;

2 The DOTS model was developed by Professor A.G. Watts and represented the framework for the development of the UK higher education system (Law \& Watts 1977; Watts 2006).

3 The CareerEDGE model was introduced in 2007 as a framework for employability development targeted at academic staff, career staff, practitioners in employability activities, and students (Pool \& Sewell, 2007)

Regina Egetenmeyer and" Monica Fedeli - 978-3-631-73704-0 
- involving a variety of pedagogic methods and styles;

- encouraging deep rather than surface learning (or, put another way, weighting quality of learning more heavily than quantity of learning);

- valuing collaboration in learning for what it can offer to employability (but taking care to deal appropriately with assessment issues);

- providing plenty of feedback in a manner designed to enhance the capacity for self-assessment and to lead to enhanced future performance; and

- helping students to become aware of, and document (perhaps via portfolios), what they have achieved during their period of time in higher education.

Regardless the adopted model, employability is always interconnected with generic/soft and specific/hard skills. In particular, looking at the soft skills, we can affirm that they may change according to context. It may occur that the most relevant soft skills for the care and education professions are different in India and Italy because of the cultural, economic, social, and political context. Thus, it may happen that the adoption of an employability model could differ from one country to another. So, which are the recurrent employability skills embedded into the higher education curricula?

\section{The case study of Italy}

\section{Soft skills in Italy}

In Italy, the debate on soft skills has gained relevance in the wake of some international publications. Among them, the most important are Life Skills Education for Children and Adolescents in School, issued by the World Health Organisation (World Health Organisation, 1993), and the Recommendation on Key Competences for Lifelong Learning (European Commission, 2016).

At first, the recommendations contained in these documents were adopted by the school system, which in the 1990s started to set up training interventions on the basis of the concept of life skills. According to the above-mentioned WHO document, life skills are 'abilities for adaptive and positive behaviour that enable individuals to deal effectively with the demands and challenges of everyday life' (p. 1). These abilities play an important role in the broader category of psychosocial competence, which consists in the capacity to 'maintain a state of mental well-being and to demonstrate this [...] while interacting with others, his/her cultures and environments' (p. 1). The interventions inspired by this approach interpret life skills education as a tool for the promotion of physical, mental, and social health, which are able to influence behaviours in particular at a time when behaviours are more and more implicated as source of health problems' (p. 1). 
Life skills education developed acknowledging that prevention strategies based on control and repression of 'at risk' behaviours are a failure. Although it failed to integrate soft skills development into standard school activities, life skill education contributed to stimulating the implementation of projects able to develop skills which cross disciplinary fields and to expand the school curriculum.

After this first season of experimentation, the efforts for integrating soft skills into the school curriculum took advantages from the European Reference Framework presented by the above-mentioned recommendation of 18 December 2006. In fact, this recommendation, which identifies and defines the key competences necessary for personal fulfilment, active citizenship, social cohesion and employability in the knowledge society' (EPC 2006, p. 1 annex), determined the issue of Ministerial Decree n. 139 on 22 August 2007 by the Italian Ministry of Education, University and Research (Ministero dell'istruzione, dell'università e della ricerca (MIUR), 2007). This Decree, aiming to govern the field of mandatory education, states that the final diplomas of upper secondary school have to certify 'core competences related to language, STEM and history curriculum as well as specific citizenship skills which compose, together, the key competences for lifelong learning according to the Italian national strategies' (MIUR, 2007, p. 1 annex 1).

Table 1: Soft skills integrated into the Italian school curriculum as recommend by national and international documents.

\begin{tabular}{|l|l|l|}
\hline $\begin{array}{l}\text { Life Skills (WHO, } \\
\text { 1993) }\end{array}$ & Key Competences (EPC, 2006) & $\begin{array}{l}\text { Citizenship Skills (MIUR, } \\
\text { 2007) }\end{array}$ \\
\hline Problem-solving & $\begin{array}{l}\text { Communication in the mother } \\
\text { tongue }\end{array}$ & Learning to learn \\
\hline $\begin{array}{l}\text { Critical and } \\
\text { creative thinking }\end{array}$ & $\begin{array}{l}\text { Communication in foreign } \\
\text { languages }\end{array}$ & Projecting \\
\hline $\begin{array}{l}\text { Effective } \\
\text { communication }\end{array}$ & $\begin{array}{l}\text { Mathematical competence and } \\
\text { basic competences in science and } \\
\text { technology }\end{array}$ & Communicating \\
\hline Empathy & Digital competence & Collaborating and participating \\
\hline $\begin{array}{l}\text { Emotional } \\
\text { management }\end{array}$ & Learning to learn & $\begin{array}{l}\text { Autonomous and responsible } \\
\text { acting }\end{array}$ \\
\hline Stress management & Social and civic competences & Problem-solving \\
\hline Personal efficacy & $\begin{array}{l}\text { Sense of initiative and } \\
\text { entrepreneurship }\end{array}$ & $\begin{array}{l}\text { Linking and identifying } \\
\text { connections between concepts } \\
\text { and situations }\end{array}$ \\
\hline Social efficacy & Cultural awareness and expression & $\begin{array}{l}\text { Getting and interpreting } \\
\text { information }\end{array}$ \\
\hline
\end{tabular}

Source: Authors' own 
Besides the speculation on the certification of competences in the school system, the higher education sector has developed its own understanding of the acquisition of soft skills across tertiary study paths (Fondazione CRUI, 2016) This understanding is closely linked to the implementation of the Bologna Process. The term 'Bologna Process' refers to the international reform process through which European Union Member States try to harmonise national higher education systems in order to promote mobility through a better understanding and comparison of the different qualifications issued in each country (European Commission, 2016).

In 2005, this process of harmonisation, started in 1988 with the elaboration of the Magna Charta Universitatum, led to the adoption of the 'Qualifications Framework for the European Higher Education Area - QF for the EHEA' (Bologna Follow-up Group, 2005). This framework proposed to describe the qualifications issued for each cycle by each state, with reference to the number of ECTS credits and to the learning outcomes that characterise each qualification. In particular, the description of the learning outcomes of bachelor's and master's programmes was carried out using some shared descriptors. These descriptors, known as Dublin descriptors (named after the city in which they were finally defined), do not refer to any disciplinary field or professional area in particular and are built on the following elements:

- knowledge and understanding;

- applying knowledge and understanding;

- making judgements;

- communication skills;

- learning skills.

(Bologna Working Group on Qualifications Frameworks, 2005)

Soft skills in the curriculum of Italian master's programmes in adult and continuing education

According to the European procedure, and in consideration of the asset of the Italian higher education system after the university reform started in 1999, the Italian Qualification Framework, issued in 2010, states that, at the end of the second cycle of higher education, all students have to:

- demonstrate knowledge and understanding of their own study field by using advanced references, formulating hypotheses, and applying original ideas in a research context; 
- apply their knowledge and understanding to their own professional activities, conceptualizing and solving unfamiliar problems in disciplinary and interdisciplinary fields;

- collect, interpret, and integrate data and information by creating assessments which reflect social and ethical concerns linked to the application of their knowledge;

- communicate in a clear manner their conclusions and their underlying rationale to specialised and non-specialised audiences;

- develop their learning abilities in order to be able to continuously study in a self-directed and autonomous way.

(MIUR, 2011)

Beside describing the soft skills common to all master's programmes, the Dublin descriptors also provide the basis through which each university defines the learning outcomes that each student has to reach according to the professional profile focused by the programme he or she is attending. Regarding the master's programmes in adult and continuing education in Italy, the analysis of the official documents published on the ministerial web portal 'Universitaly' highlights some important information.

In the academic year 2016/17, eleven master's programmes in adult and continuing education were offered at the national level. They are evenly distributed across the country and, aside from local specifications, generally aim to develop professionals able to manage, plan, implement, and evaluate educational and training actions in the field of adult and continuing education and human resource management, including development and career guidance.

A deeper look into the contents of each programme shows that the curricula are composed of different kinds of courses, laboratories, extracurricular activities (in particular internships), and research activities mostly related to pedagogical, psychological and sociological knowledge. Courses in the humanities and technology make up the rest (Fig. 3).

The consistent weight given to courses in terms of ECTS points suggests that many of the soft skills linked to the specific professional profiles focused by the different master's programmes are being developed as part of the coursework. However, the analysis of the syllabus of different courses shows that only rarely are soft skills explicitly mentioned as expected learning outcomes. 
Figure 3: ECTS distribution in Italian master's programmes in adult and continuing education.

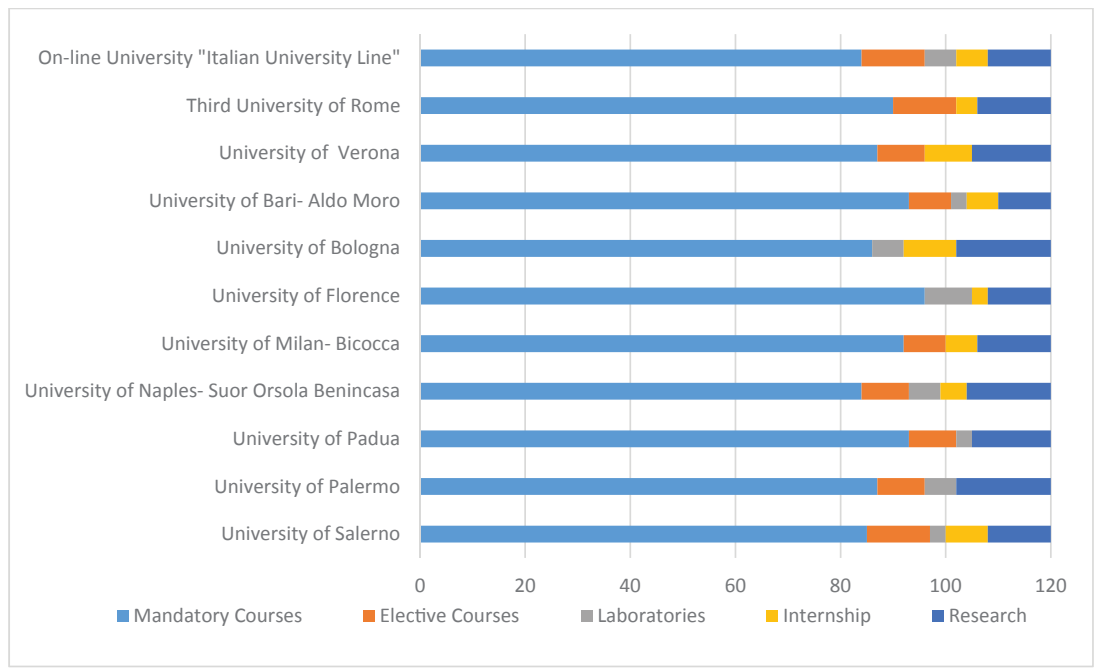

Source: Authors' compilation of Ministerial data from http://www.universitaly.it/index.php/cercacorsi/ universita

Including information about the goals of laboratories, internships, and research activities into the analysis confirms that soft skills are usually developed informally. Nevertheless, as stated by a recent publication, it is not uncommon to couple these informal ways of developing soft skills with reflective practices that help students to take advantage of experiential and work-related learning activities (Boffo, Fedeli, Lo Presti, Melacarne, \& Vianello, 2017).

To find examples of training activities that include soft skills as expected learning outcomes, it is more appropriate to consider the integrative training offers provided by guidance, tutoring, and placement services. Indeed, these services often seem to provide the opportunity to be trained for the development of the specific soft skills identified by partner institutions or by students themselves. In order to illustrate the mechanisms through which some of these services work, looking at the experience of the University of Florence could be very useful. The career service of this university has in fact promoted the establishment of a 'Light Assessment Centre' for the development of soft skills based on a survey which asked local human resources managers about the most relevant soft skills for the university graduates they are hiring (Boffo, 2018). 
Given the almost complete lack of explicit reference to soft skills in the institutional documents of the master's programmes in adult and continuing education, it is nearly impossible to guess which might be relevant for graduates' transitions into the labour market without referring to specific research projects.

In this perspective, the analysis performed in the framework of the international research project 'Skills and Labour Market to Raise Youth Employment' (Project Number: 527690-LLP-1-2012-1-PT-LEONARDO-LMP) can be helpful for identifying the essential soft skills that help adult education professionals find and keep a job in the context of the Italian social economy. Analysing materials gathered in the two years of research, the project states in fact that, even if 'the demand for professional profiles and workers' competences is conditioned by the basic functions performed by the organisation in question' (p. 98), the demand for transversal competences and soft skills corresponds to the necessity of combining technical skills with 1) personal qualities, 2) communication skills, and 3) interpersonal skills (p. 106) (see Table 2).

Table 2: The demand for soft skills for the future that emerged from the SALM research based on the Italian sample.

\begin{tabular}{|l|}
\hline \multicolumn{1}{|c|}{ 1. Personal qualities } \\
\hline Self-management \\
Self-control \\
Sense of responsibility \\
Adaptability \\
Initiative \\
Emergency management \\
Being patient \\
Strategic thinking \\
\hline \multicolumn{1}{|c|}{ Communication skills } \\
\hline Transmissibility \\
Expressivity \\
Empathy \\
Effective communication with external environment \\
\hline 3. Interpersonal skills \\
\hline Teamwork \\
Coaching \\
Personal development \\
Conflict management \\
Peer cooperation
\end{tabular}




\section{The case study of India}

\section{Soft skills approach in India}

A shortage of skills is one of the major constraints to continuous economic growth in India (International Labour Organisation, 2007). On the basis of these studies and observations, it has been found that in the sector of adult education, the concept of soft skills is neglected in India. Most of the government policies and documents emphasised the hard skills (NPSD, 2009), so it seemed that adult or youth employability is less affected due to the lower orientation towards soft skills and training in the sector of adult education.

It has been observed that in the Indian context, soft skills are considered only in the private sector or in multi-national companies such as BPOs, Deloite, and others. These multi-national companies effectively provide in-service training and pre-service training to their employees. Furthermore, it has also been observed on the basis of discussions with expert in adult education in India that, based on their observations, there is no need to provide training to adults because they have more experience and because of that experience, they can overcome all problems. Therefore, it has been found that if there were less training of soft skills, the result would be less employability in the sector of adult education in India (Indian policies, reviews).

Soft skills are 'people skills' consisting of personal attributes that drive an individual's potential for sustained growth and enhance their social interactions, job performance, and career prospects (Robbins \& Hunsaker, 1996).

Soft skills have been defined as 'the cluster of personality traits, social graces, language skills, friendliness, and optimism that mark each of us in varying degrees' (Career Opportunities News, 2002).

Fundamental soft skills are: self-awareness and self-esteem, critical thinking skills, decision-making skills, problem-solving skills, interpersonal skills, communication skills, empathy, coping with emotions, handling peer pressure, and negotiation skills (WHO, 1997).

The author personally observed that government documents and policies are focused on hard skills in the adult education sector, but it was also evident that the government makes the policy for adults only with regard to hard skills.

Based on field observations and interviews conducted with ten adult employees and with the various social workers, policy makers, and experts, it has been said that there is no need for adults to acquire soft skills because they already have sufficient knowledge and experience to deal with personal problems and they can easily communicate with colleagues. The government is making a very strong 
initiative promoting hard skills for adults in the organised and unorganised sectors, including Gender Resource Centres (GRCs) and Jan Shikshan Sansthans (JSSs). Even its new education policy, the government is not taking any initiative towards soft skills (National Policy on Education (NPE), 1986).

\section{Agencies of soft skills and role of higher education in this context}

After reviewing the official policies, we find that there is no formal criterion for soft skills training. Due to that, the higher education is not taking any initiative for soft skills, so employability in the sector of adult education is not up to the mark.

There are some organised and unorganised agencies providing hard skills to the sector of adult education, such as Gender Resource Centres (GRCs) and Jan Shikshan Sansthans (JSSs). These agencies provide hard skills such as tailoring, beautification, computer learning, documentation, and others.

\section{The Indian higher education system and master's degree curricula in education}

The term 'higher education' in India refers to post-secondary education $(10+2)$, beginning after 10 years of primary and secondary education and 2 years of senior secondary or tertiary-level education. Higher education degrees include bachelor's degrees, post-graduate degrees, and research degrees (M.Phil and PhD). Higher education in India holds a significant place in the country's educational process. Since independence, higher education has been regarded as one of the important tools for national development, as it has the important task of preparing leaders for different paths of life, such as social, intellectual, political, cultural, scientific and technological careers. It serves to understand life and to enlighten the people (Gandhi, 2013, p. 63).

The higher education system in India is experiencing a transition phase from a conventional education system, or teacher-centred mode of instruction, to a progressive education system that is more student-centred and employment-oriented (University Grants Commission, 2012).

Various initiatives and transformations have taken place, designed to keep pace with growing industry demands and the global positioning of the Indian economy. India is the single largest provider of global talent, with one in four graduates in the world being a product of the Indian system (Ernst\& Young, 2013, p. 8). The Indian education system focuses almost exclusively on technical knowledge while ignoring critical areas like industry exposure and soft skills development (Padhi, 2014, p. 3). As a matter of fact, the 'freshers' (those who do not have any work experience, or who have just finished their professional degrees) face career 
limitations due to their limited English language capabilities, weak communication skills, and poor interpersonal skills (Askari, 2010, p. 2).

Employability is a very crucial aspect of the higher education system. The need of the hour is to take serious consideration of the career paths to help students acquire the skills demanded by the labour market, such as analytical thinking skills, communication skills, presentation skills, teamwork skills, and IT skills (Public \& Social Policies Management Group \& YES Bank, 2014, p. 12). Various recommendations from the National Knowledge Commission Report also point out the lack of spoken and written English skills. English is the primary language of teaching and learning in all higher education courses in India, meaning that a lack of English skills becomes a serious obstacle to accessing resources and entering the job market (National Knowledge Commission Report to the Nation 2006-2009, p. 49). The Indian higher education system has gone through many reforms and transformations in order to raise the quality of education.

Higher education institutions across the globe are implementing a system of credits, including the European Credit Transfer System (ECTS) in Europe and the National Qualifications Framework in Australia.

The University Grants Commission (UGC), India's leading body in higher education, which is responsible for coordination, determination, and maintenance of standards and the release of grants, observed in 2014 that in spite of the large number of public and private educational institutions engaged in imparting education in India, the present education system produces young minds lacking knowledge, confidence, values, and skills. One reason might be the complete lack of relationships between education, employment, and skill development in he conventional education system (UGC, 2009).

The University Grants Commission argued that there is need to allow for more flexibility in the education system. Hence, with a view to quality in higher education, the University Grants Commission (UGC) in 2015 implemented the Choice Based Credit System (CBCS) for graduate/postgraduate diplomas and certificate programmes at the higher education level.

Choice Based Credit System means that students (undergraduate, postgraduate, diploma and certificate courses) have the option to choose from the prescribed courses, including core, elective, soft skill, or minor courses. Under this scheme, students can take courses of their choice, learn at their own pace, take additional courses, and acquire more than the required credits. This system facilitates student mobility across educational institutions inside and outside of India. Depending on their interests and aims, students can choose interdisciplinary, intra-disciplinary, and skill-based courses (especially soft skill-oriented courses). So the CBCS not 
only offers opportunities and avenues to learn core subjects but also to explore additional avenues of learning beyond the core subjects for individual holistic development (UGC, 2015, pp. 5-7). Holistic development enables individuals to acquire formal qualifications along with soft skills, contributing to their employability and employment.

The University Grants Commission has emphasised ability enhancement courses (AEC) in addition to core courses under the Choice Based Credit System. Under the CBCS system, the available courses in each semester in a particular discipline consist of core courses, elective courses, and ability enhancement courses:

1) Core courses are to be offered in every semester and are compulsory for students enrolled in a given study programme.

2) Elective courses are specialised or advanced or supportive to the discipline/ subject of study enhancing students' proficiency/skills.

3) Ability enhancement courses may be of two kinds: ability enhancement compulsory courses (AECC) and skill enhancement courses (SEC). AECC are courses based on content that leads to knowledge enhancement. These are mandatory for all disciplines, for example environmental science, English communication/MIL communication. SEC courses are value-based and/or skill-based and are aimed at providing hands-on-training, competencies, skills, and the like (UGC, 2015, p. 7).

For example, an undergraduate degree in humanities, social sciences, or commerce may be awarded if a student completes four core papers each in two disciplines of choice, two core papers each in English and MIL respectively, two AECC, a minimum of four SEC, two papers each from a list of discipline-specific elective papers based on the two disciplines of choice selected above, respectively, and two papers from the list of general electives papers. If a student from the mathematics stream is interested in acquiring public speaking skills, under the Choice Based Credit System he can enrol in a public speaking course from another discipline.

Hence, under this system, students have more scope to enhance their skills and more scope to take up projects and assignments and vocational training, including entrepreneurship. According to UGC guidelines, the new system shifts the focus from teacher-centric to learner-centric education. The emphasis is on studying/learning and not on teaching, with the learner being at the centre stage of all academic transactions. This system may help improve students' the job opportunities and enable potential employers to assess the performance of students on a scientific scale. 


\section{Conclusion}

The two case studies present a different approach to employability and soft skills in a changing labour market with effects on employment.

Moreover, it is clear that it is not possible to talk and reflect on employability from a scientific point of view without considering how curricula are designed and which soft skills should be included. Nonetheless, there are a lot of possibilities from which the 'ideal type' of curriculum emerges. They are:

- employability throughout the whole curriculum;

- employability in the core curriculum;

- work-based or work-related learning incorporated as one or more components within the curriculum;

- employability-related module(s) within the curriculum;

- work-based or work-related learning in parallel with the curriculum (Knight \& Yorke, 2004, p. 199).

The juxtaposition shows that a similar approach to employability and soft skills is possible when considering the aim of single modules and/or courses.

- Soft skills are the central point for promoting professionalisation in the educational field. In both countries, the attention to soft skills is very high because, as research has shown, the acquisition of soft skills, the construction of employability, and the transition to the labour market are deeply intertwined. At the same time, there are a lot of differences in the set of soft skills that are considered most important in the two countries. Indeed, different socio-economic contexts require different professional profiles and different skills, although neither Italy nor India can demonstrate that the identification of soft skills to be acquired as part of the curriculum is directly connected to or guided by the labour market. What higher education needs to do is to increase the number of modules and courses directly connected to the practice of students' future professions, as indicated clearly by the graduate employability model, USEM, and the CareerEDGE models (see above), where extracurricular activities and work-related activities are considered the best way to acquire soft skills.

- The approach to employability is quite similar. In both countries, we can observe that the curricula provide at least one module/course that adopts workbased or work-related didactical approach.

- Italian and Indian university curricula are quite different because their main structural elements are different. For example, we can find different contents, types of didactical approach, tools, and so on. In particular, no curricular 
practical training is included in Indian curricula, as if practical experience should take place separately from theoretical moments.

To conclude, we can affirm that juxtaposing curricula, soft skills, and employability approaches at the global level is very important, because these features are deeply intertwined with the internationalisation of higher education in the care and education field and the construction of a civil society based on the intercultural exchange of best practices and the development of a unified society. Moreover, studies in adult education are part of the foundation of every democratic society.

\section{References}

Askari, Faiz: Polish Your Soft Skills to Climb the Ladder of Success. 2010, pp. 1-4, retrieved 07/2017 from https://www.smallenterpriseindia.com/index.php/ knowledage-center/hr/199-polish-your-sft-skills-to-climb-the-ladder-ofsuccess.

Boffo, Vanna: Giovani Adulti tra Transizioni e Alta Formazione.Strategie per l'Employability. Dal Placement ai Career Services. Pacini Editore: Firenze 2018.

Boffo, Vanna / Fedeli, Monica / Lo Presti, Francesco / Melacarne, Claudio / Vianello, Michelangelo: Teaching and Learning for Employability.New Strategies in Higher Education. Pearson Italia: Milan-Turin 2017.

Boffo, Vanna / Del Gobbo, Giovanna / Gioli, Gaia / Torlone, Francesca: "Employability Processes and Transition Strategies in Higher Education. An EvidenceBased Research Study". In: Boffo, Vanna / Fedeli, Monica / Lo Presti, Francesco / Melacarne, Claudio / Vianello, Michelangelo: Teaching and Learning for Employability.New Strategies in Higher Education. Pearson Italia: Milan-Turin 2017, pp. 161-204.

Boffo, Vanna/Federighi, Paolo/ Torlone, Francesca: Educational Jobs: Youth and Employability in the Social Economy. Investigation in Italy, Malta, Portugal, Romania, Spain, United Kingdom. Firenze University Press: Florence 2015.

Bologna Follow-up Group: The European Higher Education Area. Achieving the Goals. Communique of the Conference of the European Ministers Responsible for Higher Education. Bergen, 19-20 May 2005, retrieved 04/2017 from https:// media.ehea.info/file/2005_Bergen/52/0/2005_Bergen_Communique_engl ish_580520.pdf.

Bologna Working Group on Qualifications Frameworks: A Framework for Qualifications of the European Higher Education Area.Ministry of Science, Technology and Innovation: Copenhagen 2005, retrieved 04/2017 from https://media.ehea. infofile/WG_Frameworks_qualification/71/0/050218_QF_EHEA_580710.pdf. 
Brennan, John / Johnston, Brenda / Little, Brenda / Shah, Tarla /Woodley, Alan: The Employment of UK Graduates.Comparisons with Europe and Japan. Higher Education Funding Council for England: Bristol 2001, retrieved 08/2017 from http://oro.open.ac.uk/328/.

Career Opportunities News: “'Soft skills'A key to employment today".Career Opportunities News20 (2), 2002, n. p.

Ernst and Young: Higher Education in India: Vision 2030 FICCI Higher Education Summit.2013, pp. 1-84, retrieved 06/2017 from http://www.ey.com/Publi cation/vwLUAssets/Higher-education-in-India-Vision-2030/\%24FILE/EYHigher-education-in-India-Vision-2030.pdf.

European Commission: Developing Future Skills in Higher Education. ET2020Peer Learning Activity (PLA). Brussels 25-26 February 2016. Key Findings. European Commission: Brussels 2016, retrieved 04/2017 from http://ec.europa. eu/education/sites/education/files/2016-future-skills-report_en.pdf.

European Parliament and Council of the European Union: "Recommendation of the European Parliament and of the Council of 18 December 2006 on key competences for lifelong learning". Official Journal of the European Union L 394/10, 30.12.2006, retrieved 04/2017 from http://eur-lex.europa.eu/legal-content/EN/ TXT/?uri=celex\%3A32006H0962.

Federighi, Paolo: Adult and Continuing Education in Europe. Using Public Policy to Secure a Growth in Skills. Publications Office of the European Union: Luxembourg 2013.

Fallows, Stephen / Steven, Christine:"Building employability skills into the higher education curriculum.A university-wide initiative".Education + Training42(2), 2000, pp. 75-83.

Fondazione CRUI: OU-I 2016 Report Osservatorio Università-Imprese. Osservatorio della fondazione CRUI per il dialogo e la cooperazione tra università e imprese, retrieved 07/2017 from http://www.educational.rai.it/materiali/pdf_ articoli/37421.pdf.

Gandhi, M. M.: "Vocationalisation of higher education. Key issues, options and strategies". International Journal of Innovative Research and Development 2(8), 2013, pp. 62-69.

Government of India: National Policy on Education 1986(NPE), Department of Education, Ministry of Human Resource Development, G.O.I., New Delhi 1986

Government of India: National Policy on Education (1986), Programme of Action (Draft), Ministry of Human Resource Development (Department of Education), G.O.I., New Delhi 1992. 
Günter, Hefler / Markowitsch, Jörg: "Formal adult learning and working in Europe. A new typology of participation patterns". Journal of Workplace Learning 22(1/2), 2010, pp. 79-93.

Harvey, Lee / Knight, Peter: Briefing on Employability 5. Helping Departments to Develop Employability. ESECT: York 2003, retrieved 06/2017 from http:// www.employability.ed.ac.uk/documents/Staff/HEABriefings/HEA-Briefing5Helping_depts_develop_employability.pdf.

Hall, Douglas T.: "Protean careers of the 21st century". The Academy of Management Executive 10(4), 1996, pp. 8-16.

Harvey, Lee / Locke, William / Morey, Alistair: Enhancing Employability, Recognising Diversity. Making Links Between Higher Education and the World of Work. Universities UK and CSU: London 2002, retrieved from https://www. qualityresearchinternational.com/Harvey\%20papers/Harvey,\%20Locke\%20 and\%20Morey\%202002\%20Enhancing\%20employability.pdf.

Harvey, Lee / Moon, Sue / Geall, Vicki: Graduates' Work: Organisation Change and Students' Attributes. Centre for Research into Quality and Association of Graduate Recruiters: Birmingham 1997.

Hillage, Kim / Pollard, Emma: Employability: Developing a Framework for Policy Analysis. DfEE: London 1998.

International Labour Organization: Governing Body GB.298/ESP/3, 298th Session, Portability of Skills. ILO: Geneva, March 2007, retrieved fromhttp://www.ilo. org/wcmsp5/groups/public/@ed_norm/@relconf/documents/meetingdocu ment/wcms_gb_298_esp_3_en.pdf.

International Labour Organization: Resolution on Skills for Improved Productivity, Employment Growth and Development. 97th Session the International Labour Conference. ILO: Geneva 2008.

Knight, Peter / Yorke, Mantz: Learning, Curriculum and Employability in Higher Education. Routledge Falmer: London 2004.

Law, Bill / Watts, A.G.: Schools. Careers and Community. A study of Some Approaches to Careers Education in Schools. Church Information Office: London 1977.

Ministero dell'istruzione, dell'università e della ricerca: Decreto ministeriale $n$. 139 del 22 agosto 2007 "Regolamento recante norme in materia di adempimento dell'obbligo di istruzione". Ministero dell' istruzione, dell'università e della ricerca: Rome 2007, retrieved 04/2017 from https://archivio.pubblica.istruzione.it/ normativa/2007/dm139_07.shtml.

Ministero dell'istruzione, dell'università e della ricerca: Il quadro dei titoli italiani. Qualifications framework for the Europea Higher Education Area. Ministero dell'istruzione, dell'università e della ricerca: Rome 2011, retrieved 
07/2017 from http://hubmiur.pubblica.istruzione.it/alfresco/d/d/workspace/ SpacesStore/3762c381-7c18-4c76-b09d-9d5f32d13456/QuadroTitoli.pdf.

Ministry of Human Resource Development: University and Higher Education 2016. MHRD: New Delhi 2016, retrieved 05/2017 from http://mhrd.gov.in/ university-and-higher-education.

Ministry of Labour and Employment: National Policy on Skill Development. MLE: New Delhi 2009, retrieved from www.labour.nic.in/upload/uploadfiles/files/ Policies/NationalSkillDevelopment Policy Mar09.pdf.

National Knowledge Commission: Report to the Nation. 2006-2009. National Knowledge Commission: New Delhi 2009,, retrieved 06/2017 fromhttp:// knowledgecommissionarchive.nic.in/downloads/report2009/eng/report09. pdf.

Padhi, Prasanta: "Soft skills: education beyond academics". IOSR Journal of Humanities and Social Science 19(5), 2014, pp. 1-3.

Pegg, Ann / Waldock, Jeff / Hendy-Isaac, Sonia / Lawton, Ruth: Pedagogy for Employability. The Higher Education Academy: York 2012.

Pool, Lorraine Dacre / Sewell, Peter: ,The key to employability: developing a practical model of graduate employability“. Education and Training 49 (4), 2007, pp. 277-289.

Public and Social Policies Management Group / YES Bank: Skill Development and Higher Education in India. YES Bank Mumbia, 2014, retrieved 07/2017 from https://www.yesbank.in/pdf/skill_devlopment_higher_education_in_india. pdf.

Robbins, Lord: Higher Education. Report of the Committee under the Chairmanship of Lord Robbins. Her Majesty's Stationery Office: London 1963.

Robbins, Stephen P. / Hunsaker, Phillip L.: Training in Interpersonal Skills: TIPS for Managing People At Work. 2nd ed. Prentice-Hall: Upper Saddle River 1996.

Stephenson, John / Yorke, Mantz: Capability and Quality in Higher Education. Kogan Page: London 1998.

University Grants Commission: Action Plan for Academic and Administrative Reforms. University Grants Commission: New Delhi 2009, pp. 1-12, retrieved 06/2017 from http://www.ugc.ac.in/pdfnews/9682768_Action_plan-new_01. pdf.

University Grants Commission: Higher Education in India At a Glance. University Grants Commission; New Delhi 2012,pp. 1-10, retrieved 05/2017 from http:// www.ugc.ac.in/ugcpdf/208844_heglance2012.pdf.

University Grants Commission: UGC Guidelines on Adoption of Choice Based Credit System. University Grants Commission: New Delhi 2014, pp. 1-6, retrieved 06/2017 from http://collegesat.du.ac.in/UGC_credit_Guidelines.pdf. 
University Grants Commission: Minimum Course Curriculum for Undergraduate Courses under Choice Based Credit System. University Grants Commission: New Delhi 2015, retrieved from http://www.ugc.ac.in/pdfnews/8023719_guidelinesfor-cbcs.pdf.

Watts, A.G.: Career Development Learning and Employability. The Higher Education Academy: York 2006, retrieved 07/2017 from http://citeseerx.ist.psu.edu/ viewdoc/download?doi=10.1.1.472.7741\&rep=rep1\&type=pdf.

World Economic Forum: Report The Future of Jobs. World Economic Forum: Geneva 2016, retrieved 04/2017 from http://reports.weforum.org/future-ofjobs-2016/.

World Employment Confederation: The Future of Work. White Paper from the University Grants Commission: Guidelines for CBCS. World Employment Confederation: Brussels 2015, pp. 1-27, retrieved 06/2017 from http://www. ugc.ac.in/pdfnews/8023719_gfuidelines-for-cbcs.pdf.

World Health Organisation: Life Skills Education for Children and Adolescents in School. World Health Organisation: Geneva, 1993.

World Health Organisation: Life Skills Education in Schools. WHO/MNH/ PSF/93.7A.Rev.2. WHO: Geneva 1997.

Yorke, Mantz: Employability in Higher Education. What It Is, What It Is Not. The Higher Education Academy: York 2006.

Yorke, Mantz / Knight, Peter: Embedding Employability into the Curriculum. ESECT and the Higher Education Academy: York 2006. 


\title{
Robert Jjuuko, Zahia Alhallak \& Concetta Tino \\ Learning and work: Efficacy of university internships for syrian and ugandan education students
}

\begin{abstract}
Internships and related strategies within the work-related learning umbrella are credited for bridging university education and the world of work. From a comparative perspective, this paper, based on an interview study, discusses the Syrian university internship model for students in teacher education and the Ugandan university internship model in adult and community education.
\end{abstract}

\section{Introduction}

Ongoing changes in society inevitably alter workplace requirements to the extent that even university graduates with the most job-specific qualifications need an orientation to match the demand. For decades, higher education has been under pressure from industry leaders to prepare work-ready graduates (Brown, Hesketh, \& Williams, 2003; EU Skills Panorama, 2014). In Uganda and Syria, there are renewed concerns over the quality of higher education and the increasing number of unemployed university graduates (El-Araby, 2011; Nuwagaba, 2012). As articulated by Moore and Morton (2017), the cost of poor work-readiness 'not only holds graduates back from gaining satisfactory employment, but also has an inhibiting effect on the performance of employing organisations, and ultimately the broader economy' (p. 592).

The study is a contribution to a better analysis of how universities attempt to bridge higher education and the world of work. It builds on the collective learning of a group of master's and doctoral students from five countries (Denmark, Portugal, Italy, Syria, and Uganda) who focused on work-related learning and teaching methods within the framework of the 2017 International Winter School on Comparative Studies in Adult Education and Lifelong (COMPALL) at the University of Würzburg.

The study explores and examines the efficacy of university internships for Syrian and Ugandan degree students in teacher education and in adult and community education, respectively. The main question is: 'How are university internship programmes at the two case-study universities organised, and how do they manage to promote the work-readiness of students?' The study, which focuses more on 
the process and less on the outcome or impact of internships, seeks to understand the experiences and perceptions of key stakeholders regarding the efficacy of internships in the two countries.

\section{Theoretical framework}

Tackling the education-to-work transition challenges of university students is a global topical issue with varied practical and theoretical dimensions for education and employment systems, policies and practices (Boffo, Federighi, \& Torlone, 2015). Therefore, the labour market increasingly challenges the curriculum and pedagogical autonomy of universities (Ayoubi, Al Zarif, \& Khalifa, 2017; European Commission, 2014; Boden \& Nedeva, 2010). Work readiness and employability, often used interchangeably, are the common concepts that communicate the demand for education and training to ensure that students are fit for the labour market (Harvey, 2003; WEF, 2014).

Besides job-specific technical competence, graduates are expected to possess specific skills, which are variedly labelled with terms ranging from soft, generic, transferable to social skills (Crebert, 2004; Hogan, Chamorro-Premuzic, \& Kaiser, 2013). These skills include intrapersonal and emotional intelligence, literacy and communication practices, good personal judgement, self-management, leadership, and lifelong learning tools (Bennet, 2002; Shoenfelt, Kottke, \& Stone, 2012). To ensure work-ready graduates, universities have had to rethink teaching and learning approaches (Yorke \& Knight, 2006), including the adoption of work-related learning methods among other options. The core of work-related learning pedagogy is the enhancement of the interconnectedness of learning and workplace realities (Frison, Fedeli, \& Taylor 2015).

Adult education as an academic discipline has embraced a pluralism of theories such as experiential learning, situated learning, and communities of practice, which feature the core tenets of participation and collaboration; and these, of course, are connected to work-related learning and internships in particular (Wenger, 1998). Internships as a prevalent work-related learning model offer students the opportunity to learn with and from the community of professionals (Lave \& Wenger, 1991; Mihail, 2006). Understood and designed in various ways, internships in the context of this discussion refer to mandatory work experiences or placements within a higher education curriculum framework but operating outside the direct routine authority of the university (Bullock, 2009). Besides, we acknowledge the range of university internship variants as defined by formats relating to timing, duration, location, credit-bound, and intern remuneration (Holdaway, Johnson, Ratsoy, \& Friesen, 1994). 
A selective review of the literature on mandatory university internships in a range of disciplines from medicine, nursing, law, hospitality, food, finance to education points to two interrelated themes: (i) mutual benefits to students, employers and universities, and by extension the interplay of their roles and that of state actors; (ii) conditions, opportunities, and challenges in enhancing the value, effectiveness, and impact of internships (Maskooki, Rama, \& Raghunandan, 1998; McNamara, 2009; Walmsley, Rhodri, \& Jameson, 2012; Shoenfelt et al., 2012). The literature points out the conditions that influence the efficacy of internship processes as well as the shortcomings associated with weak design and delivery approaches. These dimensions effectively bring into context two comparative categories, namely the role of actors and policy, which were part of the focus for the the comparative group work during the 2017 Würzburg Winter School on Comparative Studies in Adult Education and Lifelong Learning.

From the literature, we derive four parameters for constructing an internship quality framework, which also contains links to the efficacy dimensions informing the data collection tool we used in this study. The framework is helpful in designing an enabling environment for the three most important stakeholders (students, universities, and employers) to effectively fulfil their respective roles and responsibilities (Divine, Miller, Wilson, \& Linrud, 2008). First, is a strong university-industry partnership, which provides an enabling institutional arrangement to galvanise the interests and aspirations of students, universities, employers, and the industry in general (Feldmann, Folks, \& Turneley, 1999). The partnership is useful for enforcing rules and procedures for ensuring compliance with quality standards and agreedupon work and learning standards. Second, academic preparedness and relevance are core considerations, because they facilitate students' learning and adaptation to new professional realities at the workplace. Internship activities and tasks ought to be relevant to the academic discipline and within reasonable limits and breadth of students' competence. Workplace supervisors ought to guide interns through their zone of proximal development (Fernández, Guerrón-Quintana, Kuester, \& Rubio-Ramírez, 2015; Warford, 2011). Third, professional support and assessment provided by highly qualified university and workplace supervisors who understand the epistemologies of workplace learning are central. Valuable internships often embrace student's autonomy, collegial work relationships, social support, authentic learning opportunities, scaffolding, and mentorship. Assessment strategies need to be clarified and shared in order to inform the grading so as to offer meaningful guidance for students' career trajectory (Gault, Redington, \& Schlager, 2000). Fourth, ensuring prompt and adequate resources to meet the professional, logistical, and personal needs of students, university staff in charge of internships, 
and workplace supervisors is paramount. Time, space, and related facilities for workplace supervisors to effectively provide required guidance as well as all the pedagogical and logistical support for university supervisors combine to influence the quality of internship processes and outcomes (Holdaway et al., 1994).

\section{Study context}

Two case-study universities (Damascus University in Syria and Kyambogo University in Uganda) were selected to constitute the study focus and defining entities to identify and locate participants. Syria, a former French colony with about 21 million inhabitants by 2011, is one of the Middle East and North Africa countries with the highest youth unemployment rates in the world (European Training Foundation, 2012). The first university was established in 1920s, and until 2001, when the state adopted a neoliberal social economy to license private universities, higher education was state controlled and publicly financed (El Hassan, 2013). After obtaining a General Secondary Education (GSE) Certificate, students are eligible for a four- to five-year university degree course. Damascus University is the largest and oldest public university in the country; and it is not so much affected by the war conditions as the other universities in the country due to its location in the heart of the capital, which is relatively safe. The focus of this study is the internship programme by the Primary School Teacher Education Department in the Faculty of Education, which is a compulsory component of the four-year undergraduate degree in education. Officially referred to as practical education, it is designed for students to work in primary schools to get exposure to the school environment, the teaching process, and a real-world experience (Mutlak, 2010).

Uganda, a British colony until 1962 with about 35 million people according to the 2012 census, is one of the youngest countries in the world. The country's higher education journey started when the colonial government established a technical school in 1922, later transformed into a university in the 1960s (Tumuheki, 2017). Owing to its liberalisation policy, the Ugandan government opened up higher education provision to the private sector in the 1990s; by 2007, over 37 institutions of higher learning had been licensed. While the state retains its regulatory function, financing and delivery is largely private (National Council for Higher Education, 2007). Ugandan secondary students are eligible for a three- to five-year undergraduate degree course after obtaining a good Uganda Advanced School of Education Certificate. Kyambogo University is one of the seven state-controlled universities in the country, and it is organised in six faculties. Internships are increasingly becoming a common feature across all faculties. The three-year Bachelor of Adult and Community Education degree features a mandatory internship component. 


\section{Methodology}

This paper is based on data and information generated through a qualitative case study methodology that enabled internship supervisors, students, and graduates to narrate and describe their experiences and perceptions (Baxter \& Jack, 2008). The comparative perspective of the study was aimed at illuminating the forces and factors that define and influence the differences and similarities between the internship practices of the two universities (Bray, Adamson, \& Mason, 2014; Reischmann, 2011). A search and review of relevant macro- and meso-level documents was undertaken to gain insights into how the internships under study are being organised and managed (Table 1).

Table 1: List of secondary data sources.

\begin{tabular}{|l|l|l|}
\hline Type of document & Country & Title \\
\hline $\begin{array}{l}\text { Central Government } \\
\text { Statutory Instrument - } \\
\text { policy }\end{array}$ & Uganda & $\begin{array}{l}\text { Circular Standing Instruction No. 3 of 2011: } \\
\text { Internship placements in the Public Service }\end{array}$ \\
\hline $\begin{array}{l}\text { Central Government } \\
\text { Pronouncement - policy }\end{array}$ & Uganda & $\begin{array}{l}\text { Ministry of Education and Sports Ministerial } \\
\text { Policy Statement Financial Year 2017/2018, } \\
\text { presented to parliament for the budget debate }\end{array}$ \\
\hline University operational policy & Uganda & $\begin{array}{l}\text { Kyambogo University Strategic Plan } \\
\text { 2012/13-2022/23 }\end{array}$ \\
\hline University operational policy & Uganda & $\begin{array}{l}\text { Kyambogo University Guidelines on } \\
\text { Management of Kyambogo University } \\
\text { Examinations and Processing of Results }\end{array}$ \\
\hline $\begin{array}{l}\text { University guide for } \\
\text { workplace supervisors }\end{array}$ & Uganda & $\begin{array}{l}\text { Students field work assessment form for } \\
\text { agency/organisation supervisor }\end{array}$ \\
\hline University guide for students & $\begin{array}{l}\text { Uganda \& } \\
\text { Syria }\end{array}$ & $\begin{array}{l}\text { Fieldwork report form (UG) } \\
\text { Practical education report form (SY) }\end{array}$ \\
\hline $\begin{array}{l}\text { University guide for } \\
\text { university supervisors }\end{array}$ & $\begin{array}{l}\text { Uganda \& } \\
\text { Syria }\end{array}$ & $\begin{array}{l}\text { Supervision sheet (UG) } \\
\text { Practical education progress report form (SY) }\end{array}$ \\
\hline $\begin{array}{l}\text { University guide for } \\
\text { university supervisors }\end{array}$ & $\begin{array}{l}\text { Uganda } \\
\text { \& Syria }\end{array}$ & $\begin{array}{l}\text { How fieldwork is supervised (UG) } \\
\text { Assessment template (SY) }\end{array}$ \\
\hline
\end{tabular}

Source: Authors' own

A purposive sampling approach was used to achieve maximum variation in the selection of study participants (Coyne, 1997). 18 participants were selected in equal proportions from Uganda and Syria, as indicated in Table 2. As indicated 
in the table, the role of each category of participants has immense influence on the value and efficacy of internships.

Table 2: Research participants.

\begin{tabular}{|l|l|l|}
\hline $\begin{array}{l}\text { Category of actors: } \\
\text { 9 for each country }\end{array}$ & Sample & Reason \\
\hline $\begin{array}{l}\text { Workplace } \\
\text { internship } \\
\text { supervisors }\end{array}$ & 4 & $\begin{array}{l}\text { They are directly responsible for supporting and guiding } \\
\text { students during the internship placement period. } \\
\text { They possess first-hand perspectives on the students' } \\
\text { behaviour, performance, and learning practices. }\end{array}$ \\
\hline $\begin{array}{l}\text { University internship } \\
\text { supervisors }\end{array}$ & 4 & $\begin{array}{l}\text { They directly deal with students' internship needs and } \\
\text { requirements in line with the university internship } \\
\text { programme; their insights into the factors influencing } \\
\text { internship efficacy are crucial. }\end{array}$ \\
\hline $\begin{array}{l}\text { University internship } \\
\text { coordinators }\end{array}$ & 2 & $\begin{array}{l}\text { On behalf of the university and faculty, they play a } \\
\text { supervisory role in ensuring compliance with technical } \\
\text { and administrative procedures. Their perspectives on the } \\
\text { policy and governance implications for internships are } \\
\text { essential in fully understanding the practice. }\end{array}$ \\
\hline Current students & 4 & $\begin{array}{l}\text { Their fresh memories of their internship experience and } \\
\text { what they are going through at the university helps to } \\
\text { give the study a current perspective. }\end{array}$ \\
\hline Graduates & 4 & $\begin{array}{l}\text { Graduates reflections on their internship experience in } \\
\text { relation to current life and work realities are helpful in } \\
\text { examining the usefulness of internships. }\end{array}$ \\
\hline
\end{tabular}

Source: Authors' own

The participants were engaged, between March and April 2017, in standardised open-ended interviews that helped to yield in-depth and contextual evidence on the state of internship programmes at the two universities. The interview protocol had three sections: (i) basic data about the participant, (ii) internship in practice with eight questions, and (iii) personal view and reflections about the internship experience with four questions. 'Interviews enable participants to discuss their interpretations of the world in which they live, and to express how they regard situations from their own point of view.' (Cohen, Manion, \& Morrison, 2007, p. 349)

In Uganda, the main author, supported by a research assistant, conducted faceto-face interviews with the participants. Informed consent was sought beforehand, and all participants agreed to have sessions captured by handwriting and voice recorder. In Syria, the researcher used the WhatsApp voice-call platform to conduct interviews with six participants who had Internet access and transcribed 
the interviews. To reach the others, without Internet access, a research assistant who lives in Syria conducted face-to-face interviews with three participants, transcribed them, and sent them to the researcher.

Data organisation and analysis was undertaken within the generic qualitative data analysis framework and procedure. 18 transcripts were created, and rigorous coding was undertaken. Emerging codes were grouped into themes. The themes were further analysed and interpreted to describe the experiences and perceptions of stakeholders.

\section{Internships in education studies in Uganda and Syria}

Findings are organised and presented under eight headings, namely governance and management; aim, objectives, and benefits; financing; timing and duration; tasks and skills; supervision and support; assessment and grading; challenges. Case internships are from two contexts: a primary school teacher education degree course at Damascus University in Syria, and an adult and community education degree at Uganda’s Kyambogo University.

In Syria, primary schools are required by the Ministry of Education to provide internship placements for education students. In Uganda, students search for placements themselves in all sorts of government and non-government institutions. In both countries, the university writes a recommendation letter that the students use to apply for placements.

\section{Governance and management}

In both countries, there are related policies and rules, but they are not firmly mainstreamed and enforced, which impacts internship governance and management. In Uganda, the most significant high-level state policy on university internships, in recent times, is reflected in a ministerial statement to the parliament that 'for the inadequate opportunities for internships in public universities [...] it is partnering with Uganda Manufacturers Association to find placements for students [...] (Ministry of Education and Sports, 2017, p. 28). In its 10-year strategic plan ending in 2023, Kyambogo University plans to place students through memorandums of understanding with employers, but no substantive policy is in place to implement this strategy. In 2011, the government issued Standing Instruction No. 3 to regulate the collaboration between public service institutions and training institutions. None of the interviewed stakeholders expressed awareness of this policy.

University supervisors, students, and graduates mentioned some departmental guidelines relating to the daily routines of students and basic supervision tips. The 
one Ugandan university supervisor who said that there existed an explicit Faculty Industrial Training and Community School Practice Policy was contradicted by his colleagues who denied knowledge of such a policy framework. Indeed, no documentary evidence could be obtained apart from the supervision leaflets and forms issued by the department. In addition, workplace supervisors do not have a formal internship policy. Syrian students mentioned some rules relating to intern obligations and grading procedures by the supervisors. The university supervisors singled out the rules relating to their roles. Workplace supervisors presented modified extracts relating to the expected conduct of interns.

\section{Aim, objectives, and benefits}

Both Syrian and Ugandan university supervisors mentioned that the aim of internships is to enable students to do the practical tasks related to their future jobs and to obtain the required skills. They argued that the aim is to link theoretical knowledge with practical experience.

Current students and graduates shared similar views but added the benefits of minimising the anxiety associated with job market entry and of generating a positive attitude and self-confidence through exploring the work environment. Syrian workplace supervisors consider internship programmes a way to help the schools keep up with modern methods and benefit from young students' ideas and energy. They also consider it a duty and social responsibility. The Ugandan workplace supervisor talked about his organisations' new thinking about internships as a recruitment strategy. One of them said: 'Some interns have been retained in the teaching department; we have five teachers, in social work, I am one of them.'

\section{Financing}

In both Syria and Uganda, internship financing is a shared responsibility. The students and/or their sponsors meet the costs related to their transport to and from workplaces at host institutions. In both cases, universities pay for transport and related experiences to facilitate lecturers who are assigned to visit and supervise the students on internships. In Syria, internship placements are guaranteed free of charge by schools in accordance with the directive of the Ministry of Education. Teaching-learning materials for internships are provided by workplace institutions. University supervisors in both countries mentioned inadequate financing, which impacts the value and effectiveness of internship programmes. 


\section{Timing and duration}

In both countries, internships are organised after students have been exposed to the basics of their professions. In Syria, internships are undertaken in the second semester of the third year and in the first and second semesters of the fourth year, which translates into three to four weeks. Ugandan students take their ten-week internships in the second semester of the second and third years. The university supervisors explained that starting the internship in the second and subsequent academic years is appropriate, because students need to complete some courses and obtain the basic academic information related to concepts, theories, strategies, and methods.

\section{Tasks and skills}

In both cases, internship tasks are determined within the context of the routine operations of workplace institutions, and largely determined by the workplace supervisors. The role of university supervisors in this regard is apparently mute. The Syrian students and graduates mentioned lesson planning and teaching as the main internship tasks. Both workplace and university supervisors said that students undertake all the roles related to the teacher position in class and outside the class, including taking notes, observing, and taking charge of their work. Ugandan interns and supervisors mentioned more engagement in administrative tasks and generic duties than in discipline-based tasks. Students in both countries said that they developed a range of generic skills and attributes including self-confidence and communication skills.

\section{Supervision and support}

University supervision is mainly through support visits to interns by university supervisors. While interns are visited four times in a month in Syria, their Ugandan counterparts are visited once or twice during the entire internship period. Short sessions of not more than 30 minutes are held to provide feedback for Ugandan interns; their Syrian counterparts receive weekly sessions of 20-30 minutes in the first two semesters, while in the last third semester, they send a video recording of their school working hours to the university supervisors. Workplace supervisors support interns through the assignment of tasks and subsequent follow-ups, but within the framework of their work routines. Ugandan university supervisors mentioned using telephone and e-mails in providing support and guidance to their students. One of them mentioned the use of social media, including a WhatsApp group to stay in constant contact. 


\section{Assessment and grading}

In both cases, internship assessment results constitute part of the overall course grading and academic award, and university supervisors take the final decision on the final grade for students' internship performance. In Uganda, the university issues an assessment grid for both the university and workplace supervisors. In addition to the assessment of their daily and routine performance, students are required to write an internship report, which is assessed and graded; it constitutes $60 \%$ of the overall grade.

\section{Challenges}

Participants mentioned a number of challenges across the two countries. The relationship between universities and the host institutions is largely loose without firm institutional arrangements to enforce the required partnership. This has multiple effects on the quality of relationships between the interns, the supervisors, and entire work practices. In Syria, the student teachers are more or less visitors, because there is no real integration into the work environment. The Ugandan experience might be slightly better; it is only contextual and dependent on the discretional approach of workplace supervisors. In both countries, limited financial resources for supervision affect the regularity and quality of the guidance and feedback provided by both workplace and university supervisors.

Crowded workplaces due to the ever-increasing number of students seeking internships undermine the primary purpose of contributing to the development of students' work readiness. In Uganda, adult and community education students compete for internship placements with their counterparts from other social science disciplines. Syrian primary schools providing internship placements for Damascus University students are crowded with pupils, owing to the increasing number of internally displaced families from other cities and schools. Likewise, the increasing number of trainees who leave their universities to join Damascus University put extra weight and responsibilities on the schools and the university.

\section{Discussion}

This section deals with the socio-economic and political forces that influence internship practices in the two country case studies with a focus on two main categories for comparison: the role of actors and policy, as extrapolated around five aspects (i) weak management manifested by limited awareness of rules and regulations; (ii) inadequate financing; (iii) unbalanced relationship between university 
and internship host institutions; (iv) strength and intensity of supervision and support; and (v) academic relevance of internship activities and tasks.

The similarly limited awareness of the rules and regulations in both countries is not only caused by the endemic structural weakness of the state and its institutions - which can be ascribed to the diminishing coordination capacity and directive role of state institutions to ensure compliance with rules and regulations in Uganda, and to the long civil strife and violence in Syria - but is also determined at the micro level. Supervisors, in fact, in a perceived laissez-faire dimension, choose how to implement the internship programme, how to provide guidance and feedback to students, and how to realise the aim of current education.

A second similarity in both countries is the inadequate funding of internships even if final internship assessment results are a mandatory requirement in the overall grading and academic award across both cases. The common cause at the macro level was underlined by participants; namely, the diminished role of the state in financing university education amidst the liberalisation and massification of higher education. These budget cuts seem to mirror a political idea of privatisation, which does not consider revamping the higher education system to be one of the state's main objectives.

Stronger supervision and monitoring in Syria as compared to Uganda is attributable to the institutional framework of the Syrian Ministry of Education with its controlling influence on primary schools. In contrast to the adult and community education course, which is not assigned to any specific ministry without such an infrastructure, enforcement of a similar policy is not tenable. Student teachers' engagement in relevant academic activities and tasks during the internship period at primary school is in sharp contrast with student adult educators in Uganda, whose diverse disciplinary background and lack of a strong home ministry lead to engagement in largely generic community mobilisation tasks. These differences are determined by choices at the macro level, because it seems that the two countries have different aims: the centralisation of the education system in Syria and a possible orientation towards privatisation or the autonomy of higher institutions.

The dominant role of universities versus the weak role of host institutions on matters relating to internship design, including assessment and grading in both cases, is attributable to the long tradition giving universities unrivalled authority in determining who passes examinations and who does not. In Syria, where the university works with primary schools, the asymmetrical relationship between the two categories of actors cannot allow for equal responsibility and authority. In Uganda, workplace supervisors and their institutions offer internship placements just as a gesture of goodwill, but without strong awareness of the importance to 
create a strong partnership for quality internship experiences. Moreover, as mentioned earlier, the universities' weak institutional framework regarding internships in both countries is a reflection of poor governance and leadership that characterise public higher university education. Internship management and programmes do not have enforceable quality assurance parameters. The universities' dominance further points to a legacy of separate worlds of education and work, which again is a result of a deficiency in the policies at macro, meso, and micro levels.

\section{Conclusion and recommendations}

The required enabling environment for internships to effectively contribute to students' work readiness for the primary education sector in Syria and the adult and community education field of practice in Uganda is at variance with ideal conditions, particularly in regard to governance, resources, and optimum universityindustry relationships. Amidst the prevailing conditions, stakeholders expressed trust and conviction regarding the value and usefulness of internships in supporting the transition of young adults from university into their profession and work life. In unison, students and graduates affirmed that internships are important for their career growth and development.

On the overall, the efficacy of the case-study university internships, as judged from the perspectives of our framework of four parameters, is highly questionable. Besides, there are great possibilities for increased effectiveness and usefulness of internships once deliberate efforts are taken to design internships with clear quality indicators and outcomes. The study findings and reviewed literature corroborate this finding in their emphasis on the core aspects of: strong universityindustry partnerships; academic preparedness and relevance; professional support and assessment; and prompt and adequate resources. Traditional adult learning epistemologies and principles including participation, cooperation, and partnership (as included by several theoretical frameworks such as situated learning, communities of practice, and experiential learning) need to inform the university internship architecture much as they are located in a 'school education regime'.

Tackling the internal challenges of education systems can always yield tangible results once external structural forces are equally resolved. Uganda's private-sectorled economy and a liberalised education model characterised by a laissez-faire internship regime need a competent state to claim some degree of an interventionist character to facilitate university-industry partnerships. In addition to dealing with inherent political, cultural, and economic structural limitations like those in Uganda, Syria needs a stable government for education and employment systems to effectively support young adults in translating their skills into life and working 
contexts. Internships can effectively help students of both countries to develop the much-needed soft skills for their occupation and social mobility in schools and communities as well as in the larger employment contexts.

\section{References}

Ayoubi, Ram / Al Zarif, Kahla / Khalifa, Bayan: "The employability skills of business graduates in Syria. Do policy makers and employers speak the same language?" Education and Training 59(1), 2017, pp. 61-75.

Akeel, Adeeb / Shahin, Izat: The Relationship Between Higher Education Output and the Private Sector in Syria. University of Damascus: Damascus 2001, retrieved 20.03.2017 from http://www.esyria.sy/edamascus/index.php?p=storie s\&category=ideas\&filename $=201201191450011$.

Almutlak, Farah:"Practical training program for education students in Damascus University”. Damascus University Journal 26(1+2), 2010, pp. 61-96.

Amer, Waleed / Musa, Nairmeen: "Educational investment in human capital and its match to the requirements of the labour market in Syria". Journal for Research and Scientific Studies Economic and Legal Science 73 (1), 2015, pp. 219-237.

Baxter, Pamela / Jack, Susan: "Qualitative case study methodology. Study design and implementation for novice researchers". The Qualitative Report 13(4), 2008, p. 544.

Bennett, Roger: "Employers' demands for personal transferable skills in graduates. A content analysis of 1000 job advertisements and an associated empirical study". Journal of Vocational Education \& Training 54(4), 2002, pp. 457-476.

Boden, Rebecca / Nedeva, Maria: "Employing discourse. Universities and graduate 'employability”'. Journal of Education Policy 25(1), 2010, pp. 37-54.

Boffo, Vanna / Federighi, Paolo / Torlone, Francesca (eds.): Educational Jobs: Youth and Employability in the Social Economy Investigations in Italy, Malta, Portugal, Romania, Spain, United Kingdom. Vol.2. Firenze University Press: Firenze 2015.

Bray, Mark / Adamson, Bob / Mason, Mark: Different Models, Different Emphases, Different Insights. In Comparative Education Research. Springer: Comparative Education Research Centre, University of Hong Kong and Dordrecht, Hong Kong 2014, pp. 417-436.

Brown, Philip / Hesketh, Anthony / Williams, Sara: "Employability in a knowledgedriven economy." Journal of Education and Work 16(2), 2003, pp. 107-126.

Bullock, Kate / Gould, Virginia / Hejmadi, Momna / Lock, Gary: "Work placement experience: Should I stay or should I go?" Higher Education Research \& Development 28(5), 2009, pp. 481-494. 
Calvin, Smith: "Evaluating the quality of work-integrated learning curricula. A comprehensive framework". Higher Education Research \& Development 31(2), 2012, pp. 247-262.

Cohen, Louis / Manion, Lawrence / Morrison, Keith: Research Methods in Education. 6th edition. Routledge: London 2007, pp. 461-474.

Coyne, Imelda: "Sampling in qualitative research. Purposeful and theoretical sampling; merging or clear boundaries?" Journal of Advanced Nursing 26(3), 1997, pp. 623-630.

Crebert, Gay / Bates, Merrelyn / Bell, Barry / Patrick, Carol-Joy / Cragnolini, Vanda: "Developing generic skills at university, during work placement and in employment. Graduates' perceptions”. Higher Education Research \& Development 23(2), 2004, pp. 147-165.

Divine, Richard / Miller, Robert / Wilson, Holton / Linrud, Joann: "Key philosophical decisions to consider when designing an internship program". Journal of Management and Marketing Research 2(1), 2008, pp. 1-8.

El-Araby, Ashraf: "A comparative assessment of higher education financing in six Arab countries". UNESCO IBE Prospects (41), 2011, pp. 9-21.

EU Skills Panorama. Employability and Skills of Higher Education Graduates. icF GhK and cedefop for the European commission, 2014.

European Commission / EACEA / Eurydice. Modernisation of Higher Education in Europe. Access, Retention and Employability 2014. Eurydice Report. Luxembourg: Publications Office of the European Union 2014.

European Training Foundation: Transition from Education to Work in Syria. Results of the Youth Transition Survey 2009. European Training Foundation: Turin 2012, pp. 1-64, retrieved 03.04.2017, from https://goo.gl/AB9SPw.

Feldmann, Daniel C. / Folks, William R. / Turneley, William H.: "Mentor-protégé diversity and its impact on international internship experiences". Journal of Organizational Behavior, 1999, pp. 597-611.

Fernández-Villaverde, Jess. / Guerrón-Quintana, P. / Kuester, K. / Rubio-Ramírez, J.: "Fiscal volatility shocks and economic activity". The American Economic Review 105(11), 2015, pp. 3352-3384.

Frison, Daniela / Fedeli, Monica / Taylor, W. Edward: Work-Related Learning. A Survey on Teaching and Learning Methods in the Italian Higher Education System. ICERI 2015 Proceedings, pp. 8393-8401.

Frison, Daniela / Tino, Concetta/ Tyner, Jonathan W. / Fedeli, Monica: "Work-related teaching and learning methods to foster generic skills in higher education. An Italian experience". Tuning Journal for Higher Education 4(1), 2016, p. 14.

El Hassan, Karma: "Quality assurance in higher education in 20 MENA economies". Higher Education Management and Policy 24 (2), 2013, pp. 73-84. 
Gault, Jack/ Redington, John / Schlager, Tammy: "Undergraduate business internships and career success. Are they related?" Journal of Marketing Education 22(1), 2000, pp. 45-53.

Harvey, Lee: Transitions from Higher Education to Work. A briefing paper prepared by Lee Harvey (Centre for Research and Evaluation, Sheffield Hallam University), with advice from ESECT and LTSN Generic Centre colleagues. Sheffield Hallum University, 2003.

Holdaway, Edward / Johnson, Neil / Ratsoy, Eugene / Friesen, David: "The value of an internship program for beginning teachers". Educational Evaluation and Policy Analysis 16(2), 1994, pp. 205-221.

Hogan, Robert / Chamorro-Premuzic, Tomas / Kaiser, Robert B.: "Employability and career success. Bridging the gap between theory and reality". Industrial Organisational Psychology (6), 2013, pp. 3-16.

Night, Peter T. / Mantz, Yorke: "Employability and good learning in higher education". Teaching in Higher Education 8(1), 2003, pp. 3-16.

Lave, Jean / Wenger, Etienne: Situated Learning. Legitimate Peripheral Participation. Cambridge University Press: Cambridge 1991.

Lwamafa: Circular Standing Instruction No.3 Ministry of Public Service: Internship Placements in the Public Service. Government of Uganda: Kampala 2011.

Manual, Fernández / Rupert, Wegerif / Neil, Mercer / Sylvia, Rojas-Drummond: "Re-conceptualizing scaffolding and the zone of proximal development in the context of symmetrical collaborative learning". The Journal of Classroom Interaction 50(1), 2015, p. 54, retrieved 25.04.2017 from http://search.proquest. com/docview/1773927973.

Maskooki, Kooros / Rama, Dasaratha / Raghunandan, K: "Internships in undergraduate finance programs". Financial Practice and Education (8), 1998, pp. 74-82.

McNamara, Judith: Internships. Effective Work Integrated Learning for Law Students. Asia-Pacific Journal of Cooperative Education 10(3), 2009, pp. 229-240.

Mihail, Dimitrios M.: "Internships at Greek universities: An exploratory study". Journal of Workplace Learning 18(1), 2006, pp. 28-41.

Ministry of Education and Sports: Ministerial Policy Statement Financial Year 2017/2018: Presented to Parliament for the Budget Debate \& nbsp. Government of Uganda: Kampala 2017.

Moore, Tim / Janne, Morton: "The myth of job readiness? Written communication, employability, and the 'skills gap' in higher education". Studies in Higher Education 42(3), 2017, pp. 591-609. 
Mualla, Wael: Higher Education in Syria. University of Damascus: Damascus 2003, retrieved 06.05.2017 from http://damasuniv.edu.sy/qa/images/stories/ higher\%20education\%20in\%20syria.pdf.

National Council for Higher Education. The State of Higher Education and Training in Uganda 2006: A Report on Higher Education Delivery and Institutions. National Council for Higher Education: Kampala 2007.

Nuwagaba, Augustus: “Towards addressing skills development and employment crisis in Uganda: \&nbsp; the role of the public private partnerships". Eastern Africa Social Science Research 28(1), 2012, pp. 91-116.

Reischmann, Jost: Comparative Adult Education 2008. Experiences and Examples. A Publication of the International Society for Comparative Adult Education ISCAE. Peter Lang: Frankfurt a.M. et al. 2011, retrieved from http://replace-me/ ebraryid $=10601430$.

Silva, Patricia / Lopes, Betina / Costa, Marco / Seabra, Dina / Melo, Ana / Brito, Elisabeth / Dias, Gonçalo: "Stairway to employment? Internships in higher education”. Higher Education 72(6), 2016, pp. 703-721, retrieved from doi: 10.1007/ s10734-015-9903-9.

Shoenfelt, Elizabeth / Kottke, Janet / Stone, Nancy: "Master's and undergraduate industrial / organizational internships. Data-based recommendations for successful experiences". Teaching of Psychology 39(2), 2012, pp. 100-106.

Tovey, Janice: "Building connections between industry and university. Implementing an internship program at a regional university". Technical Communication Quarterly 10(2), 2001, pp. 225-239.

Tumuheki, Buhwamatsiko P.: Lifelong Learning in Practice. Understanding and Enabling Meaningful Participation of Non-traditional Students in University Education in Uganda. University of Groningen: Groningen 2017.

UNESCO: Bridging Learning for Youth. UNESCO Regional Education Response Strategy for the Syria Crisis. UNESCO: Paris 2016, retrieved 20.04.2017 from http://unesdoc.unesco.org/images/0024/002443/244333e.pdf.

Walmsley, Andreas / Rhodri, Thomas / Jameson, Stephanie: "Internships in SMEs and career intentions". Journal of Education and Work 25(2), 2012, pp. 185-204.

Warford, Mark K: “The zone of proximal teacher development". Teaching and Teacher Education 27(2), 2011, pp. 252-258.

Wenger, Etienne: Communities of Practice. Learning, Meaning, and Identity. First paperback edition. Cambridge University Press: Cambridge 1998.

Weible, Rich: "Are universities reaping the available benefits internship programs offer?" Journal of Education for Business (85), 2010, pp. 59-63. 
World Economic Forum: Matching Skills and Labour Market Needs. Building Social Partnerships for Better Skills and Better Jobs. World Economic Foraum: Geneva 2014.

Yorke, Mantz / Knight, Peter (eds.): Embedding Employability into the Curriculum. The Hihger Education Academy: York 2006. 
Regina Egetenmeyer and Monica Fedeli - 978-3-631-73704-0

Downloaded from PubFactory at 01/11/2019 10:08:46AM

via free access 


\title{
Bolanle C. Simeon-Fayomi, Elizabeth A. Ajayi, Nikola Koruga \& Geetanjali Baswani
}

\section{Enhancing employability through innovative teaching methods in adult learning and education: A comparative study of Nigeria and India}

\begin{abstract}
The study is based on the theory of andragogy, reviewing the practice and teaching methods of adult education in Nigeria and India with life stories from ten adults. The study arrived at a framework of innovative teaching methods that can be used in formal, non-formal and informal contexts to aid employability based on its findings.
\end{abstract}

\section{Introduction}

In today's globalised world, we are familiar with the concept of the knowledgebased society, in which education and work are interconnected. If we accept the idea that education should provoke positive change at the individual and society level, then adult learning and education (ALE) would be fundamental in societies experiencing dynamic economic changes, such as developing countries. This was confirmed in the Third Global Report on Adult Learning and Education, which emphasised the fact that education boosts skills that invariably make people successful and flexible in the labour market (UIL, 2016, p. 12). In the recent debate, employability is not only seen as prosperity but also as an effect of individual learning taking place in formal, non-formal, and informal settings as part of a lifelong learning process. Learners are empowered and enhanced by developing critical, reflective abilities. By developing these attributes, techniques, or experiences, employability enables learners to get jobs or to progress within the same career or to have a career transition. Employability is a main concern and issue for developing countries, because being enrolled in a professional course or formal education does not assure employability.

In recent years, we can track the changes happening in higher education to the idea of students' employability - especially in countries with a developed neoliberal economy, where the major role of tertiary institutions is the production of an appropriately trained workforce that fits employers' needs (Boden \& 
Nedeva, 2010, p. 38). Although building knowledge societies in terms of competitive economies places higher demands on individuals' educational level, there is a need for considering wider educational and cultural horizons, especially when analysing countries in economic transition or development.

Although developing countries struggle with and focus on illiteracy, ALE can be seen as a main factor for economic development, providing skills relevant to employment. This is important because employability means much more than getting a job. It is related to lifelong learning (LL), because individuals need a range of attributes, knowledge, skills, values, and social networks to gain and maintain employment throughout their lifetime. This perspective of employability shows that education should go beyond the formal school age and extend to adulthood. Moreover, it is important to keep in mind the broader view of education, which includes indigenous knowledge and authentic local experience in learning processes between teachers and adult learners. This is the aim of ALE: to develop active citizenship, to enable productive ageing, and to promote employability.

Through adult education issues of employability concerning young adults, middle-aged adults, and older adults can be addressed. The method of teaching to bring this about is very important, because it determines the extent to which the aims and objectives of learning are achieved (Bakare, 2010,p. 147). This makes it essential that ALE for employability adopts a teaching method that involves active participation and utilisation of adult learners' knowledge. This can be found in andragogy theory, which is a process model wherein a set of assumptions is identified to ensure the involvement of adult learners in the teaching and learning process (Knowles, Holton, \& Swanson, 2005, p. 115). Based on this, this study presents a comparative analysis of Nigeria and India with the specific purpose of providing answers to the following research questions:

1. What is the employment status and ALE practice in the two countries?

2. Which traditional ALE teaching methods are used in the two countries?

3. Which innovative ALE teaching methods can be used in the two countries to promote employability?

\section{Theoretical framework}

Using the tenets of andragogy, it can be inferred that learning provided by ALE must be experiential, drawing on the knowledge and characteristics of adult learners (Bakare, 2010, p. 131). Andragogy assumes that a teaching method ideal for employability must be one that helps adults understand that skills have a human relationship which must be learned at home, in school, or in social or formal 
groups. To ensure the acquisition of employability skills in adulthood and in any learning context, a teaching method should

1. encourage learning inquisitiveness;

2. encourage and move learners toward independence and self-directed learning;

3. ensure learners identify themselves as rich resources for learning;

4. revolve around real-world application of learners;

5. enhance performance in learners' lives through learning forums;

6. encourage and motivate adults to continually seek to update their knowledge and skills.

Teaching methods that fit into the above tenets can be regarded as innovative, because they will be within learner's social settings, make use of community wisdom, knowledge, and experiences; and train adults in both hard skills and soft skills, which are qualities of a good ALE teaching method (Okenimkpe, 2003, pp. 176-177).

\section{Teaching in ALE and employability}

In simple terms, a teaching method can be defined as the overall plan for systematic presentation based on an approach including specific activities known as techniques (Brown, 2001, p. 34). In ALE, the teaching method to be used should be one that goes beyond giving knowledge to empowering learners to be self-dependent in their learning activities. This is the difference between the conventional act of teaching children and the act of teaching adults. The teaching of adults includes the development of social and professional skills, which can be provided by ALE as a solution to formal education deficiencies. ALE contributes to the developmental needs of developing countries (Wadhwa, 2000, pp. 41-45).

ALE can also be regarded as multidimensional education aimed at providing knowledge and imparting skills in an integrated manner. It is based on the underlying idea that the needs of workers require specifically tailored programmes relating to employable skills (Jha, Goswami, \& Surana, 2015, p. 26). ALE as an aspect of LL helps to equip adults with job-specific occupational skills and inter-personal skills that will allow learners to enter into and attain some success in work world. The teaching-learning strategies for employability skills must be both guided and self-directed and involve the application of knowledge and skills.

Workforce employability is essential to turn structural change into an opportunity for all. Through innovative teaching methods in adult education, connections are to be established between study, personal development, and other activities 
that influence learners' ability to find employment and be successful in their chosen jobs. Personal skills such as communication, leadership, self-motivation, team-work, time management, listening, ability to work under pressure, making decisions, problem-solving, creativity, and so forth can be acquired, developed, and improved. Depending on the definition of ALE in the local context, the method employed for teaching may vary, and this may indirectly affect employability.

\section{Methodology}

This study was a qualitative study employing the narrative inquiry technique, literature review, and observation. These methods were used because they provided stories that were coherent and based on continuing personal experience concerning issues of employability in the countries under review. Moreover, studying and interpreting self-narratives helped the researchers to access the participant's identity and their contextual responses to employability and ALE teaching methods based on their cultural and social world (Lieblich, Tuval Mashiach, \& Zilber, 1998 p. 9). We think this is important for a holistic understanding of ALE teaching methods and employability in the countries. We selected a sample size of 5 individuals per country using multistage sampling techniques of purposive and convenience sampling techniques to ensure that the formal, non-formal, and informal context of ALE were represented in each country.

The instrument for data collection was a semi-structured interview containing items in three sections. The first, second, and third sections were used to collect participants' personal information, their employment and skills details, and their knowledge of ALE teaching methods, respectively. The results of the interview were presented in a narrative form and interpreted by applying content analysis. Categories are determined after initial documentation of the stories in relation to the research questions and personal experiences of participants. The findings were discussed based on categories of the research questions.

\section{Data analysis}

\section{ALE practice and employment in Nigeria}

ALE in Nigeria has its basis in the indigenous system of education, where children, youth, and adults have varying levels of knowledge, skills, and values to acquire. With the advent of Islam, Christianity, and colonisation, the indigenous system of education became silent while the Western education model took over. Due to high rate of non-literacy then, we had formal adult education, which started with acquiring the basic 3Rs. Gradually, the obsession with knowledge, skills, and 
development required people to update their knowledge and skills, so we had innovative programmes in ALE. From observation, we can group non-formal ALE programmes recognised and practised in Nigeria as:

1. Literacy: This includes basic adult literacy and post literacy.

2. Vocational: This includes workers' education, industrial training, extension education (health and agriculture), and apprenticeships.

3. Continuing education: This includes programmes related to remedial education, extra-mural classes, tertiary-level part-time, sandwich, and distance learning.

4. Civic oriented: This includes programmes related to citizenship, rural education, health education, environmental education, political education, women's education, retirement education, and nomadic education.

The country can be considered to practice formal ALE with academic programmes at various tertiary institutions. Although there are 82 federal, 124 state, and 103 private tertiary institutions in Nigeria, unemployment statistics do not seem to have improved significantly over the years. The government of Nigeria acknowledged this situation by providing schemes such as the Graduate Internship Scheme (GIS), the Nigerian Government's National Economic Empowerment and Development Strategy (NEEDS), and even the Student Industrial Work Experience Scheme (SIWES). Aside from these, there are also non-governmental organisations (NGOs) working on functional and entrepreneurship literacy to support the government in reducing the rate of unemployment. Statistics from the Nigerian National Bureau of Statistics (2016) show that the unemployment rate increased from 21.1 per cent in 2010 to 29.2 per cent in 2015 - this is disheartening. It is important to note that the method used for teaching is integral to employability skills because it ensures that learners get the soft skills and hard skills expected by employers or would-be employers. Hence, adults should not be taught with conventional methods, which often influence ideas and the curriculum. The methods used for teaching adults at the formal, informal, and non-formal levels of ALE have not had an impact in the labour market, as we have seen in the statistics of countries such as Nigeria.

The conventional teaching methods for ALE in Nigeria can be seen from the different types of programmes regarded as ALE. Some scholars recognised methods such as lecture/talk-chalk/telling; discussion; assignment/project/ written work; simulation/demonstration; seminar and workshop (Okenimkpe, 2003, p. 181; Bakare, 2010,pp. 141-144; Zuofa \& Olori, 2015, p. 1134), which are common for the civic-oriented and vocational adult education programmes. For the continuing adult education programmes, we find a heavy reliance on the lecture method, 
although it is not considered ideal for adult learners. For literacy, Okediran in Ihejirika (2013, p. 134) and the National Commission for Mass Literacy, Adult and Non-Formal Education (2008, p. 16) identified a one-on-one instructional approach (referred to in the country as 'each-one-teach-one'), Participatory Rural Appraisal (PRA), Regenerated Freirean Literacy through Empowering Community (REFLECT), and basic literacy by radio.

These commonly used methods have their benefits, but they also have disadvantages in terms of andragogy principles, because they do not enhance employability skills. For instance, the lecture, project, basic literacy by radio, and seminar formats are often rigid, not allowing the experience of adult learners to come into play. Ojokheta (2007) also disapproved of REFLECT, because his study revealed that when basic literacy learners are allowed to freely discuss the situation they live in to determine their problems, they get carried away and may not be interested in continuing with the learning activity. This may also be applicable to PRA, because both approaches have a way of raising consciousness in learners.

In order to establish teaching methods that are self-directed, active, experiential, collaborative, and narrative, all of which can enhance employability, it may be necessary to exploit traditional means of transmitting knowledge that will make maximum use of learners' experience and participation.

\section{ALE practice and employment in India}

In India, there have been conceptual changes in ALE (Shah, 2010, p. 80) from basic literacy, civic literacy, functional literacy, and developmental literacy to critical literacy, that is, moving towards critical thinking empowering learners to ask questions, seek information, take decisions, have equal access to education, health, livelihood, and all public institutions, participate in shaping their realities, create knowledge, participate in the workforce with improved skills, exercise agency fearlessly, and as a consequence, deepen democracy. At the tertiary level, India has 46 central universities, 358 state universities, 123 deemed universities, and 266 private universities. There is recognition that formal education alone cannot provide enough to improve citizens' potential to be employed in the country's economic sector. Consideration is still being given to ALE, as seen in the efforts of the government and international organisations.

For instance, there is the Skill Development Initiative Scheme (SDIS), which provides early school leavers and workers, especially in an unorganised sector, with employable skills. Only about 2.5 million vocational training seats are available in the country, whereas about 12.8 million persons enter the labour market every year (Directorate General of Training, no date). Even out of the training 
places, very few are available for early school dropouts. This signifies that a large number of school dropouts do not have access to skill development for improving their employability. There is also the Saakshar Bharat Mission, whose aim is to promote and strengthen adult learning with basic literacy, covering vocational education and skill development, applied science, and sports (UNESCO, no date). Due to its approach, Saakshar Bharat is described as a 'people's programme', with the government acting as facilitator and resource provider, but working closely with local communities to tailor the programme to their needs. India also has programmes such as SWABHIMAAN and DIKSHA that provide functional literacy classes to non-literate adults over a period in both rural and urban areas. Under these programmes 69,681 adults have been made literate (Rotary India Literacy Mission, no date).

With all these efforts, the number of unemployed persons in India went from 5.10 million in 1971 to 46.80 million in 2013 and to 48.26 million in 2014 (Trading Economics, no date). Fortunately, the unemployment rate decreased by half from 9.5 per cent in August 2016 to 4.8 per cent in February 2017 (India Express, 2017). It has been predicted by the International Labour Organisation that the number of unemployed people will increase from 17.7 million in 2016 to 18 million in 2018, even though the country's unemployment rate is expected to go down from 3.5 per cent to 3.4 per cent in 2017 (The Hindu, 2017). This reflects the need to develop entrepreneurs instead of employees, a literate and trained workforce equipped with the right set of hard and soft skills. For this purpose, acquiring employable skills is a must, and education adds to it. To ensure these, teaching methods are important, and according to Mohanty (2007, pp. 41-45), there are various teaching-learning approaches being practiced in India. Literacy methods being used include the traditional method, the alphabetic method, the word method, the letter method, the each-one-teach-one method, the Lauback method, and analytical and synthetic methods. For improving adults' professional and social related skills, demonstration, exposition, role-playing, discussion, group work, and simulation exercises are used.

In spite of using these methods, most learners are unable to acquire employability skills. Therefore, there is a need for adult educators who believe in the role of the facilitator and who constantly link adult learners' vast life experience to the learning material. For this purpose, innovative methods and techniques have to be identified within the community resources that can work equally well in formal, non-formal, and informal settings and develop employability skills. 


\section{Narratives}

The stories in this section are divided based on the ALE context the participants are presently involved in. The formal ALE context represents regular programmes of tertiary educational institutions; the non-formal ALE context is for those in professional extramural training development programmes; the informal ALE context is for those not enrolled in formal or non-formal training but learning within their immediate environment.

\section{Formal context}

Ahmed, a twenty-year-old Nigerian undergraduate studying full time for a B.A. in Political Science, has been able to develop writing, listening, self-motivation, and communication skills through his relationship with and observations of friends and family. He would love to develop more skills such as ICT, leadership, teamwork, and creativity skills, or the ability to work under pressure. He acknowledged that the lecture method, which is the main form of instruction in his tertiary institution, cannot help him achieve his desired skills, because it only helps him to know more about his career, not necessarily to fetch him a job upon graduation. This method does not accommodate learner's participation and contribution, because it is teacher- and content-centred. In learning the desired employability skills, Ahmed prefers doing a practicum. The use of drama and storytelling can be regarded as innovative because it will encourage students' participation and develop teamwork spirit, confidence, and courage. According to Ahmed, lecturers should act more like facilitators and guides to ensure the learning points are emphasised with these methods.

Folake, a thirty-year-old Nigerian in a M.Sc. Forensic Accounting programme, was once in formal employment. Hence, she has communication, creativity, ICT, and presentation skills, most of which she learnt through informal social interactions with people. She constantly upgrades her skills while on the job by reading professional books. Her desire to upgrade her employability status and skills motivated her to enrol in postgraduate studies, and she had to quit her job to manage her studies and family life. She wants to learn more about entrepreneurship skills to enhance her employability, but the straight lecture method often used in her institution does not allow for this. She stated that the instructors often believe that learners learn more when being lectured, but this method achieves nothing because it does not give room for interaction. She said that there should be a teaching method based on theories and practice, ensuring that students participate. Such methods should involve internships, demonstration, and simulation. She 
stated that sometimes there should be jokes complimenting the lecture method to arouse the interest of learners and engage their experience.

Darshita, a twenty-three-year-old pursuing a B.Eng., identified skills as visioning, decision making, working under pressure, problem solving, leadership and decision-making, and team building. She mostly acquires skills when she finds upcoming opportunities and new challenges. The motivating factors for updating skills are the targets, achievements, her passion for learning, and her curiosity to find new patterns. The source of skill update is interaction, e-learning, and reading. By constantly updating skills, whenever she sees new programming problems, she feels more confident in making programming codes. She is apt to learn every new skill, which rejuvenates her passion. In classes, her teachers use explanation through examples. Their delivery of slides is insufficient to satisfy learners' interest, curiosity, and expectations. Instead, Darshita said they should use case studies of the delivered topics and create an environment for free and creative expression of thoughts to make new employable skills achievable. Participatory and experiential learning approaches should be used.

Shaila is a twenty-two-year-old Indian studying for a master's degree in rural development. When she was counselled regarding post-graduate courses, she did not expect the course to equip her with employability skills. She is a commerce graduate with interpersonal skills, computing skills, writing and listening skills, innovative and creative skills, but lacks confidence and good decision-making practices. She is keen to learn and adapt to her environment by updating her knowledge and required skills. The source of learning is her teachers, peers, and relatives. In the post-graduate classes, she is experiencing a much better learning environment. The teaching methods used are discussion, participatory approach, role-playing, and projects, which give ample opportunity for free expression of thoughts using her experiences. Now she is in her second year and has developed managerial, leadership, and problem-solving skills. Her programme allows for flexibility, which allows her to decide what, when, and how she would like to learn in classes. Her teachers make use of movies, documentaries, cultural performances, and real-life incidents to simplify the course content and relate to her routine experiences. Therefore, joyful and meaningful learning takes place, which ensures the development of employable and transferable skills.

\section{Non-formal context}

Chineye is a thirty-nine-year-old Nigerian entrepreneur. She learnt fashion design through an apprenticeship after her secondary school education and became her own boss fifteen years ago. She has skills such as the ability to work under pressure, 
communication, leadership, time-management, creativity skills, among others. She acquired these skills during her apprenticeship training, but she constantly updates them to ensure that her customers are satisfied, to remain versatile in her career, and also to make more money. Usually when there are new styles in vogue, she will go to her trainer to learn about it, but subsequently she learns from videos, magazines, and the mass media in general. Updating her skills is beneficial, because she noted that her customers have increased by 50 per cent, and she is able to constantly satisfy them, she has more apprentices, and she keeps abreast with trends in the fashion world. She desires to learn more skills, such as suit-making and effective use of ICT, in order to expand her business and employment territories. She hopes to acquire these skills with support from and interaction with her colleagues, and demonstration will be the best method to help her achieve them. She finds demonstrations of cloth making on ICT platforms to be an innovative teaching method, but she may face challenges, such as being distracted by customers and neighbours, but this can be alleviated by learning outside her business premises to ensure that distractions from known persons do not happen.

Osaze is a thirty-five-year-old Nigerian, a basic literacy learner, and an automobile mechanic. He is self-employed and started his job as a mechanic after completing an apprenticeship at the age of nineteen. He was able to develop communication, creativity, and problem-solving skills. He was motivated to enrol at a basic literacy centre to develop better communication, reading, writing, and calculation skills to enhance his work. He was also motivated because he sometimes felt intimidated by his apprentices, who are secondary school students or dropouts. The method used often can be regarded as participatory, but it seems more like an active lecture method, which is limited because it does not encourage learners to teach other learners. A better teaching method that can use the experiences of the learners would be one involving indigenous arts such as music, film, drama, and stories. According to Osaze, this can be indigenous in nature, but it can also be misused as mere fun by learners. Therefore, he advised that the facilitators at the centres should be guided properly on the purpose of using these arts.

Swati is an Indian, a science graduate, and a forty-two-year-old beautician. Initially, she worked as a schoolteacher and then, at the age of twenty-eight, began a beauty parlour in a small room in her house. Her communication, creativity, and problem-solving skills motivated her to do something to match her skills, and she started the parlour and did a diploma course. Now, after fourteen years, her parlour is housed in a separate building. She has trained about 200 persons. She has also been a trainer in government schemes like swarozgar yojana and pradhanmantri kaushal vikas yojana to empower girls. Client requests and the 
variation in clients' behaviour motivate her to frequently update her skills. The challenge in her job is to understand the mind-set of the client to satisfy them with the services they demand and expect. The sources she uses to update her skills are seminars, workshops, training programmes by beauty experts, visiting other parlours, and the Internet. She stated that when seminars, workshops, demonstration, discussion, and lecture are used, there is no room for hands-on experience for participants. With constant update of creativity, communication and listening skills, she can remain successful and well prepared in advance to cater to the needs of clients.

Rajendra is a forty-year-old Indian farmer, who over time has acquired new knowledge and skills related to agriculture to keep him abreast of the new technology in agriculture; to overcome problems arising from unexpected weather conditions; and to maintain the fertility of the soil. He has gained a lot of information regarding good farming from his ancestors, peers and the songs, stories, and proverbs based on agricultural activities. He visits agricultural research centres to meet scientists and to attend fairs and exhibitions. At the fairs, lectures and discussions are organised by experts. In between lectures, current agricultural issues and concerns are conveyed through folk songs and cultural performances. Five years ago, he was an illiterate and he could only learn whatever information was communicated orally. Being dependent on others for reading, writing, and calculation made him feel bad. He decided to be independent by becoming literate so that he can also make use of all the sources of information: newsletters, pamphlets, magazines, newspapers, and e-learning. He joined adult literacy classes and is now a role model in his village by being in touch with all kinds of relevant information to get the best farming outcomes. He can be said to have acquired 40 per cent transferable skills.

\section{Informal context}

Ekaette is a forty-year-old Nigerian cloth seller and a primary school dropout who has been employed since the age of 26 after completing an apprenticeship. Presently, she is not on any specific training to enhance her employability, but she does have skills such as communicating in her indigenous language, decision-making, and problem solving to retain her customers and to keep abreast of trends in the cloth-trading industry. She developed these skills informally on a regular basis through observations, conversations, and relationships with customers. To enhance her communication with all types of customers, she desires to improve her communication skills in English language and her stocktaking ability. She has not enrolled in basic literacy class because there will be no one left to sell her stocks. 
She desires to continue learning these skills from her customers, neighbours, and family members. She stated that she could learn these skills through proverbs, storytelling, and practice.

Ragini is a thirty-five-year-old Indian housewife who is also a tailor (she sews at home). She keeps pace with changing trends through informal interactions with customers. At the age of fifteen, she learnt tailoring skills from her mother, and at age twenty-three, she began to sew professionally. She is good at visioning, decision-making, creativity, and time management but cannot update her tailoring skills frequently because of family responsibilities and limited exposure. The only opportunities to learn are her observations at parties or other social functions, so she depends solely on customers to bring their designs while she sews to meet their satisfaction. She stated that she is not really interested in learning new tailoring skills, but she wants to be able to manage her time well so she can finish her work fast and meet her financial needs. She believes this can be learnt through simulated practices and experiential learning at capacity-building events.

\section{Discussion of findings}

Based on the narratives and existing literatures above, the following were deduced in line with the research questions.

\section{What is the employment status and ALE practice in the countries?}

Even though Nigeria and India are on different continents, they are both developing countries having a common problem of an increased unemployment rate, although India seems to have a lower rate in relation to their population than Nigeria. In both countries, university students mentioned that the educational programmes they attended did not adequately develop skills relevant for employability - which could be one reason for the low rate of employment in the two countries. Hence, ALE is available in both countries with the view of solving this problem. ALE has a similar history in the two countries, starting out with basic literacy, but it seems to have more recognition by the government of India than that of Nigeria. Although ALE is supported by NGOs in both countries, NGOs in India create more opportunities for adult learners and promote learning through folk songs, arts, local knowledge, experience exchange, and the like. The practice of ALE in Nigeria can be regarded to be in line with functional literacy while that of India is for critical literacy. In addition, of the persons that were interviewed for this study, one Indian can be said to be above average in terms of their employability skills; two Nigerians and two Indians are average; three Nigerians and 
two Indians are below average. The participants were aware of their educational needs, hence, they engage in at least one context of ALE. They identified a lack of innovative teaching methods in formal and non-formal contexts of ALE practice.

\section{Which traditional ALE teaching methods are used in the two countries?}

The programmes related to preparation for the job market were not effective, especially in Nigeria. This is because of the use of traditional teaching methods, which are content- and teacher-centred. These methods include straight lecturing, identified only by Nigerians in formal ALE; active lecturing and personal e-learning was identified in equal proportion by the two countries; discussion is more used in India than in Nigeria; role-play and seminars were identified by Indians only. Furthermore, those working in the business sector have more opportunities for professional development through participation in online and on-the-job trainings, but they also identified the lack of a blended approach combining e-learning and face-to-face exchanges with colleagues. Those employed in low-paying jobs work on skills relevant for employability through spontaneous informal, self-directed learning.

\section{Which innovative ALE teaching methods can be used in the countries for employability?}

All participants expressed their need for participative and continuous educational programmes for renewing existing skills and gaining new professional/ employability skills. They regarded themselves as experiential learners who identified the exchange of experience and practice, blended learning, and learning through arts and humour as main elements of innovative teaching-learning approaches relevant to ALE. Specifically, practicums/internships and e-learning were identified as innovative methods by Nigerians only; the use of arts (stories, film, drama, documentary, music, cultural performance) were recognised as new and innovative more by Nigerians than by Indians; whereas demonstration and simulation were identified in equal proportion by participants in both countries. With these innovative methods, they said that they would have better employability skills.

\section{Conclusion}

The results of the study undoubtedly show that innovative teaching methods are linked to employability in India and Nigeria. The concentration on the use of traditional ALE teaching method in all ALE contexts is a direct and indirect reason 
for the low employment status in the countries. Therefore, it is recommended that to ensure improved employability, ALE educators should observe and learn how to improve teaching with innovative methods taking into account the transitions and overlap between formal, non-formal, and informal ALE contexts, as depicted in Figure 1.

Figure1: Innovative ALE teaching methods for employability.

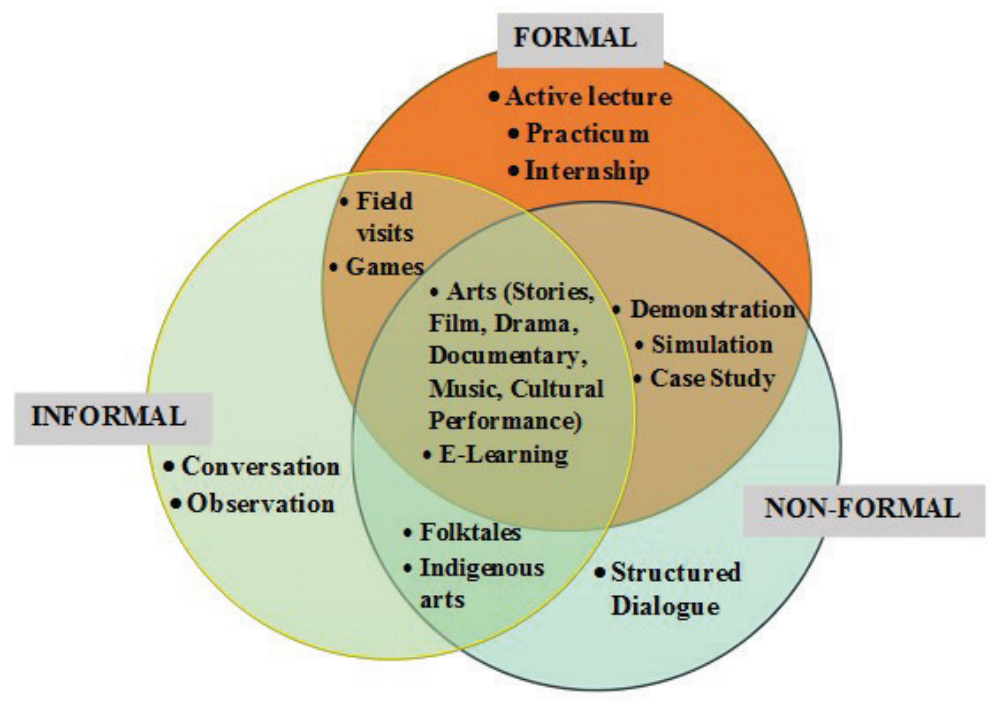

Source: Authors adapted from CW2, 2017 Wurzburg Winter School

The figure shows that there are some methods, such as arts and e-learning, that should be used across all ALE contexts; others, such as demonstration, simulation, and case studies, should be used for both formal and non-formal ALE contexts, whereas active lectures, practicums, and internships should be used in formal ALE alone. These methods can enhance employability because they comply with andragogy principles. Therefore, they can help learners develop skills such as writing, listening, self-motivation, teamwork, visioning, communication, self-confidence, decision-making, presentation, entrepreneurship, leadership, ICT, creativity/innovative, and presentation, among others. 


\section{References}

Bakare, Tewo: "Teaching Principles and Methods in Adult Education". In: Jegede, 'Supo (ed.): Adult Education Series 1. Editex Publishers Limited: Lagos 2010, pp. 128-150.

Boden, Rebecca / Nedeva, Maria: "Employing discourse. Universities and graduate 'employability"'. Journal of Education Policy 25(1), 2010, pp. 37-54, retrieved from DOI: 10.1080/02680930903349489.

Brown, Douglas: Teaching by Principles. An Interactive Approach to Language Pedagogy 2nd edition. Longman: New York 2001.

Directorate General of Training: Skill Development Initiative Scheme (SDIS), no date, retrieved 11.05.2017 from http://www.dget.nic.in/content/innerpage/ introduction-sdis.php.

Ihejirika, J. C: "A pre-view of government efforts in promoting mass literacy in Nigeria. Lessons from adult education historical research". Journal of Education and Practice 4(4), 2013, pp. 132-136, retrieved from http://www.iiste.org/ Journals/index.php/JEP/article/download/4527/4595.

India Express: "India's unemployment rate sees sharp decline". India Express, 05.03.2017, retrieved 10.05.2017 from http://indianexpress.com/article/busi ness/economy/indias-unemployment-rate-sees-sharp-decline-report-4555331/

Jha, Banhi / Goswami, Vandana / Surana, Ajay: "Skill development through nonformal education. An imperative for national development in India". IOSR Journal of Humanities and Social Science 20(2), 2013, pp. 26-30, retrieved on 11.05.2017 from iosrjournals.org/iosr-jhss/papers/Vol20-issue2/Version-4/ D020242630.pdf

Knowles, Malcolm / Holton, Elwood / Swanson, Richard: The Adult Learner: The Definitive Classic in Adult Education and Human Resource Development. Elsevier: San Diego 2005.

Lieblich, Amia / Tuval-Mashiach, Rivka / Zilber, Tamar: Narative Research. Reading, Analysis and Interpretation. Sage Publications: Thousands Oaks 1998.

Mohanty, Jagannath: Adult and Non-Formal Education. Deep and Deep: New Delhi 2007.

National Bureau of Statistics: Unemployment/Underemployment: 4th Quarter Report. National Bureau of Statistics: Abuja 2016.

National Commission for Mass Literacy, Adult and Non-Formal Education: The Development and State-of-the-Art of Adult Learning and Education (ALE): National Report of Nigeria. NMEC: Abuja 2008, retrieved 10.1.2017 from http://www.uil.unesco.org/fileadmin/multimedia/uil/confintea/pdf/National_ Reports/Africa/Africa/Nigeria.pdf. 
Ojokheta, Kester: "Paulo Freire's literacy teaching methodology. Application and implications of the methodology in basic literacy classes in Ibadan, Oyo State, Nigeria". Journal AED-Adult Education and Development 69, 2007, retrieved 10.01.2016fromhttp://www.dvv-international.de/adult-education-and-develop ment/editions/aed-692007/10th-anniversary-of-paulo-freirersquos-death/ paulo-freirersquos-literacy-teaching-methodology/.

Okenimkpe, Michael: Adult Education Teaching Methods: Principles, Procedures \& Techniques. University of Lagos Press: Lagos 2003.

Rotary India Literacy Mission: Adult literacy. RILM website, no date, retrieved 10.05.2017 from http://www.rotaryteach.org/adult_literacy.php.

Shah, S. Y.: "Teaching and training in adult and lifelong learning in India. Need for professionalisation". Indian Journal of Adult Education 71(4), 2010, p. 80, retrieved 23.4.2016 from http://www.iaea-india.org/journal/oct-dec10/sy-shah. html.

Trading Economics: India Unemployed Persons. Trading Economics website, no date, retrieved 10.05.2017 from http://www.tradingeconomics.com/india/ unemployed-persons.

The Hindu: "More people to be jobless in India: ILO Special Correspondents". The Hindu, 13.01.2017, retrieved 27.06.2017 from http://www.thehindu.com/busin ess/economy/more-people-to-be-jobless-in-india-ILO/article17036623.ece.

United Nations Education, Science and Cultural Organisation: Saakshar Bharat Mission. UNESCO, no date, retrieved 11.05.2017 from http://www.unesco.org/ uil/litbase $/$ ?menu=9\&programmeme $=132$.

UNESCO Institute of Lifelong Learning: 3rd Global Report on Adult Learning and Education. UNESCO Institute of Lifelong Learning: Hamburg 2016.

Wadhwa, Shalini: Theory and Principles of Adult Education. Sarup \& Sons: New Delhi 2000.

Zuofa, Comfort / Olori, Christian: "Appraising adult teaching methods in Nigeria. Analysis of the effect of some teaching methods on adult learners". American Journal of Educational Research 3(9), 2015, pp. 1133-1137, retrieved 10.01.2017 from DOI 10.12691/education-3-9-10. 


\section{Authors}

Azeez Babatunde Adebakin, doctoral student and faculty member, Department of Educational Management, Obafemi Awolowo University, Ile-Ife, Nigeria. E-mail: adebakinazeez@yahoo.com

Elizabeth Aanuoluwapo Ajayi, doctoral student in adult and non-formal education, University of Benin, Nigeria. E-mail: lizdara@yahoo.com

Zahia Alhallak, doctoral student, University of Florence, Italy. E-mail: zahia.alhallak@unifi.it

Nitish Anand, M.Phil. student, Department of Adult Continuing Education and Extension, University of Delhi, New Delhi, India. E-mail: nitishanand2891@ gmail.com

Hyejin Bak, doctoral student, Department of LifeLong Learning, College of Education, Seoul National University, South Korea. E-mail: hb208@snu.ac.kr

Geetanjali Baswani, doctoral student in adult education, Dr. Harisingh Gour University, India. E-mail: daisiesgeeta@gmail.com

Vanna Boffo, Ph.D, associate professor of general pedagogy, Department of Education and Psychology, University of Florence, Italy. E-mail: vanna.boffo@unifi.it

Lisa Breitschwerdt, doctoral student and research fellow in adult and continuing education, Julius-Maximilian University of Würzburg, Germany. E-mail: lisa.breitschwerdt@uni-wuerzburg.de

Fabio Camilloni, doctoral student in pedagogical, educational and instructional science, University of Padua, Italy. E-mail: fabio.camilloni@phd.unipd.it

Janiery da Silva Castro, doctoral student, University of Florence, Italy and fellow of CAPES Foundation, Ministry of Education, Brazil. E-mail: janiery.dasilvacastro@unifi.it.

Arunima Chauhan, doctoral student, Department of Adult and Continuing Education and Extension, Jamia Millia Islamia, New Delhi, India. E-mail: arunimachauhan18@gmail.com

Christin Cieslak, doctoral student in education, Free University of Brussels, Belgium.E-mail: christin.cieslak@googlemail.com

Vijay Kumar Dixit, PhD, university professor, Department of Adult and Continuing Education and Extension, University of Delhi, India. E-mail: vk_dixit31@ rediffmail.com

Regina Egetenmeyer, Dr. phil., university professor of adult and continuing education, Julius-Maximilian University of Würzburg, Germany. E-mail: regina. egetenmeyer@uni-wuerzburg.de 
Monica Fedeli, $\mathrm{PhD}$, university professor of teaching and learning methods in adult education, Università degli Studi di Padova, Italy.E-mail: monica.fedeli@ unipd.it

Jenny Fehrenbacher, doctoral student in education, Julius-Maximilian University of Würzburg, Germany. E-mail: jenny.fehrenbacher@uni-wuerzburg.de

Gaia Gioli, PhD, postdoc, University of Florence, Italy. E-mail:gaia.gioli@unifi.it

Paula Guimarães, $\mathrm{PhD}$, associate professor, Instituto de Educação, Universidade de Lisboa, Portugal. E-mail: pguimaraes@ie.ulisboa.pt

Robert Jjuuko, doctoral student, University of Groningen (Netherlands). E-mail: robert@adultslearnuganda.org

Nikola Koruga, doctoral student in adult education, Faculty of Philosophy, University of Belgrade, Serbia. E-mail: koruganikola.ae@gmail.com

Ashok Kumar, doctoral student, Department of Adult, Continuning Education \& Extension University of Delhi, New Delhi, India.E-mail: dr.ashokkumar2010@ gmail.com

Reinhard Lechner, doctoral student and research fellow in adult and continuing education, Professorship for Adult and Continuing Education, Julius-Maximilian University Würzburg, Germany. E-mail: reinhard.lechner@uni-wuerzburg.de

Kira Nierobisch, $\mathrm{PhD}$ in education, research fellow, Department of Adult Education and Vocational Education, University of Education Ludwigsburg, Germany.E-mail: nierobisch@ph-ludwigsburg.de

Bharti Praveen, doctoral student in education, Department of Adult Continuing Education and Extension, University of Delhi, India.E-mail: bharti.praveen09@ gmail.com

Mari Liis Räis, doctoral student in sociology, School of Governance, Law and Society, Tallinn University, Estonia.E-mail: mari.liis.rais@gmail.com

Rute Ricardo, doctoral student in education, University of Padua, Italy. E-mail: rutecristovaoricardo@phd.unipd.it

Jan Schiller, doctoral student in continuing education and lifelong learning, Helmut Schmidt University / University of the Federal Armed Forces Hamburg, Germany.E-mail: schiller@hsu-hh.de

Sabine Schmidt-Lauff, university professor, Professorship for Continuing Education and Lifelong Learning, Helmut Schmidt University / University of the Federal Armed Forces Hamburg, Germany. E-mail: schmidt-lauff@hsu-hh.de Vicheth Sen, doctoral student in educational studies, University of British Columbia, Vancouver, Canada.E-mail: vicheth.sen@alumni.ubc.ca

Sunita Sijwali, doctoral student, adult and continuing education and extension, Jamia Millia Islamia, New Delhi, India. E-mail: sunitasijwali16@gmail.com 
Leonardo Silveira, doctoral student, University of Lisbon, Portugal. E-mail: leotornel@gmail.com

Bolanle Simeon-Fayomi, $\mathrm{PhD}$, visiting senior lecturer/researcher, Professorship for Adult and Continuing Education, Julius-Maximillian University, Würzburg, Germany.E-mail: bola.simeon-fayomi@uni-wuerzburg.de

Shalini Singh, doctoral student, research fellow at the International Institute of Adult and Lifelong Education, India and guest researcher at Aarhus University, Denmark. E-mail: contactingshalinisingh@gmail.com

Shreelakshmi Subbaswamy, doctoral student, Department of Education, The Maharaja Sayajirao University of Baroda, India.E-mail: pakkishree92@gmail.com

Carlo Terzaroli, doctoral student, Department of Education and Psychology, University of Florence, Italy. E-mail: carlo.terzaroli@unifi.it

Concetta Tino, PhD, post-doc research fellow, University of Padua, Italy. E-mail: concetta.tino@unipd.it

Nicoletta Tomei, doctoral student in education, Univeristy of Florence, Italy E-mail: nicoletta.tomei@unifi.it

Ahmet Murat Yetkin, doctoral student, Faculty of Business Administration and Economics, University of Pecs, Hungary. E-mail: muratyetkin@gmail.com 
Regina Egetenmeyer and Monica Fedeli - 978-3-631-73704-0

Downloaded from PubFactory at 01/11/2019 10:08:46AM

via free access 


\section{Reviewers}

Thank you very much for supporting the editors of this volume in the review process.

Prof. Joellen Coryell, Texas State University, United States of America

Daniela Frison, PhD, University of Padua, Italy

Dr. Alexandra Iounnidou, German Institute for Adult Education

Prof. Henning Pätzold, University Koblenz-Landau, Germany

Prof. Amy Rose, Northern Illinois University, United States of America

Prof. Michael Schemmann, University of Cologne, Germany

Prof. Silke Schreiber-Barsch, University of Hamburg, Germany

Prof. Rabab Tamish, Bethlehem University, Palestine

Prof. Edward W. Taylor, Penn State University Harrisburg, United States of America

Prof. Elizabeth J. Tisdell, Penn State University Harrisburg, United States of America 